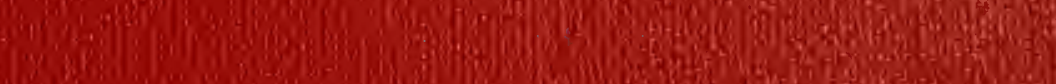
[6a

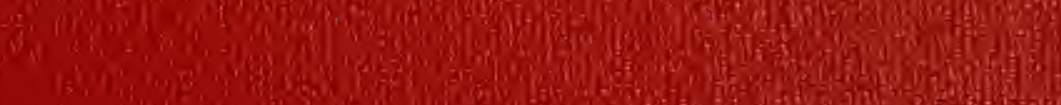
A. M. (1)

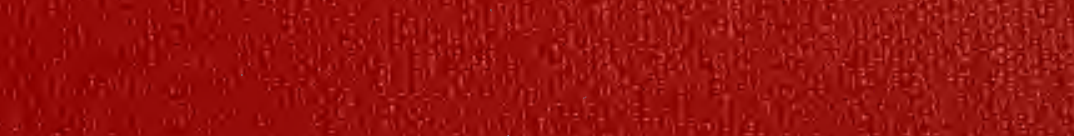
H. ton

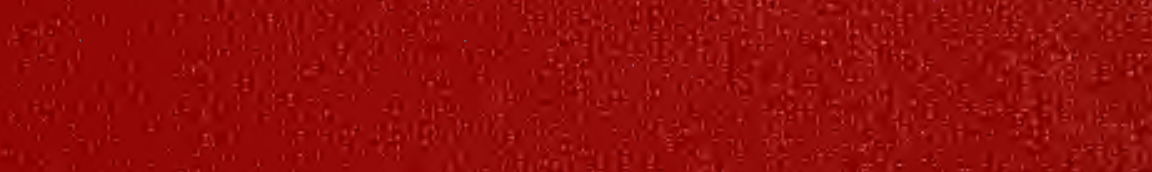

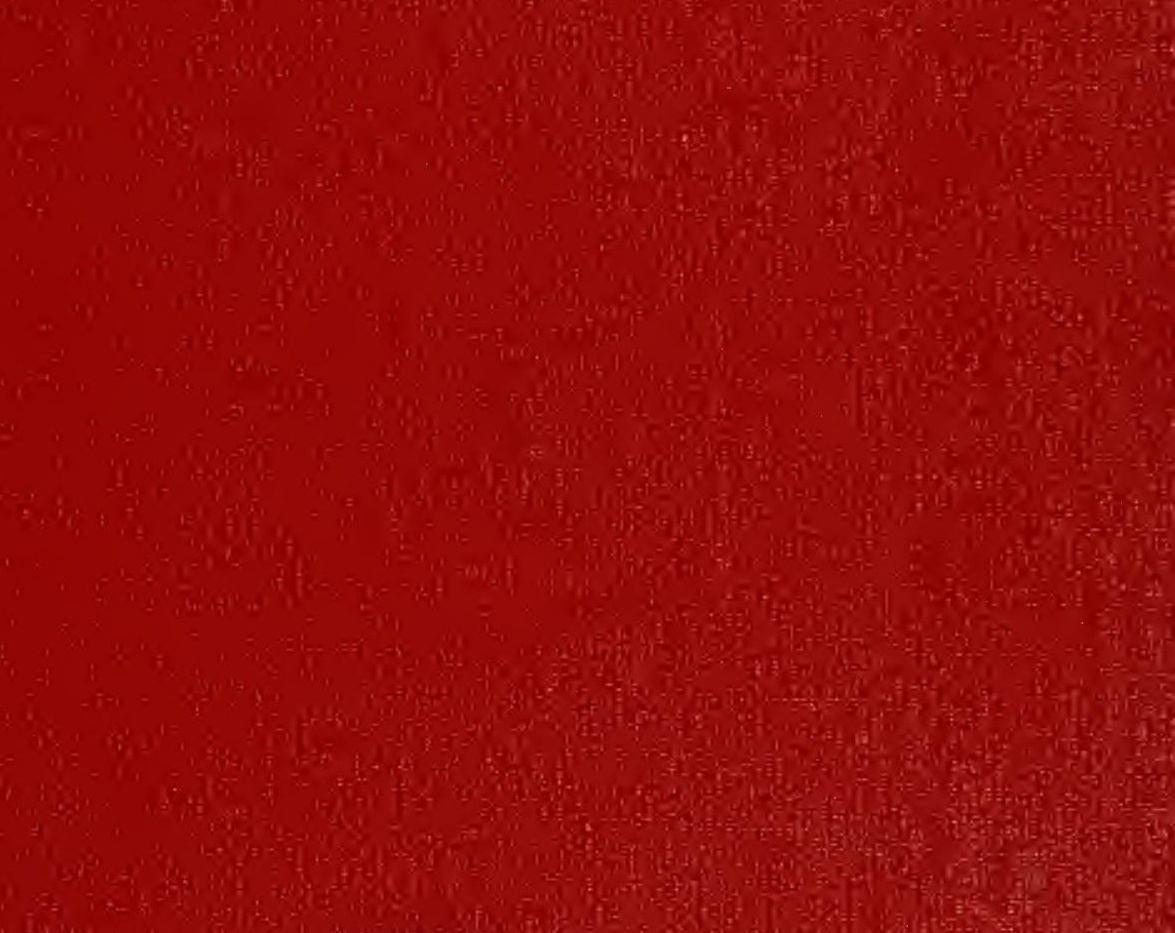

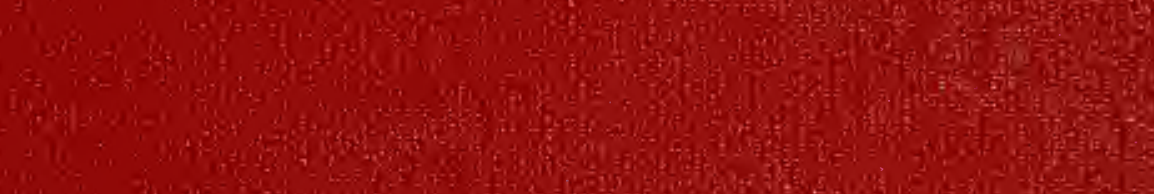
(1)

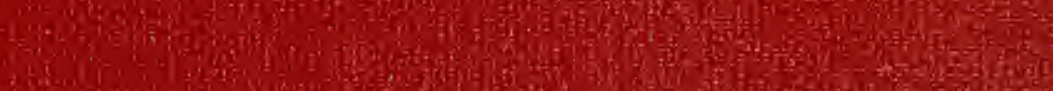
(2)

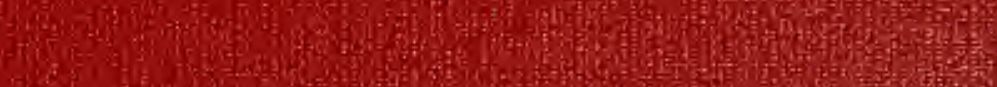
The

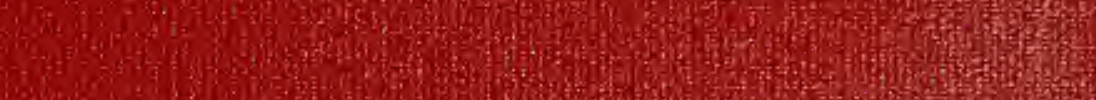

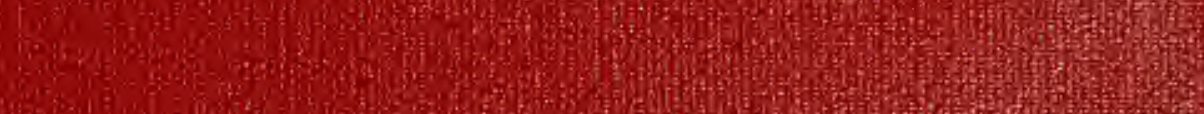
Q6. som 2. 


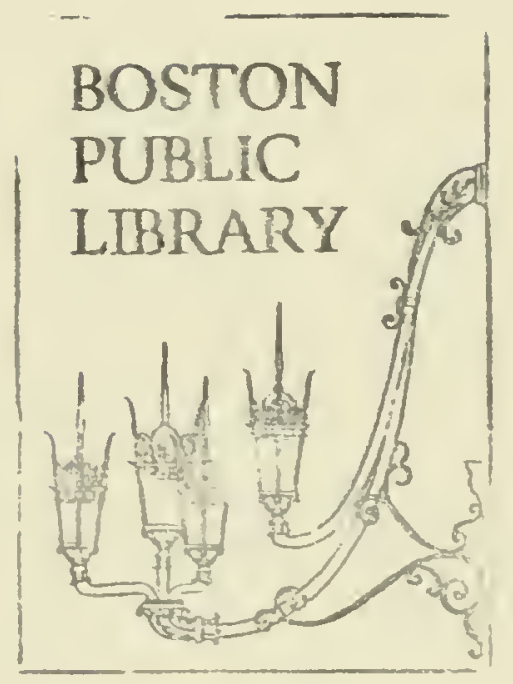





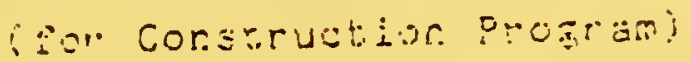

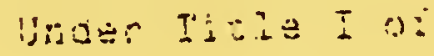

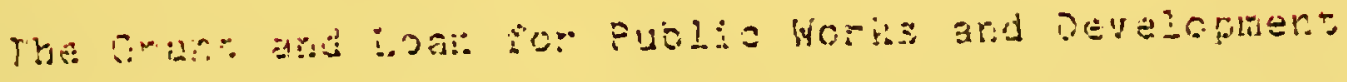

$$
\text { Facilitiss Frograt }
$$

$$
\begin{gathered}
\text { (Catratco } 10.12 .300) \\
\text { 10: }
\end{gathered}
$$

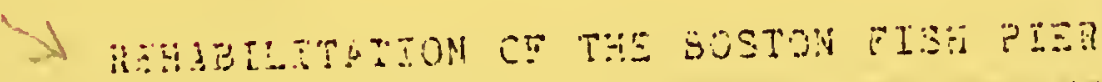

$$
\text { Sustitcad to the }
$$

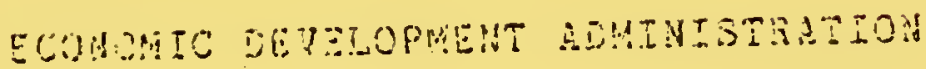

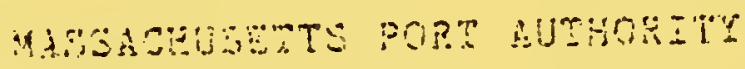

$$
\begin{aligned}
& \text { bavid it. Davis } \\
& \text { A.pis., } 1979
\end{aligned}
$$

Property of BOSTON REDEVELOPMENT AUTHORIT Library. 

APPLICATION FOR FEDERAL ASSISTANCE

$$
\text { (for Construction Program) }
$$

$$
\text { Under Title I of }
$$

The Grant and Loan for Public Works and Development

\author{
Facilities Program \\ (Catalog No. 11.300) \\ for \\ REHABILITATION OF THE BOSTON FISH PIER \\ Submitted to the \\ ECONOMIC DEVELOPMENT ADMINISTRATION \\ MASSACHUSETTS PORT AUTHORITY \\ David W. Davis \\ Apri1, 1979
}


John Corrigan, Regional Director

Economic Development Administration

Atlantic Regional office

600 Arch Street

Philadelphia, Pennsylvania 19106

Dear Mr. Corrigan:

I have enclosed an original and a copy of the Massachusetts Port Authority's application to the Economic Development Administration (form 101P) requesting a grant for Phase II of the rehabilitation of the Boston Fish Pier. Total Phase II costs are estimated at $\$ 6$ million of which $\$ 4.5$ million is requested in federal funds. The remaining $\$ 1,125,000$ will be provided by the Massachusetts Port Authority.

These funds will enable Massport to complete, as planned, the rehabilitation of the Boston Fish Pier begun last year with a grant from your agency. We anticipate the project creating 900 jobs in the fishing industry and more than 2800 by indirect impact. Your investment, and ours, will leverage more than $\$ 60$ million in the fishing and fishing support industries. Boston, given its excellent access to truck and air routes remains the ideal location for this redevelopment.

We appreciate your support in the past and look forward to working with you in the future as this project nears completion.

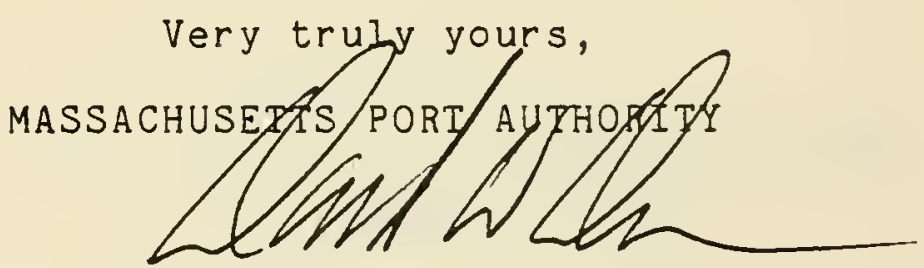

David W. Davis

Executive Director

DWD/dec 
Title Page

Transmittal Letter

Table of Contents

Summary

Letters of Support

Michael S. Dukakis, former Governor of Massachusetts Kevin H. White, Mayor of Boston

Joseph Moakley, Representative for Massachusetts

Frederick P. Salvucci, former Massachusetts Secretary of $\mathrm{Tr}$ ansportation

Frank $T$. Keefe, former Massachusetts Director of State Planning

Brian Dacey, Acting Director of Federal Relations for City of Boston

Francis M. Byrnes, President, F.E. Harding Company

Frank Foley, President, M.F. Foley Company

Russell Nagle, John Nagle Company

Hugh O'Rourke, Executive Secretary, Boston Fisheries Assoc.

Bill Stride, President, Turner Fisheries, Inc.

FORM ED 101-P Application for Federal Assistance

A-95 Review (Part 1 Section 22B)

Part II Attachments

Forms ED 501, 503, 612

\section{EXHIBITS}

4A. Need for Rehabilitation

4A. Attachments

1. Letter of Interest

43. Description of Project

4B. Attachments

1. Work Description 
1. Work Description

2: Resolve 1 1 - 1976 Acts and Resolves of the General Court of Massachusetts.

3. "The Fishing Industry in Massachusetts" report prepared for the Massachusetts

Port Authority, November, 1977.

IV-2 Employment Effect of Pier Rehabilitation.

IV-2 Attachments

1. Boston Fish Pier Employment Survey.

2. Letter from L. Nealon, President of Seafood Workers Union.

3. Massachusetts Port Authority Non-Discrimination Equal Opportunity and Affirmative Action Policy and Program.

IV-3 Statements of Overall Economic Development Programs Boston Plan

Boston Overall Economic Program

Metropolitan Area Planning Council's

Overall Economic Development Plan

Economic Development Plan for Massachusetts.

ADDENDUM

Project Managers

Fish Pier Budget 


\section{LETTERS OF SUPPORT}

Michael S. Dukakis, former Governor of Massachusetts

Kevin H. White, Mayor of Boston

John Joseph Moakley, Representative for Massachusetts

Frederick P. Salvucci, former Massachusetts Secretary of Transportation

Frank T. Keefe, former Massachusetts Director of State Planning

Brian Dacey, Acting Director of Federal Relations for City of Boston

Francis M. Byrnes, President, F. E. Harding Co.

Frank Foley, President, M. F. Foley Co.

Russell Nagle, John Nagle, Co.

Hugh O'Rourke, Executive Secretary, Boston Eisheries Association

Bill Stride, President, Turner Fisheries Inc. 

THE COMMONWEALTH OF MASSACHUSETTS

EXECUTIVE DEPARTMENT

STATE HOUSE - BOSTON 02133

CHAEL S. DUKAKIS

GOVERNOR

December 7, 1978

Mr. John Corrigan, Director

Economic Development Administration

Atlantic Regional office

600 Arch Street

Philadelphia, PA 19106

Dear Mr. Corrigan:

On behalf of the Commonwealth of Massachusetts, I would Iike to endorse the Massachusetts Port Authority's application for Title I funds to complete Phase II of the rehabilitation of the Boston Fish Pier. This request for funding is of utmost importance if this project is to be successfully completed.

The Boston Fish Pier is a vital link in the New England fishing industry. Fish prices for the ports of Gloucester and New Bedford are set every morning at the auction of the Boston Fish Pier. Over 20,783 thousand pounds were landed at the pier in Fiscal year 1978, an increase of 98 from the previous year. In the future, the proximity of the Boston Fish Pier to Logan International Airport is expected to be an advantage for Boston and Massachusetts as the export market for fish and fish products expands.

The provision of modernized and expanded quarters for the fishing industry will increase job opportunities and stinulate investment in fishing related industries. It is expected that the expansion wiIl create 820 long term jobs in the fishing industry and 2050 additional jobs in fishing support industries. Several firms, hearing of the rehabilitation, have already invested 1.9 million in new capital and are expecting to generate over $\$ 14$ million gross revenues during the first year and $\$ 23$ million annually after the third year.

The merits of this project are obvious. I urge the Economic Development Administration to approve this application and to allow Massport to complefe to this necessary and ambitious undertaking.

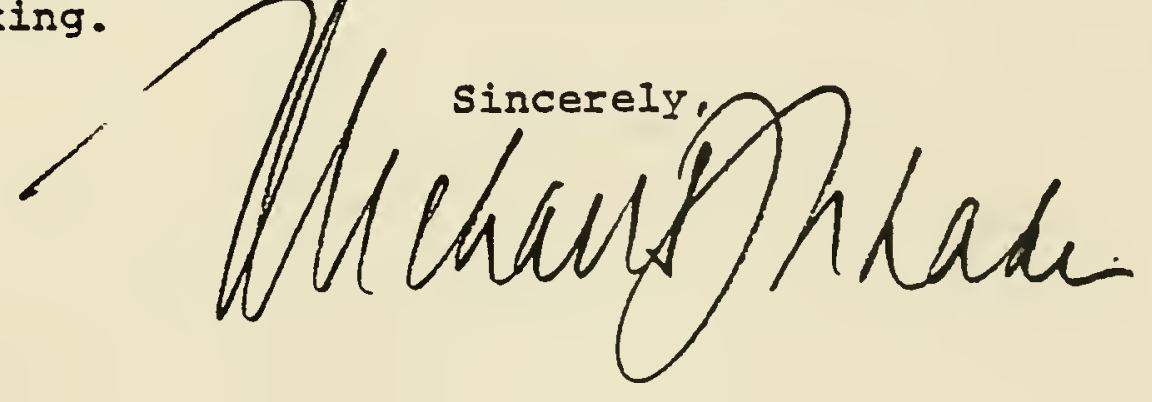





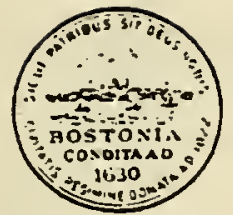

OFFICE OF THE MAYOR

CITY HALL.BOSTON

KEVIN H. WHITE

MAYOA

December 11, 1978

Mr. John Corrigan, Director

Economic Development Administration

Atlantic Regional Office

600 Arch Street

Philadelphia, PA 19106

Dear Mr. Corrigan:

The Economic Development Administration is considering an application for a $\$ 4.5$ millition grant by the Massachusetts Prot Authority. I understand these monies would be used to complete the rehabilitation of the Boston Fish Pier begun under the $\$ 2$ million EDA grant given to the Port Authority last fiscal year. The City of Boston supported the application last year and whole heartedly supports this year's application.

Rehabilitation of the Boston Fish Pier is a major project for the City, the state and the region. It would revitalize the fishing fleet thereby reinforcing ship repair activity at the city's nearby Boston Marine Industrial Park. In order to stabilize the present 1300 plus jobs at the fist pier and to insure the creation of some 3000 more (direct and indirect impact), rehabilitation of the fish pier must be completed.

The Fish Pier project is an important part of the Boston Plan. And, as its completion hinges on EDA funds, the city of Boston encourages the acceptance of this application..

Sincerely,

Kevin H. White

Mayor 

Congress of the annited States

百ouse of Zepresentatibes

2elasfington, 酒.C. 20515

December 12, 1978

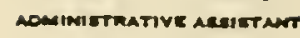

238 Cuncon Bullatns

(202) $225-1273$

ROGER KINEAVY Diotmict Manuace

1900C_JFK EutLoina Bostone. MAssucanserts 02203 (617) 223-57 is

Address reply to: Room $1900 \mathrm{C}$ John F. Kennedy Federal Butlding Boston, Kassachusetts 02203

Mr. John Corrigan, Director

Economic Development Administration

Atlantic Regional Office

600 Arch Street

Philadelphia, Pennsylvania 19106

Dear Mr. Corrigan:

I would like to thank the Economic Development Administration for its grant of $\$ 2$ million to the Massachusetts Port Authority to renovate the Boston Fish Pier. The funds were well-timed and well-received.

This grant as you are aware was the first of a two part project. The verbal commitment from the EDA was for \$2 million for FY 1978 and $\$ 4.5$ million provided FY 1979 . Construction for Phase I is expected to begin in the spring. Since the two phases of the project are so closely related it is important that Phase II begin as soon as possible.

This project is vital to the city, state and region, as well as to the local community. Rehabilitation of the Boston Fish Pier will create over 2,700 new jobs in a city that badly needs industrial jobs. Various individuals invested over $\$ 7.9$ million into capital equipment in the fishing industry, and are expecting revenues of approximately $\$ 14$ miliion this year and $\$ 22.8$ million the third year. I am sure that when the rehabilitation work is completed, even more interest in investing in the fishing industry will be generated.

The Boston fishing industry has always been located in the inner city. The supply of fresh fish is unloaded, auctioned and processed right on site. The Fish Pier serves regional, national and international markets. Boston's transportation network of highways, railroads and airways serves the present market well and would allow for significant expansion. 
Prospects are brightening for the fishing industry: The 200-mile limit and Public Law \#95-354 show legislative support for the industry. Your support is shown by your financing of Massport's previous application and other port related applications.

On behalf of my constituents, I thank you for helping to make this development possible.

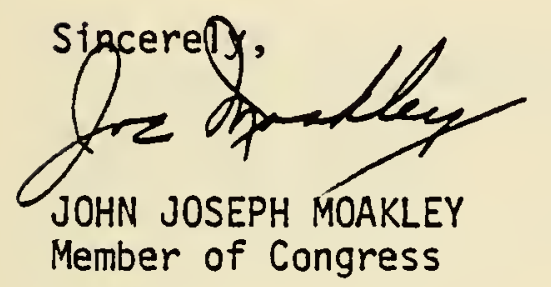





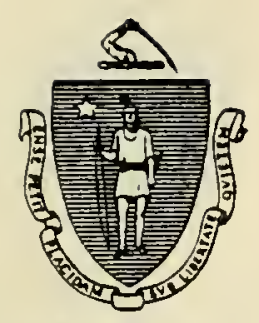

FREDERICK P. SALVUCCI SECRETARY
The Gommonwealth of Massachusetts

\author{
Esrcutive Cffice of Transportation de Gonstruction \\ One Ashbuxton Place \\ Boston. Mlassachusetts oros
}

December 6, 1978

Mr. John Corrigan, Director

Economic Development Administration

Atlantic Regional office

600 Arch Street

Philadelphia, PA 19106

Dear Mr. Corrigan

I applaud the Economic Development Administration for supporting the Massachusetts Port Authority's Title I application to renovate the Boston Fish Pier with its grant of $\$ 2$ million last fiscal year and encourage support for this year's application requesting $\$ 4.5$ million for Phase II of the project.

The completion of this renovation of the Fish Pier facilities is essential to accommodate growth and renewed interest in the fishing industry, spur red by the enactment of the 200-mile limit. The Executive Office of Transportation and Construction recognizes the benefits the increase in job opportunities and investment will bring to the Commonwealth's economy.

Massport has demonstrated its support for the fishing industry in this rehabilitation effort. I urge the Economic Development Administration to approve this application.

FPS : $m \times g$

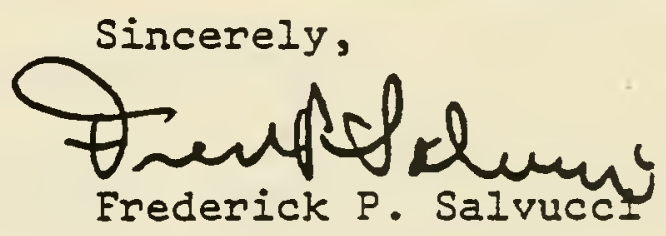



THE COMMONWEALTH OF MASSACHUSETTS

\author{
OFFICE OF STATE PLANNING \\ JOHN W. MCCORMACK BUILDING ROOM 2101 \\ ONE ASHBURTON PLACE
}

BOSTON. MASSACHUSETTS 02108

$1617) 727.5066$

IICHAEL S. DUKAKIS

GOVERNOR

FRANK T. KEEFE

DIRECTOR

December 19, 1978

John Corrigan, Director

Economic Development Administration

Atlantic Regional Office

600 Arch Street

Philadelphia, PA 19106

Dear Mr Corrigan:

On behalf of the Office of State Planning, I would like to express my support of Massport's Title I application for Phase II of the renovation of the Boston Fish Pier.

The fishing industry has received increased attention from industry and government since the passage of the 200-mile limit and Bill No. 95-354, which restricts first choice of U.S. fish to U.S. processors. In the next five to seven years, we expect the New England fishing industry to expand significantly. The renovation of the Boston Fish Pier will provide facilities for the fishing industry essential for growth in this vital sector of our economy.

The Office of State Planning supports continued progress on this project, so important to the Boston economy and to the economic well-being of the state as a whole.

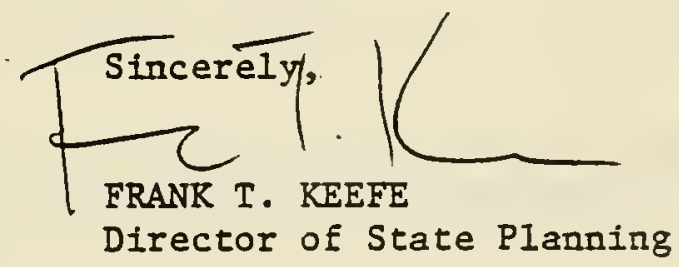


JOHN E. DREW

Director

7254224

December 11, 1978

Mr. John Corrigan, Director

Economic Development Administration

Atlantic Regional Office

600 Arch Street

Philadelphia, PA 19106

Dear Mr. Corrigan:

I am writing in support of Massport's application for funding Phase II of the rehabilitation of the Boston Fish Pier.

Rehabilitation of the fish pier, as an integral part of our waterfront redevelopment was an improtant section in Boston's major economic planning document. Waterfront redevelopment which would include fish pier rehabilitation is included in Boston's Comprehensive Economic Development Strategies (CEDS) Rrogram.

Boston has the potential for becoming the principle fish unloading, processing, and transporting center for New England. Its history as a major fishing port, its location in the regional transportation network and its proximity to Loan International Airport practically guarantee the Boston Fish Pier prominence in the industry. The 200-mile limit is expected to double fish landings within the next decade.

With renovated facilities at the pier, Boston fish processors can take advantage of this increased activity.

The renovation of the Boston Fish Pier is an important step toward revitalizing Boston's economy and job base. I commend the EDA's approval of Massport's first application for Phase I of this project and urge EDA's approval of this application to finish the project.

Sincereiy, 


\section{F. E. HAR DING COMPANY}

WHOLESALERS • SEA FOODS

TELEPHONE

LIberty 2-9533

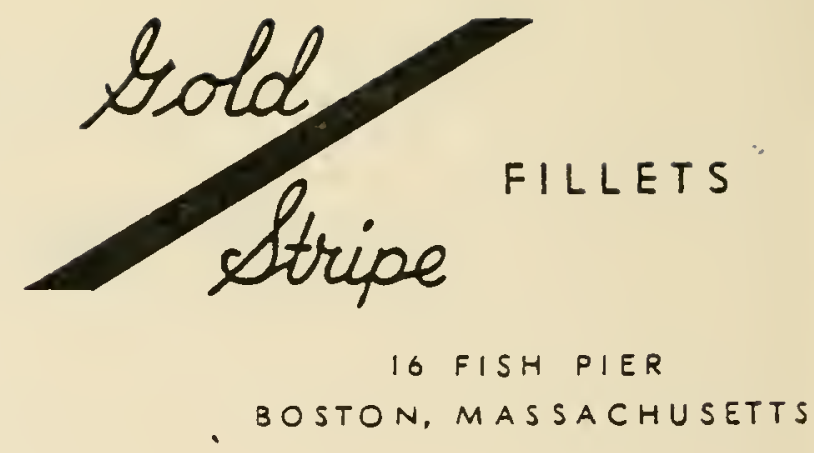

January 30, 1979

Mr. John Corrigan Director

Economic Development Administration

Atlantic Regional Office

600 Arch Street

Philadelphia, Pa. 19106

Dear Mr. Corrigan:

I am writing in support of Massport's application to the EDA to fund phase

II of the rehabilitation of Boston Fisheries.

The Fish Pier is now in a decadent and antiquated condition and without the aid of the EDA and MASSPORT, the Fish Pier dealers would be forced to close their doors. Since most of us are relatively small businesses, we do not have the capital to finance a rehabilitation project of approximately 9 million dollars. We applaud the $\mathrm{EDA}$ for financing Massport's first application for two million dollars, however, we do not see how the project can be completed unless this application for 4.5 million is also approved.

Boston has traditionally been the leading fishing port in Massachusetts. Beavy foreign fishing of cod and haddock and rumors of better facilities in other Massachusetts ports have eroded this position. Now that the 200-mile limit is in effect, fish processing plants will expand, providing job opportunities and belping the economy of Boston and the State of Massachusetts.

In closing, I cannot reiterate strongly enough the importance of the EDA's and Massport's Iinancial support in this project to rehabilitate the Fish Fier so that we can once again participate in the world market of fresh and frozen fish products. Without the help of this EDA monies, the Boston Fish Pler would surely collapse.

Very truly yours,

F. E. HARDING COMPANT<smiles>C=CCCCC</smiles><smiles></smiles>$] }$<smiles>C1=C[C@@H]2CC[C@@H]1C2</smiles>

Francis M. Byrnes, 


\section{F. FOLEY COMPANY}

\section{December 7, 1978}

Mr. John Corrigan, Director

Economic Development Administration

Atlantic Regional office

600 Arch Street

Philadelphia PA 19106

Dear Mr. Corrigan:

I own a fresh Iish processing plant in Dorchester, and even though I am not located on the pier I am concerned about the future of the fish pier. I have participated in the meetings being held among Massport staff, the architects and fish pier processors to make decisions about staff and use needs at the pier since September 1978, when the ilrst one was held.

Boston needs a rehabilitated fish pier. The facilities that exist now for fish processing, unloading and gurry handling are antiquated and inadequate for the growth that we expect in the fishing industry. The Boston Fish Pier, as the center for all fish processing activities for the city of Boston, is important for the Iivelihood of all seafood related industries in the city of Boston and the region.

The work that began under Massport FY 78 grant is only part of the project. I strongly urge the EDA to approve this application for $\$ 4.5$ million to complete this rehabilitation. The revitalization of Boston's and New England's fishing industries cannot be accomplished without the EDA's help.

Sincerely,

M. F. FOLEY COMPANY

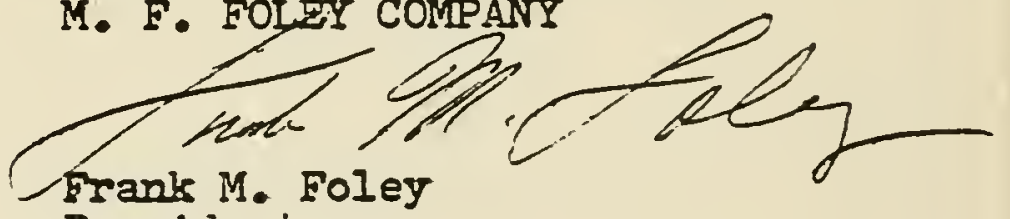

President

FMF/mtb 


\section{JOHN NAGLE CO.}

bolesde Distributors of Fresb and Frozen Fisb

Irst pin

205Tox. urse. cosso

February I, 1979

Mr. John Corrigan, Director

Economic Development Administration

Atlantic Reglonal office

600 Arch Street

Ph1ladelphia, PA 19106

Dear Mr. Corrigan:

I strongly urge the Economic Development Adminlstration to support Massport's application for Phase II rehabilstation of the Boston Fish Pier.

Prior to the establishment of the two hundred mile limit, Investment had begun, and today it is increasing. The Boston Fish Pler needs your support and the C1ty of Boston needs your support for the renovation of this property.

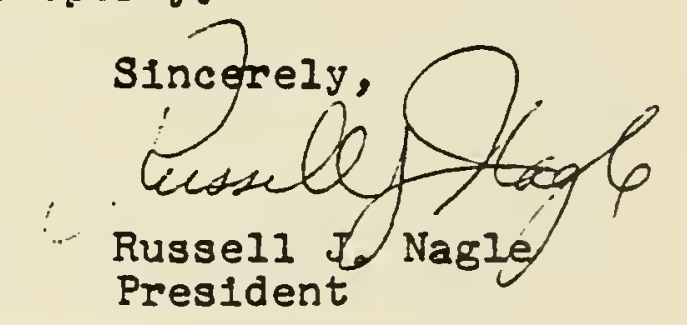

$\operatorname{RJN} /$ Jod 


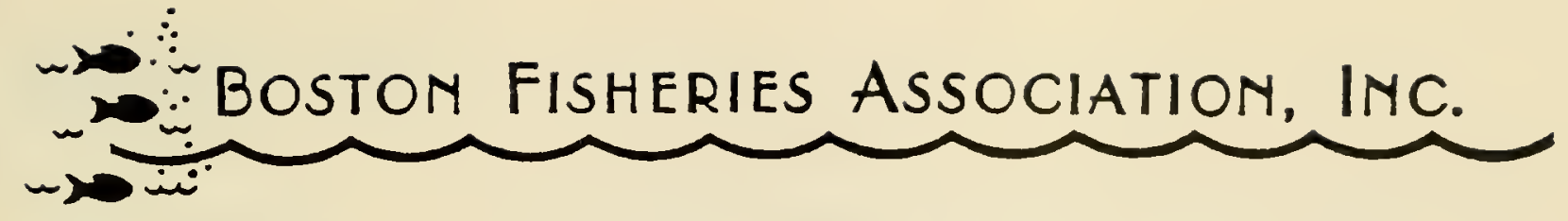

HUGH F. O'ROURKE

Excoutive Scerotory

253 NORTHERN AVENUE, FISH PIER, BOSTON, MASS. 02210

342.4688

January 10, 1979

Mr. Robert T. Hall, Assistant Secretary

Economic Development

U. S. Department of Commerce

Economic Levelopment Administration

5081 Main Commerce Bu1lding

I 4 th Street and Constitution Avenue, N. W.

Washington, D. C.

Lear Mr. Hall:

The cooperative effort and interest by the Massachusetts Port Authority, the Economic Development Administration, the Boston Fish Pier Tenants Group, and the Boston Fisheries Association has made the rebuliding of the Boston Fish Pler a reality.

Benefits derived from this Grant is indeed an integral part of the flshing posture which is basically related to the enactment of the Fisheries Conservation and Management Act of 1976 March 1, 1977, better known as the 200 Mile Limit. Historically the Boston Fish Pler is recognized as one of the foremost fishing ports in the United States. Primarily a fresh fish port, boats and processors supply markets by trucks within a radius of 800 miles and by air throughout the United States daily. It is interesting to note that periodically the greatest amount of airereight out of Boston is fish.

Employment has 1ncreased approximately 100 new employees in 1977-1978 relating to increased landings of 500,000 pounds with a strong potential growth factor as the catch continues to increase. With the recelpt of Phase I funding committees representing the Massachusetts Port Authority, the Boston Fish Pler Tenants Group, and the Architects/Planners are meeting on a bi-monthly basis discussing methods and procedures that will expedite the construction phase. Phase II which relates to water-sewer system, utlitiles, power plant, truck receiving and shipping, and Improving and reconstructing building is now being considered. 
Mr. Robert T. Hall

January 10, 1979

Page Two

Therefore, we respectrully request that the Economic Development Administration continue the Ir support of the Fish Pier Project and approve funding of Phase II to proceed with the rehablitation of the Boston Fish Pler.

W1th kindest personal regards,

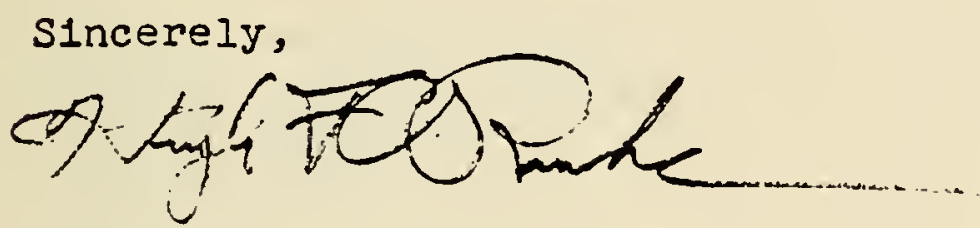

Hugh F. O'Rourke

Executive Secretary

$\mathrm{HFO} / \mathrm{mtm}$

cc: Mr. John Corrigan, Regional Director

Economic Development Adminlstration 
TURNER FISHERIES INCORPORATED

ONE FISH PIER ROAD

EOSTON. MASSACHUSETTS O2210

$(617) 426.6530$

December 26, 1978

iir. Join Corrigan, Director

Ecananic Development adninistration

stlantic Regional Office

亏00 Arch Street

Philacielpiria, Pa. 19106

Dear ir. Corrigan:

The purpose of this letter is to inform you of our whole hearted support for phase 2 of the Boston Fish Pier renovation. Although we are not located on the actual Fish Pier, we iave on-joing vital business relationship with practically all the Fish Pier tenants. These relationships are the cornerstone of our business, and providing these finns with reasonable facilities is of utmost importance.

Horeover, if the rebuilining of 3oston is to proceed along balanced lines, and sinultaneously build employnent. opportunities, tizen tine Boston Fish pier is an extremely important eliement.

We hope and trust that you will fund phase 2 . expeditiously and completely.

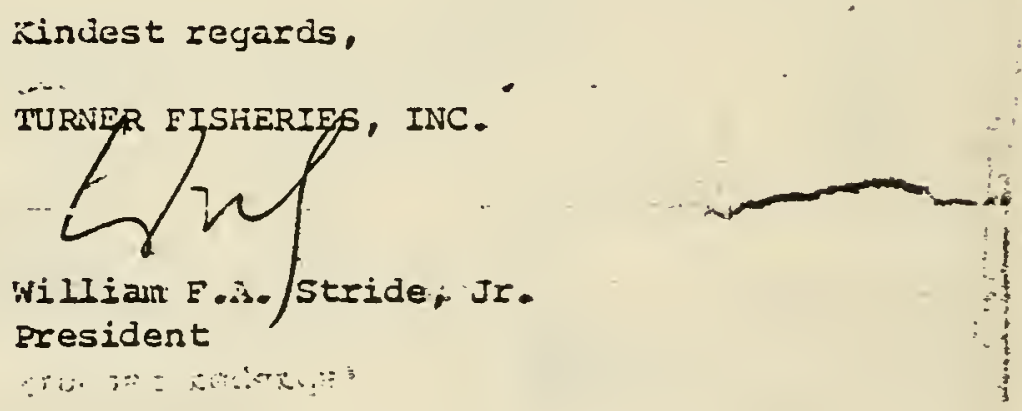

WFAS/j

3CC: :liss Jail L. :ionahan

HIJSPURT .

$\because$ Tu, 99 HAigh 5 t.

Buston, ids. 02110 
OMB Approval Vo. 80-R0190

\section{FEDERAL ASSISTANCE}

1. Type of

XPreapplication

Mark $\square$ Application

appro. $\square$ Notification of intent (Opt.)

priote

box)

4. Legal applicant/reclpient

a. Applicant name : Massachusetts Port Authority

b. Organization Unit:

c. Street/P.O. Box :

d. City

99 High Street

f. State

Boston

Massachusetts

e. County

Suffolk

g. ZIP Code: 02110

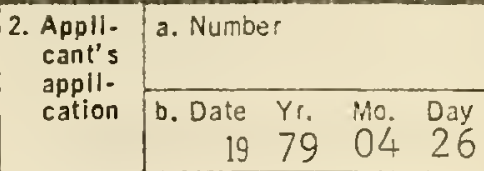

a. SAI Number

applica. 78121676

tion

(SAI)

b. Date

Assigned

1979

$\begin{array}{cl}\text { Mo. } & \text { Day } \\ 1 & 4\end{array}$

Leave Blonk

7. Titie and description of appilcant's project

REHABILITATION OF THE BOSTON FISH PIER

Phase II. The project involves physical renova-

tions of the Boston Fish Pier to stimulate expansion of fishing and related industries, there by stabilizing the existing 1100 jobs and producing an estimated 3000 jobs.

10. Area of project impact (Name of cities, counties, States, etc.)

New England Region

14. CONGRESSIOHAL DISTRICTS OF:

13. PROPOSED FUMDING a. Applicant

a. Federal $\$ 4,500,000.00$

\begin{tabular}{l|l}
\hline b. Applicant $1,125,000.00$ \\
\hline c. State
\end{tabular}

c. State

d. Locai

.00

e. Other .00

16. Project Start Date

9th

unon Y. Mo. Day

b. Project

Estimated number

8090

18. Estimated date to be sub. Yr. Mo. Day

17. Project Duration $*$

5. Federal employer identification No.

\begin{tabular}{|l|l|}
\hline f. Total & $\$ 5,625,000.00$ \\
\hline
\end{tabular}
mitted to Fed. Agency

20. Federal Agency to receive request (Name, City. State, ZIP Code)

97904
26

\section{Program a. Number \\ (From \\ Federal \\ Corolog) \\ $\lfloor 1|1| \cdot|3| 0|0|$ \\ b. Title Grant and Loan \\ Program for Public Works and Development}

8. Type of applicant/recipient

A-State H-Community Action Agency

Binterstate

C-Substate Distr.

1.Higher Educational inst.

D-County

E-City

F-School District

G-Special Purpose

District

$J$-indian Tribe

$K$-Other (Specify)

9. Type of assistance

A-Basic grant D-insurance

B-Suppl. grant E-Other(Specify):

C-Loan

(Enter oppropriate (etter s))

\section{Type of application}

A-New C-Revision

B-Renewai D-Continuation

E-Augmentation

(Enter oppropriote ietter)

15. Type of Change (For I2C or I2E)

A-Increase dollars $F$-Other (Specify)

B-Decrease dollars

C-Increase duration

D-Decrease duration

E-Cancellation

(Enter appropriate letter(s))

19. Existing Federal identiflcation number

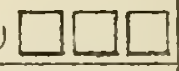

Phase I: 01-01-01749

21. Remarks added (See Sec. IV)

\section{2. \\ The \\ Applicant \\ certifies: \\ 23. \\ Certifying \\ represen- \\ ative \\ a. To the best of my knowledge and be- lief, data in this preapplication/applica- tion are true and correct, the document has been duly authorized by the govern- ing body of the applicant and the appli. cant will comply with the attached assur- ances if the assistance is approved. \\ a. Typed name and titie David $W$. Davis Executive Director}

24. Agency name

26. Drganizational unit

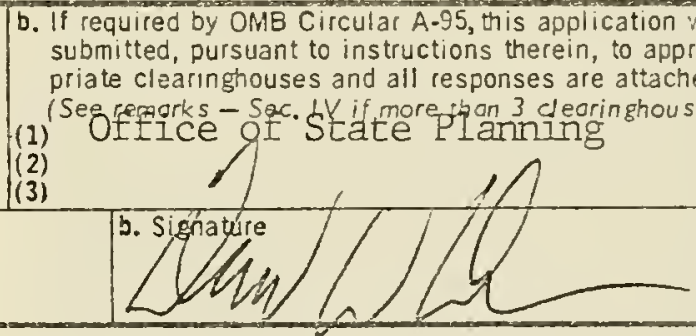
submitted, pursuant to instructions therein, to appropriate clearinghouses and all responses are attached: (Seg remorks - Sac. LY if more than 3 cleoringhouses) Response

27. Administrative office c. Date signed Ys. Mo. Day

19

25.

Application received 19

Yr. Mo. Day

28. Federal application 10

\section{Address}

31. Action taken

a. Awarded

b. Rejected/ Denied

c. Returned

for Amen

d. Deferred

e. Withdrawn

\begin{tabular}{|c|c|c|}
\hline \multicolumn{3}{|c|}{ FUNDING } \\
\hline a. Federal & 5 & .00 \\
\hline b. Applicant & & .00 \\
\hline c. State & & .00 \\
\hline d. Local & & .00 \\
\hline e. Other & & .00 \\
\hline f. Total & 15 & .00 \\
\hline
\end{tabular}

33.

35. Contact for additional information

(Nome and telephone number) Total

33. Action date Year Month
35. Contact for additional information
(Nome ond telephone number)

30. Federal grant iD

38. Federal Agency

Day

34. Starting Date Yr. Mo. Day 19 ate Yr. Mo. Day 19

37. Remarks added (See Sec. IV) $\square$ Yes

${ }^{-}$No

considered. If agency response is due under provisions of Part 1, OMB

Circular A-95, it has been or is being made. b. Federal Azency A-95 ofilicia! (Nome and telephone No.)

5 . $424(10-751$ 
1. Does this assistance request require State, local, regional or other priority rating?...... . Yes X No

2. Does this assistance require State or local advisory, educational or heal th clearance?... $\square$ Yes $\square$ No

3. Does this assistance request require Clearinghouse review? .............

4. Does this assistance request require State, local, regional or other planning approval?... $\square$ Yes $\square$ No

5. Is the proposed project covered by an approved comprehensive plan? ......... $\mathrm{X}$ Yes $\square$ No

6. Will the assistance requested serve a Federal installation?.............. $\square$ Yes $\mathrm{X}$ No

7. Will the assistance requested be on Federal land or installation?........... $\square$ Yes $\square$ No

8. Will the assistance requested have an effect on the environment?............ $\square$ Yes $\square$ No

9. Will the assistance requested cause the displacement of individuals,

families, businesses, or farms?.......................

10. Is there other related assistance for this project previous, pending, or anticipated? .....

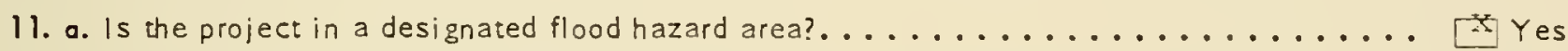

b. Is the project site located in a flood plain? ................... $\mathrm{X}$ Yes

c. Is the project safe from flooding?...................... $\square$ Yes

d. Is flood insurance available? .......................... $\quad[x$ Y es

e. Has flood insurance ever been purchased? .................... $\square$ Y es $X$ No

L. Has the applicant been the subject of any unresolved issues, or negative determinations issued within the past two years, arising from civil rights compliance reviews, complaints, lawsuits or other allegations of discrimination on the basis of race, color, national origin. sex, handicap or age .......... X Yes

PART III - PROJECT BUDGET

\begin{tabular}{|c|c|c|c|c|}
\hline $\begin{array}{l}\text { Federal catalog } \\
\text { number } \\
\text { (a) }\end{array}$ & $\begin{array}{l}\text { Type of assistance } \\
\text { loan, grant, etc. } \\
\text { (b) }\end{array}$ & $\begin{array}{l}\text { First budget period } \\
\qquad \text { (c) }\end{array}$ & $\begin{array}{l}\text { Balance of project } \\
\text { (d) }\end{array}$ & $\begin{array}{l}\text { TOTAL } \\
\text { (e) }\end{array}$ \\
\hline I. 11.300 & $\begin{array}{l}\text { Title I Public } \\
\text { Works Grant }\end{array}$ & & & $\$ 4,500,000$ \\
\hline \multicolumn{5}{|l|}{2.} \\
\hline \multicolumn{5}{|l|}{3.} \\
\hline \multicolumn{5}{|l|}{4.} \\
\hline \multicolumn{5}{|l|}{5.} \\
\hline \multirow{3}{*}{\multicolumn{2}{|c|}{$\begin{array}{l}\text { 6. Total Federal Contribution. ....... } \\
\text { 7. State Contribution ............ } \\
\text { 8. Applicant Contribution ......... }\end{array}$}} & 5 & 5 & $\$ 4,500,000$ \\
\hline & & & & \\
\hline & & & & $1,125,000$ \\
\hline \multicolumn{2}{|c|}{ 3. Other Contributions $\ldots \ldots \ldots \ldots$} & & & \\
\hline \multicolumn{2}{|l|}{10.} & s & $\$$ & $\$_{5}, 625,000$ \\
\hline
\end{tabular}




$$
\text { A-95 Review }
$$

As applies to Part I, Item 22B and PART II Item 3 


\title{
THE COMMONWEALTH OF MASSACHUSETTS
}

\author{
OFFICE OF STATE PLANNING \\ JOHN W. MCCORMACK BUILDING ROOM 2101 \\ ONE ASHBURTON PLACE \\ BOSTON. MASSACHUSETTS 02108
}

(617) 727.5066

ICHAEL S. DUKAKIS GOVERNOR

FRANK T. KEEFE

DIRECTOR

January 4, 1978

Mr. Elliot Friedman

Director of Real Estate Development

and Property Management

Massachusetts Port Authority

99 High Street

Boston, MA 02110

Re: A-95 Review/Rehabilitation of Boston Fish Pier - Phase II

State Application Identifier: 78121676

Dear Mr. Friedman:

Your notice of intent requesting $\$ 4,500,000$ from the Economic Development Administration has been received for review. These funds will provide for the second phase of Massport's rehabilitation of Boston Fish Pier.

As the Governor's designated State Clearinghouse, our review follows the guidelines of OMB Circular A-95. It is designed to provide advisory comments on the consistency of your proposal with State plans, policies, and objectives.

During our review of your proposal, a summary was published in the A-95 Review Monitor, which is distributed to over fifty State agencies. Any interested agency was provided with the opportunity to evaluate your proposal for consistency with its particular policies and objectives. No comments have been received to date.

The Office of State Planning has also reviewed your proposal and as no conflicts. or issues were identified, we concur with your application for federal funds.

Thank you for your cooperation during this review process.

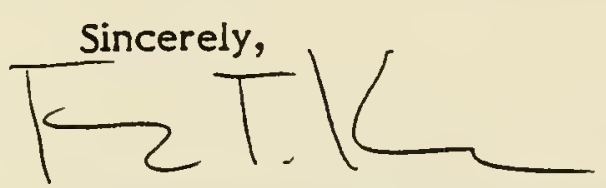

FRANK T. KEEFE

/Ims

Director of State Planning

cC: MAPC 
January 17,1978

Mr. Curt Danforth

Office of State Planning

One Ashburton Place

Boston, MA 02108

Dear Mr. Danforth:

I am writing you this letter to ask for your cooperation on a matter involving Massport and A-95 Review.

Last fall, Massport submitted an application to EDA for federal funds for the rehabilitation of the Boston Fish Pier. In a letter from Frank Keefe to Rose Snyder (September 20, 1977), OSP supported the project and said that the proposal was published in the A-95 Review Monitor (September 9). Also, letter of approval was sent October 13, 1977.

Massport has been awarded $\$ 6.5$ million of federal money: But the federal money is coming in two installments .. \$2 milition for first year and $\$ 4.5$ million for the second year. EDA has notified us that we might have to go through the A-95 process again, since the project has been divided into two phases.

If you concur with our judgment that the A-95 Review procedures have already been complied with, we would appreciate a letter from OSP to Massport, stating that. Such a letter should provide the assurances to EDA that the A-95 requirements have already been fully complied with.

Phase I will consist of Pier, Site Work and Utilities, salt water distribution, plus some core and shell improvements to buildings 1 \& 2 , and some smaller items of. architectural, survey and boring work. Phase II wiII include fresh water distribution, the sanitary/storm system, and the utility. tunnels, utilities, new utility service lines in street and all buildings plus street paving. The core and shall improvements to Power plant Building and apron and truck dock will also be included in Phase II. 
(ii) ( 
Mr. Curt Danforth

Page Two

January 17,1978

In summary, the conditions of the EDA grant in two phases in no way seriously alters Massport's plans set forth in the Application for Federal Assistance for Rehabilitation of the Boston Fish Pier (September 1978). cal1.

If you need further information, do not hesitate to

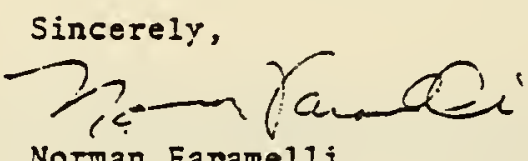

NF/Cr 


\section{THE COMMONWEALTH OF MASSACHUSETTS}

OFFICE OF STATE PLANNING

JOHN W. MCCORMACK BUILDING ROOM 2101

ONE ASHBURTON PLACE

BOSTON. MASSACHUSETTS 02108

$1617) 727.5066$

GOVERNOR

FRANK T. KEEFE

DIRECTOR

January 30,1978

Mr. Norman Faramell1

MASSPORI

99 B1gh Street

BOeEOR, MA 02110

Dear . Farame11:

In response to your letter of Jamuary 17 th concernigg the A-95 review of the Boston F1sh Pler Renovation Program, no additional A-95 review will be required for your second year granc. The materlal proolded for the foficial revlew of thls profect clearly outlined all the rork to be cooducted under the two seperate phases, and as such is an adequace review for the awarding of the $\$ 2$ ullifon for the first year and the $\$ 4.5 \mathrm{mill1}$ (10n for the second year.

The coments subwitted by the MEPA unit in the Erecutive Office of Envlromental Affairs during che review of your project, suggest the need for a MEPA reviev. I suggest you contact Ms. Madellee Rolb at 727-5830 to clarify this polnt and beg1n the necessary steps.

We are glad to hear you were successful in your application for EDA funding. The work when completed w11 greatly enhance che Pfer's utillty to the flohtag fleet as well as preserving an lmportant landrark of the Boeton Wacerfront.

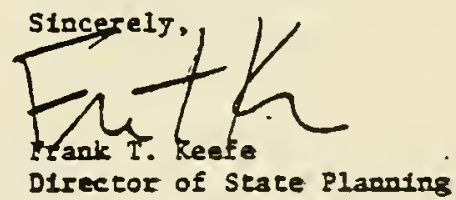

\footnotetext{
/lins

cc: Mdeline Rolb, MEPA

Lorratne Payne, MAPC
} 
() 


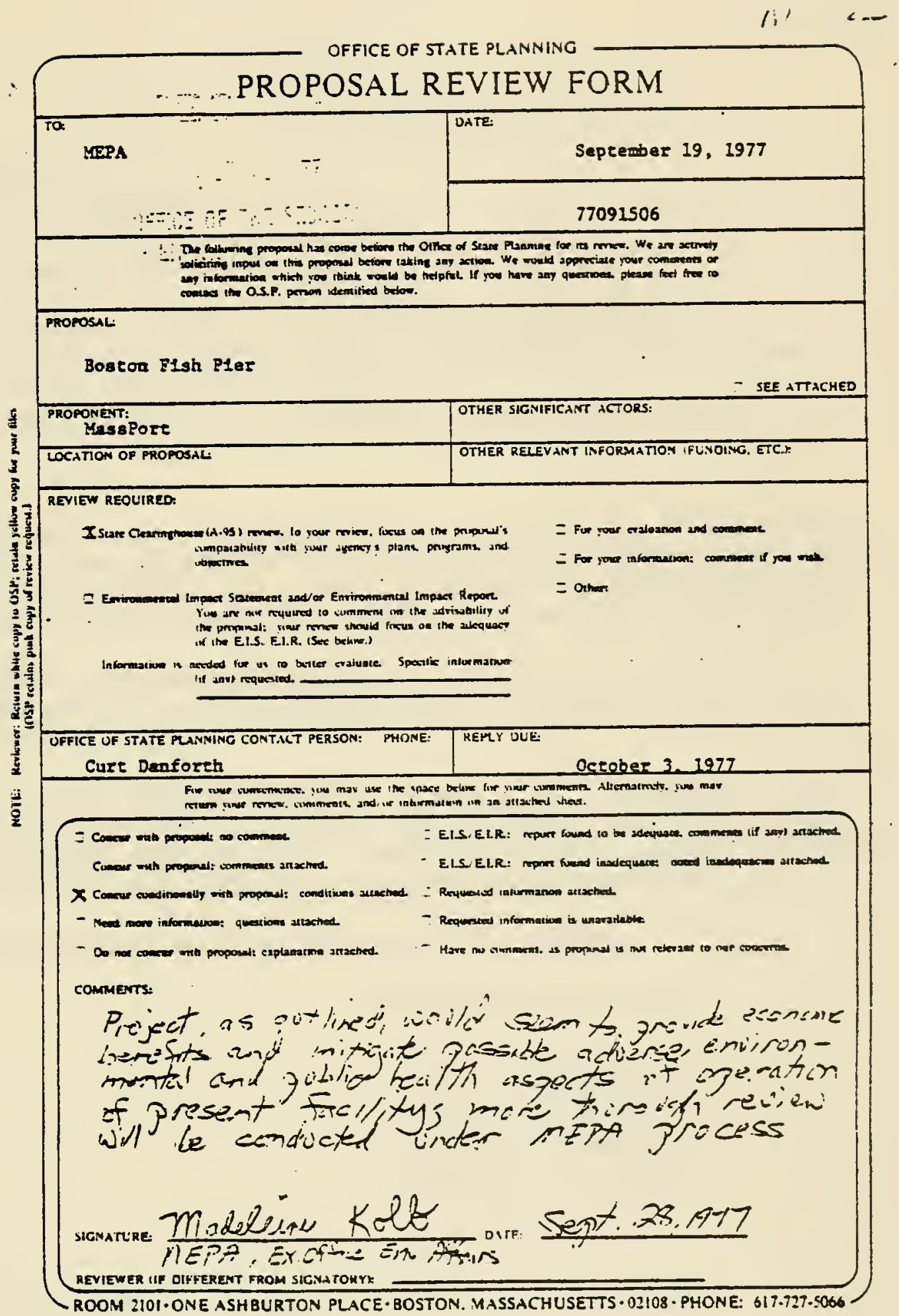


Mr. David W. Davis

Massachusetts Port Authority

99 High Street.

Boston, Massachusetts 02110

$R E: \quad D O C / E D A$ - Grants \& Loans for Public Works \& Development Facilities - Rehabilitation of the Boston Fish Pier - Boston.

(MAPC \#A-78-73; Received January 3I, 1978)

Dear Mr. Davis:

In accordance with the provisions of the 0.S. Office of ning Council, as metropolitan clearinghouse, has reviewed the above referenced application for federal financial assistance.

Based on the information available to us, we find the proposal in general to be consistent with existing plans and policies of the council.

The Council has requested that Ms. Gail P. Rotegard, MAPC representative from Boston, and $M r$. Philip Zeigler, from the Boston Redevelopment Authority - expedite their review comments. Their responses will be forwarded to you upon receipt.

We wish you success in obtaining EDA funding.

very truly yours,

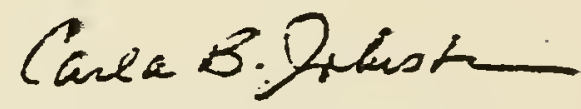

Carla B. Johnston

Executive Director

$\mathrm{CBJ} / \mathrm{md}$

Cc: Mr. Frank T. Reefe

office of State Planning

Ms. Gail P. Rotegard

MAPC rep., Boston

Mr. Philip Zeigler

Boston Redevelopment Authority 


\section{PART II ATTACHMENTS}

Item 3: A-95 Review: Please see the attachment to Part I, item $22 \mathrm{~b}$ for $A-95$ and related responses.

Item 5: Inclusion in comprehensive plans: Rehabilitation of the Boston Fish Pier is considered a priority development project in the Boston Plan, the City of Boston Overall Economic Development Plan, and the Metropolitan Area Planning Council. The Office of State Planning supports the Rehabilitation, emphasizing the need for revitalization of the fishing industry in the Economic Development Plan for Massachusetts. 
Section 10 Related Funding.

10A. CETA Title I

Massport is exploring the possibility of establishing an on the job training program for Fish Pier processing firms under Title VI of the Comprehensive Employment Training Act. Last year Massport began a CETA Title I program, employing six CETA workers at the Fish Pier. When the workers' terms expired this fall, Massport hired four of them. Massport also applied for an additional six CETA Title I workers.

10B. Phase I of Fish Pier Rehabilitation

Phase I of the renovation of the Boston Fish Pier involved pier and site work and exterior rehabilitation of the buildings.

However before the pier can resume its position of prominence in the fishing industry extensive rehabilitation will have to be undertaken. The pier will be able to provide the facilities needed by the modern fish processing plants currently envisioned by these private firms - once both phases of renovation are complete. Phase II will include interior work to the buildings, all utilities, and possibily changing the grade of the pier.

million.

Phase I cost $\$ 2.5$ million, with EDA supplying $\$ 2$ 
PART II.

11. The Boston Fish Pier area is considered a flood hazard area (See Special Flood Hazard Area Map attached) and is located on a Flood Plain.

After consultation with the regional Flood Insurance Office of the U.S. Department of Housing and Urban Development, Massport has determined that Flood Insurance will be necessary for the Fish Pier Rehabilitation, since the project involves not only pier rehabilitation but the rehabilitation of buildings. The Flood Insurance Office requires a grantee to purchase the maximum amount of insurance or an amount of insurance equal to the amount of the grant, whichever is less. Upon acceptance by the EDA of this project Massport will be able and willing to purchase flood insurance.

12. The Massachusetts Port Authority has had three allegations of discrimination in the past two years, two of which have been dismissed. [Caggiano (State and Federal Equal Employment Opportunity Commission (EEOC) vs. MPA, 1977, and Hyacinth (State EEOC) vs. MPA 1978] The third allegation [Devereaux (State EEOC) vs. MPA] is now being investigated. 


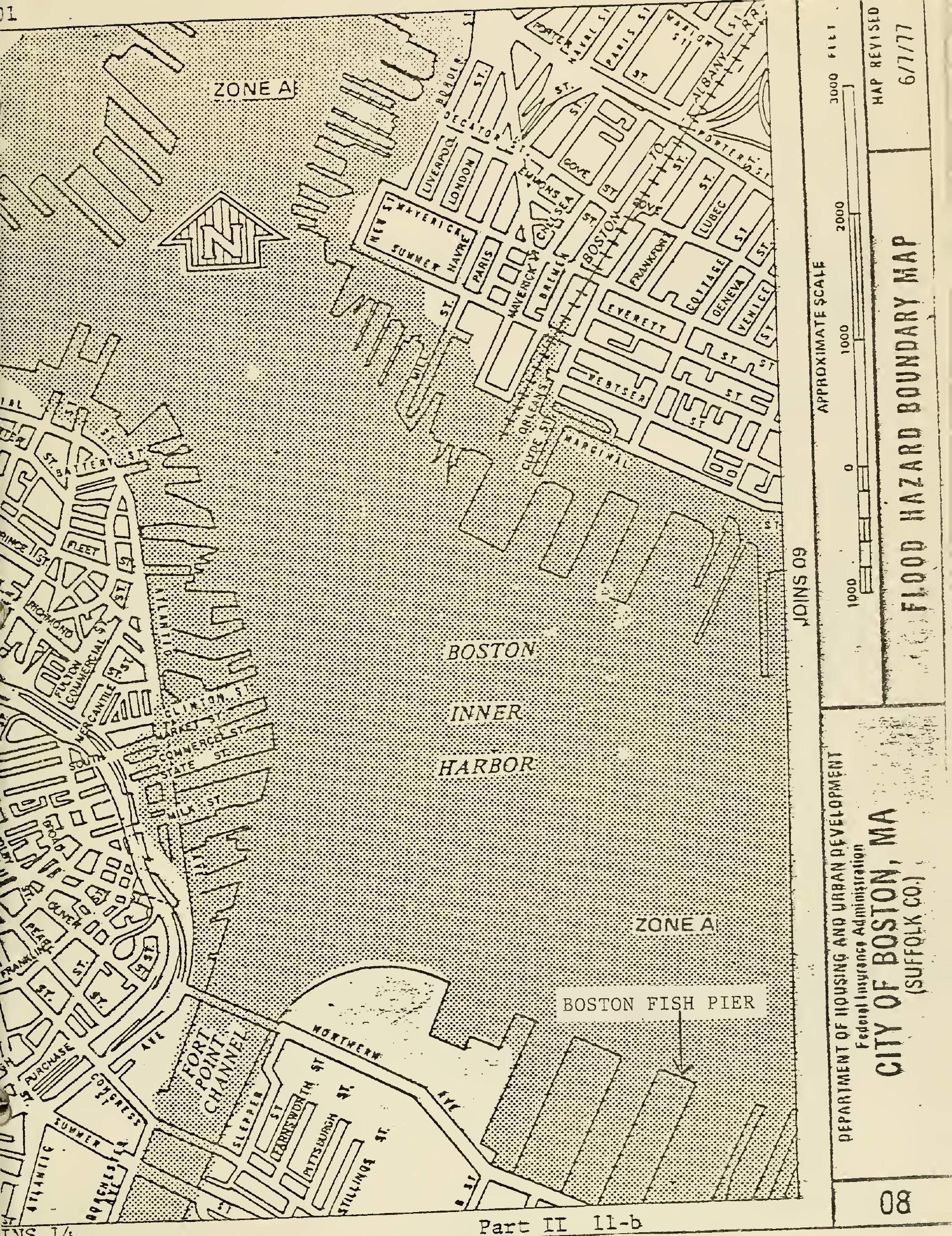




\section{CERTIFICATE OF NON-RELOCATION}

To be Executed by Applicants for Direce Grants or Supplementary Grants Under Title 1 and for Public Torks and Development Facility Loans Under Tirle II, Sec. 201.

Note-- The Public Works and Economic Development Act of 1965 prohibits EDA from making loans or grants which will have the effect of assisting an employer in moving jobs from one area to another. An expansion of an existing business to a new location may be assisted if such an expansion will not cause unemployment in other areas where the business conducts operations, or will not enable contractors or subcontractors to undertake contracts or subcontracts heretofore performed elsewhere, the performance of which would result in an increase of unemployment at the previous location of such work. Execution of the following Certificate is necessary for EDA to determine the eligibility of the subject project in this regard.

Project

Rehabilitation of Boston Fish Pier

(Nature of Project)
Off Northern Avenue in South Boston, Massachusetts

(Location)

I certify that I am

Executive Director

(oflicia! Title)

\section{Massachusetts Port Authority}

(Applican:)

and that the above named Public Works and Development facility project is not undertaken for the purpose of serving an industrial and commercial enterprise which has relocated its operations into the area during the past 24 months or for the purpose of assisting, soliciting or otherwise encouraging the relocation of any industrial or commercial enterprise, and that the applicant is not presently negotiating with an industrial or commercial enterprise which intends to relocate or to curtail its operations in another location with the intention of utilizing the ahove named facility when it is constructed. In the event that after the date of execution of this Cerrifigate and prior to final disbursement, an agreement is reached between the applicant and any/ineustrial or comorercial enterprise to use the Development facility, the applicant will norify EDA of such agregment and sobmit the game or names of the enterprise involved.

April 1979

(Date)

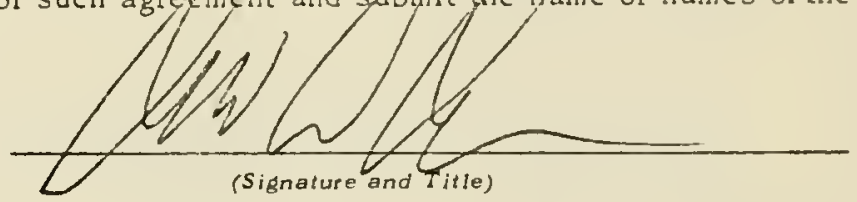

(Signature and Title)

For Massachusetts Port Authority (Applicant)

Note - Section 710(a) of the Public Works and Economic Development Act of 1965 provides that: "Whoever makes any statement knowing it to be false, or whoever willfully overvalues any security, for the purpose of obtaining for himself or for any applicant any financial assistance under Section 101, 201, 202, or 403 or any extension thereof by renewal, deferment or action, or otherwise, or the acceptance, release, or substiturion of security therefor, or for the purpose of influencing in any way the action of the Secretary, or for the purpose of obtaining money, pruperty, or anything of value, under this $\mathrm{Act}$, shall be punished by a fine of not more than $\$ 10,000$ or by imprisonment for not more than five years, or both." 
All programs and benefits under the Public Works and Economic Development Act, including loans, grants, technical assistance, and training will be administered with strict adherence to the policy of denying assistance to businesses which are seeking to relocate or which relocated in the recent past.

Section 2, the Declaration of Purpose of the Public Works and Economic Development Act states that under the provisions of this Act new employment opportunities should be created by developing and expanding nex and existing facilities and resources rather than by merely transferring jobs from one area of the United States to another.

Section 202 (b)(1) of the Public Works and Economic Development Act Provides that EDA financial assistance shall not be extended to assist (1) industrial or commercial establishments relocating from one area to another, (2) expansions which would result in unemployment in any area where the business entity involved conducts its operations or (3) contractors or subcontractors whose purpose it is to seek the transfer of contract rootk presently performed at another location.

It is the policy of EDA to construe the general prohibition against relocation in Section 2 as applicable to all sections of the Act. The specific language in Section 202 (b)(1) provides further guidance to EDA in carrying out the policy of Section 2 and is used by EDA as a guide in rendering assistance under other sections of the Act. Applicants for development facility loans and grants or for supplementary grants must therefore assure EDA, prior to seceiving financial assistance, that they are not constructing the facilities for the purpose of serving a relocaten business firm, that they are not then negotiating with a telocating firm, and that they have no intention of using the project to induce industries to relocate into theit areas. Similar assurances rill be required from industrial and commercial users of development facilities if such facilities are constructed primarily or substantially for their use.

It is not always easy to identify what constitutes the relocation of a business enterprise and its associated jobs. In some instances the movement of machinery and equipment may in practical effect be the movement of the business enterprise. In other instances the business enterpcise is more appropriately identified and characterized by a trade name, customer lists, and other intangible assets. EDA will carefully examine all transfers of ownership, liquidations and curtailment of operations which bear any telationship to the proposed establishment of a new enterprise. In all cases, the controlling consideration will be whether the effect is the relocation of jobs from one area to another.

Ordinarily the phrase "from one area to another" as used in connection with relocations means from one labor area to another. Nevertheless, EDA will consider in evaluating a project any adverse effects which may indirectly result from a celocation ever though the new location may be wholly within the boundaries of the same labor area or the same redevelopment area or district.

The limitation on assisting in relocations is applied both to prospective moves and those made in the recent pasts For instance, EDA will not assist a relocated industry in a new location even though the withdrawal or curtailment of employment at the previous place of business was substantially completed at the time of the request for assistance from EDA. Any such earlier relocarion, a part of which was carried out within 24 months prior to an application for EDA assistance, shall be subject to the rebuttable presumption that the EDA assistance tequested is causally related to the relocation.

EDA can assist in true expansions through the establishment of new branches, affiliates, or subsidiaries, provided that such expansion will be carried out and operated without increasing unemployment at other places of business of the enterprise. To give effect to this limitation, EDA will inquire into the undertakings and operations of affiliated enterprises or enterprises under common control with the particular business which is to be benefited by the proposed project.

In considering whecher a proposed expansion will result in an increase in unemployment at other facilities of a business enterprise, EDA will consider, among other things, traditional as well as current operating levels of employment, changes in demand for worker skills at the existing facilities, changes in capital investment at th existing facilities, and any relationship the proposed expansion may have upon the future prospects for operation of such existing facilities. 


\begin{tabular}{|l|}
\hline Name of Project \\
Boston Fish Pier Rehabilitation \\
\hline City and State - \\
Boston, Massachusetts \\
\hline Project No. iv/A \\
\hline
\end{tabular}

ASSURANCES OF COMPLIANCE WITH THE DEPARTMENT OF COMERCE AND THE ECONOMIC DEVELOPMENT ADMINISTRATION REGULATIONS UNDER TITLE VI OF THE CIVIL RIGHTS ACT OF 1964 AND PUBLIC LAW 92-65

This form applies to: A. all Recipients receiving Federal financial assistance from the Economic Development Administration including: 1 . applicants;

2. recipients of Federal financial assistance received from another recipient; 3. subgrantees; 4. leasees of or operators for a recipient; 5 . successors, assignees or transferees, but not ultimate beneficiaries; and $B$. Other Parties to include any governmental, public or private agency, institution, organization or other entity, or any individual who has a direct or substantial participation in the program or project receiving Federal financial assistance from EDA, such as contractors, subcontractors, providers of employment, or users of the facilities or services.

Massachusetts Port Authority

Name of Recipient or Other Party

(hereinafter called the "Recipient or Other Party") assures that as a Recipient or Other Party receiving Federal financial assistance from the Economic Development Administration, it will comply with Title VI of the Civil Rights Act of 1964, as amended ( 42 USC $2000 d$ ), the requirements imposed by or pursuant to Regulations, issued for the Department of Commerce and designated as 15 CFR Subtitle A Part 8, and any amendments thereto.

The Recipient or Other Party further agrees to comply with the provisions of Section 112 of Public Law 92-65 (42 USC 3123), the requirements imposed by or pursuant to the Regulations of the Economic Development Administration promulgated in $13 \mathrm{CFR}$ Part 311 and any amendments thereto. In addition, Recipient agrees to secure the compliance or to cooperate actively with EDA to secure the compliance by others with the acts and the regulations.

Such requirements hold that no person in the United States shall on the ground of race, color, national origin, or sex be excluded from participation in, be denied the benefits of or be otherwise subjected to discrimination under any program or activity for which Federal financial assistance has been extended.

In accord with these assurances and without limiting the above, the Recipient or Other Party agrees that these assurances shall be binding upon them, their grantees, assignees, transferees, leasees, and successors in interest. These assurances shall also be binding through every modification or amendment to this project. 
The Recipient or Other Party acknowledges that it has received and read the Department and EDA regulations, and that it is aware that if there appears to be a fallure or threatened fallure to comply with this part, and if the noncompliance or threatened noncompliance cannot be corrected by informal means, compliance with this part may be effected by the auspension or termination of or refusal to grant or to continue Federal financial assistance or by any other means authorized by law.

Total number of present employees

This assurance is made and accepted this , 1979

, for The Massachusetts Port Authority day of Febnary

\section{Recipient or Other Party}

By

David W. Davis

(Type Name)

Executive Director

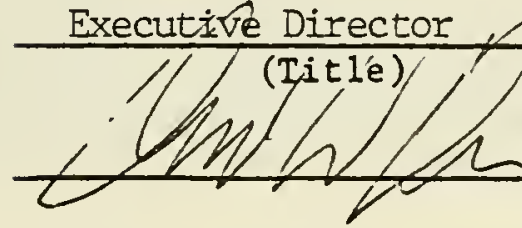

99 High Street

(Address)

$: 0$

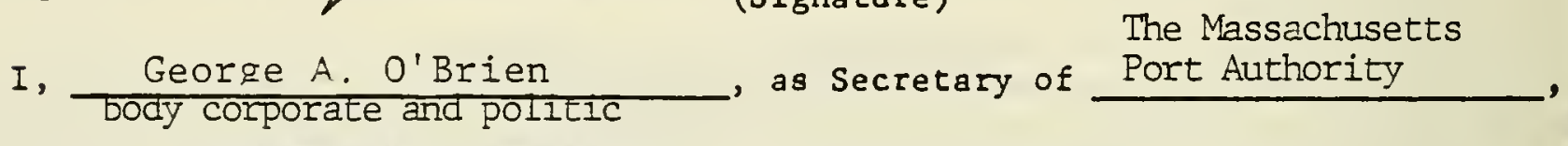

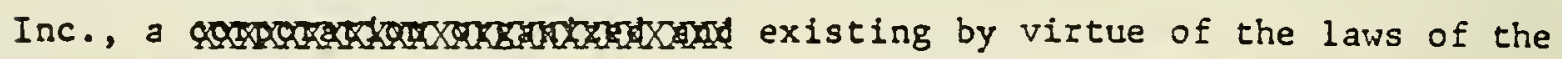

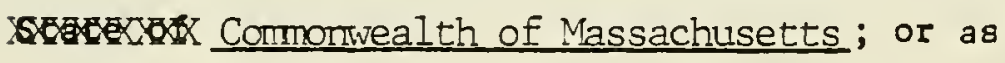

Authorized State Official

of the State of ; or as

Authorized official

of the county or municipality of in the State of

do hereby certify that the foregoing officer who executed this assurance has full authority to bind the Recipient or Other Party. In witness whereof I set my hand and affix the corporate, state, or municipal seal this day of April 1979 


\section{ASSURANCE OF JOB OPPORTUNITIES FOR THE UNEMPLOYED}

(See Explanatory Statement on back of form)

To be Executed by Business Development Loan Applicants and by Employers who are Substantial Beneficiaries of Public Works Facilities under Title I and II of the Public Works and Economic Development Act of I965, as amended.

PROJECT DESCRIPTION

Rehabilitation of the Boston Fish Pier. Phase II the project

involves physical renovation of the Pier, its buildings and utilities

to provide facilities for and stimulate expansion of fishing and related industries.

PROJECT LOCATION

The Boston Fish Pier, Pier "1"6 is lecated off Northern Avenue in

South Boston, a section of the City of Boston.

\section{STATEMENT}

The undersigned recognizing the purpose of the Public Works and Economic Development Act of 1965 as described on the reverse side of this form, represents to the Economic Development Administration the intention to give preferential consideration for employment, wherever possible, to the long-term unemployed and underemployed residing in the project area, in connection with the above identified project and the undertaking assisted thereby, and that the dara submitted herein is correct.

EMPLOYER'S IDENTIFICATION NO. $\quad x-1$

FOR OFFICIAL USE ONLY

DATA CONTROL NO. $X-10$

PROJECT NO.

-

FIPS CODES

\begin{tabular}{ll}
\hline CITY & A-2S \\
\hline & $A 029$
\end{tabular}

STATE

COUNTY

S. 1. C. NO.

TYPE BENEFICIARY $x-13$

A-31

A-34

A. 78

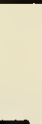

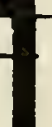

NAME OF APPLICANT OR BENEFICIARY A-38

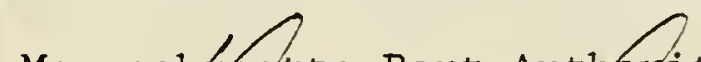

Massachrisetts port Autbrority

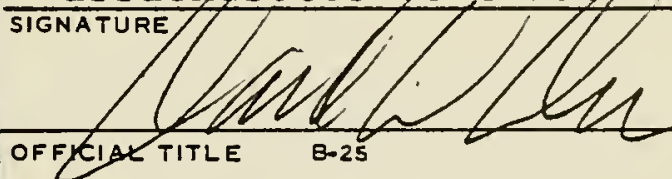

Executive Director

STREET

B-5S

99 High Street

CITY C-25

ZIP $\quad C-60$

Boston

5TATE C.45

Massachusetts

COUNTY

c.6S

Suffolk
B-79

$17|9|$

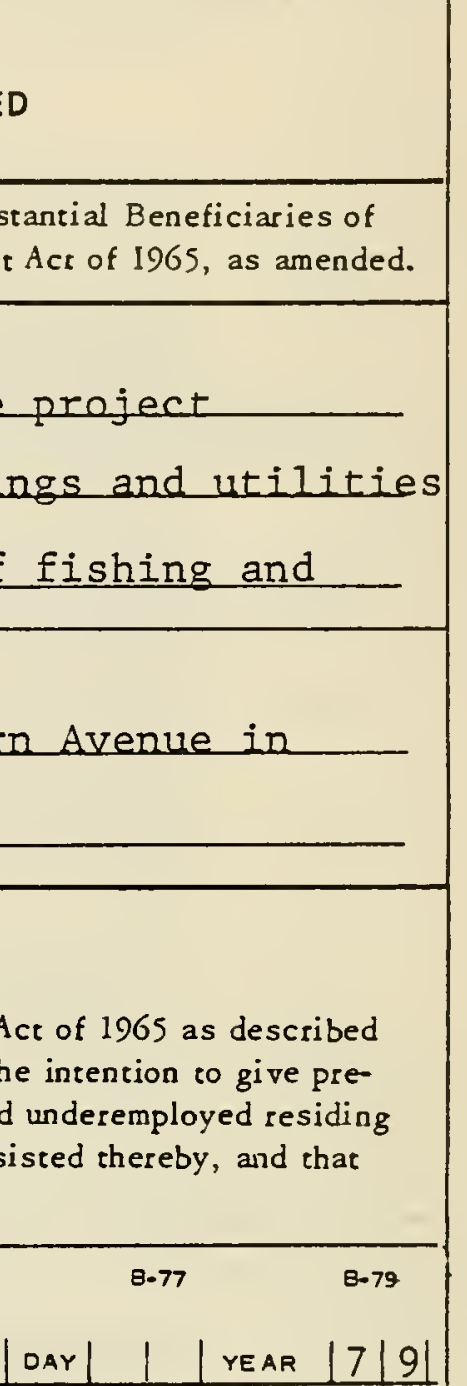




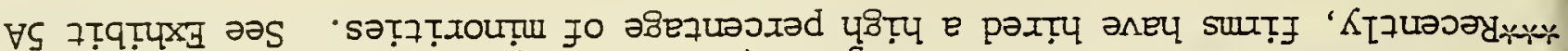

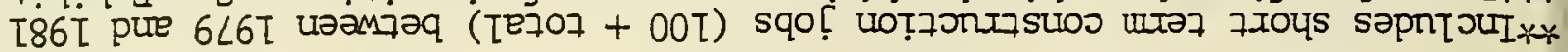

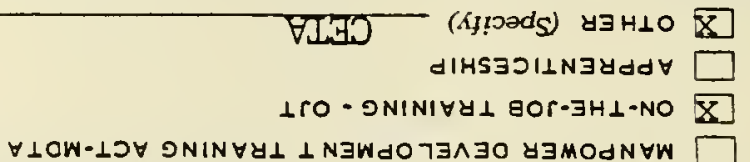

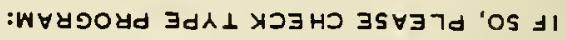

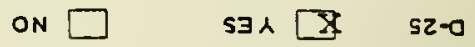

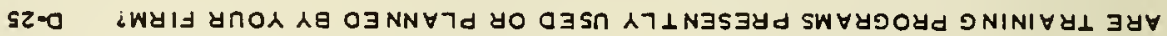

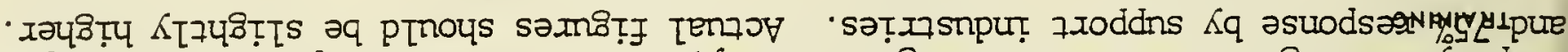

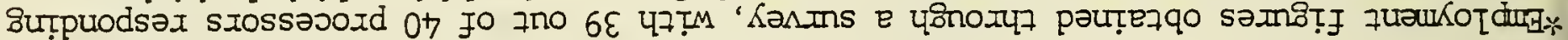

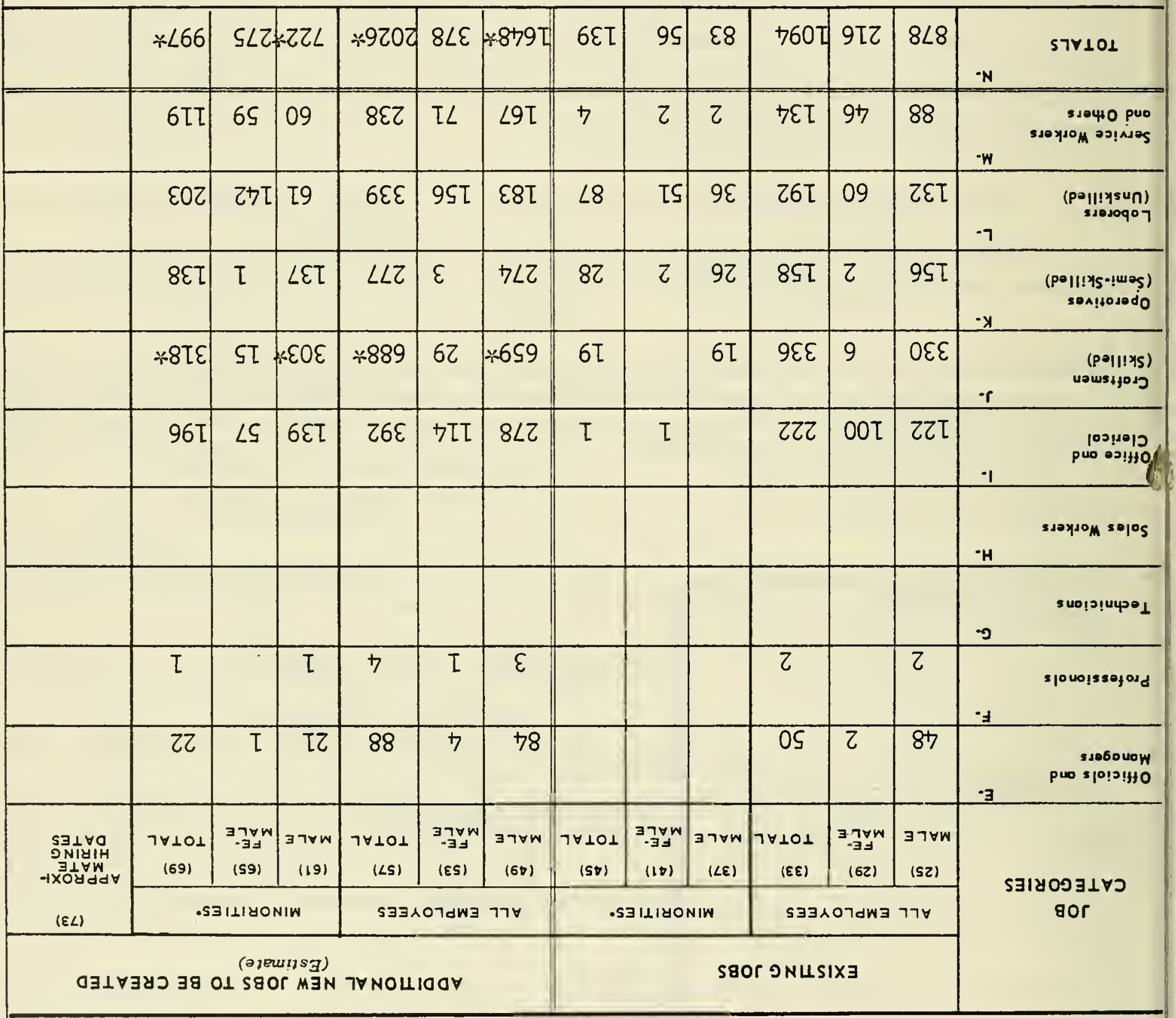

. Inaly 'ouths 'uetpul ubotsamb '

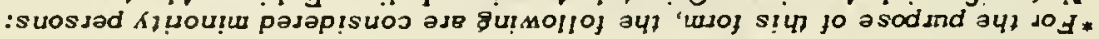


All programs and benefits under the Public Works and Economic Development Act of 1965, as amended, including loans, grants, technical as sistance, and training will be administered wich strict adherence to the policy of providing jobs wherever possible for the unemployed and underemployed residing in the designated areas el egible for EDA assistance.

Sec. 2, the Declararion of Purpose of the Public Works and Economic Development Acr, states that the Federal Government, in cooperation with the States, should help areas and regions of substantial and persistent unemployment and underemployment to take effective steps in planning and financing their public works and economic development.

Title I, Sec. 101(a)(1)(A) of the Act provides that EDA can assist when, "The project for which financial assistance is sought will directly or indirectly (i) tend to improve the opportunities, in the area where such project is or will be located, for the successful establishment or expansion of industrial or commercial plants or facilities, (ii) otherwise assist in the creation of additional longterm employment opportunities for such area, or (iii) primarily benefit the long-term unemployed and members of low-income families or otherwise substantially further the objectives of the Economic Opportunity Act of 1964 ".

It is the policy of EDA to give the highest consideration to those projects which will provide jobs for the unemployed and underemployed residing in the project area.

Employers benefiting fron EDA-assisted projects must assure EDA that they will wherever possible give preferential consideration for employment to the unemployed and underemployed residing in the designated area in which the project is located.

It may not.always be possible to fill existing job vacancies from the ranks of the unemployed. In order to operate their businesses successfully, employers may seek qualified and skilled workers through their own established methods. However, consideration must be given to the unemployed labor force which qualifies the distressed area for EDA designation and thus enables such area to apply for Federal Loans and/or grants under this Act.

There exist established local, State, and Federal agencies and programs to assist employers in hiring and training qualified employees. The State Employment Services, State, and local vocational schools, and Federally assisted skill centers are specifically charged with collecting and recording pertinent data and available job skills and will assist in evaluating and preparing the unemployed to fill job vacancies.

Employers who are beneficiaries of EDA-assisted projects, when preparing their present and future employment plans and programs, should discuss such plans and programs with the appropriate agencies cited above before offering employment to workers residing outside the designated area.

In order to ensure that maximum feasible employment opportunities are made available to the unemployed residing in the project area, EDA requires applicants for public facility loans and/or grants to submit executed Form ED-612 and to obtain and submit to the government, together with the application, properly executed Forms ED-612 from all employers who are cited as beneficiaries of EDA-assisted projects.

EDA also requires each Business Development Loan applicant to submit to the Government, togerher with the application for financial assistance, a properly executed Form ED-612.-

Under the regulations of the Department of Commerce implementing Title VI of the Civil Rights Act (1964) and Section 112 of EDA's Act, recipients of EDA business loans as sistance (including their lessees, users, and operators), and substantial beneficiaries of public works assistance are required to take affirmative action to ensure that applicants are employed, and employees are treated during employment without regard to their race, color, national origin, or sex. Substantial beneficiaries of public works'assistance are defined as those industrial and commercial enterprises or public errtities which (1) are cited in the application and (a) provide all or part of the justification of the project or

$\because \cdot(b)$ will, as a direct result of EDA's assistance; create or save ten (10) or more jobs, or (2) al though not cited in the application, in the opinion of the Assistant Secretary, provide all or part of the justification of the project.

Although all public works grant and loan,recipients and substantial beneficiaries are covered by Title VI, those substantial beneficiaries who as a result of the project will construct a new facility at which they intend to employ 50 or more employees, or intend to expand the work force at the present facility by adding 50 or more employees are required to submit an affirmative action program. Further, each applicant for business loan assistance that employs or intends to employ 50 or more persons at the proposed EDA-assisted facility shall submit, as part of the application for such assistance, a written affirmative action program.

A properly executed Form ED-612 will be considered an essential part of the Affirmative Action Program. 
suorj

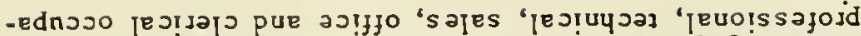
'ferjageuew 'jetsijo joj guruten [euroi ui pagegua suos - d do 'suorjednjo asinjas pue jajoqel 'anijejado-swej8

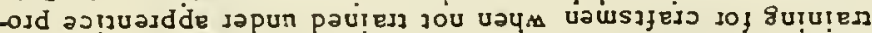
[eunof u! pagegua suosiad sapnjoul - saau!olt qo!-ayt-uo

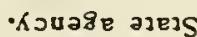
jo [ejapa $\mathrm{e}$ 4

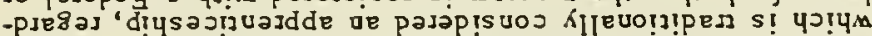

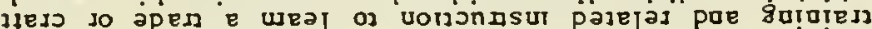
भৃIOM 8 I

- siariom pajpuix pue 'sassamiea pue siajien 'sjajiod

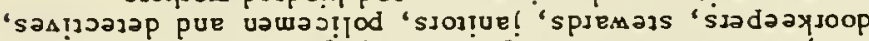

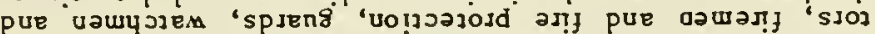
-ejado jojenaja "sjayjom uiejunof pue jasunos "(

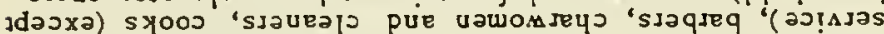
jeuosiad pue jeuorssajoid "suorjnalasur jaypo pue sjezid -soy) sjuepuajue isapn[ou -suotjednjoo astajas antzวaj

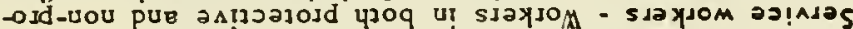

- sjayjom paspuit pue "suoit?

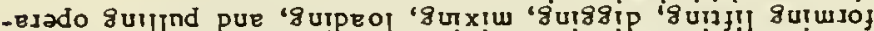
-jad sjajoqel 'sıaddoy

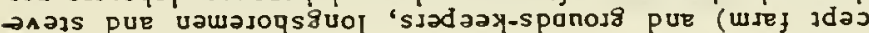
-xa) sjouzpjeg 'sjaseajg pue sjaysem jes 'sjajoqet agejeg

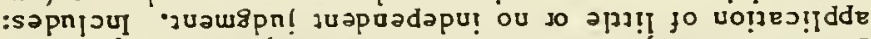

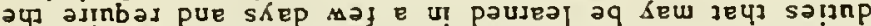

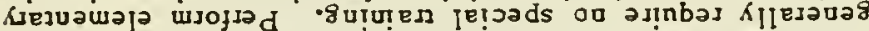

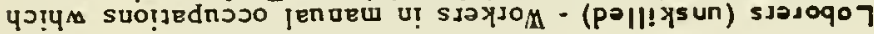

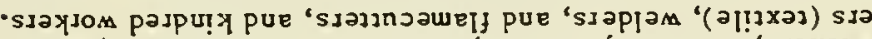

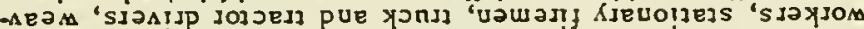
ssasojd jrudefoloyd "(asoevajulew pue vorjonnsuos jdas

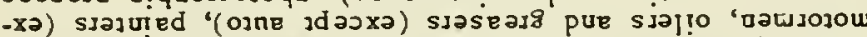

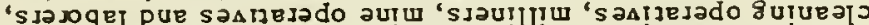

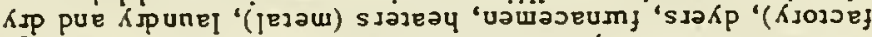

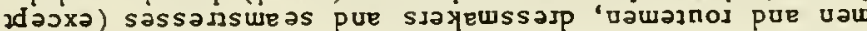

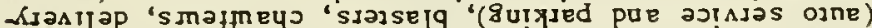

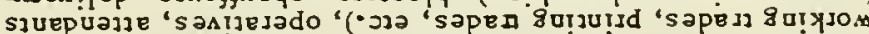

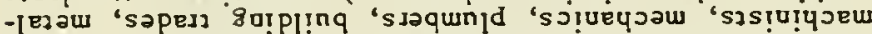
" -uajdde :sapnjou .

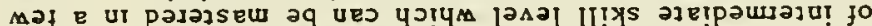

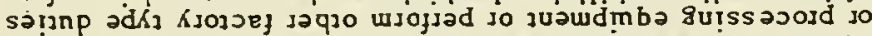

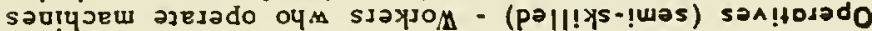

- sjayjom pajpuir pue 's assajo -itel pure sjoflej 'sjazurgua krenorjess "sjayew japow pue ujajzed "sjsiugijoalojd amjord vorjow (ןejaw) sianas qoi

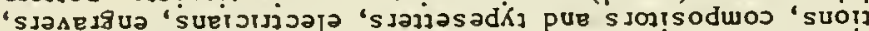

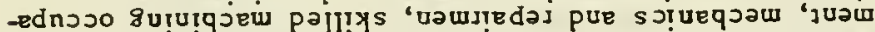

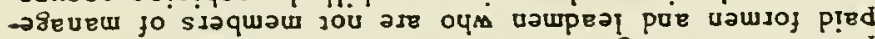

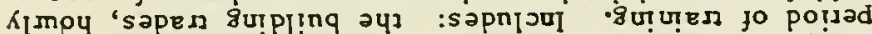

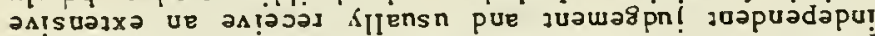

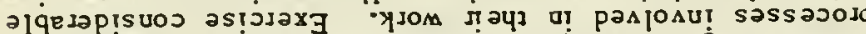

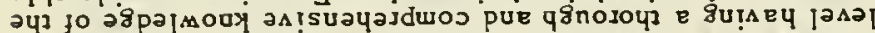

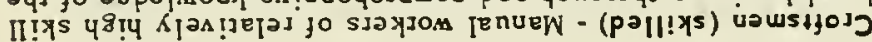

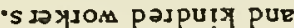
'sjojejado auoudajaj poe ydejlajaz 'sarjejajoas pue sisid

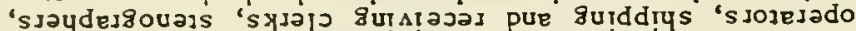

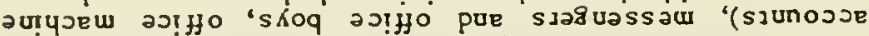

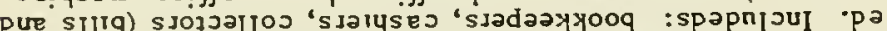

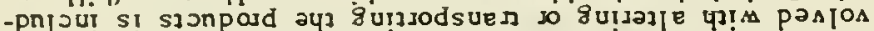

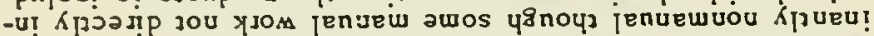

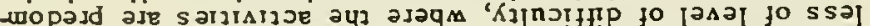

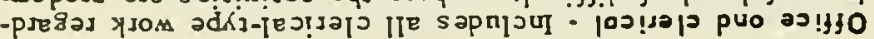

- sjayjom pajpuiy pue is pue uaws jes 'sjojejusuouap 'uawsajes puoq pae yools 'sjayojq pue sıuage ajejsa jeaj 's jayorq pue sjuage ajueins

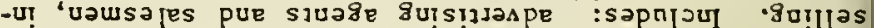

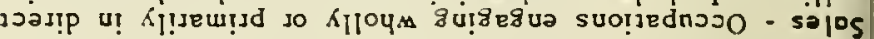

- sjayjom pajpuiy pue

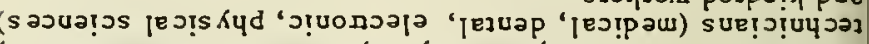

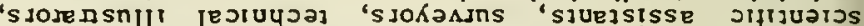

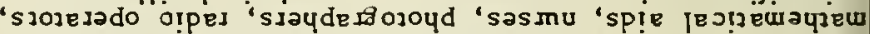

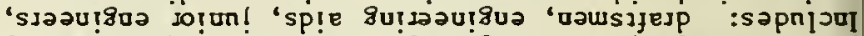

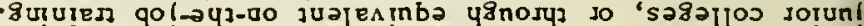

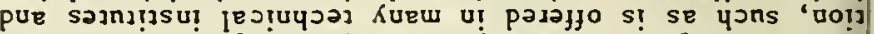
-eगnpa jooy

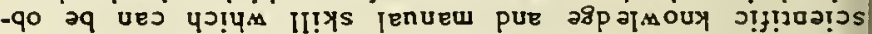

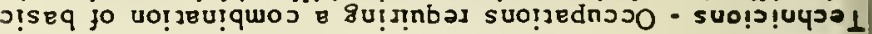

- siayjom paspuix pue sjayjeaz sisizuatos jerzos 'suetriskyd 'stsijuaros [ejiskyd "siayjom suorze]

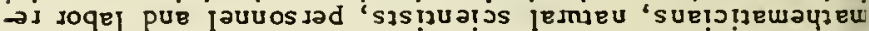

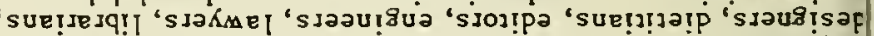

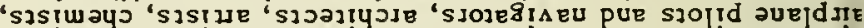

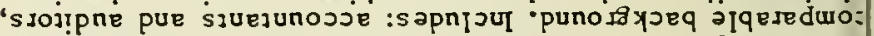
e apisosd or se junowe pue pury yons fo əoualjadxa jo uor: -enpers a8ว

-sjayjom paspuit pae 'siaknq pue sjuage $8 \mathrm{u}$ -s ey and ' 2 awagevew fo sıaquaw ase oỵ uawajof patjefes 'sjuap dajuijadns pue sjageuew juamjedap 'sjageueur suej6

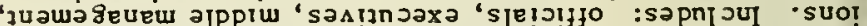
-EIado s, wI!f e jo saseyd jeijads jo sjuauniedap jenpia!l

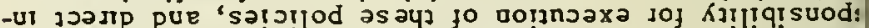

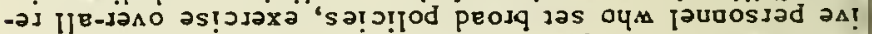
-eizsiuimpe guijinbaj suoijednjo - ssabouow puo sjo!j!jtC

sa!1062405 qor to uo!td!usg

- unof sty at s readdi

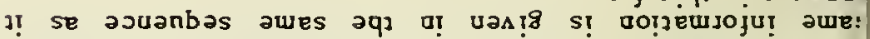

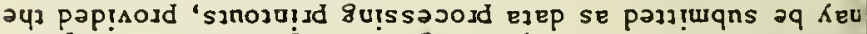

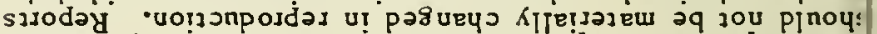

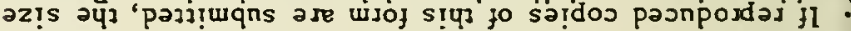

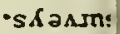

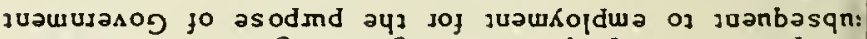

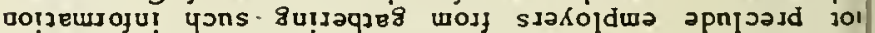

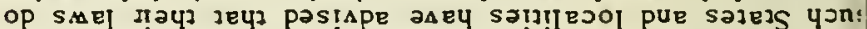

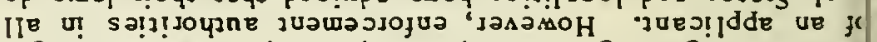

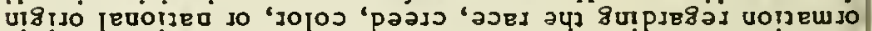

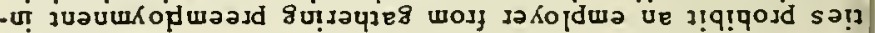

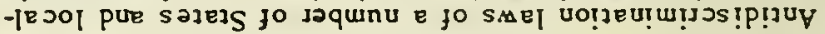

-8niguojaq se kitunuwos aup ut papjegajsi jo " 8 uol

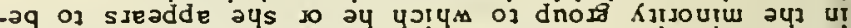

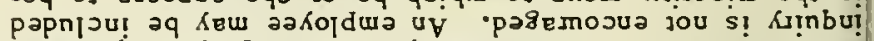
jכalp Kq a

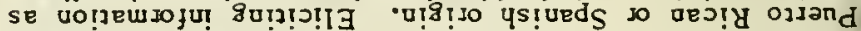

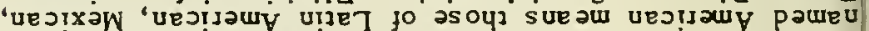

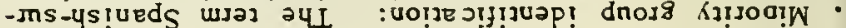


1. A. Need for Rehabilitation

1A. Attachments

1. Letter of Interest

1B. Description of Project

1B. Attachments

1. Work Description

2. Resolve \#I - 1976 Act and Resolves of the General Court of Massachusetts.

3. "The Fishing Industry in Massachusetts report prepared for the Massachusetts Port Authority, November 1977 of Pier Rehabilitation.

2. Attachments

1. Boston Fish Pier Employment Survey.

2. Letter from L. Nealon, President of Seafood Workers Union.

3. Massachusetts Port Authority Non-discrimination Equal opportunity and affirmative Action Policy and Program .

3. Statements of Overall Economic Development Programs.

Boston Plan

Boston OveralI Economic Program

Metropolitan Area Planning Council's Overall

Economic Development Plan.

Economic Development Plan for Massachusetts. 


\section{EXHIBIT IV-1a}

Boston and the New England region are in need of jobs. Growth of the fishing industry can help fulfill this need while allowing the inner city and the region to take advantage of the opportunities for expansion afforded by the 200-mile limit. Fishermen, boat owners, processors, packagers, transportation firms, retailers, restaurants, and consumers would all profit from fishing industry revitalization.

Processing firms are anxious to begin modernizing their operations in a rehabilitated Boston Fish Pier. Private investment in the area stimulated by this development will amount to $\$ 60$ miliion of investment. Numerous firms have contacted the Port Authority expressing interest in leasing space at the fish pier. However, because of the imminent plans for rehabilitation Massport has not leased space to them. Any improvements made would only be destroyed when rehabilitation work begins. Also, new tenants occupying now vacant bays would only make the provision of "swing space" during rehabilitation more difficult.

Boston is the historical center for the fishing industry and, more importantly, is located at the region's transportation center for both truck and air shipments. There is a firm foundation for substantial industrial growth at the pier. But the facility must be improved and modernized to realize its potential. Private industry's willingness to invest, however, depends on Massport's 
ability to finish construction on the Fish Pier, which in turn depends on the EDA's financing of Grant II for the project.

Forty fishing firms currently operate at the pier and $n$ Northern Avenue. (See Attachment IV-2). The decline of the past vears is just beginning to reverse as these firms formulate plans for the renovation of their stores.

New containerization options for air freight will enable fish processing companies to greatly expand their markets. Previously it cost 55-60 cents per pound to ship fish to the West Coast. Now, however, a processor can use LD 3 containers to send 3,000 pounds of fish at one time at a reduced cost of 20 cents per pound. Using LT2 containers reduces the cost further to 14 or 15 cents per pound when shipping 8,000 to 10,000 pounds of fish. Some firms are now considering shipments to Europe by air as catches there decline due to the $200 \mathrm{mile}$ limit, and the West coast market is opening up to Boston based firms.

The expansion of firms on the Boston Fish Pier will result in additional employment opportunities in a city with a high unemployment rate and a scarcity of blue-collar jobs. New entrants tend to be minorities, and a CETA program is in existence at the Fish Pier and expanding to bring in more unemploved. Growth in fishing and fish processing will also result in related growth in sectors which service this industry and in the marketing and distribution sectors of 
the economy.

In addition, the city and region will benefit from the rejuvenation of the fishing fleet and pier in ways that cannot be quantified. 
Outlined below are recent requests for space on the Fish Pier that the Massachusetts Port Authority has received. Names of the dealers are omitted.

Type of firm

Lobster dealer

Lobster dealer

Shellfish dealer
Soace Requested

$14,000 \mathrm{sq}$. ft.

undetermined

undetermined
Type of Use

Will use this outlet in Boston as a distribution center.

Interested in retail arrangement on the Fish Pier.

Interested in opening a distribution center in Boston. 


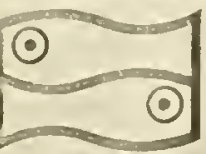

Mr. Elliot Friedman

Massachusetts Port Authority

99 High Street

14 th Floor

Boston, MA 02110

Re: Boston Fish Pier

Dear Mr. Friedman:

I am submitting a lease request for approximately 900 square feet on the Boston Fish Pier. This space would be utilized for the purpose of buying, selling, storage and distribution of fresh fish products. This facility will not be used for fish processing and the floor space will require an area suitable for a storage cooler, staging area and an office. Our Company, Golden Eye Seafoods, is a packer/processor of fresh $\mathrm{fish}$ and scallops in New Bedford.

If any further information is required in order to proceed with a lease request, please contact me at this telephone number: 1-617-995-3321.

Sincerely,

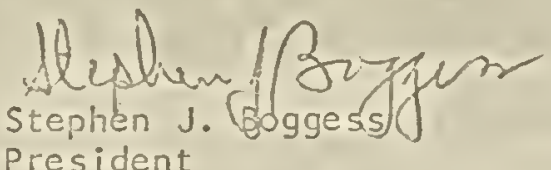

$\mathrm{SJB} / \mathrm{aml}$ 


\section{EXHIBIT IV-16}

The Boston Fish Pier has served as the center of the region's fishing industry since its construction in 1912, providing emplovment for over 1,000 workers and a source of fresh and frozen fish for New England and the nation.

The pier is 1200 feet long and 310 feet wide. Four buildings remain on the pier: Buildings 1 and 2 house the majority of the fish processors in the area. The New England Fish Exchange is located in Building 3 at the end of the pier. Building 6 , at the Northern Avenue end of the pier, is unused except for the boilers which provide steam for heating and hot water to all buildings of the facility. The Fish Pier was acquired by Massport from the Commonwealth of Massachusetts Acts of 1956 as one of the "port properties". The pier was operated privately until 1972. In that year the operators of the pier, the Boston Fish Market Corporation, sold the lease to the Massachusetts Port Authority.

Until 1977 landings at the Boston Fish Pier had declined steadily since peak years in the late 1930's when annual landings were over 300 million pounds. By 1961, according to the National Marine Fisheries Service of the U.S. Department of Commerce landings at the pier had fallen to 117 million pounds and the port of Boston ranked tenth in the list of "Landings at Certain U.S. Ports".

The year 1977 marked a turning point for the New 
England fishing industry. In 1978 landings had increased to 27 million pounds, a 20\% increase from 1977 landing totals of 22 million.

Furthermore, even during the so called "lean years" for New England fisherman Boston fish processors were handling a great deal of fish. In 1978, trucked-in fish exceeded fish landed by boat in Boston: 46 million pounds of fish were brought in over the road. This makes the total fish processed at the pier 73 million pounds.

The New England fishing industry is at a turning point. Industry and government experts expect that during the next five to seven years the fishing industry's decline will be reversed due to five factors:

1. The enactment of a 200-mile fishing zone:

The Fishery Conservation and Management Act of 1976 established a limited fishing zone of 200 miles of the coasts of the United States. Fishing within the zone is regulated by the U.S. Government. Limited species may be fished by foreign boats only if U.S. fishermen's catch falls below quota and total catch may not exceed quota. Thus the bill protects the U.S. fishing industry from excessive competition on the part of foreign subsidized boats and protects the fish stocks from long range population depletion. During the six month period after implementation of the limit, Boston fishermen reported an increase in their catch of $25 \%$ to $30 \%$ over the same period last vear, as 

reported by the National Marine Fisheries Service.

2. Boston Fish Pier's location near fish and labor supplv

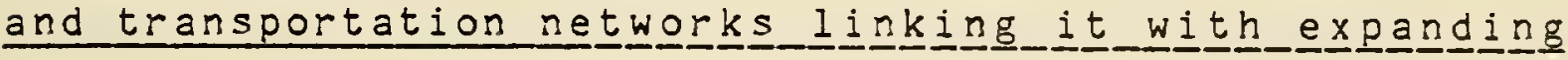
markets: Situated near the productive Georges Bank, which is expected to yield increasing fish catches during the coming vears, the Boston Fish Pier is the ideal location for fishing industry redevelopment. Pier processors will be able to draw on Boston's large blue collar labor force as their processing plants expand. From Boston's prime location in the center of regional truck routes and only minutes from Logan airport, the firms can take advantage of the expanding markets for fish. The potential for increasing shipments to the Midwest, the West Coast, and abroad is great given the new types of containerization available which allow processors to reduce the cost of shipping fish. In 1977, fresh fish exports provided the sixth greatest tonnage value for all air cargo exports at Boston's Logan Airport. One company on the Fish Pier estimates that their firm's air shipments of fish will increase 40-60\% during the next two to three years.

3. Private and public interests in fleet modernization:

For many years the government has endeavored to provide programs to aid the fishing industry, establishing such programs as the 1960 Fleet Improvement Act which provides loans for fleet construction. In spite of these efforts, the industry continued to decline the 200-Mile Limit seems to have turned this trend around. According to Marine 
Fisheries Service economist, John Rittgers, more than 30 new vessels were added to the fleet in 1977. Three fishing vessels have been added to the Boston Fleet this year.

4. Private interest in investing in fish processing

expansion: Private firms have expressed interest in expansion and development at the fish pier. These firms havee already invested $\$ 1.9$ million in capital improvements that they expect will increase their gross revenues by more than $\$ 23$ milion annually by the third year. Future renovation of the Fish Pier is expected to have a significant impact on the area. Private revenues leveraged by the facility could potentially total 60 million.

The Boston Fish Pier is the logical location for development of the added facilities necessary for revitalization and expansion of the Massachusetts fishing industry. Rehabilitation will be significantly less costly than new construction and will entail only temporary, rather than permanent, relocation as the bavs are prepared for each firm. More importantly, expansion of the fishing industry at the Boston Fish Pier provides development of a regional and national industry in an inner city urgently in need of jobs. If the fishing industry in Boston is to take advantage of the 200-mile limit and renewed interest in fishing, rehabilitation of the pier is essential.

In 1976 the 200-mile work group - an ad hoc group assembled by the Lt. Governor to study the problems of the fishing industry and its prospects under the 200-mile limit 
administered a questionnaire to Massachusetts fishermen, fish processors, fishing cooperatives and fish marketing organizations. Of the 500 questionnaires distributed, 67 were returned from 18 Massachusetts ports and harbors, Boston included.

In this questionnaire Boston fishermen and processors stated that the absence of mechanical equipment to unload a catch was a serious problem. The respondents also felt that a cold storage and freezing facility would be very important if Boston is to serve as a major landing port. In ranking facility needs, Boston questionnaire respondents gave highest priority to new processing plants. Feelings about the Fish Pier are summed up in the words of one respondent, "The present Fish Pier, with reasonable maintenance and sprucing up, is more than adequate for expansion from the view of boat owners. However, the pier processing facilities are a disgrace and must be improved and expanded to cope with additional landings in the future."

Last year, the Port Authority applied for and received an EDA Title I grant. These monies will be used to carry out phase I of the rehabilitation of the fish pier and will cover some pier and site work, improvements to the exterior of buildings $1,2,3$ and the Power Plant, selected interior improvements, and some smaller items of architectural survey and boring work. The monies from the grant being sought now will be used to complete sections of the work begun under phase I. 
The two phases of this project are intricately interrelated. It would have been much more economical and efficient to plan for and carry out construction in one phase. This has proven to be financially infeasible for Massport and the EDA. However, it is important that the two phases be as contemporaneous as possible.

This rehabilitation cannot be done without help from the Economic Development Administration. The pier has suffered from several decades of neglect and will need extensive work to be modernized.

In light of the arguments presented above, Massport urges the EDA to approve this application for Title I monies to rehabilitate the Boston-Fish Pier as expeditiously as possible. 


\section{WORK DESCRIPTION AND ESTIMATED COST}

The Fish Pier is 1200 feet long and 310 feet wide. Four buildings remain on the pier. Buildings 1 and 2 house the majority of the fish processors and wholesalers in the area. The combined total floor area of these buildings is 212,000 square feet. Building $3(20,000$ sq.ft. $)$ at the end of the pier houses the New England Fish Exchange. The Power Plant is a six story building at the Northern Avenue end of the pier.

A number of physical improvements, have been implemented in Phase I of this work, aimed at revitalizing the Boston Fish Pier and the Boston fishing industry. What follows is a summary of proposed improvements for the various project components that will complete the revitalization begun in Phase $I$ and a brief description of conditions and needs. Additionally, there is a summary of construction costs reflecting realistic estimates of the dollars needed to proceed. 
I. Site Work and Utilities:

A . Regrading and repairing of Pier Surfaces

Remove existing cobblestone and asphalt surface and regrade interior street to approximately six (6) inches below existing elevation.

New base coat and chip asphalt paving on interior street. Grade and pave archway areas from street to new apron surface. Include catch basins. New concrete paving on apron area and raise apron elevation approximately one foot above the existing elevation. Reinforced, acid and waterproof, 6" concrete, 6" gravel base. (New concrete surface to be extended to all first floor and loading dock areas of Buildings 1 and 2. See specifications for Buildings 1 and 2).

\section{B. New Utilities}

Major utility repairs and replacement, including fresh water, treated salt water, heat, electricity and sewage, are essential for the proper functioning of the Fish Pier. The system renovations proposed are briefly as follows :

\section{Utility Tunnels}

Most of the utilities servicing the Fish Pier are located in a system of excavated spaces under the first floors of Buildings 1, 2, 3 and the Power Plant. Since these tunnels have no concrete walls or floors, corrosion 
and water seepage are serious problems. No drainage is provided except percolation through the earth floor. Pipes and conduits are corroded and leaks exist in the pipes. Electric wires hang loose from the ceiling of the tunnel and repairs to the electrical system are dangerous because of water in the tunnels. Major improvements must be made to these tunnels.

\section{Salt Water Distribution and Treatment}

A supply of salt water is necessary for the cleansing of the pier and its apron. But problems occur with the distribution system during low tide. If salt water is not available, FDA sanitary regulations require that the pier be shut down. Installation of a new pump and a chlorination treatment system are proposed. Also a return line and separators for treatment of washdown salt water.

\section{Eresh Water Distribtution}

Fresh water is distributed to the buildings from the city water main on Northern Avenue, through the utility tunnels. The valves of the water lines and the piping within the buildings need to be replaced as well as sections of the primary line. 


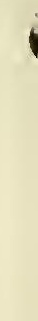


Sewage System: Sanitary/Storm

All plumbing fixtures and floor drains at the pier are connected to the municipal sewage system. No adequate separation of storm sewer from sanitary lines exists. The sanitary lines, as a result, require frequent flushing due to the large amount of fish scales and trimmings which are admitted into the system through the floor drains. Obstructions have been noted in the sewage lines and in connections into the main municipal sewer line. In addition, fill underneath many of the sewer pipes has washed away, causing many pipes to crack and pollute the harbor. These sanitary and sewage lines must be separated, requiring considerable reconstruction and replacement of lateral and main sewage and sanitary lines.

\section{Gas Distribtuion}

Gas will be available to the Boston Fish Pier area but the existing lines are not adequate to supply the proposed new gas fired heating system. A new main distribution line will be installed in the pier street with necessary laterals to all buildings.

\section{New Heating System}

\section{Heating}

All buildings on the pier are now heated through a central boiler system, consisting of two high pressure steam 
boilers. They were designed to generate high pressure steam to operate turbo-electric power generators and steam-operated refrigeration equipment (both of which are out of operation). These boilers are presently being operated at greatly reduced pressure generating steam for hot water and heating only. This reduced pressure operation diminshes the efficiency of the boilers and results in significantly higher operating costs. In addition, the existing system supplying the various tenants is not metered individually. Tenants are billed on the cube footage of the area they occupy.

This system has outlived its functional life. The boilers and piping must be replaced with a new system that would include individual metering to tenants to regulate fuel consumption and to charge tenants equitably.

Proposed are individual, gas fired heating units for each dealer and packaged roof-top gas fired units for the third floor office space, Buildings 1 and 2. Separate gas fired units are proposed for Building 3 .

II. Core and Shell Construction Improvements to Buildings $1,2,3$ and Power Plant

Construction improvements include all work required to rehabilitate and upgrade the interior and exterior of the basic buildings not included in Phase I: structural elements, repointing of brick at first floor and replacement of doors and lighting, sub floors, major interior walls, 
stairs, rough utility distribution and any attendant demolition. The result would be a finished building shell ready for finishing and occupancy by tenants.

Core and shell construction does not include any finishes, construction or mechanical equipment particular to a specific tenant's needs. Building 3 includes all work not done in Phase I.

Truck dock canopies attached to Buildings 1 and 2 are also included in the core and shell construction as necessary improvements to the exterior of the buildings. For sanitary reasons the FDA has recommended that those areas adjacent to the building where the loading and unloading of fresh fish takes place be provided with canopies.

The primary use intended for Buildings 1 and 2 is continued and expanded fish dealer and processing on floors 1 and 2. Floor 3 will provide new rental space for office use. The two archways in each building will be utilized to provide major access to the 3rd floor tenant spaces. New ground floor lobbies will include elevator and stair access to the third floor.

Construction improvements outlined below include all exterior work required to rehabilitate and upgrade the exterior of the building not included in Phase I. 


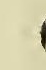


A. BUILDINGS 1 AND 2

\section{Exterior}

1. Replace windows and doors. All of Floor 1 and parts of Floors 2 and 3 not included in Phase $I$.

2. Repair door lintels and window lintels and sills.

3. Patch, repair, and paint stucco, all sides, 2nd and $3 r d$ floor areas.

4. Clean and repoint brick and stone work with epoxy grouting where possible and reconstruct where necessary.

5. Resurface and flash roof areas not included in Phase I.

6. Remove exterior concrete stair from two archways.

7. Remove all wood structures from two archways, 1st and 2nd floors.

8. New exterior lighting at all overhead doors, entrances to archway area, and general lighting of outside areas.

\section{Interior}

1. Floor 1:

a. General demolition.

- remove all existing concrete stairs.

- remove all existing partitions between party walls.

- clean existing utility tunnel and remove all existing pipes, conduit, etc. 
- miscellaneous demolition and cleaning.

- remove tile block party walls as needed.

b. New concrete floor, including loading docks, 6 inch gravel and 6 inch reinforced, acid and waterproof concrete. Extend floor drain.

c. Dock levelers, $6 \mathrm{ft}$. length $\times 5.5 \mathrm{ft}$. width with 12 inch differential capacity. (Installation by tenant, as needed).

d. New steel pan concrete filled stairs, 52 total.

e. Patch and paint all masonry ceilings.

f. Clean and repoint any interior brick work.

g. New utilities.

h. Rough-in utilities (plumbing, electrical and heating).

i. New masonry party walls as needed.

j. Install cross or K-bracing where required.

2. Floor 2:

a. General demolition.

- remove all existing concrete stairs (65).

- remove all tile block party walls as needed.

- remove all existing partitions between party walls.

- remove all existing toilet rooms and fixtures. 
- miscellaneous demolition and cleaning.

b. Level and resurface all concrete floors.

c. Fill old stair openings in floor (34)

d. Patch and repair masonry ceilings and party walls that remain.

e. New masonry party walls as needed.

f. Install cross or K-bracing where required.

g. Rough-in utilities (plumbing, electrical and heating).

3. Floor 3:

a. General demolition

- remove masonry party walls as needed.

- remove all partitions between party walls.

- remove all existing toilet rooms and fixtures.

remove vent areas above 2nd floor toilet rooms.

- miscellaneous demolition and cleaning.

b. Level and resurface all concrete floors.

c. Fill all stair openings in floor (66).

d. Install egress stair at ends of each building and at the middle of each Building section to third floor to ground floor - (10) 3 floors.

e. Install elevator and stair core at each archway (4), include $3 r d$ and ist floor service with lobby area at ground level in arch. 
f. Rough-in utilties (plumbing, electrical and heating) .

g. Install sprinkler system.

B. Building 3:

Exterior floors 1 and 2:

1. Replace all windows and doors, replace or repair mullions and glass at north and south entrances under arch.

2. Clean and repoint all brick.

3. Patch and repair stucco.

4. Repair and replace copper on parapet, and clean pediment stone work.

5. Repair entrance stairs and sidewalks.

\section{Interior}

1. Clear out existing partitions.

2. Remove existing toilet room fixtures and strip walls.

3. Repair water damage from roof leaks.

4. Repair and paint walls in atrium, corridor and stair areas.

5. two new fire stair and enclose each stair with fire rated wall and door.

6. New toilet rooms.

7. Install new elevator. 


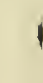


C. Power Plant Building:

Interior:

1. General demolition:

a. remove boilers and demolish smoke stack and coal hoppers.

b. remove interior walls and partitions except concrete wall between boiler room and rest of building .

D. Truck Dock Canopies

These consist of an eight foot projection from the building facade over the truck docks and along the full length of the street side of Buildings 1 and 2 excluding archway areas. A cantilevered light weight metal frame with a transluscent covering is proposed. 

III. INTERIOR RECONSTRUCTION OF FISH PROCESSING

AND FISH INDUSTRY RELATED AREAS:

BUILDINGS 1,2 AND 3

Interior reconstruction of fish processing and fish industry areas includes necessary improvements and renovations to create efficient and functional fish processing facilities and related office and service areas. Reconstruction would specifically include alteration or rebuilding of non-load-bearing partitions, doors, freezer walls and insulation, surface finishes, toilet rooms, mechanical rooms and service.

It would not include special equipment and machinery such as refrigeration units, fish processing equipment, gurry tanks.

Relocation

Construction will be phased to allow for continuing operation of the fish dealers during the construction period. Given that many of the existing bays are vacant, rehabilitation can be phased to reduce relocation expenses. Every effort will be made not to relocate a tenant to a temporary location before they are moved to their permanent rehabilitated location. There may, however, be circumstances where this is unavoidable because of construction cost and staging problems. 
Relocation costs vary greatly according to size of dealer and special equipment (refrigeration, freezing, processing) used. Every effort will be made to avoid relocating dealers with large amounts of freezing and processing equipment. These will be given relocation priorities to avoid unnecessary moves and minimize relocation costs.

A. Fish Dealer Areas, Floors 1 and 2, Buildings 1 and 2 Schematic Design Drawings for fish dealer areas were prepared during Phase $I$ for Buildings 1 and 2 and are the basis for the following outline specifications. Drawings are enclosed.

\section{TENANT FINISHES, FISH DEALERS}

Reconstruction will include alteration or rebuilding of non-bearing partitions, doors, freezer walls and insulation, surface finishes, toilet rooms, locker rooms, mechanical rooms and service. It would not include special equipment and machinery such as refrigeration units and fish processing equipment.

\section{Floor 1}

1. Install cooler/freezer walls, insulate walls and ceiling, install ice bin and insulate.

2. Install two sliding doors.

3. Epoxy paint on all masonry finishes.

4. Plastic tile wall covering in all processing areas. 

5. Install office, including walls with glass panels and doors.

6. Toilet room with ceramic tile wainscot and floors and fixtures.

7. Furred pipe space for utilities.

8. Electrical service.

9. Heating and ventilating.

\section{Floor 2}

1. Office area with suspended acoustic tile ceiling, vinyl asbestos tile flooring and base, interior doors and partitions.

2. Locker area with suspended acoustic tile ceiling, vinyl asbestos tile flooring and base, interior partitions and doors.

3. Mens' and womens' toilet rooms including plumbing fixtures.

4. Paint all walls.

5. Electrical service.

6. Heating, ventilating and air conditioning.

B. Office Space Floor 3, Buildings 1 and 2 Office Tenant finishes will include the following:

1. Drywall finish and paint on all exposed surfaces.

2. Toilet rooms' walls will be finished with ceramic tile and plaster.

3. Doors, including door hardware.

4. Partitions within premises within office space, doors included in partition walls. 

5. Suspended acoustic ceiling.

6. Floor finishes.

7. Lighting.

8. Electrical and telephone service.

C. Building 3, Office Space Alternative

Proposed future use of Building 3 is commercial office space on floors 2 and 3 and alternative commercial or office uses on floor 1.

Office use is proposed for these floors and a square foot cost taken from the outline specifications for Office Tenant Finishes for Floor 3, Buildings 1 and 2 , above, and based on the actual areas of floors 2 and 3 was used to determine the total cost shown in the Construction Cost Summary.

CONCLUSION

The projects outlined here will vastly improve operations at the Fish Pier. Present facilities are detriorated, dangerous and unsanitary. Upgrading the Fish Pier will encourage fish processors and dealers to expand and will attract new business and employment to the Pier. All work described above has been coordinated with the work already in progress under EDA Grant 非1-01-01749. 


\section{COST SUMMARY}

\section{A. Buikeraj \& fender purpas}

A . Regrading and Repaving of Pier

Surface (Street and Apron)

1. Remove existing cobblestone and asphalt surface and regrade.............. 75, 300

2. New base coat and asphalt paving on street.................... 93,000

3. New concrete paving on apron, raise elevation one foot above existing......3 308,900

B. New Utilities

1. Utilities tunnels.............. 349,500

2. Salt water distribution and treatment, fresh water distribution and sewage gas distribtuion and sanitary systems......309,500

C. Heating

1. Individual gas-fired units, Buildings

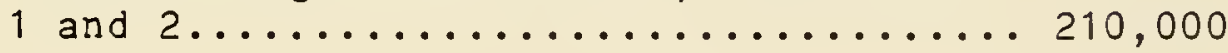

2. Packaged roof-top units, Floor 3, Buildings 1 and 2..............4 420,000

3. Gas-fired units, Building $3 \ldots \ldots \ldots \ldots 8,000$

D. Core and Shell Construction Improvements

1. Buildings 1 and $2 \ldots \ldots \ldots \ldots \ldots \ldots \ldots \ldots, 640,800$

Exterior................ 500,000

Interior............... 1, 140,800

2. Building $3 \ldots \ldots \ldots \ldots \ldots$

Exterior............... 72,900

Interior.............. 194,400 

3. Power Plant Building........

71,000

Interior, general demolition

4. Truck Dock Canopy..........

E. INTERIOR FINISHES OF BUILDINGS $1,2,2$ AND 3

1. Fish Dealer Areas, Floors 1 and 2, Buildings 1 and $2 \ldots \ldots \ldots \ldots \ldots 1,525,100$

2. Office Space, Floor 3, Buildings

1 and 2. ................... 1,058,200

3. Building 3, office Space

Alternative.

128,000 

COST SUMMARY - EDA 101P: PHASE II

I. Site Work and Utilities $1,854,200$

II. Core \& Shell Construction Improvements

$2,259,300$

III. Interior Finishes, Buildings $1,2, \& 3$

$2,711,300$

Sub-Total Construction Costs

$6,824,800$ 



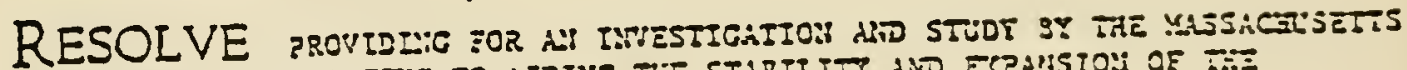

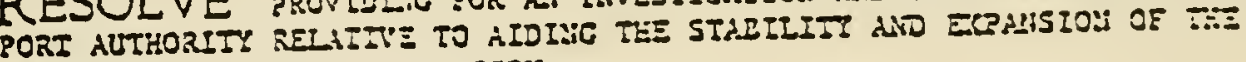
MASSACUUSEDS SERECCD !:DUSZRY.

RESOLVED, That ste Kassacinsetes ?ort iutbortsy is hereby aushortiod and directed to raie 22 1rvestizaeton and sesdy of the subject aneser of

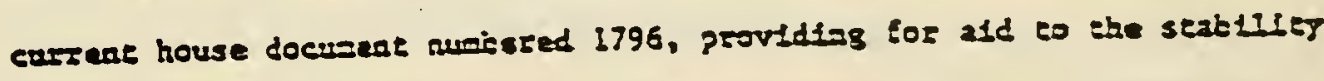
and expasston of the lassachusetes seafood ladusery. Sald duchorts:

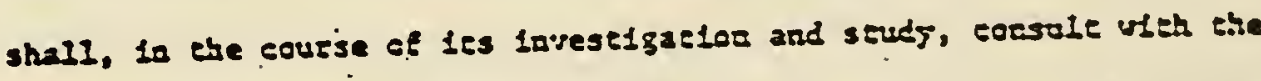

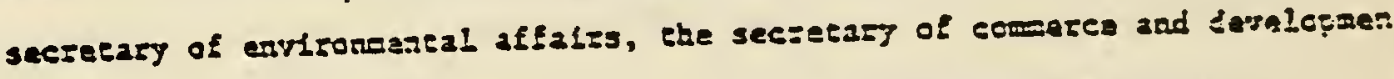
che secrecary of cransportactor and sueh ocher sectecartats 29 =at be recessary.

Sald Auchorley shall coasider but toc be liaised to the collowing:

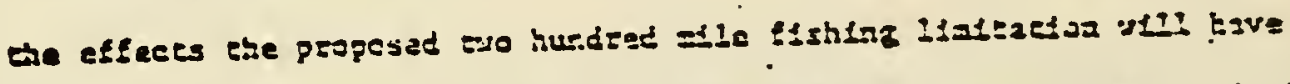

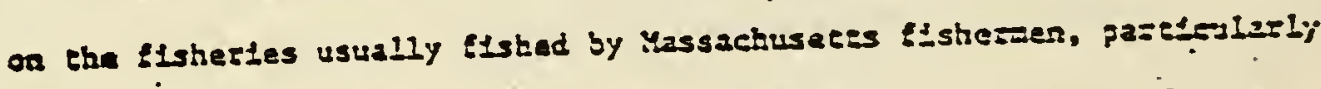

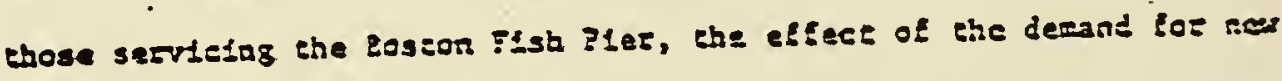

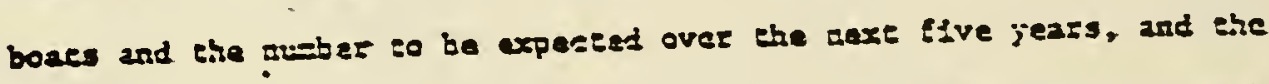
erzinteg of a sufflefeal aueber of persoes to work as fisherean, dects huads, and vartous other oceupations. Satd Authortey shall also constect

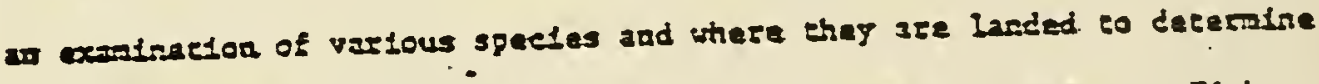
the effeces that such speetes: would have if landed at the Boston Ilsh Plar or varlous other Massachusetes peres. Sald Auchorist shall 2 iso

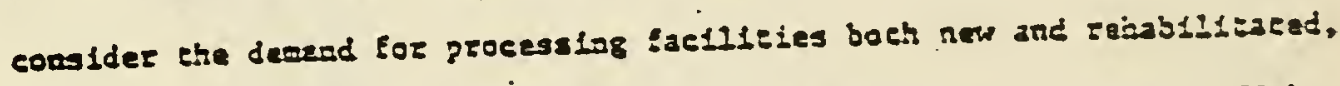

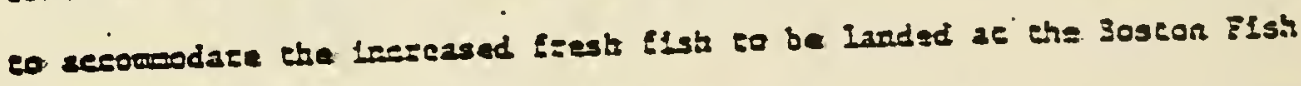

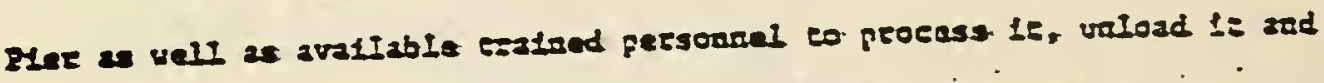
prepase it for shipeent. Sald iutbortey ahall also consider the escoeple

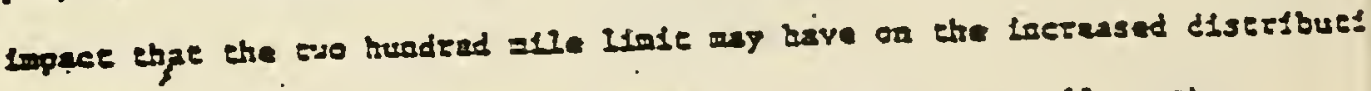
of fresh fisb out of the varfour Massachusetes portes as zall 23 the

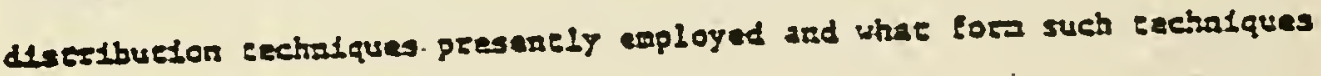


Eay take io the future: Sald Authortty shall also constder the possible effect and lmpact of any ofl splils or relaced damages within the two hundred alle lialt upon the fishezy facllities located at the vartous ports of the conosidealth. Sald Authority shall also considar chapte: eleven hundred and four of the acts of nfaecen hundzed and serency-one, relative to exceadfag the lateral boucdaries of the cotmontrealth dra:n seauard to a distance of fro hundaed atles. Sald Authority shall also consider any 1ssues to dees nesessary fa order to properly evaluace the Impact of the new federal two hundred mfle flshing l1ate. Satd Auchorfty shall reporte to the general coure the resules of its invesefgation and study, and les recomendisfions, if any, togecher uith drafts of lezislation necessary to cargy fis reconendations lnto effect, by flling the sace with the elerk of the house of rapresercatives froc tife to $\mathrm{ELe}$, but shall file an anaul iepore no lacer than the lase bednesday of December, alneceen hundred and seventy-seven. -

House of Representartves, Fibruaty, 1977.

Zassed, - Speakar.

In Senace, Eebruary, 1977. , 1977. Approved,

Governor. 


\section{IHE EISHING INDUSTRY IN MASSACHUSETTS}

(Report prepared for the Massachusetts Legislature

by the Massachusetts Port Authority

November, 1977.) 
Preface

I. Descriotion of the Massachusetts Fishing Industry

A. Fish Harvesting

1. Location

2. Fishing Fleet

3. Operations

4. Eishermen

5. Prices

B. Imported Fish

C. Fish Processing

1. Fresh Fish Processing

2. Frozen Block Processing

D. Marketing and Distribution

II. History of the Massachusetts Fishing Industry

A. Pre-1900

B. $1900-1945$

c. $1946-1960$

1. Growth of Imports

2. Subsidization of Foreign Fleets

3. Decline in Tariff on Imported Fish

4. Fish Stick Revolution

D. $1961-1976$

1. Growth of Foreign Fleets on Georges Bank

2. Decline in Fishing Stocks

3. Impact on Domestic Fleet

4. Government Efforts to Aid the Domestic Fleet

III. Eishing Ports in Massachusetts

The Boston Fishing Industry

1. Trends

2. History and Development

3. Fish Pier Operations and Economic Impact

Other Massachusetts Fishing Ports 
1. Gloucester

2. New Bedford - Fairhaven

3. Provincetown

4. Chatham

5. Other Ports

IV. The 200-Mile Limit

A. Background

B. Description

C. Impact of the 200-Mile Limit

1. Immediate Impact

2. Long Range Impact

3. Impact of the 200-Mile limit on the Boston Fish Pier

v. The Fishing Industry: Prognosis for the Future

A. Role of Foreign Fleets and Investors

B. Ability of the U.S. Government to Enforce the 200-Mile Limit

C. Ability of the Domestic Industry to Respond to 200-Mile Limit Potential

1. Vessel Financing

2. Fresh vs. Frozen Fish

NOTES 
With the passage of the Fishery Conservation and Management Act of 1976 and implementation of the 200-mile limit which it mandates, there has been a resurgence of interest in the fishing industry. Recognizing the potential impact of the 200-mile limit on the fishing industry in Boston and in Massachusetts in 1976, the Massachusetts legislature passed a bill directing the Massachusetts port Authority to prepare a study "relative to aiding the stability and expansion of the searood industry in Boston". The Authority was directed to consider:

1) - the effects of the 200-mile limit on fisheries fished by Massachusetts fishermen, particularly those from the Boston Fish Pier;

2) - the demand for new fishing boats;

3) - the demand for additional fish processing facilities to handle the increased fish landed at the Boston Fish Pier;

4) - the posible expansion of presently underutilized species;

5) - the possible impact of offshore oil on Massachusetts fishing.

In undertaking this study we have recognized that there is a large volume of work ongoing in this area; particularly on the part of the 200-Mile Fisheries Work Group coordinated by the office of the Lieutenant Governor. Rather than duplicate the work of other groups we have compiled and summarized ongoing research and survey efforts to provide the interested reader and policy maker with a complete introduction to the fishing industry in Massachusetts and the issues it faces. The extensive bibliography will allow those interested to pursue particular subjects in more detail.

This report has been prepared by the staff of Massport's Planning Department under the supervision of Planning Director, Catherine Donaher. Gail Monahan was principally responsible for interviews, data collection, and writing the first draft of the report while an intern at Massport. Anne Aylward edited and wrote later drafts of the report. We are grateful to members of Massport's Marketing and Maritime Departments for their comments and suggestions. We are particularly grateful to Hugh O'Rourke, Executive Secretary of the Boston Fisheries Association, for his wiling contribution of time and information and many helpful suggestions. 

What is commonly referred to as "the Massachusetts Fishing Industry" is in fact an extremely complex and highly fragmented sector of the economy - an array of inter-related parts each with its own actors and issues. In this section the various components of this complex industry and their operations are described.

There are two basic components of the fishing industry which must be considered: harvesting and processing. While the two are historically closely linked, their relationship has changed significantly in the last twenty years. During this period the total employment in fish harvesting and fish processing has remained relatively constant in Massachusetts (about 5,000 jobs); however, an increasing proportion of these jobs, has been in processing rather than in fish harvesting. The link between these two sectors of the industry, and the link between the domestic and foreign fish harvesting operations are important aspects of the fishing industry.

Traditionally, there has also been a close geographic link between harvesting and processing fish. However, this link has become weaker as the share of U.S. consumer seafood caught by the U.S. fishing fleet declined. U.S. processors now handle primarily imported fish trucked from Canada or shipped as containerized freight through U.S. ports. If this switch to foreign imports continues processors may move closer to foreign suppliers or regional distribution centers, the historical geographic link between harvesting and processing may disappear and seriously effect the employment and economic balance in smaller fishing ports.

\section{A. Eish Harvesting}

(1) - Location: New England's coastline parallels the southern end of a continental shelf which extends for one thousand miles along the Northwest Atlantic Coast from Newfoundland to Long Island. Eighty species of edible fish and shellfish can be found in the waters within three saling days of the principal ports of New England. Eight or nine species of groundfish (those which feed on the ocean floor) have historically made up the bulk of the catch. Most important are haddock, flounder, cod, ocean perch, whiting, and bake.

Georges Bank, part of this continental shelf, is one of the most productive fisheries in the world. The fish on Georges Bank are a renewable resource that can provide high protein food as long as the resource is well managed. However, the commercially important species on the Bank are presentiy over 3 exploited, having been over fished for a decade or more. ${ }^{3}$ It is expected that effective enforcement 

of the quotas established under the 200-mile limit legislation in 1976 will allow stocks to regenerate.

(2) - Fishing Fleet: 404 fishing vessels operate out of the major Massachusetts ports of Boston, Gloucester, New Bedford, Provincetown and Chatham. $80 \%$ of U.S. fishing vessels are individually owned and operated. $84 \%$ are under five tons. They are old ships, averaging 28 years of age. The typical Massachusetts vessel is a moderate sized trawler between 65 and 100 feet in length and powered by 300 to 700 horsepower engines. The great majority of the groundfish caught by domegtic fishermen on Georges Bank is captured by such trawlers. (In 1974 the proportion was 93\%).

The cost for a new trawler is $\$ 500,000$ to $\$ 1,000,000$. High profit boats, at present, are generally moderate sized vessels which can be operated by small crews, achieving nearly equivalent revenues to the larger trawlers at a lower cost. Due to depleted fishing stocks, the larger vessels frequently are forced to return to port before capacity to prevent spoilage of their catch.

Various sources rate the useful life of a fishing vessel differently: the Internal Revenue Service allows depreciation over ten years; banks will mortgage new vessels for upwards of twelve years; federal guarantors will allow fifteen years for mortgage amortization; and the shipping industry estimates a twenty year life-span for an adequately maintained vessel. Gonstant refitting may stretch this to thirty years at most.

This creates an atmosphere in which individual owners must choose, after some years in the industry, either to re-invest in a ship at high expense or to leave the industry. Figures show that whatever the dynamics, the fleet remained stable throughout the last decade (1965-75) and that fleet expansion did not occur in anticipation of the 200-mile limit.

However, the increased catch since March lst has resulted in a sharp increase in boat construction. In october 1977 Forbes Magazine reported that 35 new commercial fishing vessels are being built for the New England fleet, at least three times as many as have entered the fleet in the past two years. The vessels being constructedoare two to three times as large as the traditional trawler.

Large trawlers ( 120 feet and up) are generally owned by fleet owners. In Boston (which has historically accounted for the greatest number of large trawlers in Massachusetts and New England) those fleet owners have been large fish processing firms. As these firms have switched from fish caught by domestic fishermen to fish imported from foreign vessels, large trawlers have also declined from 59 in 1947 , 


\section{FIGURE 1}

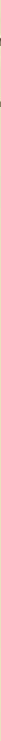

LARCE MODERV STERV TRAWLER

Source: Effects on Comercial Fishing of Petroleum Develooment oIf the Northeastern United States, Woods Hole Oceanographic Institute, ApIII 1976. 



\section{FIGURE 2}

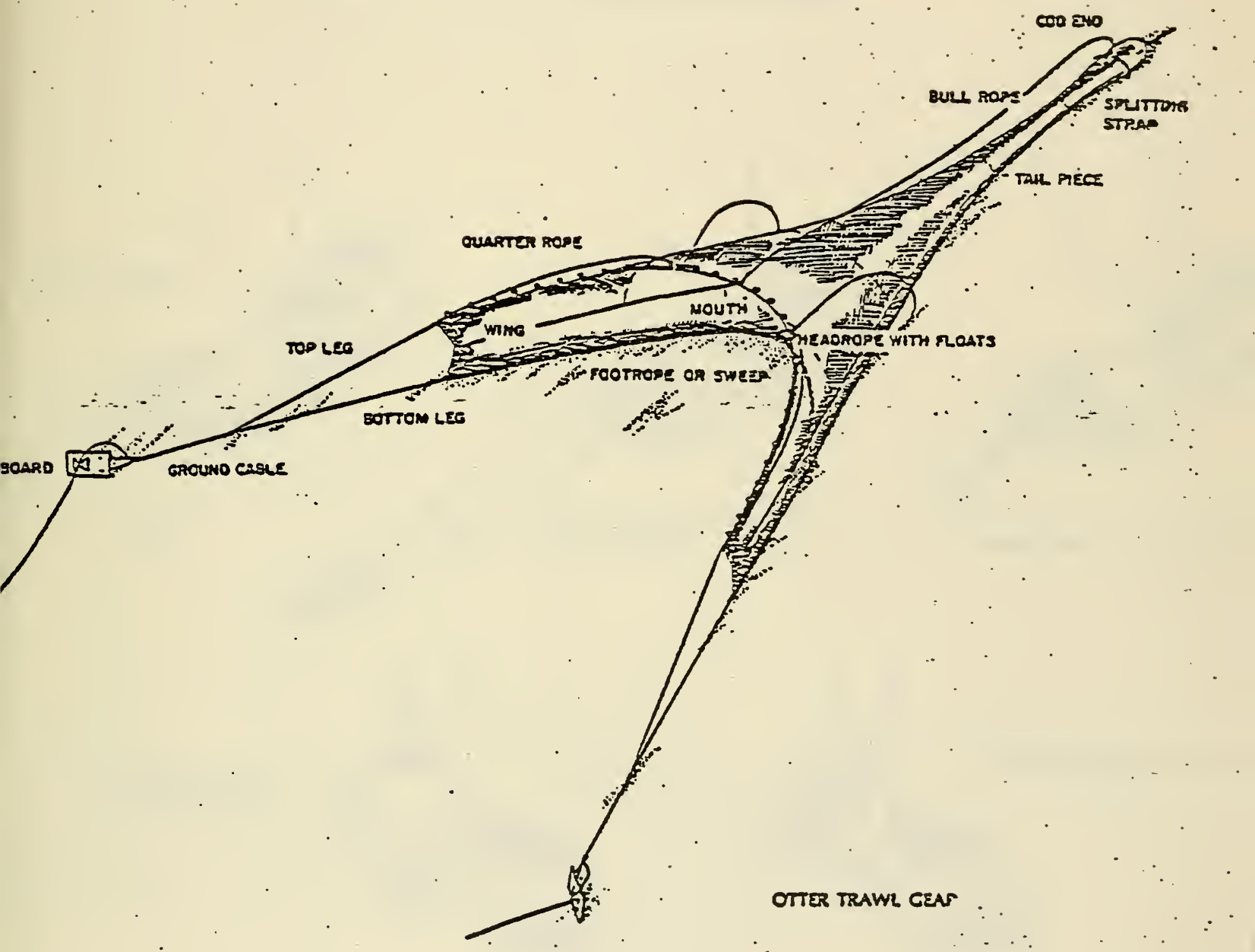

Sounce: Effects on Commercial Fishing of Petroleum Develoment off the Northeastern Lnited States, Noods Kole Oceanographic Institute April 1976, 
FIGURE 3

HALILBACK - WESTERN RICGED STERN TRAILER

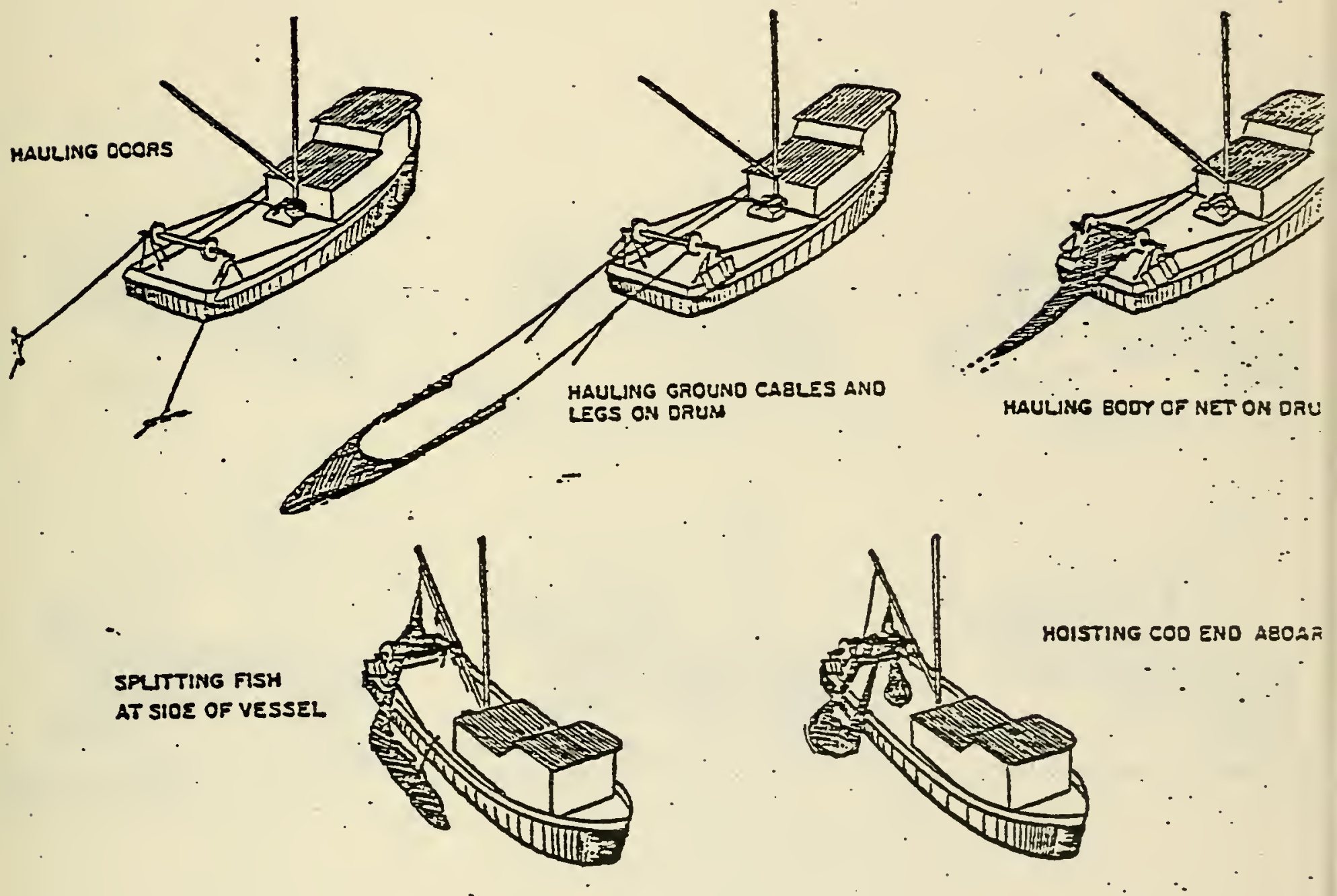
Northeastern United States, Woods Hole Institute, April 1976. 


to 9 in 1971.11

(3) eperations: Groundfish vessels (Fig. 1) spend an average of 153 days per year at sea, an average trip lasting four to seven days depending on the weather, the success of the fishing and the distance of the fishing grounds from port.

The fishing vessel trawls up and down on a parallel course, hauling in the nets at approximately $11 / 2$ to 2 hour intervals. Under good conditions 1,000 to 3,000 pounds of fish may be taken in one haul. The vessels use otter trawls, (Fig. 2), a flattened funnel of webbing which is towed over the seafloor behind the vessel, scooping up fish which live $13^{n}$ or just above the bottom - thus the term groundfish. 3 This procedure is illustrated in Figure 4 for stern travelers and Figure 5 for side trawlers.

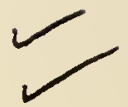

The caught fish are gutted on board the vessel, reducing the weight of the fish from its "round" weight to its "landed" weight. The fish are then sorted and stored in ice in pens in the hold of the vessel.

Once at port "lumpers" (members of the longshoremen's union) unload the fish, using pitchforks, into baskets which are hoisted up to the dock and dumped into crates, barrels, chutes, or carts. At this point the product is further sorted, de-iced and weighed.

(4) Elshermen: Over the years the legendary yankee fisherman has given way to a more varied ethnic group. In New England distinctive sub-cultures have evolved at the various fishing ports. The fishermen of provincetown are predominantly Portuguese-Americans, Gloucester's boats are manned by Italian Americans, New Bedford is dominated by men of Canadian, Portuguese and Norwegian heritage, and many of Boston's fishermen emigrated from Canada's Maritime Provifees during the depression following the first World War.

Fishermen work six hours on, six hours off seven days a week while at sea. Their earnings have increased in recent years as the size of the crew has decreased and the price of fish has risen. On the average a deckhand can now expect to make $\$ 2 P_{5} 000$ a year while a skipper can make up to $\$ 35,000$. $\$$ This would be based on a minimum of twenty-five ten day trips a year. The typical trawler now has six to eight crew members. Ten years ago the same vessel would have had a crew of fourteen to sixteen men.

Fishermen work under a "lay" arrangement. Each fishing trip is a joint venture between the vessel owners, captain and crew. From the gross profits of the trip are deducted certain expenses: the cost of wharfage, auction fees, cost 
(3) eperations: Groundrish vessels (Fig. I) spend an average of 153 days per year at sea, an average trip lasting four to seven days depending on the weather, the success of the fishing and the distance of the fishing grounds from port.

The fishing vessel trawls up and down on a parallel course, hauling in the nets at approximately $11 / 2$ to 2 hour intervals. Under good conditions 1,000 to 3,000 pounds of fish may be taken in one haul. The vessels use otter trawls, (Fig. 2), a flattened funnel of webbing which is towed over the seafloor behind the vessel, scooping up fish which live $g^{n}$ or just above the bottom - thus the term

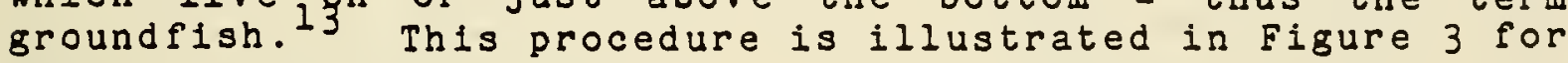
stern travelers and Figure 4 for side trawlers.

The caught fish are gutted on board the vessel, reducing the weight of the fish from its "round" weight to its "landed" weight. The fish are then sorted and stored in ice in pens in the hold of the vessel.

Once at port "Iumpers" (members of the longshoremen's union) unload the fish, using pitchforks, into baskets which are hoisted up to the dock and dumped into crates, barrels, chutes, or carts. At this point the product is further sorted, de-iced and weighed.

(4) Eishermen: over the years the legendary yankee fisherman has given way to a more varied ethnic group. In New England distinctive sub-cultures have evolved at the various fishing ports. The fishermen of Provincetown are predominantly Portuguese-Americans, Gloucester's boats are manned by Italian Americans, New Bedford is dominated by men of Canadian, Portuguese and Norwegian heritage, and many of Boston's fishermen emigrated from Canada's Maritime Provifoes during the depression following the first World War.

Fishermen work six hours on, six hours off seven days a week while at sea. Their earnings have increased in recent years as the size of the crew has decreased and the price of fish has risen. On the average a deckhand can now expect to make $\$ 2 \rho_{5} 000$ a year while a skipper can make up to $\$ 35,000.15$ This would be based on a minimum of twenty-five ten day trips a year. The typical trawler now has six to eight crew members. Ten years ago the same vessel would have had a crew of fourteen to sixteen men.

Fishermen work under a "lay" arrangement. Each fishing trip is a joint venture between the vessel owners, captain and crew. From the gross profits of the trip are deducted certain expenses: the cost of wharfage, auction fees, cost 
of weighing scales. What remains is referred to as the net stock and of this, $60 \%$ is allotted to the vessel owners and 40\% to the crew members. From the crew's share the cost of fuel, ice, groceries and labor at dockside is deducted. A $10 \%$ bonus for the skipper is deducted from the owner's share. In the event the fishing trip does not register a profit the vessel owners guarantee the crew members a minimum wage of $\$ 15$ per day.

Earnings of fishermen are unstable; they fluctuate from trawler to trawler, from trip to trip and from one season to the next depending on fishermen's luck the skipper's smell for fish, the operation of the vessel and above all, the price of fish.

Over the years, the Atlantic Fishermen's Union has sought to maintain some control over prices for landed fish. In a landmark decision in the late 1940's, however, the Massachusetts courts ruled that efforts to restrict landings and other tactics to force processors to pay higher prices were violations of the Commonwealth's anti-monopoly act. The court ruled that fishermen's efforts to increase their earnings must be restricted ta negotiations with the boat owner on whose boat they fish.

Since fisherman's wages are tied to the earnings of the boat, fishermen employed on the newer, more productive boats earn substantially more than their counterparts on the less productive, older vessels. Thus, average wage levels may be somewhat deceptive when used to judge the attractiveness of the fishing industry. This is particularly important because new entrants into the fishing labor force must serve on the marginal vessels to gain experience before they can obtain a berth on a newer, more productive boat. This compounds $18^{\text {the }}$ problem of attracting younger men to the industry.

(5) Prices: Because fish landings fluctuate greatly, prices also vary widely. On days when a number of trawlers come into port at the same time, haddock landed may run as high as 25,000 pounds at the Boston Fish Pier. When volume is high, prices tend to become depressed. On other days landings fall as low as 500 pounds or none at all, low volume pushes the price back up again. Each time a boat lands catch, the captain takes a chance on the market. If a number of boats land at the same time the price drops. If his is ithe only boat in port that day the price will be higher.

The instability of both volume and price is an important characteristic of the domestic fishing industry. This classic example of pricing based on supply and demand creates severe problems for fishermen, boat owners, and processors. 
Another factor affecting the pricing of fish in $N$ w England is imported fish. Over $60 \%$ of the fish consumed in the U.S. is now imported. Truck deliveries of imported fish to Boston tend to depress the market for fish landed locally. For example, cod normally $\$ .37$ a pound will drop to $\$ .20$ a pound on some days begause of foreign imports trucked over the road from Canada. More than half of the fish processed in Boston is brought to the Fish Pier by truck.

In addition to this fresh fish which is trucked in, frozen blocks of fish imported through the ports of New York and Gloucester and through Moran Container Terminal in Boston are also trucked to the Boston Fish pier for processing. This frozen block fish competes less directly with local landings since it is the raw material for frozen fish processors while the domestic fleet fishes primarily to meet the demands of the fresh fish market.

A sizable quantity of the fish imported to the United States from Canada is not caught by Canadian vessels, but imported from other nations. Foreign fishing vessels use Canadian ports to land fish for U.S. processors because U.S. law prohibits landing at U.S. ports of fresh fish caught on any but U.S. built and manned vessels.

The islands of St. Pierre and Miquelon off the coast of Newfoundland are free ports which are often used for landing fish. Their free port status means that any nation can land fish there duty free and then export duty free to any port in the world. Poland, West Germany, Portugal, and Spain are the major countries landing fish here. A large portion of these landings are sent processed or whole to Canada, especially the port of Halifax. Once in Canada, the fish may be further processed or sent directly to the U.S. by boat, ferry, truck, or rail. Although specific numbers are not avallable concerning these imports, reliable sources say that up to $25 \%$ of our Canadian imports may originate at st. Pierre and Miquelon.

\section{c. Fish Processing 22}

There are two basic types of processing: fresh and frozen. Fresh fish processing is labor intensive, requiring skilled workers for the cleaning, filleting, and.cutting of the fish. Frozen fish processing is highly automated with conveyor belts, automatic cutting devices, quick cutters and freezers.

Most fish processors run small operations. Only $17 \%$ have annual sales over $\$ 12$ milion, while over half have annual sales under $\$ 100,000.23$ of the 226 processing plants 


\section{FRESH FISH PROCESSING}

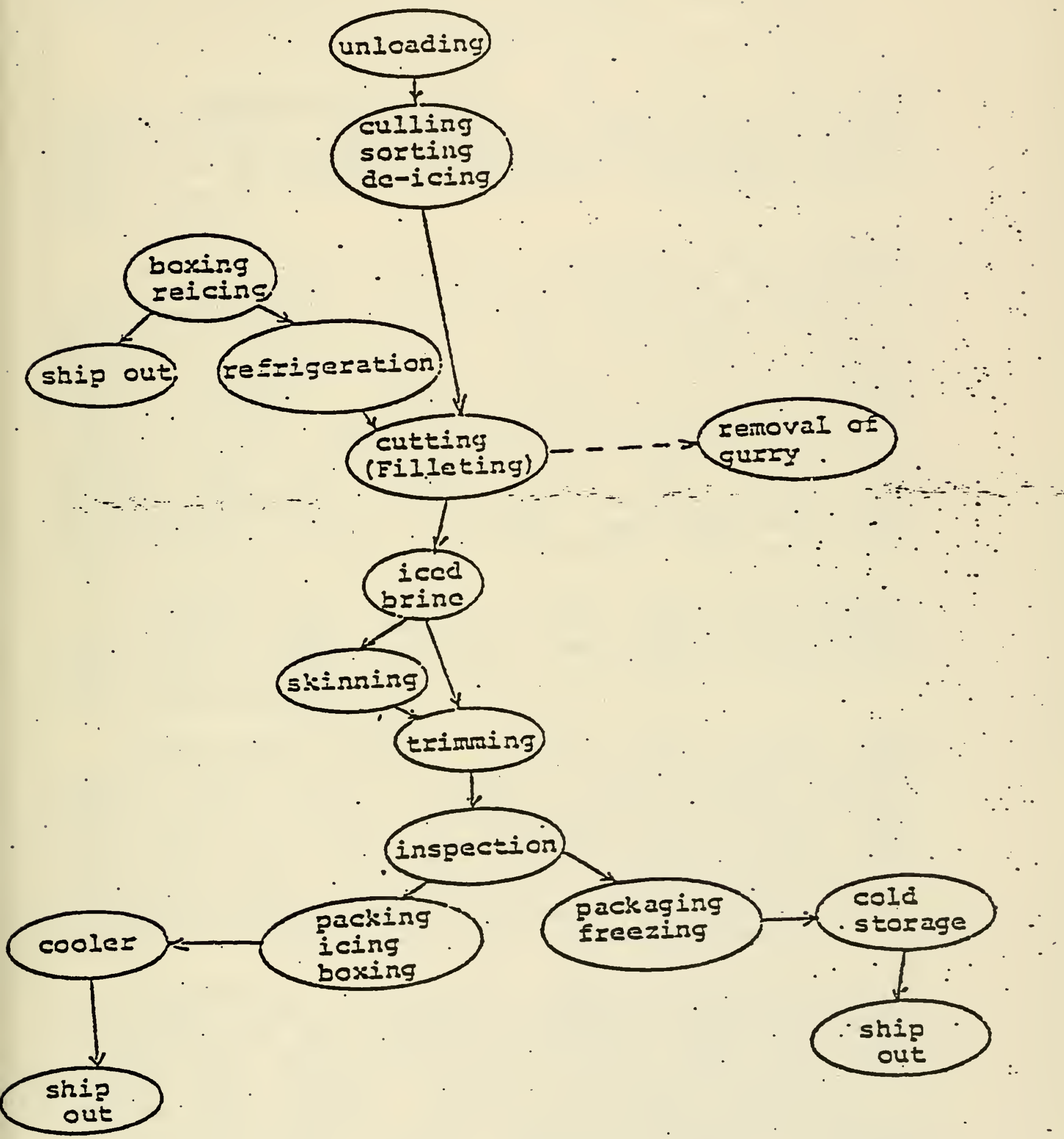

Source: Ustag Co-opefitives to Aid the New England Fising Industry, MIISG 

in New England, 159 process fresh fish, 75 process frozen fish, 21 process canned fish and 7 cure fish. However, the frozen fish processors produce a much greater volume of fish - nearly four times the value of processed fresh fish.

These two types of processing are described below:

(1) Eresh Fish processing: The typical fresh fish processing plant in New England is a single line production filleting plant. These plants are small and often located directly on or adjacent to the pier. The average size of such a plant is about 10,000 square feet for both processing and filleting.

Figure 5 illustrates the procedure in a typical filleting operation. After entering the plant the fish may be re-iced and boxed for storage or shipping or they may go immediately to processing. The labor for a filleting operation consists of a foreman, floormen, cutters, skinners, trimmers, weighers and packers. The equipment might consist of skinning machines, various conveying equipment, brine tanks, filleting machines, cutting boards, packing machines, ice crushers and coolers. Filleting of flounder and large haddock is best done by hand, but filleting machines are sometimes used for scrod. The end products - fillets and steaks - are packed and trucked daily to dealers, wholesalers, supermarkets and restaurants.

Alternatively, the fresh fillets may be packaged and quick frozen. With declining local catches and economic incentives for local fishermen to sell their product fresh, (at a higher price), most fresh fish which is packaged and frozen has been imported from Canada by truck.

Fish cutters belong to a seafood workers union. They make $\$ .00$ an hour and are guaranteed forty hours of work a week. Fish can be filleted at a rate of about 200 fish per hour per cutter and the skinning machine can skin about 2000 fillets per hour. These figures would suggest about ten cutters per skinning machine for efficiency. Three trimmers/packers are needed per skinning machine. An efficient operation usually requires a total of 15-20 people per line, including machine operators and floormen.

The small fish processors that deal with fresh fish have been content to continue to supply traditional markets - "gourmet and white-napkin" restaurants and fish retail stores - with high quality fresh fish. Since this demand remains high, existing processors feel little pressure to develop new markets. Given the narrow preference of American consumers for a few species, the processors' goal is to supply these species even when domestic fishermen cannot land a sufficient supply. At these times processors import fish, particularly cod and haddock, over the road 


\section{FROZEN FISH PROCESSIVG}

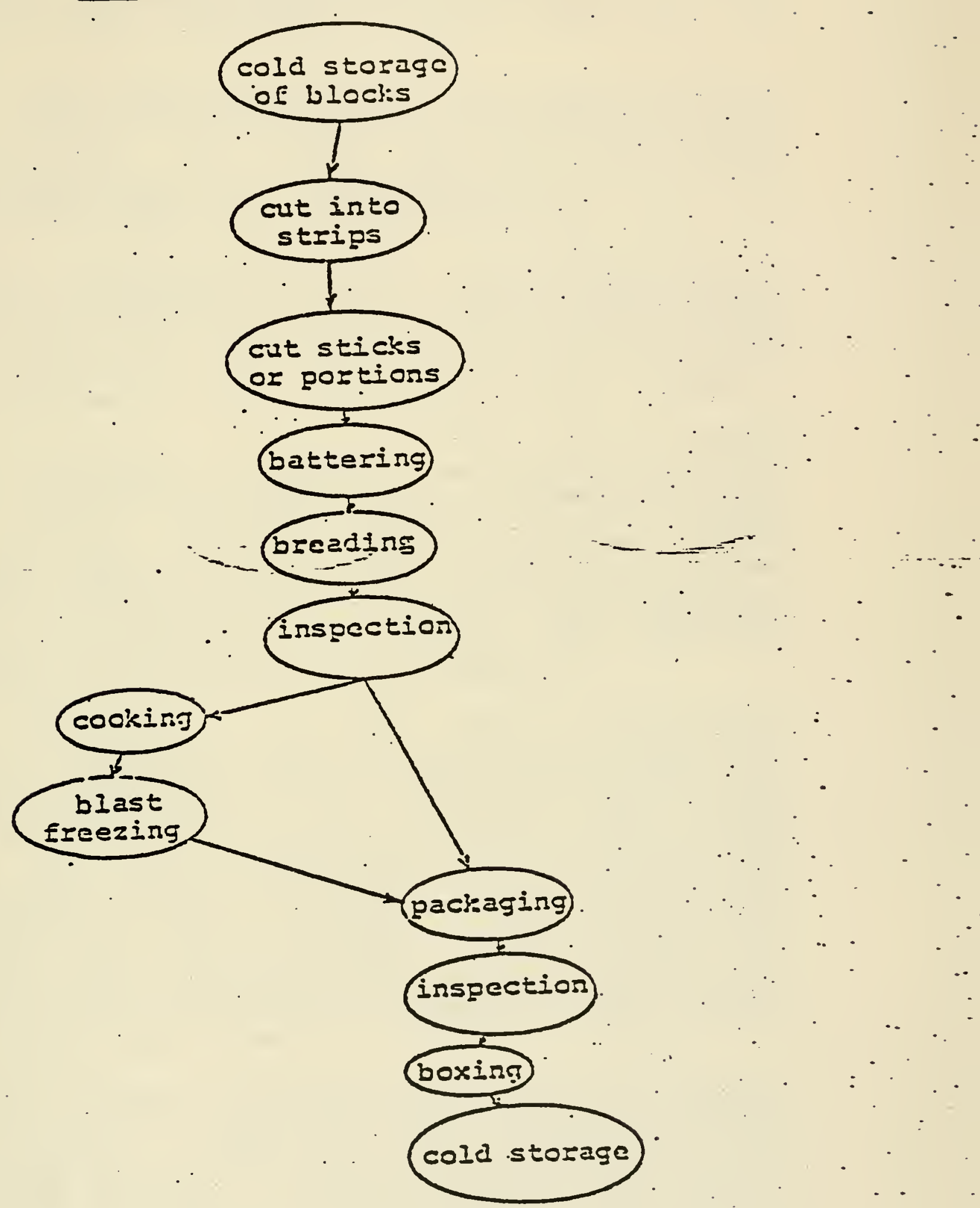

Source: Using Co-operatives to Atd the New EngIand Fishing Industo, BIISG 75-7, pg. 198. 
from Canada. The processing companies depend on Canadian fish to guarantee the constant supply of fish they require to maintain smooth production, a steady labor force, and dependably available product.

(2) Erozen Block Processing: Processing of frozen blocks of fish is the growing sector of the fishing industry in New England. This growth has resulted from the increasing popularity of processed fish (e.g. fish sticks) as well as the demand for fish products in inland areas where fresh fish prices are prohibitively high.

Blocks of frozen fillets provide the raw material for a convenience-type frozen fish sticks, portions, and dinners. A block is a huge mass of fish meat that has been frozen under presssure into a consistent block and can be neatly sawed into uniform portions. The dimensions of a block vary with manufacturer, but they normally weigh about 15 pounds.

These blocks of frozen fish are almost totally imported on large, refrigerated cargo ships. New Bedford, Boston and Gloucester all have some capability for accomodating these ships. However, Gloucester receives by far the bighest proportion of the shipments. Boston receives most of its frozen fish supplies from Gloucester and elsewhere by truck. one observer attributed this to more active solicitation on the part of Gloucester and calmer labor relations (Gloucester has Amalgamated Meat Cutters (AFt-CIO) labor rather than ILA as in Boston and New Bedford).

The frozen processors have been aided by revised tariff policies in recent years which have generally lowered import tarifs and removed tariffs on fish products which still need processing, e.g., whole fish and frozen blocks. Tariffs are being reviewed at the present round of GATT hearings. The policy of encouraging whole fish entry works to the benefit of the processors, but not of the domestic fisherman whose product must compete with the subsidized and more efficiently fished imports. Despite these tariff incentives, the processing industry has in recent years experienced some instability and shortages of available imports, due to depleted stocks, decreased foreign catches and increasing. global demand.

Figure 6 illustrates the procedures in a typical frozen processing plant. Machinery used consists of forklift trucks, band saws, portion and stick cutters, batter and breading equipment, in-line cookers, in-line freezer tunnels and packing machines. Each production line requires approximately thirty employees with production output for an eight hour shift varying from 10,000 pounds to 25,000 pounds depending on the product. A plant might have up to eight production lines. Average employment for a frozen fish processing plant is around 150 . 


The block of frozen fish is cut into sticks while it is still frozen. Cutting is done in two stages. Band saws are used in the first stage to produce thin slabs of frozen fillets. In the second stage these slabs are cut into sticks by automatically fed guillotine-type cutting machines. From here the sticks or portions proceed to the battering and breading machines. Portions and sticks can be cooked in either continuous or batch cookers. Before packaging the cooked product, it must be refrozen. This is done in freezers where blasts of cold air are blown through the trays of the sticks and portions. If the product is sold uncooked it does not have sufficient time to thaw and passes directly from breading to packaging. The frozen products are next machine-packed into cartons, and sent to cold storage. This process produces high quality frozen foods which are sold to various types of wholesaling and retail establishments.

\section{Marketing and Distribution}

There are effectively two networks for the marketing and distribution of New England fish: one for frozen fish (fish sticks and the like) and the other for fresh and frozen filiets.

The frozen fish market is dominated by a number of large processors (the largest of which is Gorton's of Gloucester) which process frozen fish products for nationwide distribution to supermarket chains and fast food establishments. The organization and operation of this marketing and distribution network is not unlike that of other major corporate food operations - it is modern, large and highly capitalized.

The domestic fisherman and fresh fish processor, on the other hand, depends on a number of small retail outiets for the distribution of their fresh fish product. This market is characterized by its fragmentation (figure 7). Prior to the new trend of shipping fresh fish by air, the prospects for fresh fish market expansion were not favorable.

There is an overwhelming consumer preference for meat. In 1973 for example, Americans ate no more than 2.5 pounds of fish per person while consuming about 250 pounds per person of meat and chicken. When Americans do eat fish they choose from only a few species: traditionally cod, haddock, flounder and redfish. Since there is little demand for other species, processors specialize in these species which they know they can profitably market. As a result fishermen invariably receive lower prices for other species so they too concentrate on species which are commercially profitable. This cycle perpetuates the narrow range of species consumed in this country.

This specialization (which is carried to the point 
where each port is noted for a particular species) can cause severe economic dislocation when a particular species (such as haddock or flounder) is overfished, and fishermen are forced to catch other, less-valued species for which a market has not been developed. As fishing by foreign fleets has increased in the past decade and the traditional species have been depleted, New England fishermen have been urged to consider the "ungegrutilized species": squid, mackerel, herring, and hake.

In a study done in 1964, Dorrel Nasho found that the demand for fish is relatively inelastic. 30 However, the price elasticity for individual species is very high, indicating that consumers will substitute one species for another in response to relative price changes. Other conclusions of the Nash study were that a consumer's fish preference declines absolutely as his income increases. In considering consumers' tendency to substitute fish for meat it was observed that while some substitution does exist the percentage increase in fish consumption is less than the percentage rise in meat prices. In other words other forms of substitution, such as eggs, poultry, and vegetarian dishes, are being made. Thus in 1964, the U.S. market for fresh fish, while strong, was limited - both in size and in species.

The same study indicated that approximately half of the fresh fish from Boston is distributed to New England and an additional one third is sent to New York State. A survey is presently being undertaken among Boston fish processors to update this information.

After it is sold, most fish $3 l^{l a n d e d}$ by New England fishermen is distributed by truck. 31 However, due to the rising cost of fresh fish at the retail level it is becoming profitable to ship fresh fish by air. If this trend continues it obviously could result in an enormously expanded market, since it is the perishability of fresh fish that has restricted the market area in the past. Another area of potential growth is the development of a U.S. market for presently underutilized species. For example, the New England Fisheries Program is aimed at developing commercial markets for "underutilized" species. The target species red and jonah crabs, squid, herring, and ocean quahog - have been identified and a series of publications, which contais recipes incorporating these species, have been circulated. 

III. History of the Massachusetts Fishing Industry ${ }^{33}$

Fishing is one of the oldest Massachusetts industries. The early exploration and development of the region were spurred by the value of this natural resource. However, in a time of rapid social and economic innovation, the fishing industry has maintained many of its old ways. Fishing technology has changed little since the turn of the century when otter trawling replaced line trawling. Processing technology has seen few changes since the development of filleting and fast freezing in the $1920^{\prime} \mathrm{s}$.

Even as the domestic market for fresh and frozen fish products has grown, the capacity of the New England fishing fleet to fill the needs of the market has decreased. Problems of increased labor and operating costs for the boat owner, the difficulty of obtaining financing, and the 1792 law which requires those landing at U.S. Ports to purchase expensive American built vessels, all were disincentives to investments in the domestic fleet, and to investment in new technology.

While New England fishermen continued to fish in the traditional manner, other countries (principally Japan, East and West German, Russia, and Poland) developed modern fleets. Fish processors, especially those. with high volume business, found that domestic fishermen were no longer able to meet their needs and turned to cheaper foreign imports. The large volume of lower priced foreign imports has, in turn, further depressed the domestic groundfish market. This trend towards increased value of imported fish, particularly by the frozen fish processors has gathered speed in the last decade. At the same time, the volume of fish caught by foreign fishing vessels on Georges Bank has increased correspondingly.

This long term decline of the New England fisheries is not due to any one factor but rather to a series of circumstances. The decline is not a recent phenomenon, but is part of a trend which began 100 years ago as described below.

\section{A. Pre -1900}

The export of fish from New England to the markets of Europe began to decline about 1830 and by 1880 had ceased altogether. It has been suggested that this was the result of the demands of a rapidly growing American market as well as price competition from European fish.

In the late $1800^{\prime} \mathrm{s}$ the American market for $N e w$ England's fish (primarily salted) shrank as fisheries on the West coast and in the Great lakes region grew and as beef and other meat products became readily available, replacing 
fish as a primary protein source. This resulted in a shift from salted to fresh fish and a shift in focus from a national to a regional market.

B. $\quad 1900-1945$

Major technological changes took place early in the twentieth century which transformed the fishing industry in New England. The introduction of otter trawlers, steam powered vessels which trawl with a net rather than with lines, dramatically increased each vessel's catch of fish. It became economical to make shorter trips, allowing the sale of fresh (rather than salted) fish.

Steam-powered vessels reduced the significance of the sea distance from fishing ground to port and commercial advantage shifted to ports which were also market and transportation centers such as Boston.

In 1922 Clarence Birdseye of Gloucester developed a process for quick freezing fish that immediately replaced salt curing as the means for preservation. Quick freezing used in tandem with the technique of filleting fish developed in 1921 revolutionized the fish business, giving rise to entirely new markets which had been beyond the reach of fresh fish. For example, an extensive market was created in the Midwest for "ocean perchn a marketing term for frozen red-eye fish fillets.

Innovations were also taking place in the processing of fish. In 1921, Dana Ward, a Boston fish dealer, introduced the process of filleting. At the outset, haddock provided nearly all of the industry's fillet output. However, more than a dozen other species have gradually become popular. Filleting had major repercussions on the marketing of fish. It resulted in "branded" packaging of fish - the differentiation of dealers and products ang the sale of fish by food stores other than fish retailers.

The years of World War II were profitable for the New England fishing industry. With the fishing fleets of most other Atlantic fishing nations out of action because of the war, and as a result of war-time food demands, the fish was unlimited. Government contract buying of fish during the war resulted in a price stability never experienced by the industry'previously without a guaranteed government market.

\section{C. $\quad 1946-1961$}

In 1943 American production of groundfish fillets exceeded imports by five times. By 1974 the imports from foreign suppliers were 13 times greater than the American catch. This dramatic shift can be explained by the events of the $1940^{\prime} \mathrm{s}$ and $1950^{\prime} \mathrm{s}$. 
Government contract buying of fish ended with the war and wild price fluctuations resumed with the disappearance the guaranteed government market. Fishermen were once again dependent on highly elastic consumer demand. Prices dropped 20\% as operating cots soared as a result of post war inflation. In an effort to stabilize prices in the late 1940's the Atlantic Fishermen's Union used a variety of approaches directed at constraining the supply and forcing dealers to raise fish prices. Responding to dealer protest, the Commonwealth of Massachusetts determined that the fishermen were in violation of the state's anti-monopoly act. Fishermen were told that they must bargain with the boat owners instead of the dealers. The dealers were thus insulated from price confrontations with the fishermen's union.

\section{(1) Growth of Imports}

During the late 1940's a growing volume of fish began to enter the New England market from Canada and Iceland. The pre-war market dominance by the domestic fishing fleet vanished. Pre-war domestic fishermen had supplied $95 \%$ of the domestic market. By 1948 their market share had slipped to $71 \%$. During this period the market itself had doubled as a result of population growth, improved transportation, and expansion of the sale of fish by supermarkets.

U.S. consumption again doubled from 1950 to the early $1970^{\prime} \mathrm{s}$. As fishermen attempted to limit the supply in order to get better prices, processors were trying to increase their output to meet the growing demand. During that period the catch of the domestic fleet remained relatively constant ( 2 to 2.5 miliion metric tons). The response of many processors was to turn to imported fish - either by buying into the Canadian processing industry with its lower wage non-unionized labor, or by buying imported fish to process at domestic plants. Imports have risen from 25\% to $60 \%$ of U.S. consumption. As a result a huge 5 rade deficit of over $\$ 1.5$ billion annually has developed.3 As domestic firms turned to foreign sources of supply, they isolated the domestic fleet from the volume fish market and further narrowed the market for the domestic catch.

\section{(2) Subsidization of Forelgn Fishing Fleets}

During the post-war period Canada, Japan and the nations of Europe were placing a high priority on the regeneration and modernization of their fishing fleets. Enormous government subsidies were invested in both fishing and processing equipment. Ironically, while the American fleet remained unsubsidized, much of the foreign investment was supplied by Marshall PIan funds from the U.S. Treasury. subsidy of foreign fleets by their home governments has continued. 
This subsidization resulted in rapid development of modern fishing fleets. The fleet subsidies and lower wage rates of foreign fishermen produced fish at prices considerably below those of the domestic fleet. A 1972 U.S. government study estimated that New England fishermen would have had to receive annual subsidies of the following dollars to equal the subsidies received by the foreign fleets:

$\begin{array}{ll}\text { Norway } & \$ 99.0 \text { million } \\ \text { Canada } & \$ 22.8 \text { miliion } \\ \text { Denmark } & \$ 11.8 \text { miliion } \\ \text { Japan } & \$ 2.1 \text { miliion } 36 \\ \text { Iceland } & \$ 1.0 \text { million }\end{array}$

The impact of these subsidies on New England fish prices is severe. A 1977 study estimated that subsidies on fresh fish fillets imported to the United States from Canada range from 22.9 to 32.8 Canadian cents per pound.

\section{(3) Decline in Tariff on Imported Fish}

Tariffs (customs duties levied by government on some items imported into this country) have historically been used as a tool to protect domestic industries against low priced foreign competition. Until 1939 the tariff on imported groundish served as this type of barrier to foreign countries. The duty ( $\$ .025$ per pound) effectively added 40\% to the cost of foreign fish. In 1939 the rate was reduced to the level of $\$ .018$ per pound for the first 15 militon pounds or 15\% of U.S. consumption for fish from Canada. This agreement was extended to other nations in 1948 and the rate of $\$ .025$ was "bound against increase". However, by this time the price of fish had increased substantially and the $\$ .025$ tariff added only $12 \%$ to cost, while the $\$ .018$ tariff added only $9 \%$.

Whole fish and frozen blocks of fish may be imported duty free. Processed fish, fresh or frozen, is subject to the tariff. These tarifis are presently being reviewed.

(4) "Eish Stick Revolution"

The other major development during the 1950 's was the introduction on the domestic market of frozen fish sticks and other convenience frozen portions of fish, both for home consumption and for fast food chains such as McDonalds. This market was even less profitable for the domestic pleet than the frozen fillets already being processed. However, the demand was readily met by foreign fleets which supplied the frozen blocks of fish needed for the new products. These blocks were first imported in 1953. By the end of 1954 blocks represented $40 \%$ of the total groundfish imports. 


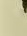


The importation of frozen blocks has continued to grow, increasing ten times by the mid-sixties while frozen fillet imports only doubled. Combined, these imports left groundfish caught by the domestic fleet supplying only $10 \%$ of the domestic market.

\section{D. $1961-1977$}

The trend of the 1950's accelerated during the 1960's as foreign fleets began to fish Georges Bank. From 1962 to 1972 total catch in the Northwest Atlantic doubled. Domestic fishermen, however, saw their catch decline by over 50\%. Haddock, the specialization of the Boston fleet, was particularly affected. Domestic catch fell from an average annual catch of 138 milition pounds from 1951-1962 to 16 milion pounds in 1975 .

The Massachusetts commercial fleet declined from 408 trawlers in 1962 to 343 in 1970 while the number of wholesalers and fish processors fell from 236 in 1960 to 201 in 1973. This trend was somewhat offset by growth in the frozen fish processing industry.

\section{(1) Growth of Foreign Fleets on Georges Bank}

Prior to 1961 most foreign fishermen had fished on the Grand Banks. Georges Bank, a smaller fishing ground 50 to 200 miles due east of Cape Cod, had been primarily the domain of American fishermen. Scarce resources on the Grand Banks led to exploratory voyages by foreigners to Georges Bank in the late 1950's. At this time Georges Bank offered underfished stocks of herring, mackerel, silver hake, and cod ideal for the intensive fishing of the high technology foreign fleets with their modern fishing trawlers and efficient factory ships. These fleets targeted on specific species and the entire fleet fished for one species until the catch rate became unacceptable, then the fleet would be redeployed to search for another concentrated stock of fish. This method of fishing by large fleets is known as "pulse fishing."

Soviet fishing trawlers were sighted off Cape cod for the first time in 1961. They were followed by Polish, East German, West German, French, Italian, Norwegian, Greek, Spanish, Japanese, Romanian, Bulgarian, Cuban, Mexican, Venezuelan, and Argentinian fishing vessels. These vessels were more modern and efficient than their American counterparts. With lower operating costs, they fished in direct competition with the domestic fleet. As a result, the catch of the U.S. fleet dropped precipitously.

The American fish processors, no longer dependent on the domestic fleet, were able to expand and profit from cooperation with foreign fishermen. For example, Gorton's 
of Gloucester contracted for Polish caught fish (even conducting an on-vessel training program for Polish fishermen). These fish were transhipped through the French held islands of St. Pierre and Miquelon to be processed in Gloucester. In 1974 Gorton's purchased a total of $s i x$ million dollars of Polish fish. 5.75 million dollars worth of fish was landed at the Boston Fish Pier during the same period.

Another example of this domestic/foreign cooperation was the 1970 contract between W.R. Grace Company and the Romanian fishing fleet under which Grace agreed to purchase the entire catch of Romania's new fleet of factory ships. The contract provided for delivery of two miliion dollars of frozen cod in 1972 and up to ten million dollars of fish by 1975. The cod was to be delivered to st. Pierre and Miquelon for transhipment to Gloucester.

Financed by this contract, the Romanians purchased a fleet of ten new stern trawlers from East Germany and poland to operate in direct competition with the under-financed American fleet. 38

It is instructive to compare these European fishing vessels with the typical trawler fishing from Boston which is 65 to 110 feet long and weighs an average of 150 tons. The fishing motor vessel Westermunde of the West German fleet (described in detail in a recent Atlantic article) is a combined stern trawler and processing ship, 311 feet long and 3556 tons. She is capable of catching and processing 250 tons of fish a day and has a crew of 60-70, half of whom are workers in the processing factory. The ship's highly automated processing operation includes cutting tables with continuousiy adjusting fillet knives which turn out 50-80 fillets a minute. The ship makes four voyages of $2-3$ months each year.

\section{(2) Decline of the Fishing stocks}

The most significant problem faced by New England fishermen today is the decline of fish stocks. Landings of fish and shellfish in New England have declined by more than one-half over the past fifteen years from 473 million pounds in 1960 to 150 million pounds in 1975. This decline, which began in the 1930 's, accelerated rapidly during the last decade with ffe arrival of the foreign fishing pleets on Georges Bank.

Initially the foreign countries fished only for herring and other species New England fishermen did not harvest. With continued expansion of the foreign fleets and construction of larger and more efficient vessels, few stocks of fish remained unexploited. By the mid-1960's, in order to harvest enough fish to maintain efficient 


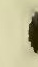


FIGURE 8

HADDOCK CAUGT BY U.S. AND SOVIET FISHITG FLEETS

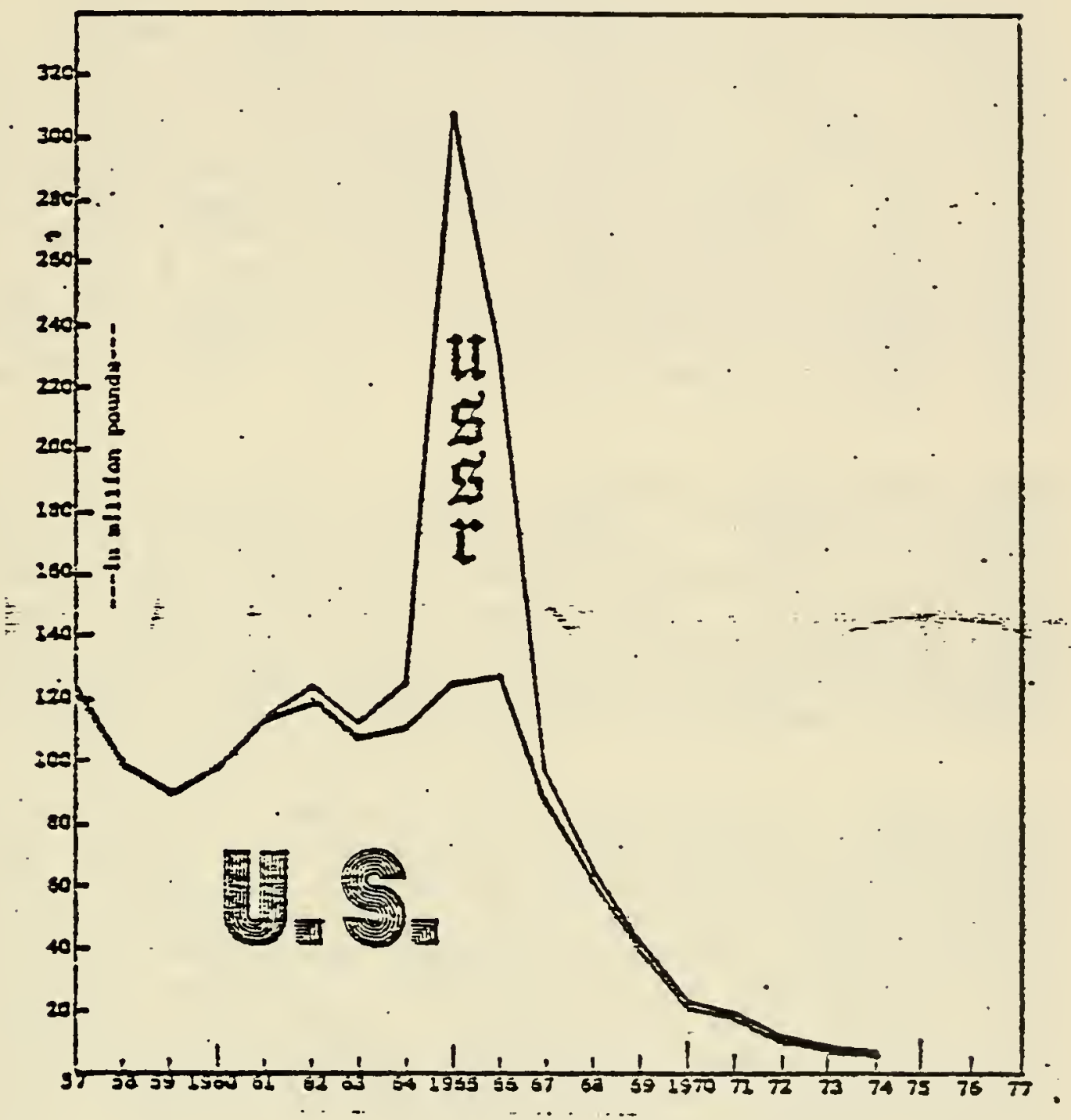

Source: David Boeri and James Gibson; TelI It Godd Bye Kiddo 
operations, the foreign fleets began to compete directly with New England's offshore fishing vessels. (Fig. 8)

The most dramatic example of this is haddock. In 1965 the soviet fleet began fishing the already heavily fished stocks of haddock, traditional specialization of the Boston vessels. For many years prior to 1965 New England fishermen had harvested an average of 120 million pounds of haddock annually. This is considered to approximate the maximum sustainable yield (the amount which may be caught without exceeding the nature reproduction rate of the fish). In 1965 the soviet began to pulse fish the haddock. Nine years later the baddock stock had declined to such a critically low level that a zero quota was established to protect the stock from extinction. 4 This progression is graphically illustrated in figure 8.4 Today scientists estimate the

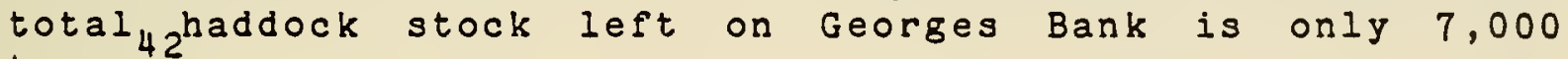
tons.

Although the catch of the domestic fleet has been declining over a period of forty years, its negative impact on profits occurred much more recently. This is because with technology improving, demand growing, and prices rising, each trip brought higher profits. Although their total annual catch was less, it came at lower costs and with higher absolute profits. Thus, the industry had no pressing economic reason to be concerned until landings by effort began to show diminishing returns.

Dependent on a resource not only limited in supply but subject to sudden, unpredictable fluctuations, fishermen traditionally have seen little need for stock regulation and managemt. As they perceived the situation, fish abundance or scarcity was due to the vagaries of nature rather than to man's abusive actions. Although the possibility of overfishing had been noted as early as 1918 by the U.S. Commissioner of Fisheries, and the actual effects of overfishing were becoming apparent by mid-century as productivity declined, the warnings went unheeded until the late $1960 \mathrm{\prime s}$. By then, many of the most valuable stocks, especially haddock 4 ând yellowtail flounder, were significantly depleted.

\section{(3) Impact on the Domestic Fleet}

As the fishing industry has declined, banks and corporations have been less willing to finance new fishing vessels. The average vessel in the domestic fleet is 28 years old, underpowered, undersized and ill-equipped to compete with the foreign fleet. The prohibitively high insurance rates results in most vessels presently being uninsured.

A 1792 law (46 U.S. Code 25) protects the U.S. 
fishermen by requiring any vessel landing fresh fish in the United States to be domestically built. This $\frac{1}{4} a_{4} \mathrm{~W}$ causes foreign fleets to tranship their catch via Canada.

\section{(4) Government Efforts to Aid the Domestic Fleet}

A number of government efforts designed to aid the domestic fishing industry have been enacted in the last 20 years. These have included providing loans for fishing vessels (1960's Fleet Improvement Act), establishing regulations on haul and gear of foreign vessels (ICNAF) regulations), and funding pier and harbor facilities. 


\section{Fishing Ports in Massachusetts}

The fishing industry (including harvesting, wholesaling and processing) is a major economic force in New England's coastal commulties. Such concentration makes these communities especially vulnerable to changes in the industry. The overall decline in groundfishifg has exacerbated unemployment in coastal Massachusetts. The major fishing ports in Massachusetts are Boston, Gloucester, New Bedford, and Provincetown.

\section{A. The Boston Eishing Industry.}

The Boston Fish Pier is the center of fish unloading, processing and distribution activities in the Boston metropolitan area. The pier itself deals almost exclusively in fresh fish: of the fifteen finfish dealers on the pier, ten deal in fresh fish only; of the five dealers that handle frozen fish only two attribute over one-third of the output to frozen fish. Frozen fish processors are located nearby along Northern Avenue. A survey undertaken in. March 1977 Indicated employment in processing firms of over looo people.

Boston historically has specialized in haddock, cod and flounder. While these remain the primary species, Boston fishermen and processors have expanded their scope in recent years, taking in other species such as pollock and hake.

\section{(1) Irends}

The landings at the Boston Fish Pier bave steadily declined since its peak years in the late $30 \mathrm{~s}$ when annual landings were over 300 million pounds. By 1961, according to the National Marine Fisheries Service of the United States Department of Commerce, landings at the port of Boston had fallen to 117 million pounds and ranked tenth in the list of "Landings at Certain U.S. Ports." By 1965 , Boston ranked eleventh with 104 million pounds landed and by 1970, Boston was in sixteenth place with only 32 million pounds landed. By 1976 landings had fallen off to. 23 milition pounds.

Boston's fishermen feel that this decine is primarily attributable to:

1) The lack of modern trawlers and equipment

2) The depletion of Georges Bank fish population by foreign vessels. 
Figure 9

EISH LANDINGS

(In Thousands of Pounds)

Year

1950

1960

1961

1962

1963

1964

1965

1966

1967

1968

1969

1970

1971

1972

1973

1974

1975

1976
Boston Fish pier

New England

$170,0001 \mathrm{bs}$.

$1,007,000$

108,000

852,000

115,000

116,000

105,000

106,000

101,000

702,000

88,560

77,016

59,563

45,708

32,157

451,000

32,048

21,772

489,000

23,685

25,165

452,000

21,994

497,483

23,316

Source: National Oceanic \& Atmospheric Administration

Eishery Statistics of the United States, Annual 
Recently, significant fleet expansion has been planned for the U.S. Forbes magazine reported that thirty-five boats are under construction for the New England fleet, and even more vessels are being refitted for use. Therefore, the problem of vessel shortage may well be alleviated in the near future. Processors have expressed interest in investing at the Boston Fish Pier if some government funds can be secured for rehabilitation, which would add modern processing facilitites.

On the fish supply side, the title of "declining industry" is slightly misleading in the case of Boston fish activity. In Boston during 1970, 32.2 million pounds of fish were landed by fishing vessels while 49.9 miliion pounds of fish were trucked into the city, resulting in area Fish Pien processors handing over 80 million pounds of fish. The 200-mile limit has increased landings in recent months.

\section{(2) History and Development}

Twentieth century expansion of Boston's fish business began in 1914 when the Boston Fish Pier, then the world's most modern, was opened. The Commonwealth of Massachusetts built the pier at a cost of 3.5 million dollars under terms of a 1910 agreement with the Boston Fish Market Corporation, a company which the Boston fish dealers formed to acquire a new location for the industry. Their old facilities on "T" Wharf, which they had occupied since 1884, had become unsanitary and inadequate.

The corporation spent a million dollars to construct buildings on the Fish pier and rented space to its dealers. In 1913 the nation's largest icing and cold storage plant was erected on the pier with the Boston Fish Market Corporation holding controlling interest.

The improved facilities, combined with technological advances, enabled landings to rise from less than 100 million pounds in 1914 to a peak of nearly 340 milion pounds in 1936.

In 1916 fish dealers on the pier combined into two competing holding companies, the Bay state Fishing Company and the Boston Fish Pier Company. Both holding companies made enormous profits during the First World War. In 1918 the Commonwealth of Massachusettts and the United States Government prosecuted this duopoly for promoting monopolistic practices and restraining trade. Seventeen prominent fish merchants wereffound guilty and received fines and prison sentences. The 
legacy of this court decision is the highly fragmented industry. of today.

Prior to World War II, the Port of Boston clearly dominated the New England fishing industry. Development of the ocean perch market brought Gloucester to the fore in 1944, but by 1964 long-term growth in New Bedford coupled with a decline in the other two ports had given New Bedford a slight edge in terms of total fresh fish landings. During 1964, landings of fish and shellfish in Massachusetts ports amounted to 410 million pounds, with 33 percent landed in New Bedford, 31 percent in Gloucester, 26 percent in Boston, and the remaining 10 percent at all other Massachusetts ports. Principal species landed were Plounder in New redfgrd, ocean perch in Gloucester, and haddock in Boston. In the 1970's Gloucester has taken the lead and has become a major center for frozen processors.

The Pier was operated privately until 1972. In that year the operators of the Pier, the Boston Fish Market Corporation sold the lease to the Massachusetts Port Autbority.

The Pier is 1200 feet long and 310 feet wide and holds four buildings: Buildings 1 and 2 house the majority of the fish processors in the area. The New England Fish Exchange is located in Building 3 at the end of the pier. Building 6 , at the Northern Avenue end of the pier, is unused except for the boilers which provide steam for heating $50^{\text {and }}$ hot water to all five buildings of the facility.

Boston is the hub of the regional transportation network and has deep water and pier facilities able to handle any refrigerated cargo ship or fishing vessel. Its location is ideal for recelpt of imports from Canada, Iceland and Northern Europe.

\section{(3) Elsh Pier eperations and Economic Impact}

The overall decline in the industry has been reflected in a decline in the size of the Boston fishing fleet. In 1965 there were 59 fishing vessels operating at the Fish Pier. In 1976 there were fifteen. The two newest boats wej le built in 1968 at a cost of 1.8 million dollars each.

Fishing boats are generally berthed at the northern end of the pier when unloading. Lumpers (longshoremen) and fishermen unload the boats. An auction is beld every week day morning at $7: 15$ in the New England Fish Exchange. All fish landed at the pier 
are sold at the auction, at prices set by the New England Fish Exchange. Price bidding appears to be competitive, although the distribution of each day's catch appears to be subject to some preagreement. Processors on or near the pier, along with other buyers who own a seat bid for the fish. Boston buyers do not bid for entire boatloads, as in New Bedford, but for smaller quantities of specific species. Fish are sold in units called scales (1,000 pounds). The processors on the pier buy a large portion of the daily landings, some fish is trucked to processors on nearby Northern Avenue; and the remainder goes to large retail establishments.

After the fish is sold at the auction it is packed into carts at dockside and the carts are weighed and towed by small tractors to the processors.

Fish processors on the pier and on Northern Avenue have filleting operations that produce fresh and frozen fillets. Fish landed at the Fish pier was once the primary supply for these processors. Landings at the pier are no longer sufficient to meet the needs of the domestic market and thus the processors. Less than half of all fish processed at the Fish Pier is landed by boat. The rest is imported fish brought in "over the road" from Gloucester and Canada.

Frozen fish processors on Northern Avenue receive an even greater part of their supply as imports than do processors of fresh fish. This fish is imported in frozen blocks, either through the ports of Boston and Gloucester, or by truck from Canada.

\section{B. Other Massachusetts Fish Ports}

The other three major fishing ports in the Commonwealth are Gloucester, specializing in ocean perch, silver hake and sea herring, New Bedford, specializing in yellow flounder and scallops, and Provincetown which brings in plounder, cod, and scallops. Descriptions of these ports and others in Massachusetts are ejxcerpted from the $200-M i l e$ Work Group's Fish Report: ${ }^{2}$

(1) Gleucester whose fleet has traditionally concentrated on fishing of ocean perch, silver hake and sea herring, harbors a fleet of 10-20 off-shore trawlers plus 60-65 small trawlers, draggers, gilinetters and line trawlers. Gloucester is a major port of entry for imports of frozen fish blocks and has become a very large frozen fish processing center. With increased catch under the 200-mile jurisdiction, the frozen fish processing industry could be expected 


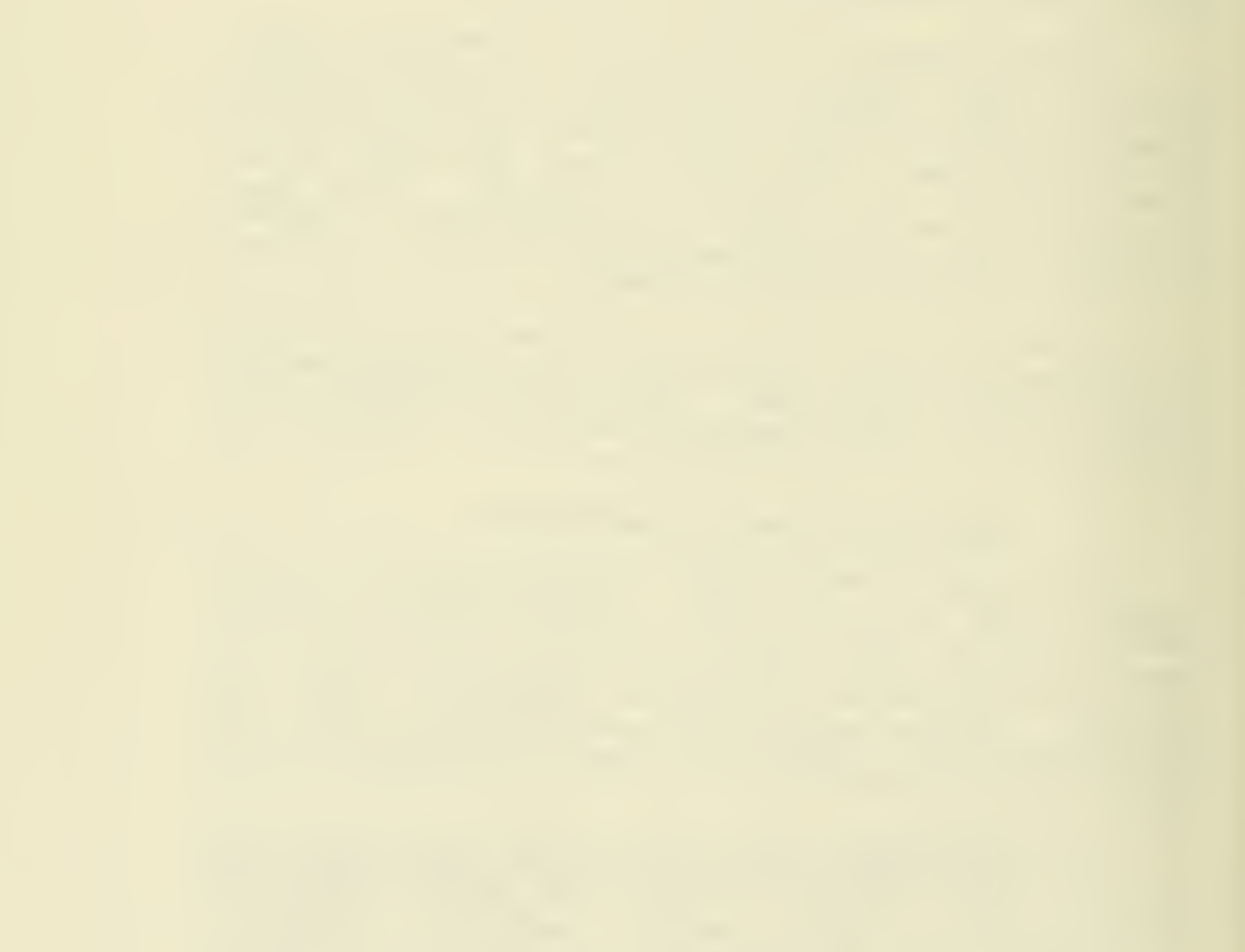


to rely more heavily on domestic landings for supply. The refrigerated warehouses on the Inner Harbor have a combined capacity for storing 100 million pounds of fish. This should adequately serve the possible growth in Massachusetts landings. Gloucester's second waterfront urban renewal project, covering 43 acres at the head of the North Channel, envisions new wharves and piers for the fishing fleet and a new fish processing and cold storage plant. Further redevelopment along the harbor could provide additional docking space for the fishing fleet and space for expanded processing operations.

(2) New Bedford-Fairhaven has a fishing fleet composed of approximately 155 otter trawlers and 16 scallopers. The fleet has traditionally concentrated on flounder and sea scallops. Frionor Kitchens is the only large frozen fish processing plant in New Bedford. The processing of fresh fish is the mainstay of the $\mathrm{New}$ Bedford fishing industry. Over the past several years substantial improvements to the harbor facilities for the New Bedford fishing industry have been undertaken and are nearing completion.

The fresh fish processing industry has been relocated in the new south Terminal with its 1600 foot marginal pier, two thirds of which faces a 30-foot deep channel and one-third faces a 20-foot deep channel. The South Terminal presently includes facilities for garaging trucks used to transport fish products. Some 24 acres are still unoccupled and could provide space for expansion of the fish processing industry. In addition, the New Bedford Redevelopment Authority is rehabilitating four piers (Leonards Wharf, Homers Wharf, and Piers No. 3 and 4 ) for use by the fishing fleet. These improvements ensure that New Bedford will be in a position to take advantage of opportunities open to the fishing industry under extended U.S. jurisdiction.

(3) Provincetown's fleet is composed of 2 scallopers, 5 line trawlers, 3 gill netters, and 20 otter trawlers and fishes primarily for flounder, cod and scallops. The Provincetown Cooperative Fishing Industries handles most of the catch in processing facilities concentrated on MacMilian Wharf. Provincetown has no capacity to repair or over-haul vessels. Any increase in commercial fishing vessels using the harbor as a home port or landing area would result in competition with recreational craft for mooring and berthing space.

(4) Chatham has a fleet of some 40 line trawlers. Most of the catch is handled through the Chatham 
Seafood Cooperative. Any increase in the fleet in Chatham would aggravate competition with recreational craft for mooring and dock space.

(5) ether ports serve as harbors for smalier fishing craft, as well as single, larger fishing vessels. These ports include Beverly, Ipswich, Manchester, Marblehead, Rockport, Saugus, Cohasset, Scituate, Marshfield, Duxbury, Plymouth, Wellfleet, Hyannis, Menemsha, 'Vineyard Haven and Nantucket. Fishing vessels in these ports must compete with recreational boats for mooring and berthing space, especially during the busy summer boating season. New mooring facilities for the fishing fleet must be built or a mooring allocation system giving preferential treatment to fishermen be instituted if these harbors are to accommodate any substantial increase in the size of the fishing fleet. 
A. Background 53

Fish resources of the sea until recently were considered inexhaustible. During the 1950's many marine biologists suggested that fish protein was the answer to the world's rood problems. As late as 1960 this seemed to be true. Until then the United states and Canada had shared Georges Bank with relatively little competition. But as the foreign fleets in these fishing grounds increased, American fishermen began to be crowded out of their traditional fishing grounds by high technology fishing vessels. In 1972 foreign vessels from sixteen nations accounted for more than $80 \%$ of the catch on Georges Bank.

During this period, foreign catch quotas (outside the U.S. 12-mile territorial zone) were set and monitored by the International Commission for Northwest Atlantic Fisheries (ICNAF). Criticized for weak enforcement, ICNAF began to provide some controls in the last three or four years of its existence. By 1974 all ICNAF signatory nations (the Communist block included) allowed boarding and complete inspection and thereafter began to adhere to annual catch quotas.

In the late 1960's and early 1970's U.S. fishermen appealed to Congress for legislation to help them compete with the highly subsidized fleets of other nations. The "200-Mile Limit Bill" was introduced in Congress in 1973 by Congressman Gerry Studds of Massachusetts and Senator Warren Magnuson of Washington. Three years later the Fishery Conservation and Management Act of 1976 was passed. On March 1, 1977 the 200-Mile Limit, established by this act, gave the United States control of ten percent of the world's fisheries by authorizing a 200-mile "fisheries economic zone" around the U.S. and its territories.

\section{B. Descriotion}

The law authorizes U.S. fishermen to harvest all the fish they need up to an "optimum yield". If there is a portion of the optimum yield which cannot be taken by American fishermen (based on historic catch levels) it wili be allocated to foreign nations with whom we have treaties governing fishing. Permits are granted to countries that have traditionaliy fished in the area, have shown cooperation with the United States, and have contributed to fisheries research.

Overfished stocks such as haddock, cod, and yellow tail flounder are now virtually closed to foreign fleets, but foreign fishermen may continue to catch fish such as dogfish, hake, and squid (which find a market in foreign 
countries but are considered less desirable by American consumers).

Decisions on the size of the annual quotas and what portion of a fishery, if any, will be open to foreign fishermen, are made by the eight Regional Fishery Management Councils. The New England Fishery Management Council has twenty-one members. Seventeen are voting members. of these, eleven are appointed by the secretary of commerce from lists submitted from the five New England coastal states, five are the directors for fisheries of each of the coastal states (or their designees) and one is the Regional Director. In addition there are four non-voting members. They include representatives of the Department of state, the U.S. Coast Guard and the National Marine Fisheries Service. At present there is one vacancy on the council.

Implementation of the plans developed by the New England Regional Fishery Management Council is carried out by the U.S. Secretary of Commerce in cooperation with other federal agencies. She may call upon the secretary of state for assistance in international negotiations, the National Marine Fisheries service (NMFS) for scientific and economic information and the coast Guard to enforce fisheries regulations at sea. The costs of administration are to be offset by fees for the permits issued to foreign nations.

\section{Impact of the 200-Mile Limit}

(1) Immediate impact: Although fishermen and other experts anticipated that the full impact of the 200-mile limit would not be felt for three to five years, there appears to be surprising immediate impact on the domestic fishing industry.

For example, after years of decline the New England fleet's catch for the first part of 1977 was $25 \%$ above last year's levels, according to a Wall street journal article of July 1977. Landings in Boston were high in July, dropping back when the cod fishery was closed in August. Foreigners are pressing domestic fishermen to contract for supplies of American caught fish or to contract to catch portions of the stock allocated for the domestic fleet.

Besides attracting foreign processors, the 200-mile limit is also stimulating investment within the U.S. fishing industry itself. The National Marine Fisheries Service reported that its guaranteed loans for fishing vessels in Massachusetts totaled $\$ 21$ million in the just ended fiscal year compared with $\$ 8$ million in fiscal 1976 and $\$ 5$ million in fiscal 1975 .

The Newport Shipyard of Newport, Rhode Island is completing its first fishing vessel since the 1940 's for 
delivery ${ }_{55}$ to Gloucester and beginning work on additional vessels.

The increase in catch by the domestic fleet and limited foreign catch under the 200-mile limit has caused some problems for processors of fresh and frozen fish. The frozen fish processors have experienced some dislocation of their operations as a result of catch limits placed on the foreign fleets. On the other hand, U.S. fresh fish processors lack the capacity to turn out frozen fish in the volume that the large rood product companies require and thus are unable at present to flll the gap left by the foreign fleets. The inability of the processors to absorb today's rising catch for processing, either as fresh or frozen products, has forced fish prices down. (It should be noted, however, that lower seasonal prices are also common in the summer).

While there was immediate enthusiasm among fishermen about the positive impact of the 200-mile limit, by early summer the Fisheries Management Council cautioned that New England fishing vessels were landing substantially over the projected catch for species such as haddock and cod and that it might be necessary to cut off fishing in these species before the end 6 of the year to conform with the Management Plans' quotas. By september these predictions were proved accurate; the cod fisheries were closed because quotas had been reached. This has caused considerable hardship for fishermen. Compromise regulations have been proposed and are being considered by the U.S. Secretary of Commerce.

\section{(2) Long Range Impact}

While there is general agreement that it will be three to five years before the full impact of the 200-mile limit is felt, no one in the fishing industry or the government and research groups considering the issues knows quite what will happen in the long run.

The most comprehensive assessment of the impact of the 200-mile limit on the New England groundfish industry is a study done for the New England Regional Commission by the Coastal Rescources Center of the University of Rhode Island. The study projects a $40 \%$ increase in employment for the fishing industry for New England and a $30 \%$ increase in employment for the Boston fishing industry. It is assumed that the federal government will provide some financial assistance to the fishing industry and that domestic fishing will take over part of the catch going to foreign vessels.

In addition the Massachusetts Coastal Zone Management staff predicts that New England landings will double over the next five years. This assumes a $25 \%$ reduction of foreign fishing. The doubling will result in a catch of 925 
milion pounds. MCZM states that the 200-mile limit could lead to the creation of 5,000 to 10,000 jobs in Massachusetts alone in the next decade, in marketing, processing and boat construction.

These CZM projections are based in part on a survey of New England fishermen undertaken in 1976 by CZM staff. Fishermen were asked their opinion on the impact of the 200-mile limit and marketing development efforts for underutilized species on the fishing industry. Generally the responses indicated that fishermen were optimistic about the future of the industry. It was agreed that there would be an increase in domestic fish landings. However, it was not agreed by how much these landings would increase. $28 \%$ replied that landings would increase by between $50 \%$ and $100 \%$ and $26 \%$ expected an increase over $100 \%$. A small group ( $12 \%$ ) felt landings would not increase. $34 \%$ believed landings would only increase by by $50 \%$ or less ( $1 . e$. to the levels experienced in the early 1960's). The fishermen did agree that the 200-mile limit would not bring immediate results. $47 \%$ said landings would increase over a four to five year period while $33 \%$ believed results would not show for six years or more.

When asked if fishing boats would be replaced by new ones $53 \%$ replied yes, $47 \%$ replied no. $62 \%$ felt replacement vessels would not be larger than those in the current pleet.

61\% of those questioned indicated that markets for underutilized species will be "sizeable but not as important as traditional species." l9\% felt that underutilized species will be as important as traditionally harvested species. $20 \%$ replied that underutilized species will not be significant at all.

The fishermen also saw improvements in harbor facilities as being crucial to increases in the fleet and future landings. Boston fishermen cited the main barriers to establishing marketing and processing development as i) the need for pler or dock lmprovements 2) the need for sufficient landings to justify construction of processing plants, and 3) the need for demand to justify construction of ice plants. One individual commented that nlocal processors cannot afford to build adequate processing factories because of Boston's high taxes. State, federal (or city) aid must be providedn.

The MCZM study makes several assumptions. First foreign fleets will not be entirely excluded from U.S. fishing grounds under the 200-mile limit. Although they have been excluded from catching most groundfish (the fish harvested by domestic fishermen) they are still permitted to fish in our waters and have been allocated certain tonnages for other species of fish; including mackerel, herring and 
squid.

\section{(3) Impact of the 200-Mile Limit on the Boston Fish Pier}

The facilities on the Boston Fish Pier must be rehabilitated if Boston is to take advantage of the opportunities provided by the 200-mile limit. Massport, as the present owner of the property, plans to undertake this project with the support of the City of Boston using federal funds. The renovation of the Fish Pier will provide modernized facilities for the fish processors presently located there and will encourage the growth of the fresh and frozen fish processing industries in the Boston metropolitan area.

The expansion of the Boston fishing industry is expected to generate many new jobs in fishing, processing and wholesaling. The number of individuals employed as fishermen and crewmen is expected to practically double (from 75 to 138). Employment in fish processing plants and support industries is expected to increase from approximately 1,100 to 1,925 . Several frozen fish processors on Northern Avenue are presently developing expansion plans. The continuation of this trend of increased investment can only mean additional jobs for Boston and renewed prosperity for the fishing industry. 
While the implementation of the 200-mile limit on March 1, 1977 has signalled new potential for the New England fishing industry, particularly for the fishing fleet, many issues remain to be faced. These issues include: the role of foreign fleets and investors, the ability of the government to enforce the 200-mile limit, the ability of the domestic industry to respond to the potential of the 200-mile limit, the need for more active marketing of fresh and frozen fish, the impact of off-shore oil, and the role of the U.S. Government.

\section{A. Bole of Foreign Eleets and Investors}

In response to the limitations of foreign fleets under the 200-mile limit, foreign factory ships are now eager to contract with domestic fishermen. William Gordon, Director of the National Marine Fisheries Service, Northeast Region, reported that in the first four months after the implementation of the 200-mile limit more than thirty delegations from Japan, Poland, West Germany, and Italy visited New England in search of fish. Other foreign companies have begun to explore invesiment in processing plants in New England. One such profit has been constructed in Everett by an Icelandic company.

The National Marine Fisheries Service conducted hearings in August 1977 to determine U.S. government policy regarding joint ventures of this type involving foreign investment. There is considerable divison among the various factions of the fishing industry on this issue. The domestic processors are concerned that if U.S. vessels off-load their catch at sea to foreign processing ships U.S. processors will lose business and jobs. U.S. fishermen, on the other hand, point out that for years U.S. processors have been buying fish from foreign vessels without regard for the domestic fleet. If foreign processors offer higher prices, some fishermen state it is the right of the U.S. fishermen to sell to the highest bidder. The issue is complicated by the fact that, at least in the short run, U.S. Presh flsh processors cannot assure the domestic fleet that they will have the capacity to bandle the volume of fish being caught. At least twice in the first four months of the 200-mile limit New England boats have been turned away because of lack of capacity.

An additional factor in this complex situation is that the present quotas were based on estimated capacity of the domestic fleet. If foreign vessels are permitted to catch portions of the domestic quota not being caught by American fishermen it is feared that over-fishing will once more be the result. 
National Marine Fisheries has promised a formal policy on joint ventures by the fall of 1977 .

Meanwhile, nearly fifty other nations have followed the lead of the United States and Germany and have established 200-mile fishing zones. Japan, West Germany and the soviet Union countries which have had substantial fleets on Georges Bank in recent years, have suffered substantial dislocation of their fishing industries. Fish bices in Japan have risen sharply in the last six months. Up to 5,000 fish processing workers in Germany may lose their jobs; and the Soviet Union has embarked on major diplomatic efforts to secure acfess to fishing grounds off the coasts of Africa and Asia.

\section{B. Ability of U.S. Government to Enforce the} 200-Mile-Limit

The continued presence of foreign fishermen on Georges Bank will inevitably present problems to the management of our fish stocks. The most unavoidable complication is that of by-catch. Whenever a catch is made, fish are unintentionally captured in the net. Thus, cod, haddock, or pollock may be landed even when a foreign trawler fishes for herring. Another problem involves enforcement. All catch regulations have to be enforced by the U.S. Coast Guard. The area which the coast Guard must patrol has been enormously expanded, and administrative and funding problems may delay the institution of adequate enforcement procedures.

The effectiveness of the 200-mile limit depends on governmental policy, the stance that the state Department takes toward its enforcement, and the extent to which subsidization is provided to the fishing industry. Both the State and Defense Departments originally opposed the passage of the 200-mile linit law, arguing that exclusion of foreigners from U.S. waters wight jeopardize carefully developed international relations. So far, cases involving possible violations of the law have been bandled very carefully. Suspect vessels have been allowed to be searched by Coast Guard patrols only with explicit permission from the State Department and if there is concrete proof that the law has been violated. No general policy for enforcement of law has yet been developed.

At present, events in international politics appear to affect decisions on individual cases. For example, the Coast Guard was ordered not to seize the first three soviet vessels it wanted to detail during March because the delicate SALT talks with the soviets were just beginning.

It must be remembered that regulation is being imposed upon U.S. groundfish stocks because of the threat of 


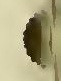


overfishing not only by foreign fishermen, but also by domestic fishermen. Thus, the quotas upon the endangered species are rather stringent, and will continue to be until the Regional Management Council feels the stocks have recovered. For example, after only four months of the 200-mile limit the 5,000 metric ton quota for cod in the Gulf of Maine was reacheq, and the fishery was closed for the balance of the year.

\section{Ability of the Domestic Industry to Respond to 200-Mile Limit potential}

The National Marine Fisheries Service has estimated that if foreign imports were kept constant, domestic catch of groundfish would have to ingryease by $250 \%$ to meet domestic demand for fish by 1985.65 With foreign imports cut back the demands on the domestic fleet will be even greater. This raises a number of significant questions regarding the capacity of the domestic industry to respond.

(1) Vessel Financing: There is nearly universal agreement that if the domestic fleet is to compete effectively, considerable investment must be made in upgrading the New England fleet. Whether or not new vessels are added immediately (and this is an area of uncertainty), it is essential that loans to fishermen, boat owners and processors be readily available at reasonable interest rates. Only an improved fleet will be able to increase the catch substantially and fish at a level competitive with foreign fleets.

(2) Eresh vs. Frozen Fish: In recent years the domestic fleet has focused primarily on catching fish for the fresh fish and frozen fillet market. Foreign fleets have been the primary providers of the frozen blocks which are the raw material of the frozen fish processors. An important issue to be resolved is whether the domestic fleet can respond by catching and landing fish in the form required by the existing domestic processors. A failure on the part of the existing fleet to respond to this issue may force processing firms to invest in fishing vessels designed to catch fish for the frozen block market. This investment would be the type of vertical integration which presently exists in the Canadian fishing industry where the same corporation controls the catch, processing and distribution of fish.

Thus, if the various components of the domestic fishing industry are to fully benefit from the potential of the 200-mile limit the fish processors, boat owners and fishermen must all be willing to adjust to the realities of the modern market and available technology. Available fleet

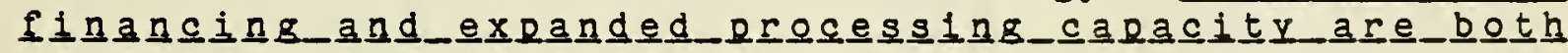
necessary components of a revitalized fishing industry. 
1. Coastal Zone Management of fice, Review of Current Status and Euture Prospects for Massachusetts Commercial Fisheries, Draft 1975 .

2. Mayor's Office of Commerce \& Manpower, Background Materials on the Boston Fishing Industry, December, 1973 , Section 3 .

3. Coastal Resources Center, Graduate School of Oceanography, University of Rhode Island, Fishing and Petroleum Interactions on Georges Bank, prepared for New England Regional Commission, March, 1977, Page 2.

4. King, Maxwell, "Down To the Sea With Money", Forbes Magazine $10 / 15 / 77$.

5. Lieutenant Governor's 200-Mile Work Group, Massachusetts Eishing Industry, Draft Report. May 13, 1977, Page 3 .

6. New England Regional Commission, Op. Cit. Vol 1,.

7. David Boeri and James Gibson, Tell it Good-Bye Riddo: The Decline of the New England Off-shore Fishery, International Marine Publishing Company, Camden, Maine, Page 7 .

8. Alan J. Brown, Op. Cit. Pages 145-148.

9. Lieutenant Governor's 200-Mile Work Group. Op. Cit.

10. King, Maxwell, Op. c1t.

11. 200 Mile Work Group, Op. cit.

12. New England Regional Commission, Op. Cit. Vol. I, Page 3.

13. Mayor's office of Commerce and Manpower, Op. Cit. Section 2.

14. Boeri, David and James Gibson, Op. Cit. Page 38.

15. Wall Street Jeurnal. "Bon Voyage: After Years of Decline, United States Fishing Industry is Beginning to Boom", July 25, 1977. Page l, by Neil Ulman.

16. Boer1, David and James Gibson, Op. Cit. Page 55.

17. Ibid, Pages 79,80 .

18. Mayor's Office of Commerce and Manpower, Op. Cit., Section 1, Labor and Resource Problems.

19. National Marine Fisheries Service, Fishery Market News 


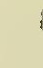


Report statistics. B-94.

20. Boston. Flobe, "Fishermen Grapple with Drop in Prices", Paul Langner, July 1977 .

21. Brown, Alan J., Op. cit., Pages 159-160.

22. Much of the material in this section is based on material from Alan J. Brown's thesis "Future Prospects for New England Domestics Imported Fish Processing and Handing Facilities" Chapter V, Fish Processing and Handing Methods. Pages 193-205.

23. King, Maxwell, op. cit.

24. New England Regional Commission, Op. Cit. Vol. II, Page 153.

25. Correspondence with Hugh O'Rourke, Executive Secretary, Boston, Seafood Council, July 27 , 1977 .

26. Boeri, David and James Gibson, Op. Cit.

27. Greenbaum, Daniel, "Fishing Prospects for Boston", Massachusetts Port Authority, internal memorandum, April 2, 1976 .

28. Mayor's Office of Commerce and Manpower, Op. Cit., Section I.

29. Boeri, David and James Gibson, Op.. Cit. pp 59-60.

30. Quoted by Frederick Bell, The Economics of the New England Eishing Industry, Research Report No. 31 to the Federal Reserve Bank, 1966 .

31. New England Regional Commission, Op. Cit. Page 85 .

32. New England Regional Commission, op. Cit. Summary and Conclusion, pp. vi-x.

33. Much of the material in this section is derived from. Tell it Good-Bye Riddo by David Boeri and James Gibson, Chapter 6.

34. Mayor's Office of Commerce and Manpower, op. cit., Section 4, Historical Highlights of the Fish Pier.

35. King, Maxwel1, Op. Cit.,

36. John Vandruska, "Comparison of Government Assistance for United States and Foreign Fishermen with Special Reference to New England and ICNAF Convention Area", File Manuscript No. 99 , March 1972 .

37. University of Rhode Island Department of Resource Economics, 
"Subsidies to Canadian Groundfish Industry:

Information For Countervailing Duty Assessment". Kingston, Rhode Island, 1977 , Page 8 .

38. Midshipman William T. Rogerson, Jr., "New England Fishermen, Imperiled Species", U.S. Naval Institute Proceedings, December, 1973 , Page 46.

39. William W. Warner, "The Politics of Fish: At Sea with the International Fishing Fleet", Atlant1c Monthly, August 1977 , pp 35,36 .

40. Boeri, David and James Gibson, Op. Cit. Page 24.

41. Ibid, pp 120-122.

42. Harvard Workshop in Community Development Finance, Eishing Boat Production at the Boston Marine Industrial Park- a marketing and financial feasibility study, January 20, 1977, page 35. Interview with Dr. Vaughn Anthony, Woods Hole oceangraphic Research Center, October 15, 1976.

43. Ib1d, Page 34 .

44. Rogers, Jr., Midsh1pman William T., Op. Cit. Page 47.

45. Mayor's Office of Commerce and Manpower, Op. Cit., Section 3, The New England Fishing Industry.

46. Charles $T$. Ma1n, Design Criteria Report for the Fishing Industry on the Boston Fish Pier and Northern Avenue Study for Massachusetts Port Authority, July 28, 1972.

47. Mayor's Office of Commerce and Manpower. Op. Cit. Section 3, "Boston's Fishing Industry".

48. Ibid, Section 3, "Historical Highlights of the Fish Pier".

49. Ibid, Section 3, "The New England Fishing Industry.

50. Mintz Associates, Beston Fish Pier Feasibility study. study prepared for Massachusetts Port Authority, September 15 , 1976 , Page 37 .

51. Correspondence with Bob Dunne, New England Fish Exchange, January 13,1977 .

52. Report of the 200-M1le Fisheries Work Group, Op. Cit., pp. $27-28$.

53. Much of the material in this section is based on "A View of the 200-Mile Limit" by Mary Cerullo, as it appeared in Aquasohere Spring 1977 , pp 12-22. 
54. Warner, William W., on.Cit., Page 41.

55. Wall street Journal, 0p. Cit., Page 15, Col. 4.

56. Ken 0. Botwright, "New England Fishermen Pour Millions into New Boats", Boston Globe, July 1977, Quote by Thomas Harris, Vice Chairmen of Regional Fisheries Management Council.

57. John H. Fenstewald, "Beyond the 200-Mile Limit, The New Englander, Page 23.

58. 200-Mile Fisheries Work Group Report, Op. Cit. Page 26.

59. New England Regional Commission, op. Cit., pp. 133, 135, 139 and Massport Survey, December 1977.

60. Wall Street Journal, Op. Cit., July 25, 1977, Page 1 .

61. Hearing on Joint Ventures, held by NMFS, August $8,1977$.

62. Katheryn Tolbert, "United States 200-Mile Zone Lifts Price of Fish in Japan" The Boston Herald American, June 23, 1977. pase 43 .

63. Wall street Journal, Op. Cit., $7 / 25 / 77$.

64. National Marine Fisheries Newsletter, July 7, 1977. "Cod Fishery in Gulf of Maine Closed", Vol. I.

65. Daniel Greenbaum, "Fishing Prospects for Boston", Op. Cit. 


\section{BIBLIOGRAPHY}

1. Boeri, David and James Gibson, "Iell it Good-Bye, Kiddo":

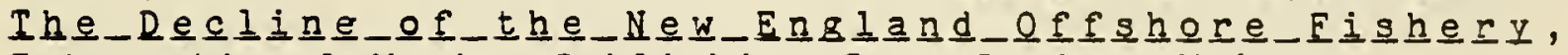
International Marine Publishing Co., Camden, Maine.

2. Bell, Frederick, W., The Economics of the New England Eishing Industry: The Role of Technological change and Government Aid. Research Report No. 31 to the Federal Reserve Bank of Boston, 1966.

3. Brown, Alan J., Euture Prospects for New England and Imported Fish Processing and Handling Facilities, MIT Sea Grant Report 75-7, 1974 .

4. Cerulio, Mary, "A View of the 200-Mile Limit", Aquasohere, Spring, 1977 .

5. Crestin, Dave, paper for use in Joint Ventures Hearings, NMFS, August 8 , 1977 .

6. Devanney, John W., Eishermen and Fish Consumer Income under the 200-Mile Limit. MIT Sea Grant report 75-20, January 15, 1977 .

7. Fenstewald, John H., "Beyond the 200-Mile Limit", The New Englander, January 1977 .

8. Gates, John $M$. and Virgil J. Norton, The Benefits of

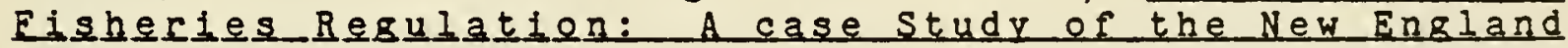
Yellow Iall/Flounder Industry. Sea Grant Resour.ce Economics, University of Rhode Island, 1974.

9. Harris, Inc., Frederick R., Economic Feasibility Study of the Boston Fish Pier for Massport Authority, 1968.

10. Harvard Workshop in Community Development Finance. Fishing Boat Production at the Boston Marine Industrial Park: A Marketing and Financial Feasibility Study, January, 1977. Report for the Massachusetts Land Bank and Boston Economic Development and Industrial Corporation.

11. King, Maxwel1, "Down to the Sea with Money; Forbes Magazine, October 15,1977 .

12. Main, Charles T., Inc. Design Criteria for the Eishing Industry on the Boston Fish Pier and Northern Avenue, study done for Massachusetts Port Authority, July 1972.

13. Massachusetts Office of Coastal Zone Management, Review of Current Status and Fut Commercial Fisheries, Draft, 1975 . 
14. Massachusetts Office of Coastal Zone Management, Coastines, Marc Kaufman, Editor, Boston, Mass.

15. Massachusetts office of State Planning, offshore Qil Development: Implications for Massachusetts communties, prepared under a grant for Office of Coastal zone Management, November 1976.

16. Mayor's Office of Commerce and Manpower, Gerald W. Bush, Director, Background Materials on the Boston Eishing Industry, December, 1973.

17. Mintz Associates, Inc., Economic Feasibility Study of the Boston Fish Pief for Massachusetts Port Authority, 1976.

18. Rathjen, Warren F. and Paul M. Earl, Five Year Plan for

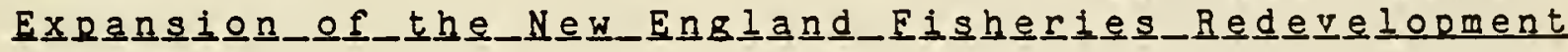
Program, for National Marine Fisheries Service, January, 1977. ETS: 837-9290/Commercial (617) 281-3600 X290, 268.

19. Rogerson, Midshipman William T., New England Fishermen Imperiled Species", U.S. Naval Institute proceedings, December, 1973 .

20. Two Hundred Mile Fisheries Work Group, Massachusetts Fisheries, 1977. (Contact office of Lieutenant Governor Thomas P. O'Neill, for more information.)

21. United States Department of Commerce, A Marine Fisheries Program for the Nation, July 1976.

22. United States Department of Commerce, NOAA, NMFS, Eisheries of the United States, 1976. Current Fishery Statistics No. 7200, April, 1977. (Has a useful list in the back with information on publications, government offices and programs involved in fishing.)

23. United States Department of Commerce, National Marine Eisheries Service, Rolicy for Canada's Commercial fisheries: A summary, May 1976 .

24. United States Department of Commerce, NCAA, NMFS, AtIantic Eisheries: Atlantic Groundfish Plan: Notice of Aporoval. Imolementation and Emergency Regulation, March, 1977.

25. United States Department of Commerce, National Marine Fisheries Service, News releases available from NMFS office at 14 Elm St., Gloucester, Mass. 01930 Tel. (617) 281-3600.

26. United States Department of Commerce, National Marine Fisheries Service, Market News Branch, Eishery Market News Report available 10 Commonwealth Pier, Boston, Mass. 02210 , (617) 542-6070. 


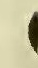


27. University of Rhode Island, Coastal Resources Center, Graduate School of oceanography, Fishing and Petroleum Interactions on Georges Bank, Vols. I \& II prepared for the New England Regional Commission, March, 1976.

28. University of Rhode Island, Department of Resource Economics, Subsidies to canadian Fisheries croundfish Industry: Background Information for countervailing Duty Assessment. Kingston, Rhode Island 02881

29. University of Rhode Island, News and Information Services Christi Dover, News Releases, 22 Davis Hall, for further information call (401) 792-6271.

30. Vondruska, John, "Comparison of Government Assistance for United States and Foreign Fishermen with Special Reference to New England and ICNAF Convention Area" File Manuscript No. 99, March 1972 .

31. Warner William, "The Politics of Fish: At Sea with the International Fishing Fleet", Atlantic Monthly, Autust, 1977 .

32. Wood Hole Oceanographic Institute, Effects on Commercial Eishing.

33. Articles from the Boston Globe, Boston Herald American, and Wall Street Journal. 


\section{EXHIBIT $\quad$ IV -2}

The Boston Fish Pier is situated at a prime inner city waterfront location. While commercial development of the pier would probably be financially more profitable for the Authority than rehabilitation for fish industry users; it would not be as great an impetus for regional employment. Massport's conviction to its public mandate of stimulating commerce and employment and its commitment to the existing port industries, led the Authority to propose rehabilitation of the pier for fish industry expansion.

In the next five to ten years Boston's waterfront will be experiencing considerable development. In the project area: that part of South Boston near the Fort Point Channel (see map IV-2 attachment) several hotels are slated to be built as well as housing in some of the warehouses. The Boston Marine Industrial Park lies immediately south of the fish pier properties. The site for the new Children's Museum and the Transportation Museum is immediately adjacent to Commonwealth Pier. Planning is ongoing for the Seaport Access Road and for rebuilding the bridge over the Fort Point Channel. In summary, the character and condition of this area of Boston will be changing considerably in the near future.

Renovation of the Fish Pier should be undertaken in time to profit by the new interest in fishing generated through the 200-mile limit. 
For example: Just last August a contract was signed between New England Fish Co. (NEFCO) and Mitsubishi Corp of Tokyo for the largest export deal in American fisheries. The agreement, which commits NEFCO to greater efforts in frozen crab, salmon and bottom fish, will result in major exports to Japan and will have a positive impact on the U.S. balance of trade as well as the development of revitalized U.S. fishing and seafood industry. Significantly, the deal occured simultaneously with and is closely related to Congressional Bill 95-354, which clarifies and expands the Fishery Conservation and Management Act. Specifically, the bill restrains foreign fish processing vessels from buving U.S. caught fish before U.S. processors.

As more foreign countries are affected by unilateral fishing zones such as ours and Canada's, demand for U.S. fishing products will rise.

Boston, with its proximity to the Georges Bank fisheries and Logan International Airport is in an excellant position to take advantage of this demand.

Rehabilitation of the Boston Fish Pier will stablize the 1300 existing jobs at the pier, provide $75-100$ short term construction jobs, and create an additional 820 long term jobs in fishing, wholesaling and processing. Using a 2.5 multiplier (such as that used in the ports of Boston, Baltimore and Portland) 2,050 new jobs would be created in New England by indirect impact, for a total of 2870 new long-term jobs. 
Employment opportunities created will be greatest in the unskilled blue-collar labor market and will provide relief to a labor force that has faced steadily decreasing employment opportunities in the City of Boston and in the region. In the last 20 years Boston witnessed a $52 \%$ decrease in blue-collar jobs, from 107,524 in 1946 to 53,236 in 1976 while the number of white collar and professional jobs has remained fairly constant. During the same period, the state of Massachusetts lost $23 \%$ of its blue collar job market while a net gain of $19 \%$ was experienced nationwide. Unemployment statistics clearly reflect the hardships faced by Boston's blue collar labor force. Blue-collar workers faced the highest unemployment rate in the city, an average of $14.5 \%$ as compared to $9.4 \%$ for white collar jobs and $6.1 \%$ for professional workers.

The renovation of the Boston Fish Pier will, by stimulating the growth of the fishing industry in the area, provide currently unemployed low-skilled workers with new jobs and the opportunity to learn new skills.

What might be less clear to those unfamiliar with the industry, is the recent influx of minorities. The fishing industry is highly fragmented. Family business abound and past hiring concentrated among relatives. Recently, however, the industry has been hiring an ethnically diversified group of employees. $76 \%$ of the individuals who joined the Seafood Workers Union during the past 3 to 4 years are members of minority groups (See IV-2 attachments) 
John Nagle and Co. (a pier fish processor) reports that during a temporary expasion 5 years ago, 45 new workers were brought in for short term employment; all of whom were non-white.

To encourage employment of minorities and previously unemployed individuals the Massachusetts Port Authority has hired six CETA workers to perform pier maintenance. When their terms ran out this winter (they started last fall) the Authority hired four of them. The Port Authority recently completed another application to CETA for additional workers. This program will provide unemployed individuals with an opportunity to acquire maintenance and perhaps even fish processing skills. Their work is important not only for Massport but also for any subsequent employer. 


\section{IV-2 ATTACHMENTS}

1. Boston Fish Pier Employment Survey.

2. Letter from L. Nealon, President of the seafood Workers' Union.

3. Massachusetts Port Authority Non Discrimination, Equal Opportunity and Affirmative Action Policy. 
Massport conducted an employment survey in December, 1977 to which 49 wholesalers, retailers, and support industries responded. In January, 1979 another survey was taken on the Fish Pier. Although significant increases $(16 \%)$ in employment were expected in the future, net total of employees did not change. Actual total employment fizures are slightly higher than those reported below, as several small and one medium sized firm did not respond.

\section{On The Pier}

\section{Name of Fir世}

Point Judith Shellfish Co. American Transport Avenue Fish Co., Inc. Blue Sea Fish T. J. Busalacchi Cram SeaEood $D \& F$ Fish Co. Graat Atlantic Fish Corp. Tarbor Looster Corp.

F. E. Harding John Nagle \& Co.

New England Fillet Co., Inc.

No Name Restaurant O'DonnelI-Usen Co.

Puritan Fisin Co.

A. F. Rich Co.

Seaside Fisheries, Inc.

Super Srooty Seafood Corp.

Bart Tribuna Co., Inc. Augustine Daley

New England Fish Ex.

Abramo Fish Co.

$B \& M$ Fish Co.

Boothbay Fisheries

Boston Bonnie Inc.

Boston Conmission Co.

Boston Fuel Injection

Brilliant Seafood, Inc.

John Burns Co.

Fulham \& Maloney

Globe Fish Co.

G. P. Hale Co., Inc.

R. S. Hamilton Co.

JAS. Hook Co.

Jimmy's Harborside Restaurant Klausen-Getsby John Mantia \& Sons

\section{Address}

6 Fish Pier Fish Pier

19 Fish Pier

18 Fish Pier

22 Fish Pier

3 Fish Pier

32 Fish Pie?

41-45 Fish Pier

$151 / 2$ Fish Pie:

16 Fish Pier

33 Fish Pier

Number of Emolovses
39 Fish Pier

15 1/2 Fish Pier

1 Fish Pier

21 Fish Pier

2 Fish Pier

1. Fish Pier

29 Fish Pier

40 Fish Piez

Administration Bldg. Administration Bldg.

Off The Pier

145 Northern Ave.

145 Northern Ave.

280 Northern Ave. Trilling Way

280 Northern Ave.

263 Northern Ave.

253 Northern Ave.

280 Northern Ave.

253 Northern Ave.

145 Northern Ave.

145 Northern Ave.

148 Northern Ave.

15 Northern Ave.

242 Northern Ave.

237 Northern Ave. 236-237 Northern Ave.

\section{6 \\ 4 \\ $\cdot 9$ \\ 18 \\ 6 \\ 17 \\ 45 \\ 7 \\ 32 \\ 34}

15

35

30

16

10

25

16

19

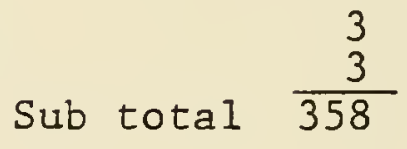


McFisheries

New Hamoshire Fisheries F. J. O'Hara

Paul's Lobster

Pier Fish Co.

Pier Sheet Metal

Sea Frost Fish Co.

Shamrock Fisheries

Stavis Seafood

Turner Fisheries

Westerbeke Fishing Gear

Wharf Forging \& Welding

Yankee Lobster

Total Fish Processors

Fishermen

Massport Employees

Grand Total Employees
255 Northern Ave.

269 Northern Ave.

211 Northern Ave.

150 Northern Ave.

145 Northern Ave.

215 Northern Ave.

145 Northern Ave.

280 Northern Ave.

148 Northern Ave.

1 Fish Pier Rd.

Fish Pier Rd.

20 Ramp Rd.

272 Northern Ave.

Sub-Total
23

19

5

15

11

7

14

15

13

28

4

8

$\frac{14}{655}$

1013

75

15

1103 



\title{
Sea Foad Warkers' Union
}

\author{
Lacal 2 - 9.L.A. - Seried 1572 \\ 9 SOMERSET AYENUE - WINTHROP, MASS. 02152 \\ Telephone: $846.7200,7201$
}

73

February 8, 1979

Mr. John Corrigan, Regional Director

Economic Development Administration

Atlantic Regional Office

600 Arch Street

Philadelphia, PA 19106

Dear Mr. Corrigan:

I am pleased to report that minority membership in the Seafood Workers' Union is growing by leaps and bounds. Minority members in the union presently comprise 27 percent of the total. Over the last four years, 38 percent of new members enrolled have been minorities. In addition, we will be considering the acceptance of an Icelandic firm, which is presently composed of 26 percent minorities in the middle of February 1979.

Sincerely,

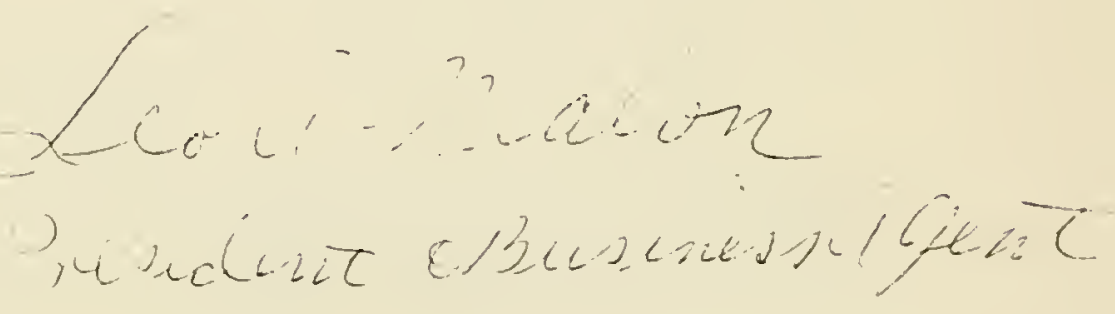





\section{MASSACHUSETTS PORT AUTHORITY \\ NON-DISCRIMINATION, EQUAL OPPORTUNITY AND \\ AFEIRMATIVE ACTION POLICY}

It is the policy of the Massachusetts port Authority to assure through affirmative action that its facilities and economic opportunities are available to all persons without unjust discrimination.

In its personnel practices, the Massachusetts Port Authority shall not discriminate against any person with respect to hiring, discharge, or terms, conditions or privileges of employment on the grounds of race, color, religion, sex, ancestry, national origin or other arbitrary classification. As an integral part of this policy, the Authority affirmatively seeks to improve and increase employment opportunities at all salary levels for groups now underrepresented in its workforce. Numerical goals and timetables for participation by minorities and women in the Authority's employment opportunities are therefore adopted as part of this policy. The Authority is presently developing comparable provisions for attaining and assuring equal employment opportunity for other underrepresented groups.

In addition, the Massachusetts Port Authority takes a special interest in those neighborhoods and 

communities most directly affected by the operation of the Authority's facilities, and seeks to assure the fullest range of employment opportunities for their residents.

All phases of full time, part-time, temporary and seasonal employment are covered by these policies.

The Authority is equally committed to equality of economic opportunity in its relations with its concessionaires, lessees, suppliers, contractors, consultants and all others who benefit through economic relations with the Authority. To the full extent of its legal powers, the Massachusetts Port Authority seeks to conduct all its business with attention to affirmative action goals and to require enforceable equal opportunity undertakings from all those with whom it does business.

In achieving equal opportunity goals and timetables, the Authority also adopts and adheres to non-discrimination affirmative action guidelines and provisions established by the Federal government and the Commonwealth of Massachusetts.

Finally, the Authority's policy also requires the non-discriminatory treatment of all persons with respect to services and facilities provided to the public it serves. The policy of the Authority is therefore to take affirmative action to prohibit discriminatory treatment of any person or organization 

in the services or opportunities offered at all Authority locations.

Every Massachusetts Port Authority employee has a duty to ensure the implementation of this policy. All employees shall receive a copy of this policy. Appropriate summaries of this policy shall appear in Authority publications. The Massachusetts Port Authority stresses that each of its employees is expected as part of his or her job to advance the equal opportunity goals of the Authority.

\section{GOALS, STANDARDS AND TIMETABLES}

A. Equal Employment Opportunity

Because the composition of the Authority's present workforce shows the underrepresentation and underutilization of women and minorities, the Massachusetts Port Authority is establishing goals, standards and timetables in its effort to achieve the speedy elimination and remedy of those patterns.

The Authority's employment policy goals are applicable to the internal affairs of the Massachusetts Port Authority and apply to all terms and conditions of employment at the Authority. These goals are based on the demographic characteristics of the cities of Boston, Chelsea, Revere and winthrop.

1. Minority Employment: The Authority's goal is to achieve $20 \%$ minority representation among the 

employees at every level of the Authority.

2. Female Employment: The Authority's goal is to achieve 40 f female representation among the employees at every level of the Authority.

3. Residents of Areas Particularly Affected by the Authority's operation: Almost $30 \%$ of the Authority's employees are residents of East Boston, South Boston, Chelsea, Charlestown, Revere and winthrop. The Authority does not set a numerical employment target for the residents of these impacted communities, but it is the Authority's goal to increase the availability of Massachusetts Port Authority employment for residents of these neighborhoods at all job and salary levels and to take affirmative steps to upgrade the level of employment that they hold at the Authority.

It is recognized that the pool of applicants for some job classifications is likely to be limited. However, it is the Authority's consistent objective that all job and salary levels reflect the specific goals indicated.

4. Massport Contractors, Concessionaires, Lessees, Suppliers and others With whom It Does Business: To the full extent of its powers the Authority requires of those with whom it does business appropriate affirmative action employment goals 

comparable to its own targets.

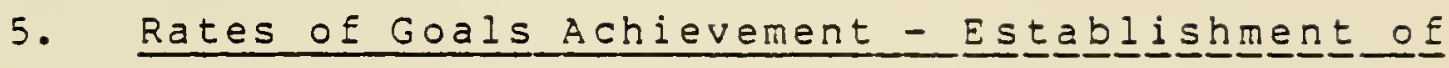
Annual Goals: It is recognized that rates of progress toward achieving equal opportunity goals will be regulated by many interrelated factors such as fluctuating rates of employee turnover which, in turn affect other personnel activities including opportunities for new hires, promotions and transfers. An analysis of each of the Authority's job classifications shall be conducted and will consider anticipated expansion or contraction and turnover of and in the Authority's workforce. This information will form the basis for determining annual goals for hiring, transfering and promoting women and minorities within each unit and/or facility by job classification.

The personnel department, department and division heads, and unit managers will be involved in the annual goal setting process. The Executive Director and the Compliance officer shall review and revise these annual goals as necessary in order to ensure that annual goals are significant, measurable and that they demorstrate deliberate progress toward the employee goals of $40 \%$ female and 208 minority.

Among other factors to be analyzed in establishing annual goals are: the availability of minorities and 

women having the requisite skills; the existence of training institutions capable of training persons in the requisite skills, and the degree of training the Authority is reasonably able to undertake as a means of making all job classes available to minorities and women. After analyzing such factors, if goals for certain units or job classifications are not established or are reduced in scope, the reasons will be detailed. The Authority's goals and timetables shall provide the ability to expand or contract, accelerate or decelerate in relationship to these factors as they influence opportunities to meet goals. It is, however, reasonable to establish as benchmarks that within those job classifications with a $20 \%$ annual turnover rate that minority employment goals can be Eully achieved within 5 years, that more than one half the goals for employing women can be achieved in the same period of time, and the full goal for employing women can be achieved in 8 to 10 years. Semi-annual reports to the Authority's Directors should demonstrate significant and measurable progress toward achieving equal opportunity goals.

The preceding goals apply not only to entry level jobs but also encompass opportunities for employment at every level.

The numerical goals of this Affirmative Action Program are meant to be used as management objectives 

and are not intended to be used to discriminate against employees or applicants who are not of a particular class. The goals, as presented, should not be regarded as maximum quotas; rather the stated goals represent minimum target levels of participation by the groups to which the goal is applied. The goals are not meant to impair lawful rights under existing collective bargaining agreements, but the Authority is committed to promote equal employment opportunity through its own participation in the collective bargaining process.

All Authority employees, presert and future, are expected to carry out their job responsibilities at reasonably established standards of performance and productivity and to comply with the Authority's policies, rules and regulations. The failure of any employee to meet designated job responsibilities will be subject to established disciplinary procedures.

B. Equal Economic opportunity

The Authority has adopted the following goals as its Affirmative Action Program to be brought about through the exercise of its lawful powers in its relations with its concessionaires, lessees, contractors, suppliers and others with whom it does business.

1. Lessees and Concessionaires: The Authority will make substantial affirmative efforts to contact and encourage qualified minority and female 

entrepreneurs to participate in its lease and concession opportunities. In the granting of leases and concessions, or the approval of sub-leases, it is the Authority's goal to achieve not less than $20 \%$ participation in leases and concessions by minority and female entrepreneurs, measured by dollar volume excluding rentals and fees paid by airlines. Determinations of the timetable for meeting this objective will be based on a study of the Authority's non-airline lease and concession dollar volume and the turnover of such leases and concessions.

2. Goods and Services: A substantial proportion of Massachusetts Port Authority contracts and purchase orders for goods and services will be let to qualified minority and female contractors. The goal is not less than 208 of the dollar volume of contracts and purchase orders for goods and services, excluding such items as the public utilities. Affirmative steps will be taken by the Authority to include and encourage minority and female businesses as bidders for the purchase of all goods and services. In order to achieve its affirmative action goals the Authority shall utilize such special modifications to conventional bidding practices as are permitted by law.

3. Construction Contracts: The Massachusetts Port 

Authority will assure, to the full extent of its powers, that every construction contract including maintenance and repair work let by the Authority or by its contractors, lessees or concessionaires, will include provisions meeting or exceeding the requirements of the Supplemental Equal opportunity Anti-Discrimination and Affirmative Action Program as appproved by the Massachusetts Commission Against Discrimination. For its own contracts, the Authority will seek to achieve a goal of not less than a $20 \%$ ratio of minority employee person-hours in each job category. The Authority will make affirmative efforts to increase the bidders lists to include qualified minority and women contractors. As with goods and services, the Authority shall utilize such special modifications to conventional bidding practices as are permitted by law in order to achieve its affirmative action goals.

EQUAL OPPORTUNITY AND COMMUNITY PARTICIPATION

It is an integral part of the Massachusetts port Authority's affirmative action policy to solicit, consider and implement new techniques and procedures for attainment of equal opportunity goals. The Authority encourages members of the communities of which it is a part--including its 

employees and potential employees, and all those with whom it does business or might do business--to bring to the attention of the Authority those ideas, innovations, proposals and suggestions which will assist the Authority and its staff in reaching the goals set forth in this po 1 icy. 

REVISED DRAFT

EQUAL EMPLOYMENT

and

AFFIRMATIVE ACTION PROGRAM

for the

MASSACHUSETTS PORT AUTHORITY

Date of Revision

June, 1978 

Section I

\section{Policy Statement}

$$
\begin{gathered}
\text { Nov, , } 1976 \\
\text { adopted }
\end{gathered}
$$

by Members of the

Massachusetts Port Authority 
This Equal Employment and Affimative Action Program has been eveloped in accordance with the non-discrimination, Equal Opportunity nd Affirmative Action Policy adopted by the members of the Massachusetts Jort Authority and in accordance with applicable federal and state laws ncluding:

M. G. L. Chapter 151 (b); Chapter 149, Sections 1 and Sections 105 (A) to (d): The Governor's Code of Fair Practices - Executive Order 74, as amended and revised by Executive Order 116 ; Admin 21 of DOI code; Bulletin 75-14; Title 29 of USCS; Titl 464 . Title 41, Chapter 60 .

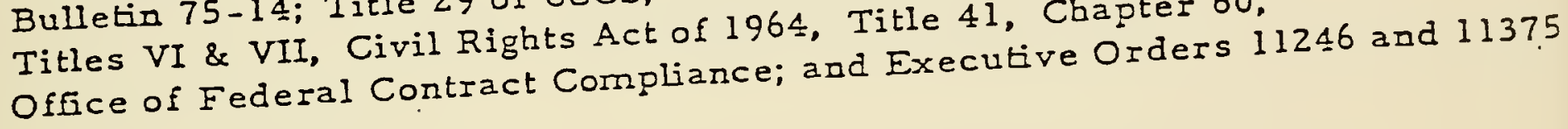




\section{DEEINITIONS}

\section{Racial Groups}

1. White - all persons of Indo-European descent

2. Minorities

a. Black - all persons of African descent as well as those identified as Jamaican, Trinidadian, West Indian and

Cape Verdean.

b. Hispanic - all persons of Mexican, Puerto Rican, Cuban, Dominican or other Latin American heritage.

c. Native American - all persons who are known as such by virtue of their tribal associations.

d. Asian-American - all persons of Japanese, Chinese, Korean, or Filipino descent.

e. Other - all persons of Aleut Eskimo, Malayan, Thais and other nonwhites not specifically noted above. 
It is the policy of the Massachusetts Port Authority to assure through affirmative ion that its facilities and economic opportunities are available to all persons without ust discrimination.

In its personnel practices, the Massachusetts Port Authority shall not discriminate inst any person with respect to hiring, discharge, or terms, conditions or privileges employment on the grounds of race, color, religion, sex, ancestry, national origin or er arbitrary classification. As an integral part of this policy, the Authority affirmative eks to improve and increase employment opportunities at all salary levels for. groups nor rrepresented in its workforce. Numerical goals and timetables for participation by norities and women in the Authority's employment opportunities are, therefore, adopted part of this policy. The Authority is presently developing comparable provisions for taining and assuring equal employment opportunity for other underrepresented groups. In addition, the Massachusetts Port Authority takes a special interest in those :ighborhoods and communities most directly affected by the operation of the Authority's cilities, and seeks to assure the fullest range of employment opportunities for their esidents.

All phases of full time, part-time, temporary and seasonal employment are covert y these policies. 

The Authority is equally committed to equality of economic opportunity in its lations with its concessionaires, lessees, suppliers, contractors, consultants and others who benefit through economic relations with the Authority. To the full extent its legal powers, the Massachusetts Port Authority seeks to conduct all its business ith attention to affirmative action goals and to require enforceable equal opportunity adertakings from all those with whom it does business.

In achieving equal opportunity goals and timetables, the Authority also adopts nd adheres to non-discrimination affirmative action guidelines and provisions establishec if the Federal government and the Commonwealth of Massachusetts.

Finally, the Authority's policy also requires the non-discriminatory treatment if all persons with respect to services and facilities provided to the public it serves. the policy of the Authority is therefore to take affirmative action to prohibit discriminato treatment of any person or organization in the services or opportunities offered at all Authority locations.

Every Massachusetts Port Authority employee has a duty to ensure the implement of this policy. All employees shall receive a copy of this policy. Appropriate summarie of this policy shall appear in Authority publications: The Massachusetts Port Authority stresses that each of its employees is expected as part of his or her job to advance the equal opportunity goals of the Authority. 


\section{Equal Employment Opportunity}

Because the composition of the Authority's present workforce shows the underepresentation and underutilization of women and minorities, the Massacbusetts Port uthority is establishing goals, standards and timetables in its effort to achieve the peedy elimination and remedy of those patterns.

The Authority's employment policy goals are applicable to the internal affairs If the Massachusetts Port Authority and apply to all terms and conditions of employment it the Authority. These goals are based on the demographic characteristics of the cities of Boston, Chelsea, Revere and Winthrop.

1. - Minority Employment: The Authority's goal is to achieve $20 \%$ minority representation among the employees at every level of the Authority.

2. Female Employment: The Authority's goal is to achieve $40 \%$ female representation among the employees at every level of the Authority.

3. - Residents of Areas Particularly Affected by the Autinority's Operation: Almost $30 \%$ of the Authority's employees are residents of East Boston, South Boston, Chelsea, Charlestown, Revere and Winthrop. The Authority does not set a numerical employment target for the residents of these impacted communities, but it is the Authority's goal to increase the availability of Massachusetts Port Authority employment for residents of these neighborhoods at all job and salary levels and to take affirmative ste to upgrade the level of employment that they hold at the Authority. 
It is recognized that the pool of applicants for some job classifications is

likely to be limited. However, it is the Authority's consistent objective that all job and salary levels reflect the specific goals indicated.

4. - Massport Contractors, Concessionaires, Lessees, Suppliers and Others With Whom it Does Business:

To the full extent of its powers the Authority requires of those with whom it does business appropriate affimative action employment goals comparable to its own targets.

5. - Rates of Goals Achievement - Establishment of Annual Goals:

It is recognized that rates of progress toward achieving equal opportunity goals will be regulated by many interrelated factors such as fluctuating rates of employee turnover which, in turn, affect other personnel activities including opportunities for new hires, promotions and transfers. An analysis of each of the Authority's job classifications shall be conducted and will consider anticipated expansion or contraction and turnover of and in the Authority's workforce. This information will form the basis for determining annual goals for hiring, transferring and promoting women and minorities within each unit and/or facility by job classification. The personnel department, department and division heads, and unit manager. 11 be involved in the annual goal setting process. The Executive Director and the ompliance Officer shall review and revise these annual goals as necessary in order to isure that annual goals are significant, measurable and that they demonstrate deliberate Gress toward the employee goals of $40 \%$ female and $20 \%$ minority. 
6) 
Among other factors to be analyzed in establishing annual goals are: the ailability of minorities and women having the requisite skills; the existence of raining institutions capable of training persons in the requisite skills, and the degree if training the Authority is reasonably able to undertake as a means of making all job ilasses available to minorities and women. After analyzing such factors, if goals for :ertain units or job classifications are not established or are reduced in scope, the seasons will be detailed. The Authority's goals and timetables shall provide the ability :o expand or contract, accelerate or decelerate in relationship to these factors as they influence opportunities to meet goals. It is, however, reasonable to establish as benchr that within those job classifications with a $20 \%$ annual turnover rate that minority employment goals can be fully achieved within 5 years, that more than one balf the pals for employing women can be achieved in the same period of time, and the full goal for employing women can be achieved in 8 to 10 years. Semi-annual reports to the Authority's Directors should demonstrate significant and measurable progress toward achieving equal opportunity goals. .

The preceding goals apply not only to entry level jobs but also encompass opportunities for employment at every level.

The numerical goals of this Affirmative Action Program are meant to be used as management objectives and are not intended to be used to discriminate against emplo or applicants who are not of a particular class. The goals, as presented, should not be regarded as maximum quotas; rather the stated goals represent minimum target levels of participation by the groups to which the goal is applied. 
6 
The goals are not meant to impair lawful rights under existing collective Irgaining agreements, but the Authority is committed to promote equal employment opportunity through its own participation in the collective bargaining process.

All Authority employees, present and future, are expected to carry out their job responsibilities at reasonably established standards of performance and productivity and to comply with the Authority's policies, rules and regulations. The failure of any employee to meet designated job responsibilities will be subject to established disciplinary procedures.

B. Equal Economic Opportunity

The Authority has adopted the following goals as its Affirmative Action Program to be brought about through the exercise of its lawful powers in its relations with its concessionaires, lessees, contractors, suppliers and others with whom it does business.

1. - Lessees and Concessionaires: The Authority will make substantial affirmative efforts to contact and encourage qualified minority and female entrepreneurs to participate in its lease and concession opportunities. In the granting of leases and concessions, or the approval of sub-leases, it is the Authority's goal to achieve not less than $20 \%$ participation in leases and concessions by minority and female entrepreneurs, measured by dollar volume excluding rentals and fees paid by airlines. Determinations of the timetable for meeting this objective will be based on a study of the Authority's non-airline lease and concession dollar volume and the turnover of such leases and concessions. 
2. - Goods and Services: A substantial proportion of Massachusetts Port Authority contracts and purchase orders for goods and services will be let to qualified minority and female contractors. The goal is not less than $20 \%$ of the dollar volume of contracts and purchase orders for goods and services, excluding such items as the public utilities. Affirmative steps will be taken by the Authority to include and encourage minority and female businesses as bidders for the purchase of all goods and services. In order to achieve its affirmative action goals the Authority shall utilize such special modifications to conventional bidding practices as are permitted by law.

3. - Construction Contracts: The Massachusetts Port Authority will assure, to the full extent of its powers, that every construction contract including maintenance and repair work let by the Authority or by its contractors, lessees or concessionaires, will include provisions meeting or exceeding the requirements of the Supplemental Equal Opportunity Anti-Discrimination and Affirmative Action Program as approved by the Massachusetts Commiss Against Discrimination. For its own contracts, the Authority will seek to achieve a goal of not less than a $20 \%$ ratio of minority employee person-hour in each job catègory. The Authority will make affirmative efforts to increas the bidders lists to include qualified minority and women contractors. As w goods and services, the Authority shall utilize such special modifications to conventional bidding practices as are permitted by law in order to achieve it affirmative action goals. 


\section{EQUAL OPPORTUNITY AND COMMUNITY PARTICIPATION}

It it an integral part of the Massachusetts Port Authority's affirmative action licy to solicit, consider and implement new techniques and procedures for attainment equal opportunity goals. The Authority encourages members of the communities of ich it is a part - - including its employees and potential employees, and all those th whom it does business or might do business - - to bring to the attention of the thority those ideas, innovations, proposals and suggestions which will assist the athority and its staff in reaching the goals set forth in this policy. 
Section II

Responsibilities. 


\section{Responsibilities}

A Compliance Officer, directly responsible to the Executive Director, has been med and will have the responsibility and authority to implement the Affirmative Action ogram. In order to effectively implement and monitor this program additional staff ay be designated or appointed to assist the Compliance Officer.

The effective implementation of any agency's Affirmative Action Program requires e cooperation and implementation by personnel at all levels of the agency. Thus, at e Massachusetts Port Authority the successful implementation of its affirmative ition policy will require that each department head and supervisor at the Authority bmit and implement an Affimative Action Program designed to bring bis division or prtment into conformity with the overall goals of the Authority. Each supervisor will e required to submit to the Compliance Officer an Anti-Discrimination/Affimative. ction Plan to cover her/his areas of responsibility. Such plan will include goals and imetables designed to have her/his workforce at all levels be $20 \%$ minority and $40 \%$ romen at the end of the stated time period. These long range goals and timetables are tot. inflexible since they cannot be based upon exact predictable statistics such as anticipa urnover, contraction and expansion. Further the "availability" of members of protected :lasses in the labor force may increase if better jobs and opportunities for training and promotion become open to them. Therefore, annual intermediate target goals will be developed for every department and for each under-represented/underutilized group in each job category. The annual minimal goals will be developed for hiring, training, ansferring and promotion. 
Each departnent and unit manager shall participate in assessing factors such as iticipated turnover and training possibilities and use this data to set targets (subject review and revision by the Compliance Officer).

All phases of full-time, part-time, temporary and seasonal employment are covered ithe policy as well as contracting, construction, leases, collective bargaining greements, purchasing and other similar Authority activities. All employees shall eceive a statement of the Authority's Affirmative Action Program and all supervisors/ ivision heads shall receive a copy of this document. Employees who are operationally esponsible for the success of this Program will submit quarterly status reports to the iompliance Officer on the progress or lack of progress of each division in meeting. firmative action goals and objectives. Compliance with this Program will be monitored eriodically by the Compliance Officer as well as on a semi-annual basis by the Executive lirector and Board of Directors and at such other times as may be deemed appropriate. At the same time the Executive Director and the Compliance Officer accept the esponsibility for the development for centralized administrative procedures which will ssist each supervisor in carrying out her/his responsibilities in the area of equal imployment opportunity and affirmative action; it shall, however, be understood that mce the procedures are adopted, the burden for achievement of the Authority's iffirmative action goals rests equally with each supervisor/division head. The achievement of affirmative action goals and objectives by department directors nd unit supervisors will be reviewed as a component of the annual performance review. 
6 
The Compliance Officer of the Massachusetts Port Authority shall have "sign-off" powers over all transactions which affect affirmative action at the Authority. Such sign-off authority (as established in Executive Order 74, as 3mended by Executive Order 116) includes authorization to proceed on all personmel natters, and shall also include review of the execution of leases and contracts, both rendor and construction; collective agreements; and other related matters. No zctivity in which the Authority is engaged which involves the expenditure of money 3. the hiring of personnel will be excluded from this review and authorization. 


\section{Section III}

\section{Massachusetts Port Authority}

Employment: Evaluation of Procedures 


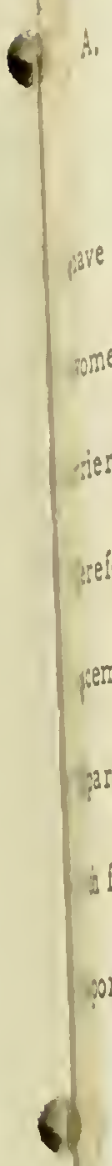




\section{A. Employment}

This section addresses and presents an overview of actions which are planned have already been implemented by the Authority to remove barriers to the employment women and minorities. The identification of internal factors which tend to operate as irriers to achieving long-range and intermediate yearly goals is an on-going process. berefore, all aspects of the employment process, including recruitment, selection and lacement procedures are continually examined by the Compliance Office and Personnel epartment to ensure compliance with the Authority's Affirmative Action Program and ith federal and state statutes and judicial mandates regarding equal employment pportunity.

The current policy on personnel procedures has been reviewed and revised $s$ necessary under the direction of the Compliance Officer and Personnel Director to nsure that all employment policies and practices stated therein are in conformity with ederal and state statutes and judicial mandates regarding equal employment opportunity. Iny provisions (s) of the policy or personnel procedures which are found to be in conflict with the policies or intent contained in this Affirmative Action Program are referred (according to the level of action required) to the Personnel Director, Director of Administration and/or Personnel Committee for appropriate corrective actions.

1. - Job Analysis and Classification Studies

a. - Job Analysis Study - An analysis of all job classes for which perso are employed by the Massachusetts Port Authority has been undertaken. This analysis consisted of reviewing and revising as necessary all current position descriptions to ensure that, for each job classification, the job descriptions accurately reflect the actual tasks to be performed d a ro cnnsistent from one facility to another. 


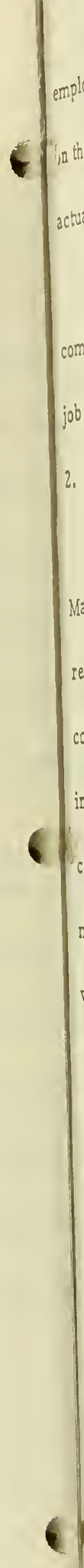


As openings occur, both the description of duties and requirements for employment are re-evaluated for currentness, job relatedness and validity. Based on these descriptions and evaluations, job requirements which are directly related to actual tasks to be performed have been established.

b. - Job Classification Study - The Authority's Personnel Committee reviews completed job descriptions and requirements and makes recommendations regarding job re-classification where deemed advisable.

\section{2. - Recruitment and Outreach}

In order to upgrade the quality of applicants and to assist in the process of making Massport's workforce representative of the population it serves, an aggressive recruitment program directed primarily at the minority and professional female communities has been undertaken by the Authority. The components of this program include: advertising in certain selected publications; an aggressive public relations campaign designed to clearly demonstrate the Authority's commitment to achieve measurable increases of female and minority participation in its workforce; contact with female and minority recruitment organizations and other similar mechanisms,

\section{a. - External Recruitment - A study of recruitment resources, including} executive search firms for members of protected classes and impacted communities has been made and a list of such organizations and media resources was developed and is kept up to date. The Authority's Personnel Department notifies recruitment sources of anticipated and current job openings. Help wanted advertising includes the minority news media, and media of the impacted communities on a regular basis, and states that the Authority is an "Equal Opportunity Affirmative Action Employer, M/F" . 
Any contract or communication that the Authority makes with a recruitment ivurce will be free of implied or explicit preference for a particular race, sex or age roup. All "help wanted" advertisements, posters or other notices will be prepared in in uncomplicated, easy-to-read format. Whenever possible, advertisements sent to Iispanic recruitment sources will be sent in Spanish and English..

Recruitment also includes contacts with other state and city agencies, particularly hose with similar job requirements, to obtain the names and addresses of female and' ninority job applicants. Those qualified applicants, who are identified through these itate and city agencies, will be contacted to determine availability and interest.

Notices of job openings are mailed to the organizations listed in the Appendix; :mployment openings that have qualifications calling for specialized professional or hnical skills and knowledge are also referred to an executive search firm (see tppendix) as well as professional and trade associations.

b. - Internal Recruitment - Bidding - Competitive opportunity must be granted to both internal and external candidates for job openings if affirmative action is to take place at all job and salary levels; therefore, external recruitment activities are timed to coincide with notices of current job openings which are posted at all Massachusetts Port Authority facilities for seven (7) working days. These external activities include, but are not limited to sending notices to female and minority organizations and newspapers as well as using other appropriate recruitment mechanisms. 
- Selection of Employees - The detailed hiring process is presented in Section IV

a. - During the selection procedure applicants will be kept informed regarding the status of their application.

b. - The Authority maintains a retrieval system for minority and women applicants only for the purposes of this Affirmative Action Program. These files are not to be used in any discriminatory manner. Records of applicants from impacted communities are also kept in a similar file. c. - If the applicant is not hired, the personnel officer shall refer back to the protected class or neighborhood retrieval system as future openings occur giving persons in that file first priority on openings in the order of their date of application.

d. - Interview and Evaluation - During the initial stages of the selection process, applicants reached by the foregoing recruitment methods should be evaluated separately from other job seekers. This additional step in the process is intended to facilitate affirmative action and equal employment in the selection process.

- Procedural/Monitoring of Interviews

Reporting forms or other procedures have been developed to identify and analyze barriers to affirmative'action. These key steps will be monitored with records. indicating the effect of each activity by race, national origin and sex: 


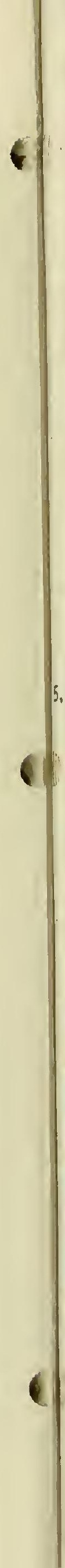


a. - Recruitment sources

b. - Application forms and pre-employment inquiries

c. - Job descriptions (for job-relatedness)

d. - Tests ffor disparate impact; requests average test scores

for each group) (validated for job relatedness)

e. - Interview procedures and results

f. - Physical examination

g. - Reference and security checks

h. - Job assignment

\section{5. - Retaining Protected Class Employees}

Although many of the procedures in this section have been followed on an informa: basis, by March, 1978 the following efforts shall be made standard procedure to encourage the successful and continued employment of protected class members:

a. - The Authority shall emphasize its firm commitment to its Affirmative: Action Program in orientation sessions conducted for all new employe

b. - Follow -up counseling interviews between the Massachusetts Port Authority's Compliance Officer, (or designee) and employees who are members of protected classes shall be conducted periodically in order to determine if any employment adjustment problems have developed and to deal with such problems as they arise:

c. - Starting immediately exit interviews shall be conducted under the direction of the Compliance Officer with all terminating and dismisse: protected class members to explore reasons for leaving or dismissal and to make recommendations to management to correct and/or reme 


\section{B. Placement}

Placement includes: transfer, promotion, training, demotion, lay-offs, recall and termination.

\section{1. - Transfer and Promotion}

In addition to setting yearly targets for the hiring of protected class members, each department unit of the Authority shall set targets for upgrading members of protected classes. These intermediate goals are particularly important in achieving the long-range objective of equal employment in all job classifications.

a. - Remedial Action File - The Authority will establish a "remedial action file", of its present minority and female employees who wish to be included in such a file and who may be eligible for promotion to one or more positions within the Authority.

The "remedial action file" will be established by September 1, 1978. During the compilation of this file, the Personnel Officer will interview and review the records of ch minority and/or female employee who wishes to be included and to:

1. - Update records on the individual's qualification, education, experience, seniority and performance on the job.

2. - Identify individuals who appear to be working in jobs that are below their abilities.

3. - Provide each individual with an assessment of his or her opportunities for advancement, the pre-requisites for such advancement and an estimate of the probability for such advancement becoming a reality. 
The Authority will consult the "remedial action file" when it plans to fill a vacant sition, particularly when the vacancy occurs in a classification where minority persons women are under-represented.

- Training and Education

The Authority recognizes that its Affirmative Action Program must contain a aining component to provide skills that are essential to jobs where women and minorities -e under-represented and to compensate for deficiencies in experience and/or education at resulted from past discrimination.

The Authority will, therefore, make full use of the various training programs railable to it to help meet its objectives for hiring and promoting minority persons and omen. Where no training program exists for the varied job classes, the Authority will :ek to promote and develop such programs in -house or in cooperation with other state, deral or local agencies and organizations.

Because many of the positions (other than entry level) at Logan Airport require a ass II drivers license, a pilot training program in trucking and plow operation was itiated in 1977 and will be expanded in the Spring of 1978. Upon successful completion : this program an officer of the Registry of Motor Vehicles tests our employee-candidate If the class II license.

During 1977, the Authority also participated in Northeastern University's Women's areer Project (WCP), a program designed to provide job specific courses and supportive unseling to prepare course participants middle-level management positions which had been Irgeted by the Authority. 
Two positions were targeted and committed to the WCP: one for an internal andidate in the Accounting Department and one for an external candidate to be laced in the Community Affairs Department. The internal candidate assumed her ew responsibilities in August, 1977. Representatives from the Peisonnel and ompliance Departments will be meeting with the WCP in February of 1978 .to iscuss future participation by the Authority in the Program.

In 1977, the Authority also participated in the YWCA's Non-Traditional iccupations for Women and committed five (5) summer job slots to program raduates in the Building and Field Maintenance Departments. In 1978, we fipate a continuation of our participation in this program.

From January to June 1978, the Authority will be implementing a two year nanagement training program which will involve 5 to 8 positions which will provide :xposure for candidates selected to at least four different operating and administrative lepartments. The Authority's Human Resources Manager holds primary responsibility or the design and implementation of this project and will work closely with the Complianc Jffice in selecting trainees.

Other plans include meetings with the Boston OIC to explore the possibilities of joint training program with that organization.

a. - Internal Training - The Authority will ensure that all initial training and job familiarization procedures for each department are provided in a non-discriminatory manner. Where it is indicated that this initial on-thejob training and orientation results in a high turnover rate among protected classes then new methods and procedures shall be developed. 

b. - External Training and Education Programs - In addition to making full use of the outside training programs available to it, the Authority shall ensure that any skills, training or educational program to which the Authority provides resources (financial, materials, or personnel) is in compliance with the Authority's Affirmative Action Program. Authority employees, particularly women and minority group members, shall be made aware of educational opportunities and the Authority's policies on education benefits and leaves.

c. - Training - Affirmative Action Program - Training for management and supervisory staff shall acquaint them with the Authority's Affirmative Action Program. This training will include techniques designed to increase the sensitivity and awareness of the Authority's management and supervisory staff to the issues inherent in the implementation of an Equal Employment/ Affirmative Action Program and shall provide the basis for its practical application in "on-the-job" situations. It is anticipated that this sensitivity training will be provided by an outside consultant/trainer. The cost for this will be included in the Compliance Office budget which will be presented to the Board of Directors in June, 1978. If approved and after a consultant/ trainer has been identified and selected, it is expected that the training will begin by October, 1978. Such training will also include an explanation of: 
1. - All provisions of the Authority's Affirmative Action Program.

2. - The legal basis of an Affirmative Action Program.

3. - Supervisory responsibilities related to affirmative action.

4. - The legal options available to a person making a complaint of alleged discrimination.

A training program for all the Massachusetts Port Authority employees has been ;tablished to explain the purpose of the Affirmative Action Program to stress the uthority's commitment to this program, to answer any questions that employees may ive regarding the program's intent and to explain individual employee affirmative ction responsibilities and benefits.

All Authority employees at Logan Airport received this training in sessions I between April to July, 1977. Sessions for employees at Hanscom Field, the obin Bridge and Port division are planned for the same period during 1978.

In order to encourage employees to increase their knowledge and skills and hereby gain eligibility for possible promotional opportunities, the Compliance Officer I designee shall counsel employees upon request regarding educational and training pportunities available in the community. A special effort shall be made to encourage nembers of protected classes and impacted community residents to participate in urther education and training programs. 


\section{Affirmative Action Grievance Procedure}

A grievance procedure shall be developed by . April, 1978 under the direction of e Executive Director and Compliance Officer and will be reviewed by the Anthority's ersonnel Committee. The purpose of this procedure is to provide an orderly, timely ad equitable means of investigating and resolving internally and informally, rubenever racticable, complaints relating to alleged discriminatory policies or practices. The rocedure shall not cover any other matters and shall be the exclusive internal rocedures available to Massachusetts Port Authority employees, tenants, concessionaire ad to the general public for resolving complaints regarding alleged discrimination.

Such procedures shall in no way be designed to supersede or replace existing emedies available to employees, tenants, concessionaires or the general public under

il rights statutes or collective bargaining agreements.

- - Collective Bargaining Agreements

Every agreement between the Authority and its collective bargaining units has een examined for policies or procedures which may result in equal employment/ firmative action barriers. Between January 1976 and December 1977, all agreements ave come before the Authority for re-negotiation. The Compliance Office has provided ew and/or revised clauses to the Authority's negotiating team for inclusion in the new greements. Every agreement now includes an affirmative action/equal employment lause covering all procedures of the agreement. Contracts with collective bargaining nits shall be continually reviewed and revised wherever current provisions are

Atified as barriers to equal employment. 


\section{- Other Terms and Conditions of Employment}

(1) There shall be no unlawful discriminatory practices by the Massachusetts Port Authority with regard to any terms and conditions of employment including ut not limited to those which have been heretofore discussed. 
-

Section IV

Hiring Process

As Reviewed and Approved

By The Authority's Personnel Committee 


\section{Hiring Process}

\section{Massachusetts Port Authority}

cojected Goals

Hiring Process

- Job Vacancies - Openings

I. - Job Descriptions
Each Division/Department/Unit Manager will project annual affirmative action hiring goals for each job category when developing their overall hiring projections for the year. The affirmative action hiring goals will be reviewed and revised as necessary by $t$ Compliance Director to assure conformity with the Authority's affirmative action goals and timetables.

\section{Responsibilities/Procedures}

Whenever a vacancy occurs or a new position is crea it must be reported directly to the Personnel Depart The Personnel Department will notify the Compliance Office with information concerning: whether or not $t$ job (s) will be filled and when; the estimated potentic for neighborhood preference and affirmative action giving consideration to current levels of underrepresentation or under-utilization in the urit; obligations under collective bargaining agreenents; and availability of affirmative action and neighborhor candidates for the position ( $s$ ).

Job descriptions for new positions or those not previously described should be prepared by the appropriate unit supervisors with the assistance of the Personnel Department. In preparing the description, the Director of Administration and/or the Personnel Director may involve other department managers outside of the proposed positions' direct reporting relationship if the job functions of that position cross departmental lines of authority. The: descriptions of duties and requirements for employment will be evaluated for currentmess, job relatedness and validity. 
Job Descriptions

- Job Requisitions

Requirements should be directly related to actual tasks to be performed. The Compli will review descriptions for validity be The Personnel Committee will review descriptions of all new job titles and all position. descriptions with starting sala ries over $\$ 12,000$. Board Members.

in addition to the approval required of the Executive Director or Secretary/Treasurer, the Compliance Office initials and records the job opporturity.

Internal and external recruitnent activities will be timed so that all interested candidates are lonown to the Authority before the selection process bas begun. Internal efforts consist of bid postings at Authority facilities.

External recruitnent will involve advertising in selec newspapers and other publications which are widely read by members of the female and minority communities and residents of commuaities affected by the Authority's operations. Radio and television media forms will be utilized when appropriate for advertising job openings.

Recruitment efforts to fill job openings which have responsibilities that may impact on those cornmunitie affected by the Authority's operations, should include active measures to draw on the resources of those communities to identify candidates.

Job notices will be sent to recruitnent sources such minority and fernale commurity and profes sional organizations, in accordance with existing policy. Search firms will be utilized as needed for diffcult t Ell positions. . Recruitment will also inciude contact with other state and city agencies, particulariy those with similar job requirements. Active recruitenent programs will be carried out at secondary schools, junior colleges and colleges. The current pool of applications and resumes will also be used. 
- Initial Screening

I. - Selection Interviews

II. - Job Award Recommended
Bids, applications and resumes including those already on file will be evaluated. Qualified and qualifiable applicants may be interviewed by Personnel, Reasons for disqualifications will be specified when necessary. Candidates successfully passing through initial screening will participate in the interview process for final selection. The bid: applications and resumes of those screened out will be reviewed by the Compliance Department. All candidates will be informed about the steps in the Authority's selection process.

These interviews will be conducted by unit supervisors/managers with the job opening and/or th Personnel Department. The top 5 candidates will be identified and assessments toward final reconmenda will be made. The unit, Personnel and Compliarice Departments will participate in the assessment in order to make a recommendation for award which ha: included affirmative action and neighborbood preference considerations. Training sessions will be developed for all Authority interviewers concernir areas of sentivity in regard to equal employment opportunities and affirmative action. .

A compliance review form listing all candidates, also naming the successful candidate (s), is prepared by the Personnel Department and all candidates are notified concerning the outcome of the process. Payroll changes and/or additions to the payroll forms are authorized by Persomnel and are signed off by the Compliance Department.

For professional and administrative positions, the resumes of the top 5 candidates (ranked in order of choice, if possible) will be provided to the Personne Cornmittee as part of the back-up material. 


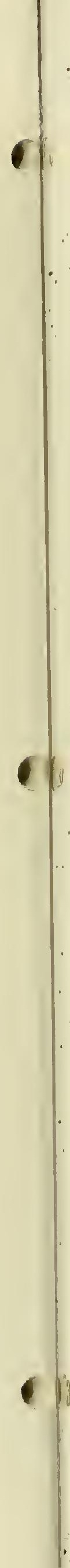




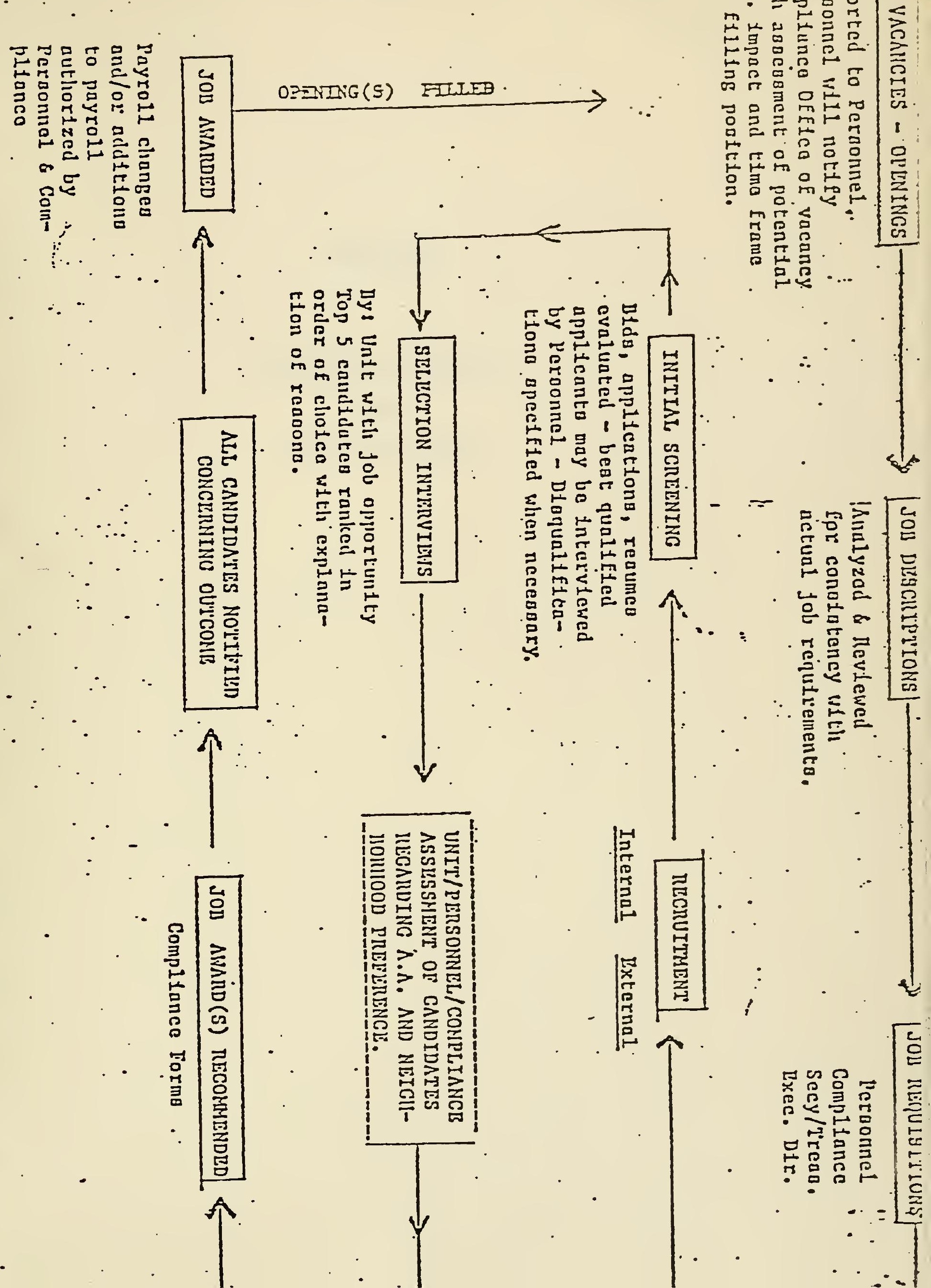




\section{Section V}

\section{Utilization Analysis}

and

Employment Goals 
* City of Boston Population Figures

by sex and minority status

White Males

Minority Males

Minority Fernales

White Females

\begin{tabular}{c}
$\frac{\#}{\#}$ \\
212,587 \\
63,788 \\
77,133 \\
253,909 \\
\hline 607,417
\end{tabular}

\begin{tabular}{l}
$\%$ \\
\hline 3.5 .0 \\
10.5 \\
12.7 \\
41.8 \\
\hline
\end{tabular}

100.0

* Source: Manpower Information for Affirmative Action Programs, Division of Employment Security, U.S. Department of Labor, 1977. See'(appendix). 
1 
Table 2

Massachusetts Port Authority

Employee "Count as of Jan. 1978

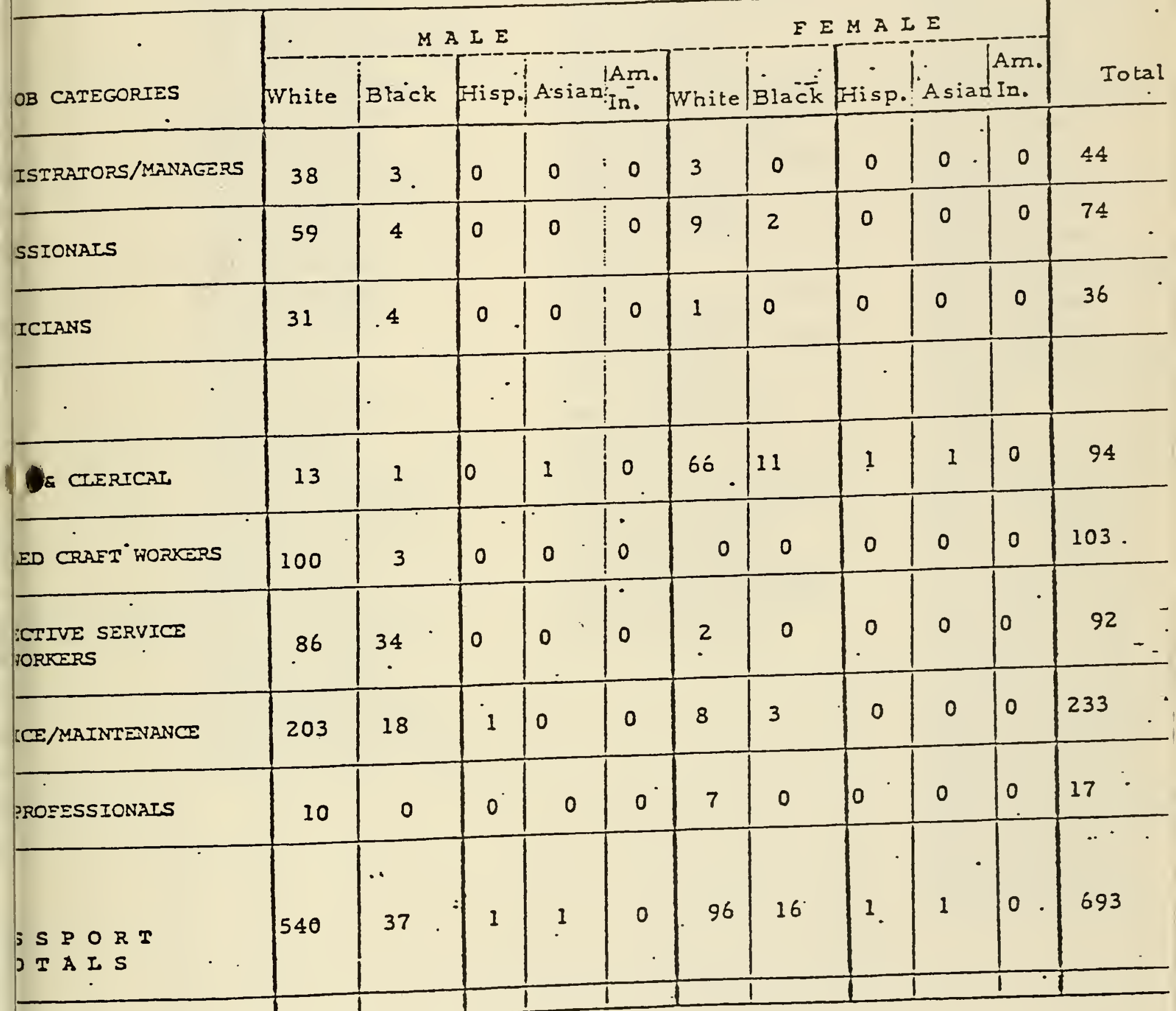


Super. Elec. Dept.

Director of Puschasing

Asat. Comptrolles

Airfort Nanager

Asst. Airport Marager

Build. Maint. Macaget

Haescom Masager

Cbief, Fire Dept

Asst. Chiel Fire Dept.

Parjeng Manager

Oporations Mazager

Asst Field Mainto Masager

Asse Build. Maint. Mazazer

Asst to Port Dir.

Cez. Supt. Ierminals.

- Nust P.R. Directar

- Mgr. Logaz P.R.

Execative Director

See. Ireas/Diz. Adr.

Cortaiser Term. Super.

Placriag Directo:

E=gi=eering Director

32yeketing Director

Dir. of Develo praent

Personnel Director

Compliznce OfEcer

Comptroller

Port Director

Tobin Bricge Director

Aviation Director

Chief Engineer

Deputy Caief $E=g$.

Dir. of Comrs. Alfairs

Asst. to Dir. of C.A.

Mgr. Special Prograras

Ges. Supt. C.I

OEfee Manzger

DI-. of Labor Relations

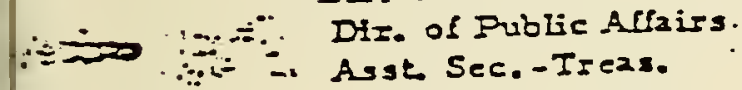

Noise Mgrat. Officer

Port Adrinistrator

Dif. of Budget \& Ficance

Deputy Comptoolles

Manager, Seaport sales
- Toll orgeers

Toll Captais

Toll Lieutenant

Toll Sge.

Skilled Laborer/Bridge

" "L Logza

" "Hancorn

Bldg. Maint. Man A

Power Plast Apprentice

Janitor/Iogan

" Hanscors.

Work Fore./Logan-FM

SI. Mzint Forernan (BM)

Ger. Mairt. Fore. F. M

Garage Mastes - F.M

GIU Supervisor

GIU Dispatche:

Park. Supervisors

Cashiers

Atteridants

Gen. Maint. Fore-Hanscom

Fish Fier Maint.

Fisb Pier Wharf \& Weigh

Foreman-Piers

Maint. Fore.-C.I

Iour Guides-Iogan

Super. -Interpreter

Fl2 graan

Sidlled Iab.P. t. Hanscom

Sazre-a-cab Dispatcher

Foreman, Sign Soop

GTU Service MgT.

Pablic Services Super.

Chiel Pub. Services Rep.

Asst Super. Interpreters

Sazze-z-cab Super.
Bldg. Mairt. Work Foremen

Bldg. Maint. Fore-Bridge

ML. Equip. Bep.
Roofer/Sprzy Paiater

Carp.-Locksmith $A$

$$
11
$$

Carpenter

Felder

C2sp.-Meter Repair.

Plarber

Bldg. Equip. Mechzaic

Masoa A

Mason B

Heatiog Plant Super.

Ist Class Eig.

2ad Cl2ss Eng.

Stear III Ean/IOgan

HVAC Fozemaa

HVAC Mecbaric

HVAC Irainee

Meter/Reader

Fore./5iga Soop

Sin Painter

Fore. Iogax

ME. Equip. Rep. Iogas

Mt. Equip. Rep.

Help. - Iogan

Heary Eguip. Op. - Loga

Mt. Egoip. Repai=20

Bridge

ME. Equip. Bep. Help. Bridge

Hezvy Equip. Op/Bri2g

Elec Forellogar

Elec. Fore./Bridge .

Electician-Iogzan

" Mosan

Elec. THelp.-Brizge

Eexry Equip. Op. Hz=car

Bldg. Equip. Mech-.

Frasscorn

Iermical Operzors

Firecan Mech. -R.P.

Fircead/Fisb Pies

Asechanic/Fish Pier

Eng. 2ad CL-E.P.

Eng. 3 त. C1. -R. P.

Nigit Equip. Op-Ioga

Palater-Loger

Super. -Stat Eng.

3rd Cl Eng.-Iogad

Steaco PipeEuer 
Adninistative Asat.

Stat Clerk-Moras

Billing Clezk-C.I.

Cle=k/Utility Flsh Pier

Pier Clerk/Moran

Plerk Clerk/Corm. Pies

Pler Clerk/E. B. Fier

Adrilnis. Aid/Moran

Telephone Operator

Mail Clerk

Receptionist

Clezk/ Typlat

Executive Seczetary

Secretary

Dat Aralyst/Bridge

Audit Clerk/Rer.

Payroll Clerk

Bookke eper

Acet Payroll Clerk

Flle Clerk

P.R. Clerk

Rer. Clerk

Inveztory Contol Clerk

Acç. Clerk

Copy Clerk

Exployracnt Aide
Chlef Audis

Const. Fuad Acct.

Rev. Control Super.

Parchasiog Agcat

$M_{\mathrm{B}}=$. Rev. ILId-Ácet.

Acct Pay. Maniger

Stall Acct.

Auditor

Cbief, Res. \& Aarlysis

Stalf Asst.

Mgr. Aviation Mrt.

Rochester Rep.

Star Asst. Airport Mg=.

Salety Co-ordi-ator

Insurace Mg:.

Noise Abate. Monitoring Supez.

Comanuity Ale. Liaison

Coman. ACf. R.E. Sup.

Carra. Afr. Fld. Rep.

. Masitine Asst.

Constuction Specialist

Field Inspector

Planging Asst.

Port Asst.

Personael Asst.

Attoraey

Chief Legzl Coarsel

Associate Counsel

Solicitors

Promotion Director

Pier Supervisor/Castle Island

Supt Maint/Morar

Supt. / Castle Island

Op. Supt Moran

Super. Rey. Contol/Castle Island

$C$ \& D Supt./Mlorad

Rev. Control Ageat

Project Eng.

Aipo:t Eng.

Port Eng.

UtiTity Eng.

European Irade Rep.

Wasbington Irade Rep.

Mgr.. N. I. OẼce

Iraffic Solidtor

Equal Opporterity Prechasing Specizlist

Publication \& Research Supervisas

Hسman Resource Manager

Ifbrarian

Merketing Stal Assistart

Systems Plaming Aazlysk

Asst Dir., Cormanity Altirs

Air Cargo Marketiag Rep.

- Beneflts b Corpensation Adrinis.

Caiel. Iechrical SeIflees

Culel, Eavisomental Mgant.

Groand Tran. Plamer

General Acet.

Complian ce Analyst

Mgrat- Pajebrsing Project Mgr.

Mgr. Badget \& Flazace Planaiag

Cxpital Finance Plzanex

Information Speciallist 
rations Asst.

al Asist.

\section{irch Asst.}

Wanager/Acct. Fayroll roll Supervisor

t. Payroll Supervisor

t. Super. Rev. Ciontrol lacial Analyst 's Clk. Analyst/Noise MEnt. rations Super:.

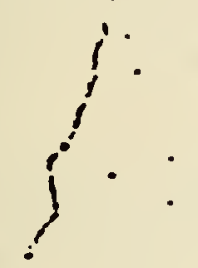

Guard's - Pier \& Gate Guard Forernan - Pier. Asst. Fire Controlman Station Captain Boatman

Crast Crewrian
SI. Designer

Civil Draftsmaz

Draftsman

Mat. Lab. Supervi

Sr. Tncinician

Techrician A

Chief, Survey Dept

Chiel of Party

Instument MaO

Rodrnan

Elec. Tecbrician

Bldg. Cont Super. 
(1) $s$

(i)

() 
With the exception of the Office, Clerical and Technician categories, protected Isses were under-represented in all EEOC designated classifications. As of Tanuary, 1978, minority females and white females were either equitably represented ir over-represented in the office \& clerical category; In the category of technician, ninority males were proportionately represented. (See Tables 1 \& 2).

Further examination of Table 2 also reveals that the Authority's workforce :omposition is most seriously deficient in employing minority females and persons of Hispanic heritage. Minority women are represented in only 3 of the 8 EEOC :ategories, and Spanish-Americans represent only. $3 \%$ of the Massport workforce 11though $3.6 \%$ of the Boston population is Spanish American.

Although it was stated in an earlier paragraph that women and minorities are inder-represented in almost all EEO categories, some of these categories require dditional comment particularly as the current category profile influences the setting if interim goals.

Jficials \& Administrators \& Professionals

Women and minorities are under-represented in these two categories.

\section{Technicians}

Women are under-represented in this category: $2.8 \%$ in the Authority's workforce vs. $5.5 \%$ of population in the City of Boston. Boston SMSA statistics show that $13.7 \%$ of Technicians (except health) are female.

\section{Proteciive Service Workers}

Wenten and minorities are under-represented in this category. The current profile shows $2.2 \%$ of this category to be women and $4.3 \%$ minority. Goals have been established for both groups. Experience at Massport over the past two years shows that if the barriers are removed, increasing numbers of women are willing to accept positions in this classification. Boston SMSA statistics show that the current availability of females for this category is $6 \%$. 
Minority females and minority males are not represented in this category; arefore, goals for fiscal year 179 reflect remedial action to correct these deficiencies.

jkilled Crafts

Women are not represented at all in this category while minority males are underepresented (2.9\%). The workforce participation rate of females in this category for the 3oston SMSA is 5\%. The disparity between minority male representation in the Massport vorkforce and the population statistics for the City of Boston can be attributed to two actors:

1. - relatively low turnover rates which limit opportunities for new hires

2. - the bidding/seniority provisions in collective bargaining agreements.

\section{jervice/Maintenance}

Women and minorities are under-represented. Of particular concern is the legree of under-utilization of minorities and women at the higher paid positions in his category. Although this category has one of the highest attrition rates this urnover occurs primarily at the entry level positions. As with the skilled crafts, emale and minority under-representation and under-utilization can be attributed to:

1. - low turnover at higher paid positions, and

2. - bidding/seniority provisions in collective bargaining agreements 
In accordance with the Board Vote of November, 1976, Table 3 represents e Authority's annual interim employment goals for fiscal year 1979. These interim als are designated to correct short-term deficiences in addition to meeting the longin goals of $40 \%$ female by the end of 1984 and $20 \%$ minority by the end of 1981 . These oals apply to all personnel transactions including transfers and promotions:

While it is not specifi cally represented in Table 3 the Authority's workforce rofile for 1979 should reflect an increased representation of Spanish-Americans.

The January 1979 workforce profile projects increases among affirmative action roups in the following magnitudes:

Current Profile

Jan. 1978

Thite females inority females linority males
Projected Profile

1979

14. $7 \%$

$5.8 \%$

$8.7 \%$
Net of

Increase

$.8 \%$

$3.2 \%$

$3.1 \%$

S.:ice women have been traditionally over-represented in clerical positions thereby reati:ig an inflated profile of the extent of their participation in the workforce, the following ible excludes the category of office and clerical from the calculations:

\section{Excluding Office \& Clerical}

if

Current Profile

Jan. 1978

White females

finority females

Linority males
Projected Profile

1979

$7.0 \%$

$3.8 \%$

$9.3 \%$
Net of

Increase

$2.0 \%$

$3.0 \%$

$3.1 \%$

A comparison of the two preceding tables demonstrates the rationale used in establishir he Authority's goals for FY 79. Increased emphasis has been placed on employing women ind specifically minority women in non-traditional occupations.

As part of the Massachusetts Port Authority's budget process each division, lepartment and unit is setting employment goals including proposed new additions to ; taff. This budget process began in Feb. 1978 and will be completed in June, 1978. 11though this process will not be completed in time for incorporation into this plan, as lepartmental goals are submitted they will be reviewed and revised by the Compliance Jffice in accordance with the overall objectives expressed in this plan.

The goals established here are to be operative until the Authority's members adopt lew interim goals for fiscal year 1980. 


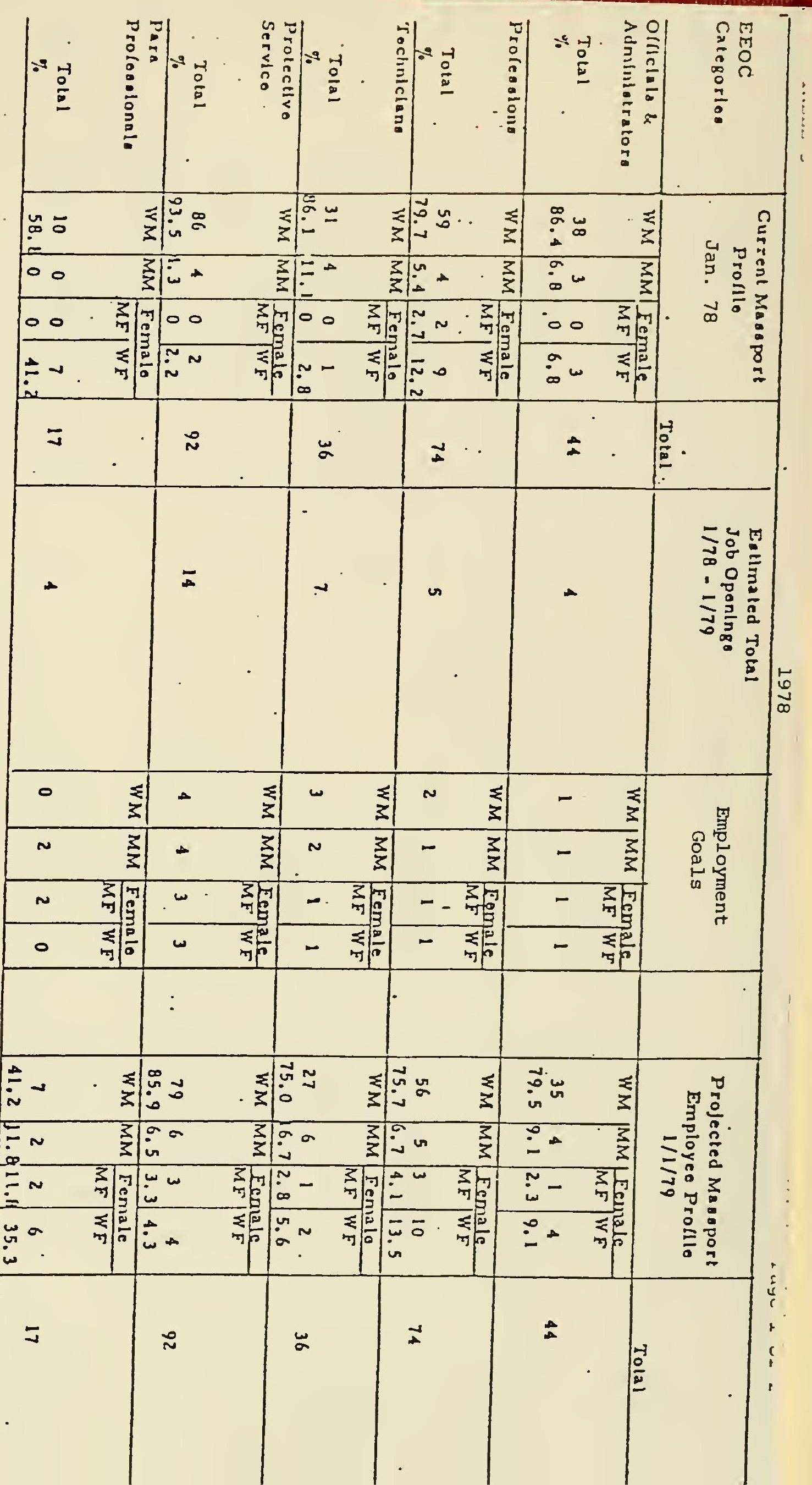




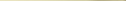




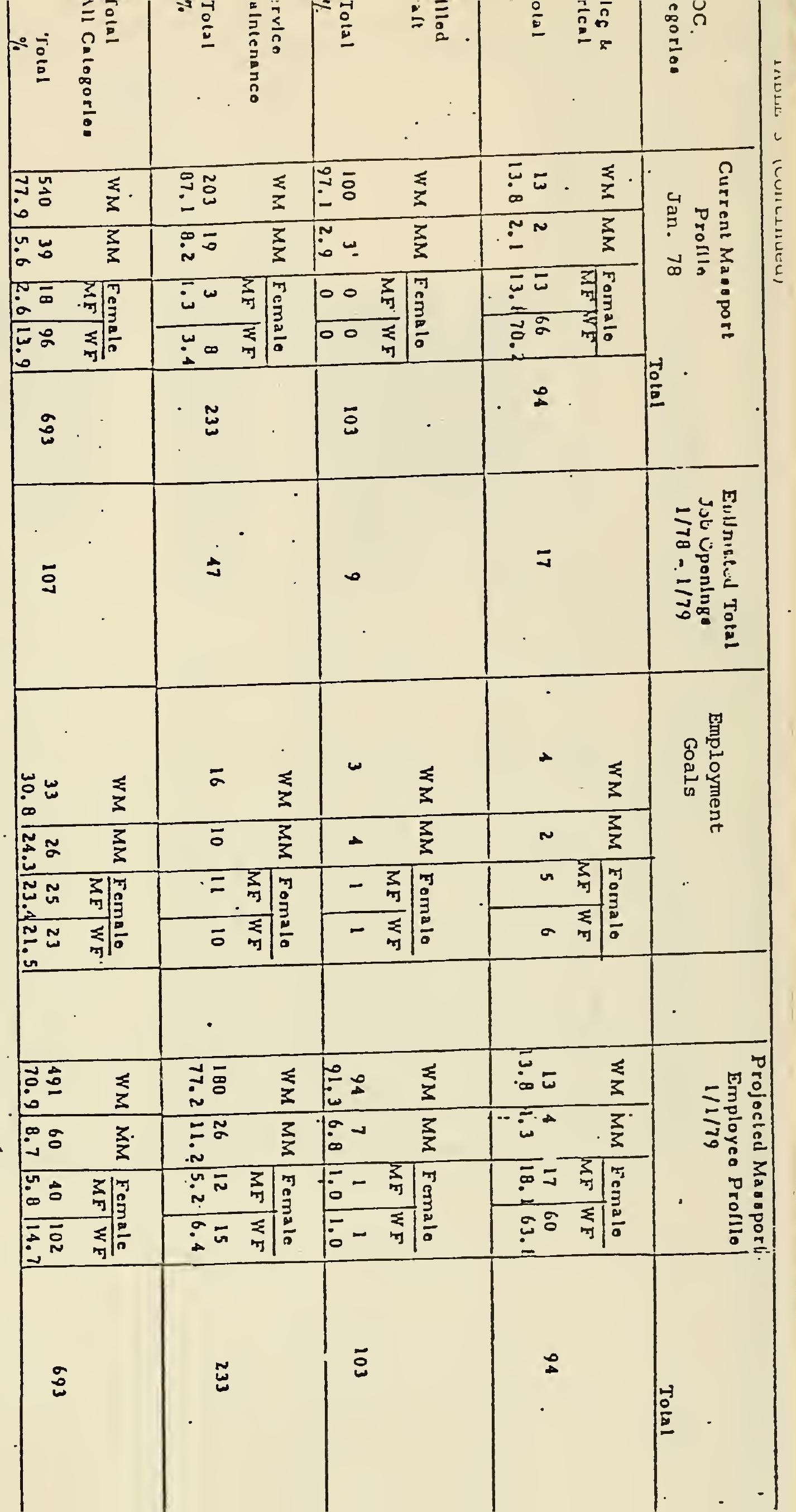


in

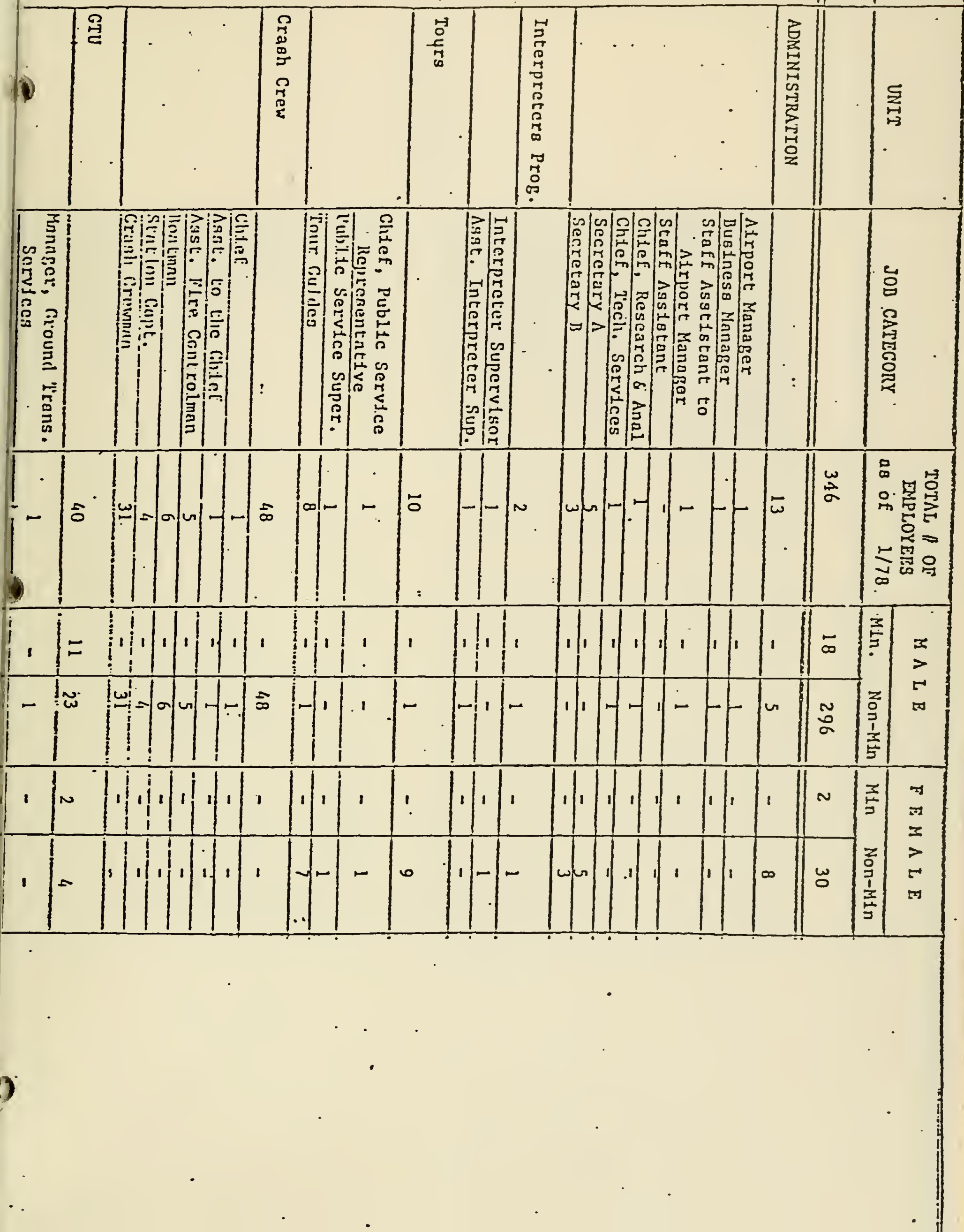


. 


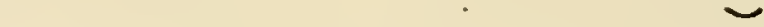

भ्रे

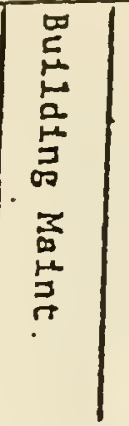

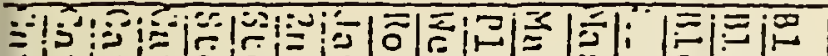

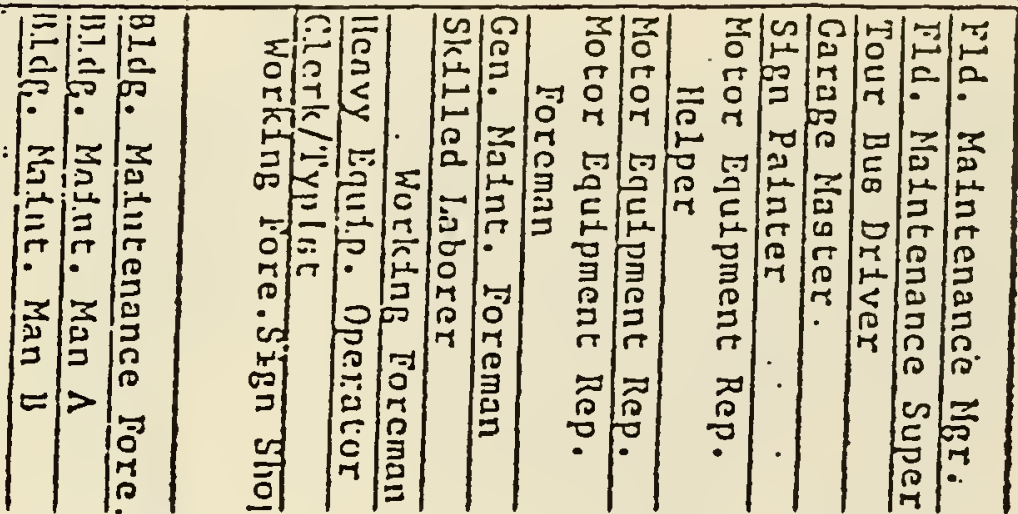

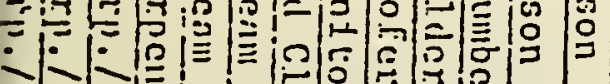
₹ לे

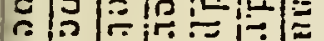

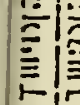

告

$x>$

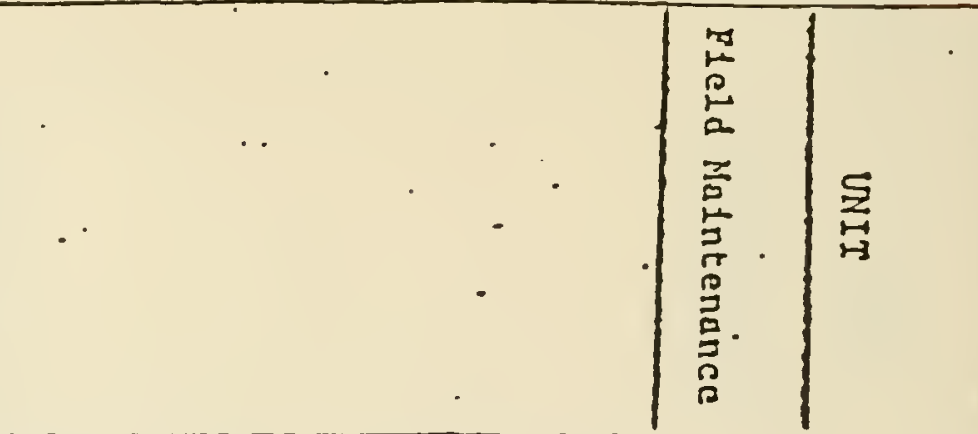

年

$\mid$

\section{E}

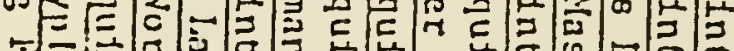

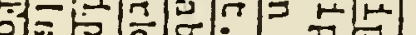

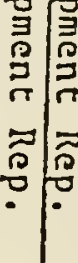

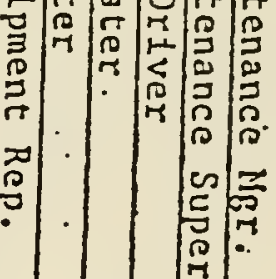

)

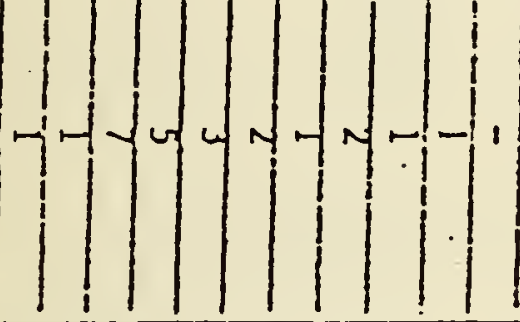

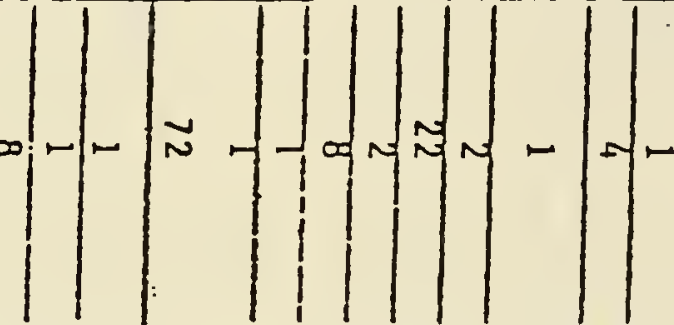

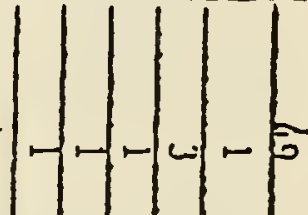

(1)

\begin{tabular}{l|l|l|l|l|l|}
1 & 1 & 1 & 1 & 1 & \\
1 & 1 & 1 & 1 & 1
\end{tabular}

$\int_{1} i_{1}$

1,1

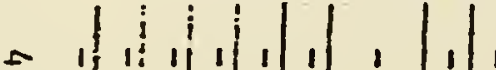

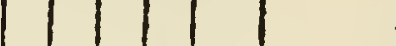

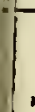

fr.

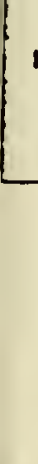




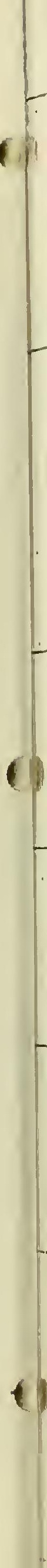




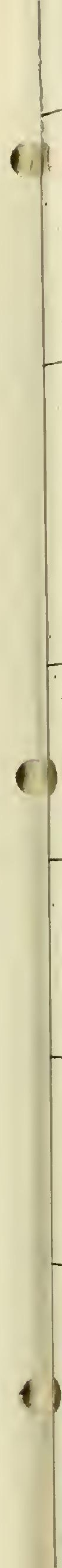




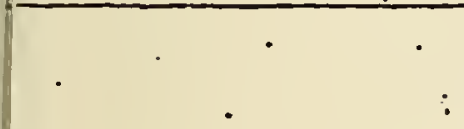

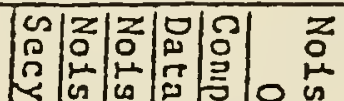

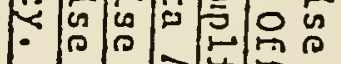

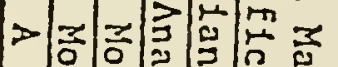

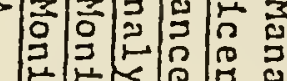

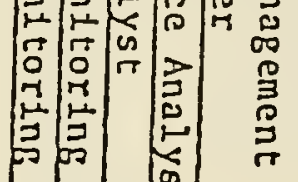

)

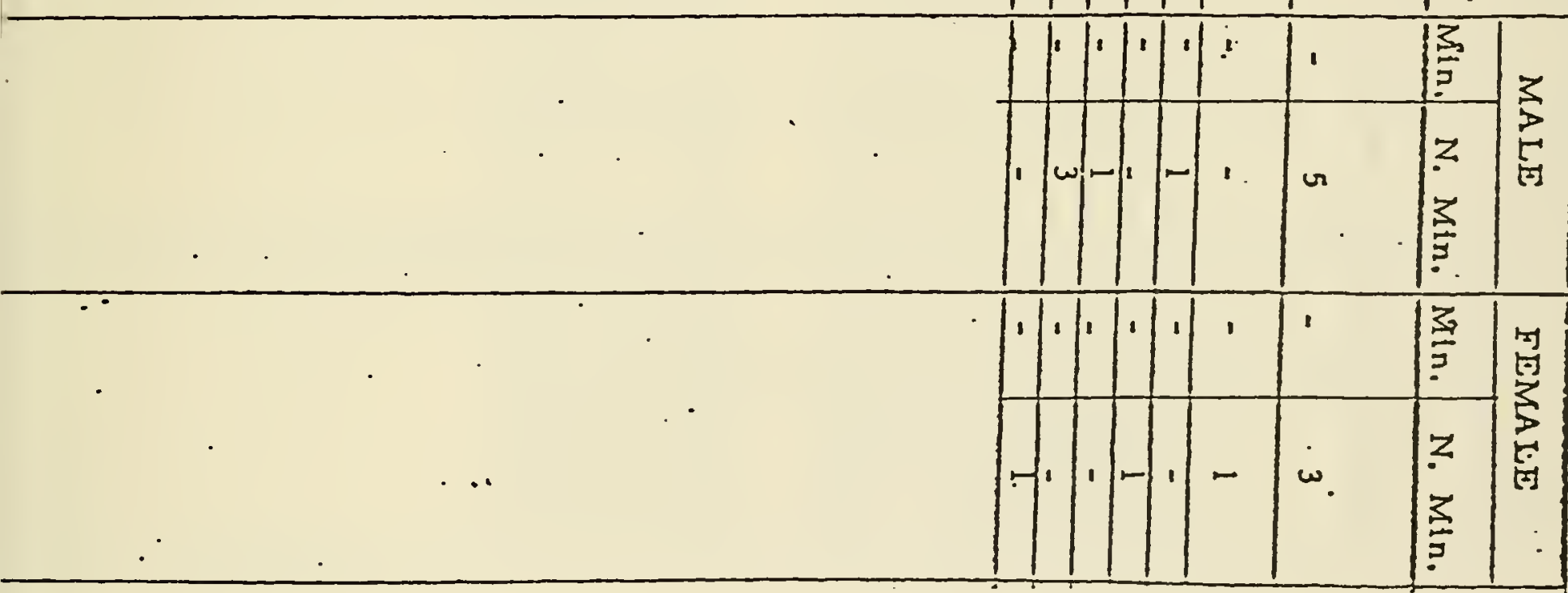



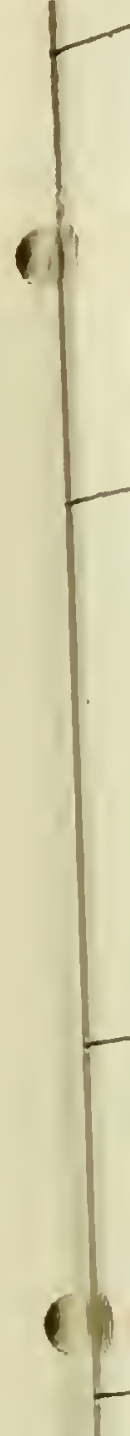


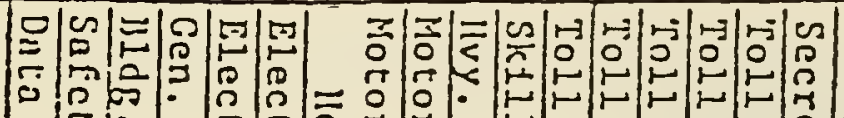

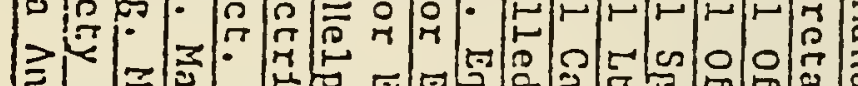

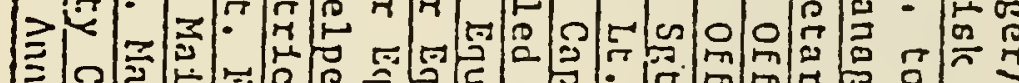

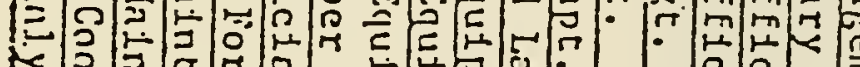

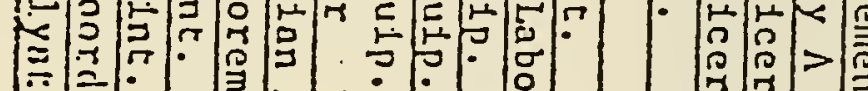

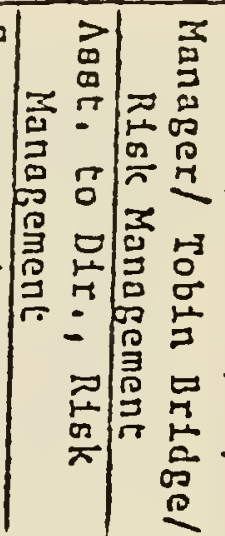
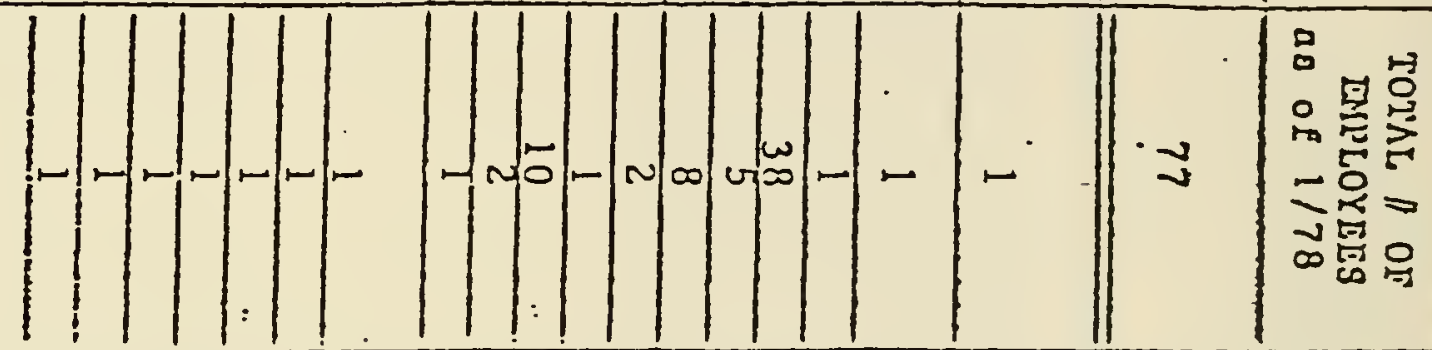

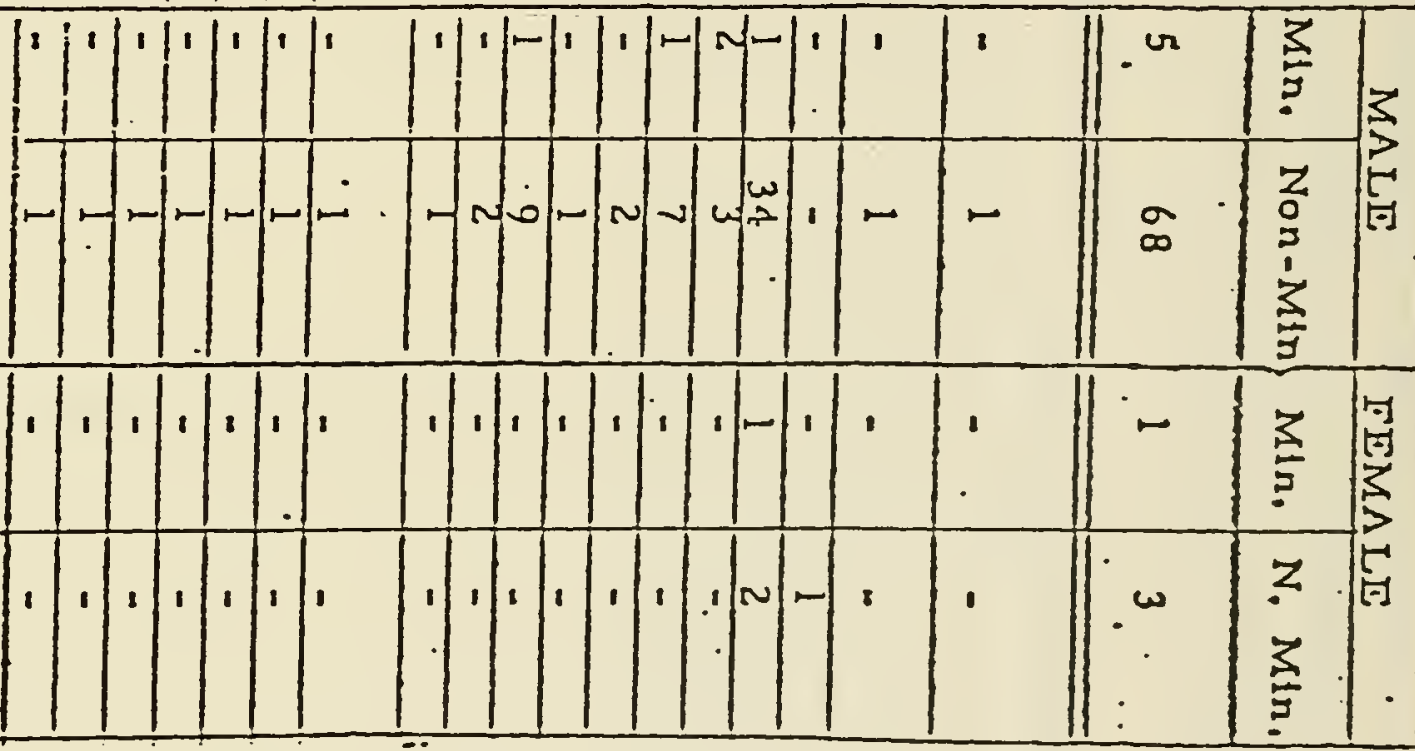


(i)

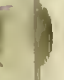

$-$ 


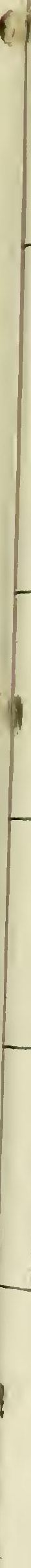




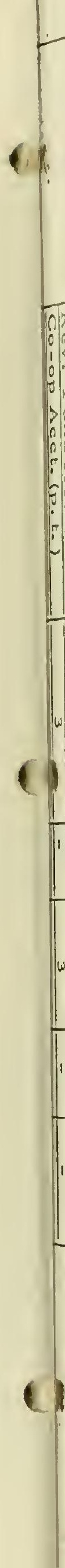




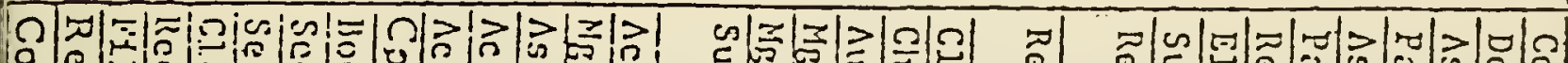

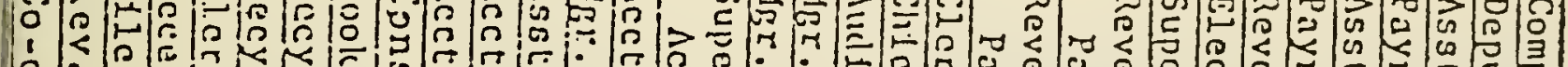
o

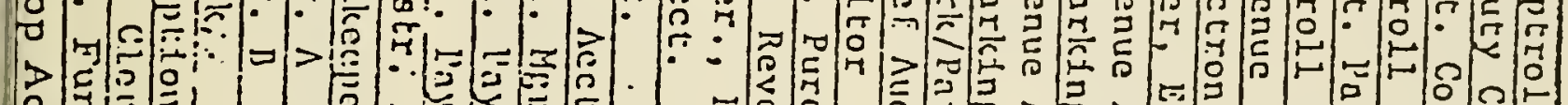

年

$\because>$

דิ

เT

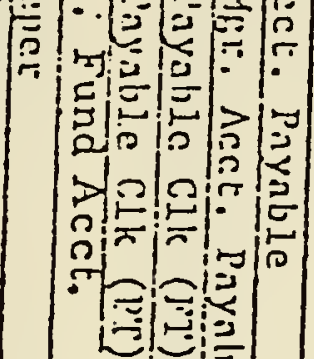

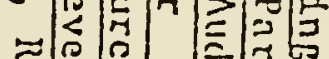

टे

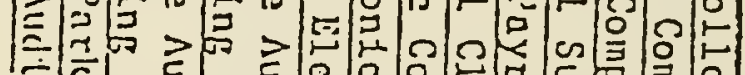
-

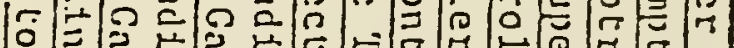
- ra o 光

$\omega$ NoN $N$ 1 11
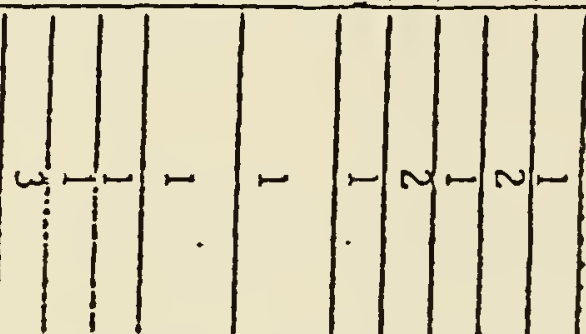

1

(1)
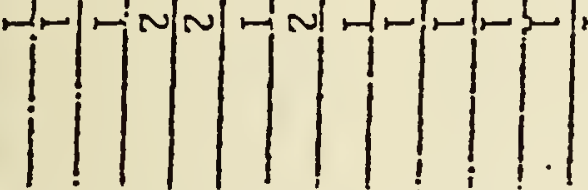

$:$

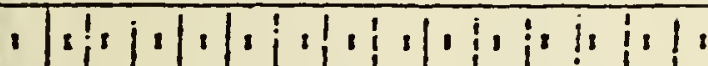

$1 ! 1, i, j$

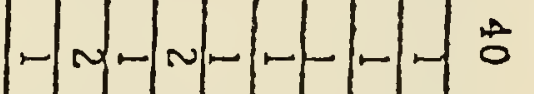

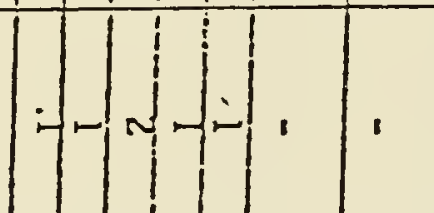

$-1$

$.1 .1 .1,1$

1

1.1 .1$.

1

$-1$

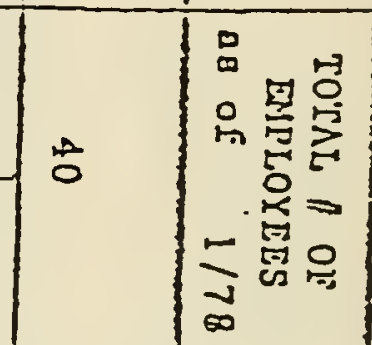
.

, 


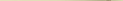




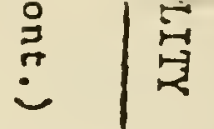

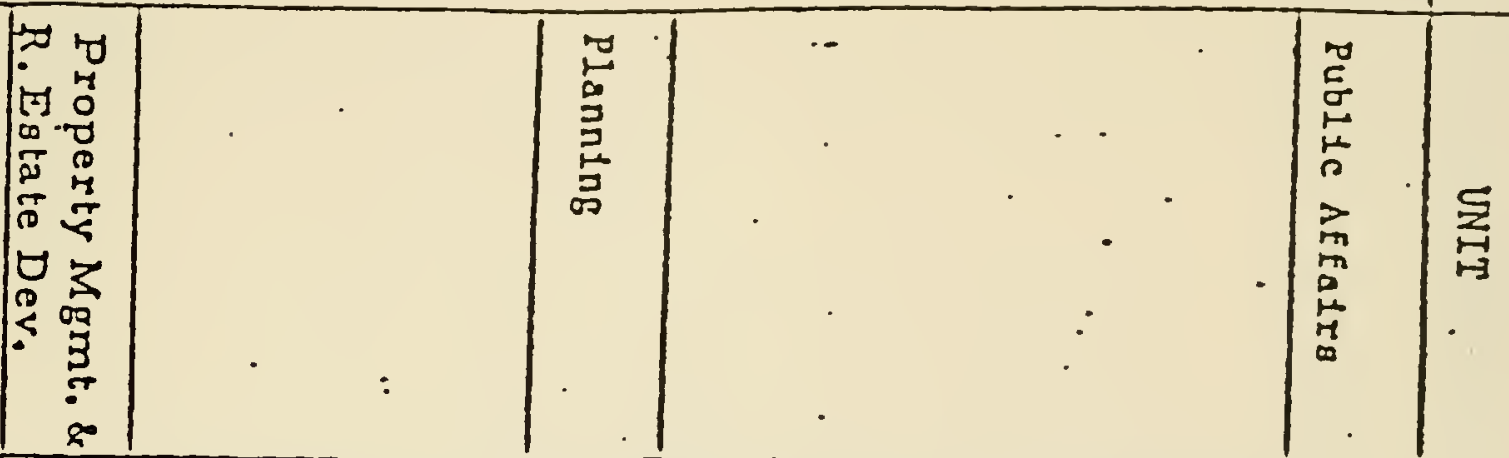

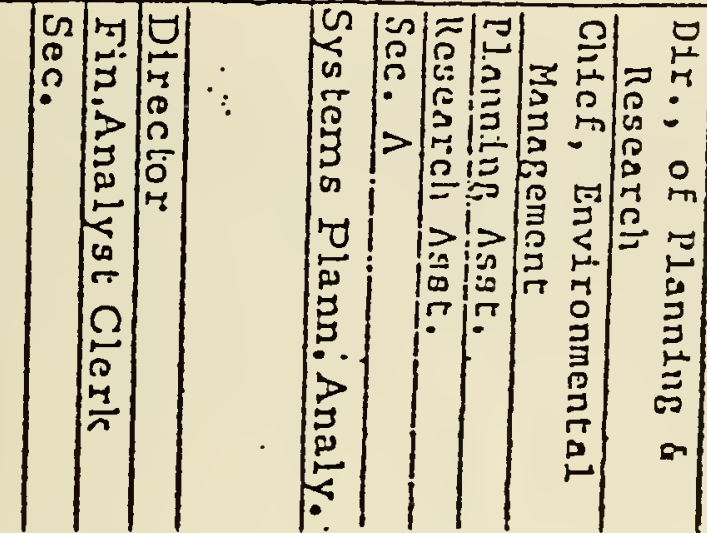

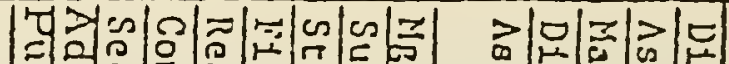

국일

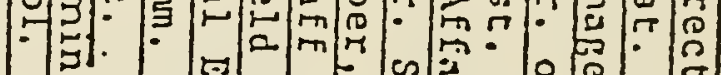

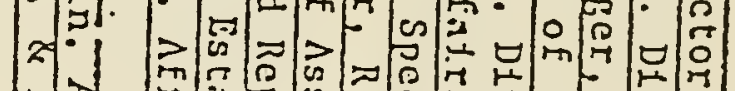

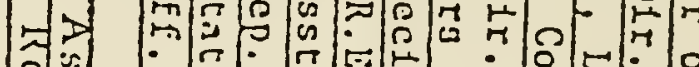

象

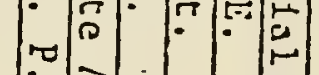

- $=0$

ב

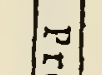

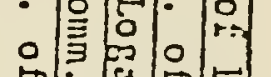

$m ? \begin{array}{lll}0 \\ 0\end{array}$

$\delta \rightarrow=$

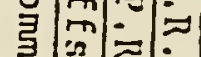

约

马) $=27$

동

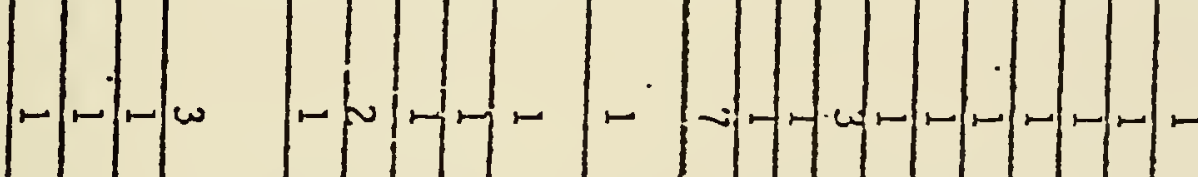

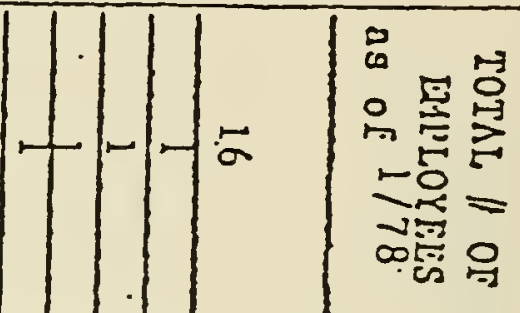

$1,1,1$

in $i i_{1}$

$\cdot$

1): 12

$1.1 .1: 1$.

.

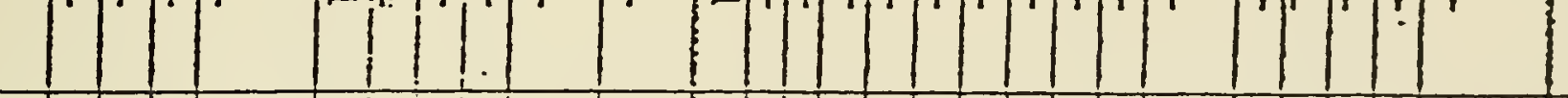

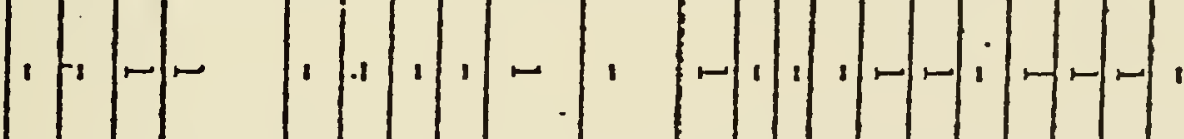

$\iint_{0} \frac{z}{2}$

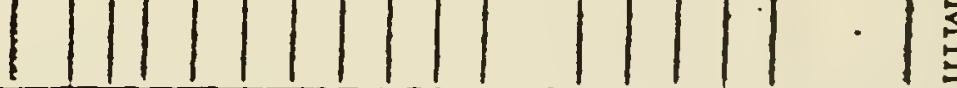

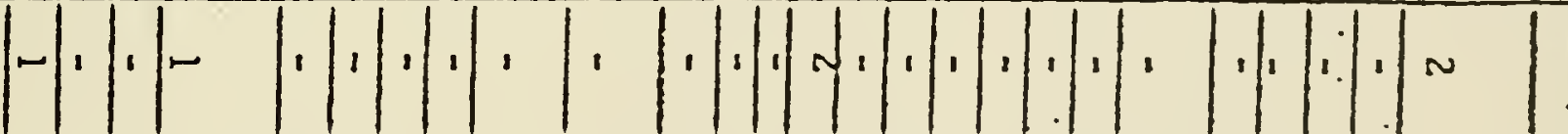

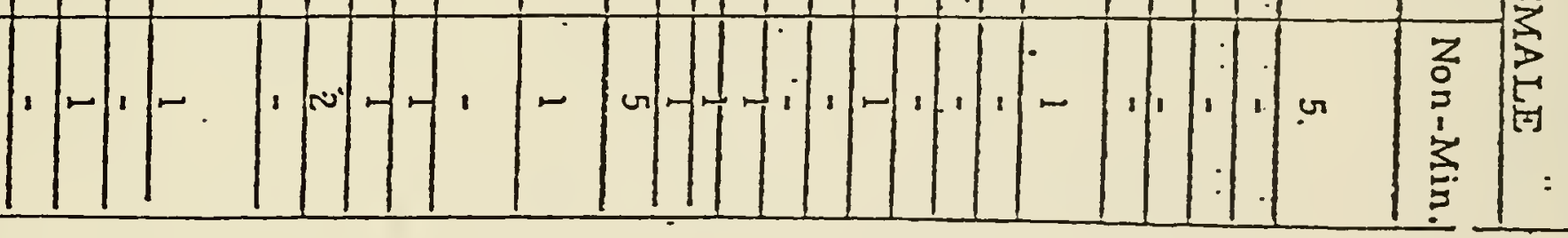




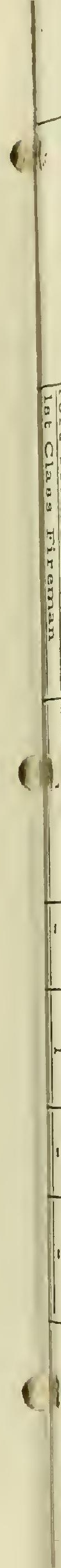



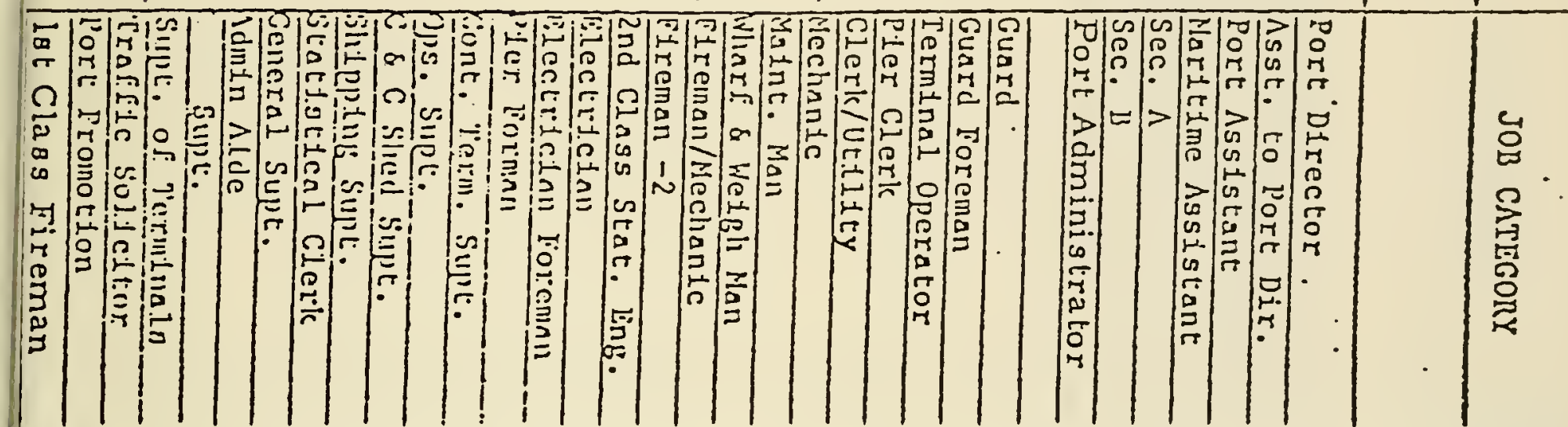

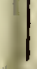

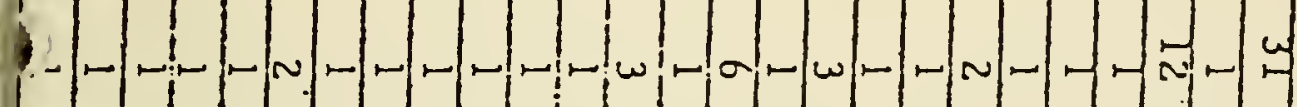

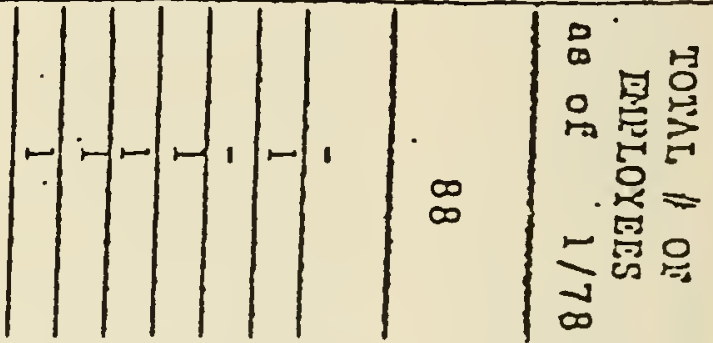

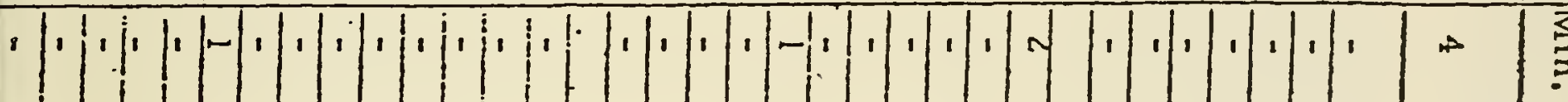

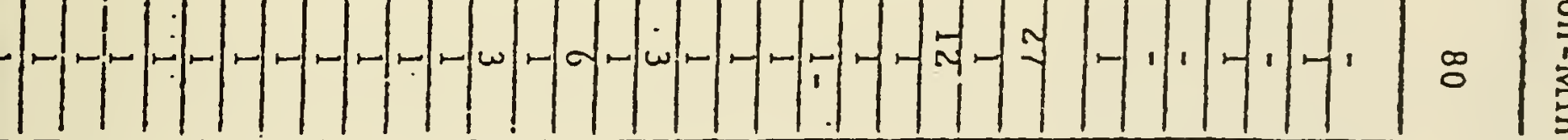

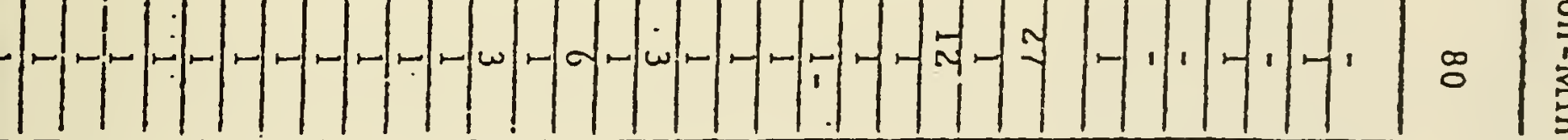

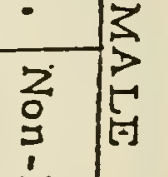

.i.ji:.1.1.

.1 .1 .1 .1 .1 .1$.

1.1 .1$.

1.1.

1.1 .1 
(1)

1

(1) 


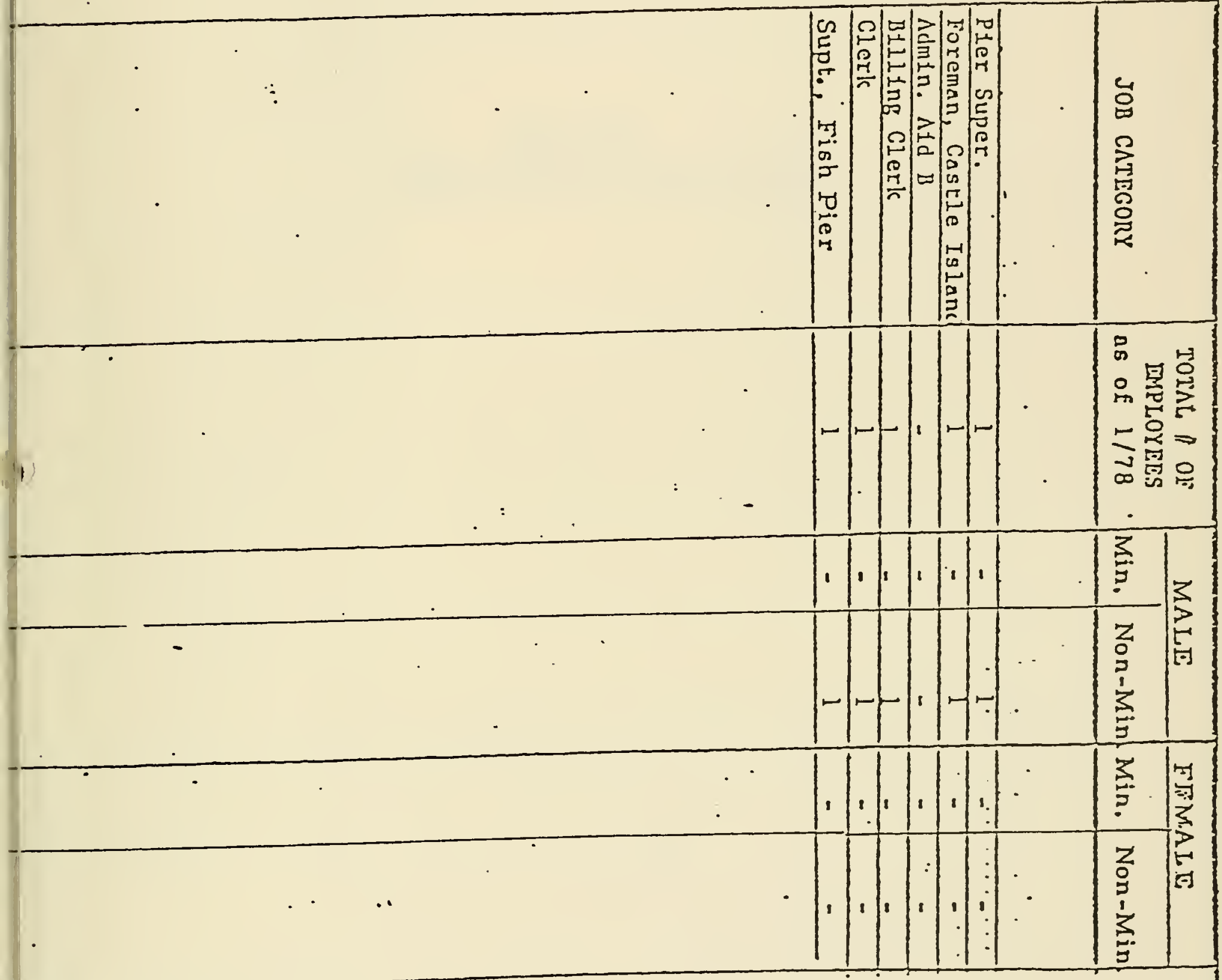


(1)

(1)

1 


\section{Section VI \\ Equal Economic Opportunities

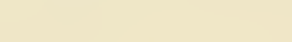

- 
Ia It is the policy of the Massachusetts Port Authority to increase the level and ality of participation by minorities and women in its economic opportunities. This 11 be achieved by using relevant equal opportunity and affirmative action guidelines d provisions established for state agencies by the federal government, the mmonwealth of Massachusetts, and the Authority as they are presently in force as may from time to time be promulgated or amended. The Authority requires an enforceable provision of contract or lease, equivalent affirmative action ograms of its contractors and lessees and as a condition of bid or sale in rchasing goods and services.

\section{Lessees and Concessionaires}

The goal for 1978 is to identify minority investors and operators for no less than ajor concessions at Logan Airport. The Authority will continue to make substantial firmative action efforts to contact and encourage qualified minority and female itrepreneurs to compete for leases and concessions and will grant at least equal insideration with other contractors. The target goal is a minimum of 20 percent of e overall dollar volume of the Authority's leases and concessions. However, since ine of the Authority's major tenants, the airlines and auto rental agencies are 50 percent male or minority-owned, a larger percentage of the non-airline and non-auto rental isiness shall be set aside for negotiated contracts with minority and female owned operated businesses. Interim determinations of this proportion will be based on a udy of what proportion of the Authority's dollar volume is made up of non-airline, or to rental business, and lease and concession availability. The lessees and sncessionaires and the Authority's major long-term tenants are encouraged to adopt milar programs.

\section{Goods \& Services}

A substantial proportion of Massport's contracts and purchase orders for goods ad services will be let to minority and female contractors. The goal is a minimum of $0 \%$ of the dollar volume of contracts and purchase orders for goods and services. This roportion excludes the cost of services and goods such as utilities, telephone, tevedoring services, etc, , where no identifiable minority or female capabilities xist at present. 
Cissi

tit

(1)

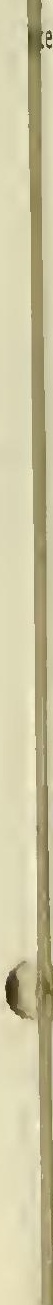


Goods \& Services (cont'd).

The Authority's purchasing staff, with the assistance of the Equal Opporturity lasing Specialist hired 10/77, has identified those categories of goods and services ch we are aware of minority or female capabilities. As a result of this process the rity's goal for 1978 is $\$ 354,000$. As new capabilities are identified, they are added I bidding lists and this information is forwarded to the appropriate staff members.

In an effort to maximize the participation of minority and female firms in our lasing activities the staff has been utilizing the following types of procedures:

1. - selective set-asides for minority bidders

2. - direct negotiation

3. - joint ventures between minority and non-minority firms

As pari of its effort to increase and stay abreast of development in the minority less sector, the Authority has become a member of the New England Minority hasing Council. Activities in the Council include the attendance of the Equal rtunity Purchasing Specialist and appropriate staff members, at minority sitions, minority matchmaker programs, and periodic seminars. The Equal rtunity Purchasing Specialist and other staff involved in purchasing will utilize linority business data and listings of the New England Minority Purchasing cil to supplement Massport's listings and data.

The Authority will continue to utilize local and regional minority technical assistanc ps as additional sources of information and identification of minority business capabiliti techrical assistance groups include, but are not limited to:

1. - Small Business Development Corporation

15 Court Street

Boston, Mass. 02119

2. - State Office of Minority Business Assistance

Executive Office of Communities \& Development

100 Cambridge Street - 13 th floor

Boston, Mass. 02202

3. - Office of Minority Business Enterprise

Regional Office..

441 Stuart Street - 10th floor

Boston, Mass. 02116

4. - Nelson Peters \& Associates

89 Broad Street

Boston, Mass.

5. - Lewis H. Latimer Foundation

133 Mt. Auburn Street

Cambridge, Mass, 02138 
In addition, language has been developed by the Compliance Office which will be used as a condition of bid or sale in which the bidder or vendor must:

1. - Attest to a non-discriminatory employment policy at all job levels and files a breakdown of its employees by race and sex at all job levels. This profile must meet the standards of the affirmative action policy set forth by the Massachusetts Port Authority and reflect the percentages recommended by the Massachusetts Commission Against Discrimination for female and minority employment for Massachusetts cities and towns. The applicable percentages will depend on the location (s) of the vendor's place of business. These standards will become a routine part of the specifications for every contract or purchase order for goods and services.

If the vendor's profile does not meet the standards set forth by the Authority's Affirmative Action Program and the Massachusetts Commission Against Discrimination the vendor or bidder must:

2. - Submit to the Authority an affirmative action plan which meets the standards set forth by the Massachusetts Port Authority, consistent with the minimum minority and female percentages applied by the Massachusetts Commission Against Discrimination for the city of Boston and other cities and towns of the Commonwealth. The bidder or vendor must demonstrate that every possible measure has been and shall be made to eliminate any discriminatory barriers in terms and conditions of employment on the grounds of race, color, religion, creed, national origin, age or sex and to eliminate and remedy any effects of such discrimination in the past. Such affirmative action shall entail positive and aggressive measures to ensure equal opportunity in hiring and all other terms and conditions of employment. Bidders and vendors will be notified that their performance under this condition of bid or sale will receive major consideration in Massport's selection of vendor or contractor.

\section{Gonstruction Contracts}

As required by Administrative Bulletin 75-14, every construction contract including maintenance and repair work and other labor intensive contracts let by Massport, or by any of its contractors, lessees or concessionaires will be required to include an equivalent version of the Commonwealth's Supplemental Equal Employment Opportunity Anti-Discrimination and Affirmative Action Program as approved by the Massachusetts Commission Against Discrimination. 
The Authority has a goal of not less than $20 \%$ ratio of minority employee arson-hours to total person-hours in each job category based on the percentage minority residents in the population of the City of Boston plus the neighboring Pacted communities of Chelsea, Revere and Winthrop. However, the minority tilization requirement is $10 \%$ in conformance with the Commonwealth's formula.

The Authority is maintaining a list of qualified minority and female contractors, rith constant updating. Efforts to assure the involvement of minority and female ontractors consists of clauses in selected cortracts which require minority/female ontractor participation. Such clauses require a minimum standard for minority nd/or female contracting involvement. The identification of the specific contracting nd sub-contracting opportunities will be consistent with the capabilities and levels of ompetence of the female and minority contractors available to the Authority through ts contacts and direct experience.

In March of 1978, the U.S. Department of Transportation issued DOT Order Jo. 4000.7A concerning the effective implementation and enforcement of minority usiness enterprise programs. As part of our efforts to implement equal opportunity nd affirmative action policies that will be compatible with this order, the Authority s establishing an advisory committee to assist in the development of contracting ioals, procedures, and appropriate contract language. The Committee will be composed if Massport staff as well as representatives from public and private organizations and gencies at the Federal, State and Local level. 

EXCIUDE SCHOOL SYSTEMS ANO EDUCATIONALL IM!STITUTIONS

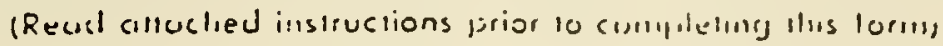

A. TYPE OF GOVERNMENT (Check one box only)
1. Sicule
2. Coun'y
3. Ciry
[4. Torens:rop
5. Special district

8] o. Other ispecily:

Political Sub-Division

\title{
8. 10ENTIFILATION
}

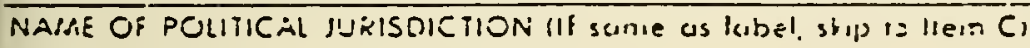

\section{Aikiress. Number und Sireal \\ 99 High Sirset}

\begin{tabular}{|l|l|l|} 
CliYiturh & STATE, ZIP \\
Boston & SuIfolk & MA 02110 \\
\hline
\end{tabular}

\section{FUNCTION}

Chest ens bied 10 incics:e the functien for which this form is being submilled. Dalo should be reported lor oll deperiments ond

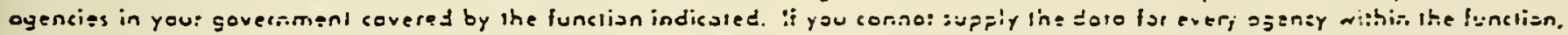
pleose alloch o list shewing name end odöress ol ogensies whase ceto cre nol inciucied.)

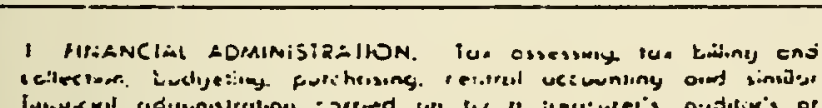

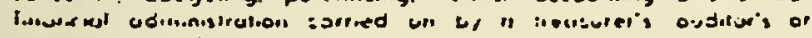
cunviratier's ullate und

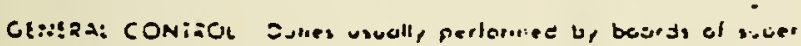

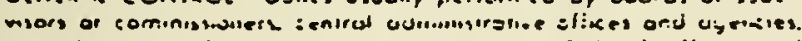

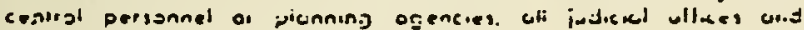

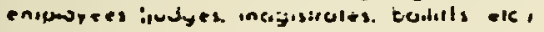

whos

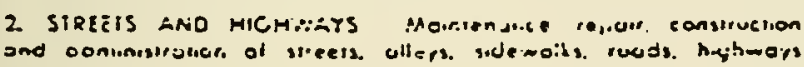
and oonionis brivi jes

\section{$\cdot 1$}

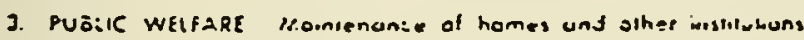

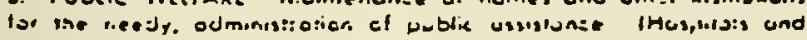

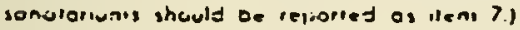

- POICE PRUIEETION Dures al a zaice depurment, hetilts.

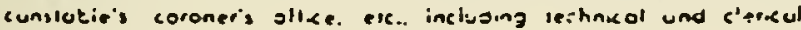

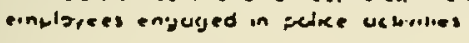

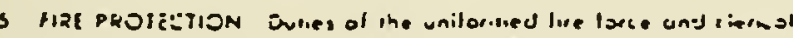

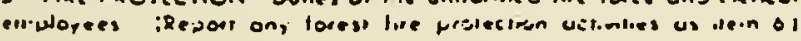

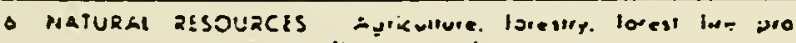

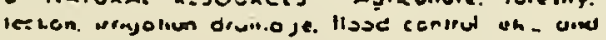

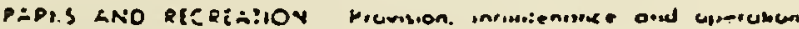

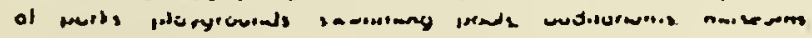
nociume. aci. el:

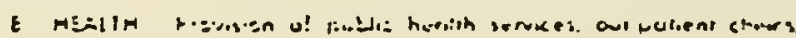

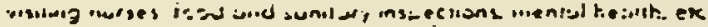

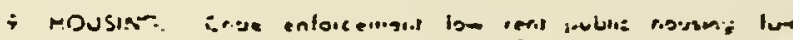

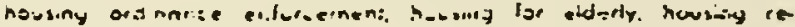

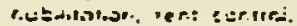

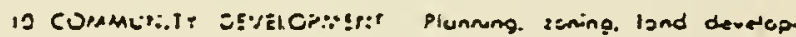

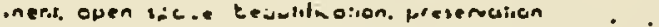

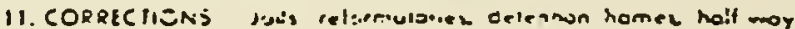

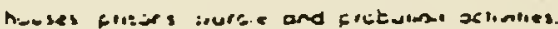

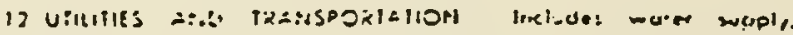

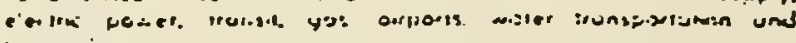
ieinionoil

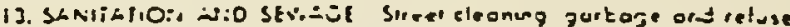
collezion uno d siogil Fromkm. n.omienune dod doerution nt

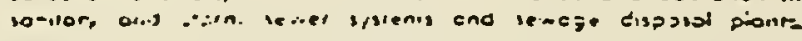

\section{It Etrp:or:?t::i StCuksur}

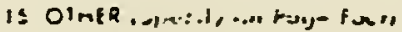





\begin{tabular}{|c|c|c|c|c|c|c|c|c|c|c|c|c|c|}
\hline \multirow{4}{*}{ 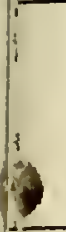 } & \multirow{4}{*}{ 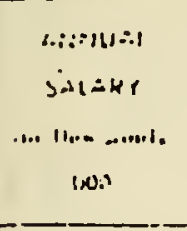 } & \multirow{4}{*}{ 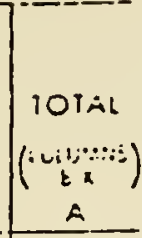 } & \multicolumn{5}{|c|}{ - } & \multicolumn{5}{|c|}{ 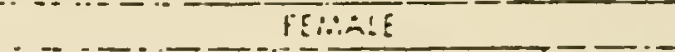 } & \\
\hline & & & \multicolumn{2}{|c|}{ 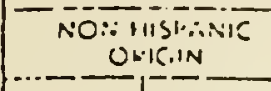 } & \multirow{3}{*}{$\begin{array}{c}D \\
D\end{array}$} & \multirow{3}{*}{ 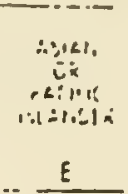 } & \multirow{3}{*}{ 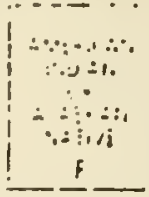 } & \multicolumn{2}{|c|}{ 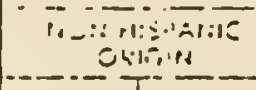 } & \multirow{3}{*}{ nes:i:Li: } & \multirow{3}{*}{ 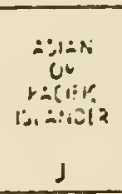 } & \multirow{3}{*}{ 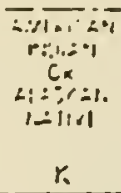 } & \\
\hline & & & xniti & & & & & $\therefore \ldots:: !$ & $t: \therefore$ & & & & \\
\hline & & & -8 & 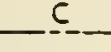 & & & & G. & H & & & & \\
\hline & $\operatorname{sos} \theta$ & $-\cdots$ & & & & - & ! & & & & & & \\
\hline & 6021 & & & & & & 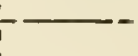 & & & & & & \\
\hline & 8040 & & & & & 1 & 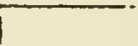 & 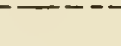 & & & & & \\
\hline & $10012^{\circ}$ & & & & & & & & & & • & & \\
\hline & $13015 \%$ & 1 & 0 & 0 & 0 & $\overline{0}-$ & $\overline{0}$ & I & 0 & 0 & 0 & 0 & \\
\hline & 10082 & 16 & 15 & 1 & 0 & 0 & 0 & $\overline{0}$ & 0 & 0 & 0 & 0 & \\
\hline & 250 mius & 29 & 25 & 2 & 0 & 0 & 0 & 2 & 0 & 0 & 0 & 0 & ? \\
\hline & 0139 & & & & & 1 & 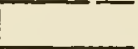 & & & & & & \\
\hline 1 & 2030 & & & & & $i$ & & & & & & & \\
\hline & 0019 & & & & - & $\vdots$ & 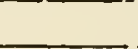 & & & & & & \\
\hline & 30.08 & & & & & $\vdots$ & 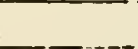 & & & & & & $\cdot$ \\
\hline 1 & $102: 20$ & 10 & 7 & 0 & 1 & 0 & 0 & I & 1 & 0 & 0 & 0 & ? \\
\hline & 130150 & 11 & 11 & 0 & 0 & 0 & 0 & 0 & 0 & 0 & 0 & 0 & $\vdots$ \\
\hline & 100.214 & $\leq 7$ & 37 & 2 & 0 & 11 & 0 & 7 & 0 & 0 & 0 & 0 & \\
\hline & 250 rius & 5 & 5 & 0 & 0 & 0 & 0 & C & 0 & 0 & 0 & 0 & \\
\hline & 0130 & & & & & 1 & & & & & & & \\
\hline & $=030$ & & & & & 1 & & & & & & & · \\
\hline & $00>0$ & & & & & 1 & & & & & & & \\
\hline & 305 & 5 & 4 & 1 & 0 & $0 !$ & 0 & 0 & 0 & 0 & 0 & 0 & \\
\hline & 100120 & 15 & 12 & 3 & 0 & 0 & 0 & 0 & 0 & 0 & 0 & 0 & $11=$ \\
\hline & $13=13=$ & 10 & 8 & 1 & 0 & 0 & 0 & 1 & 0 & 0 & 0 & 0 & \\
\hline & 10102324 & 6 & 6 & 0 & 0 & 07 & 0 & 0 & 0 & 0 & 0 & 0 & \\
\hline & $\because 0$ pius & & & & & $i$ & & & & & & & \\
\hline & 0130 & & & & & 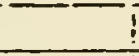 & & & & & & & $=$ \\
\hline ? & $\therefore 0 \leq 6$ & & & & & $\vdots$ & ? & & & & & & i \\
\hline & 0079 & & & & & $i$ & & & & & & & it \\
\hline & 8044 & 2 & 2 & 0 & 0 & $0 \div$ & 0 & 0 & 0 & 0 & 0 & 0 & \\
\hline & 100189 & 42 & 39 & 2 & 0 & 0 & 0 & 1 & 0 & 0 & 0 & 0 & 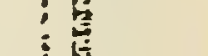 \\
\hline & 130150 & 30 & 30 & 0 & 0 & $0 \div$ & 0 & 0 & 0 & 0 & 0 & 0 & 贺 \\
\hline 3 & $1002: 6$ & 15 & 15 & 0 & 0 & $0 \div$ & -1 & 0 & 0 & 0 & 0 & 0 & 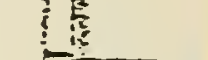 \\
\hline & 250 plus & & & & & i & & & & & & & \\
\hline & 0139 & & & & & $!$ & & & & & & & \\
\hline & 3.058 & & & & & & & & & & & & 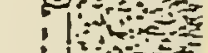 \\
\hline & 60.70 & & & & & & & & & & & & \\
\hline 3 & 3099 & 6 & 2 & 0 & 0 & 0 & 0 & 4 & 0 & 0 & 0 & 0 & \\
\hline & 100.129 & 9 & 7 & 0 & 0 & 01 & 0 & 2 & 0 & 0 & 0 & 0 & $=0$ \\
\hline & 130159 & 1 & 1 & 0 & 0 & 01 & 0 & 0 & 0 & 0 & 0 & 0 & 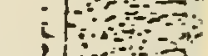 \\
\hline 3 & 100280 & 1 & 0 & 0 & 0 & D & 0 & 1 & 0 & 0 & 0 & 0 & $=$ \\
\hline . & 250 fiUs & & & & & & & & & & & & +5 \\
\hline 8 & $013 \%$ & & & & & & & & & & & & 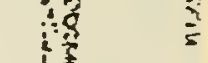 \\
\hline & 2034 & & & & & & & & & & & & t? \\
\hline & 0074 & 25 & 3 & 0 & 0 & 0 & 0 & 15 & 5 & 1 & 1 & 0 & ! \\
\hline & .0000 & 27 & 1 & 0 & 0 & 0 & 0 & 25 & 1 & 0 & 0 & 0 & $\frac{2}{1}$ \\
\hline & 100129 & 30 & 8 & 0 & 0 & 1 & 0 & 20 & 1 & 0 & $0^{-1}$ & 0 & 5 \\
\hline & 130159 & 3 & 2 & 0 & 0 & 0 & 0 & 1 & $0^{\circ}$ & 0 & $\sigma$ & $0^{-}$ & 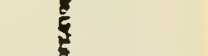 \\
\hline & $100 ? 20$ & & & & - & $--i$ & $\ldots$ & --1 & _ & $\ldots$ & & & VF- \\
\hline & anoule & & & & & & & & & & & & \\
\hline
\end{tabular}




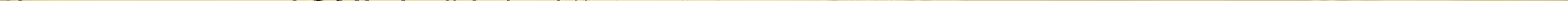




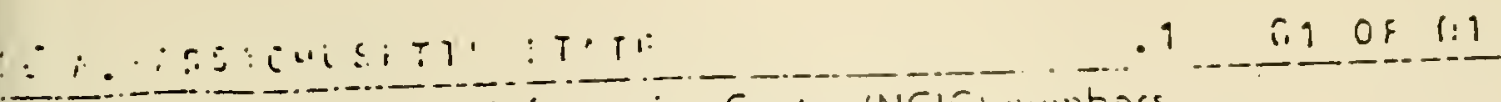

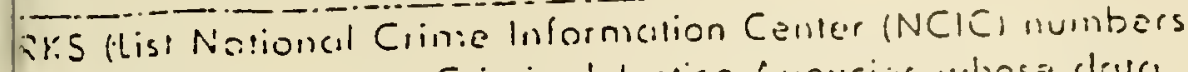
cassigned to ciny Criminal Justice Luencies nhose derici are incluiled in this report.)

The Massachusetts Port Authority vas creatad as a political sub-division of the Commonvealth of Miasachusetis to provide for the issuance of revanue bonds payable solely from tolls and other revenues for the refinancing operation, improvement and development of the Tobin-Memorial Bridge, Logan International Airport, L. G. Fianscom Field and the Port of Boston.

ITIFICATION. I cerlify that the informution given in this refoor is correct and true to test of my knowledge and was reporled in uccordonce with recompennying inslruc. s. Wilfully fols e stotements on this report cre funisinuble by kiw. U.S. Code, Title 18. tion 1001.)

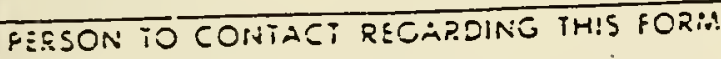

James W. Sullivan

is fidrroes and Sireel. Citj. Siute. Zip Codel

99 High Street: Boston, MA 02110

Director of Personnel 


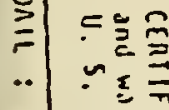

$\log _{\overline{0}} \overline{\frac{1}{3}}$

its

=늘

$=\overline{2}$

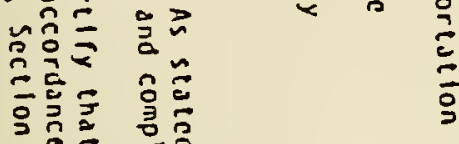

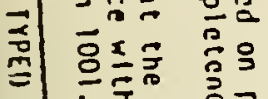

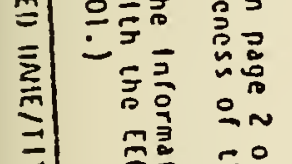

글

开 别高

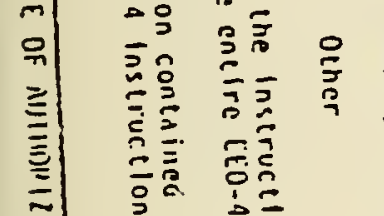

三

옥

年

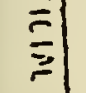

ำ

至完

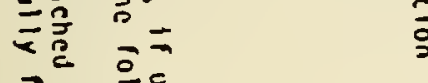

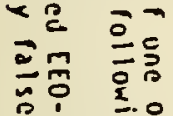

正

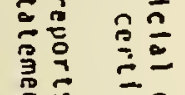

$\cong \quad \frac{\overrightarrow{2}}{\overline{0}} \bar{\vdots}$

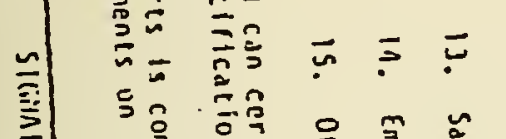

咅

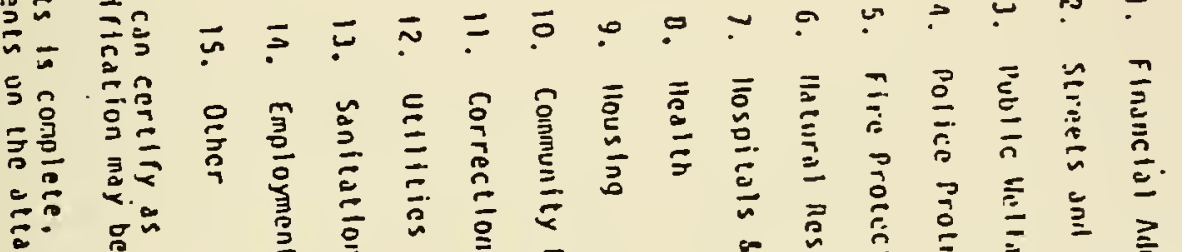

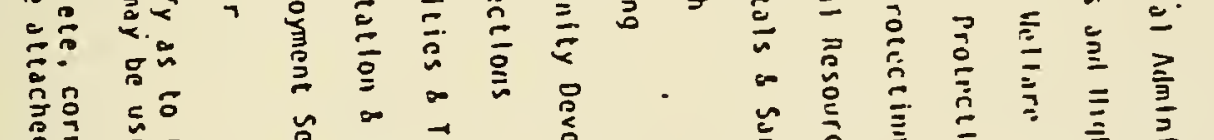

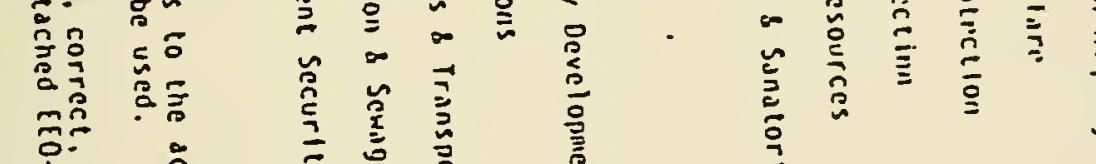

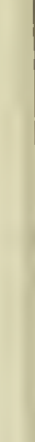

$\therefore$

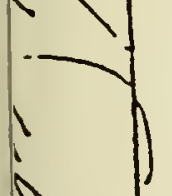

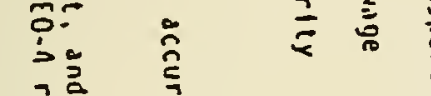

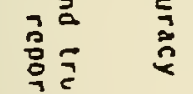

. (2)

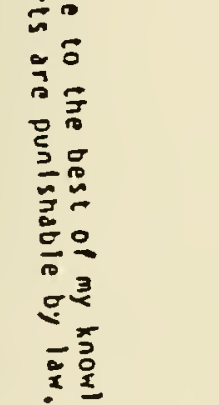




\section{EXHIBIT IV-3}

Rehabilitation of the Boston Fish Pier is given priority by planning units at all levels of state and local government. This project is not only included in the Boston Plan and the Overall Economic Development Plan for Boston, it is also included in the Metropolitan Area Planning Council's Overall Economic Development Plan and supported by the Massachusetts Office of State Planning.

The portions of these reports that deal with the fishing industry and Boston Fish Pier rehabilitation are attached in this section. 


\section{EXHIBIT $5 B$}

Rehabilitation of the Boston Fish Pier is given priority by planning units at all levels of state and local government. This project is not only included in the Boston Plan and the overall Economic Development Plan for Boston, it is also included in the Metropolitan Area Planning Council's Overall Economic Development Plan and supported by the Massachusetts office of State Planning.

The portions of these reports that deal with the fishing industry and Boston Fish Pier rehabilitation are attached in this section. 


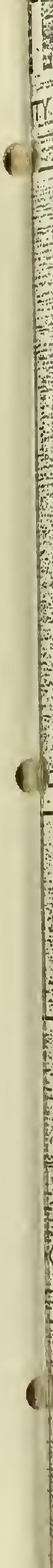




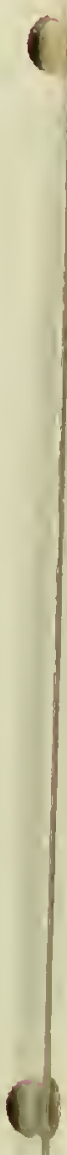




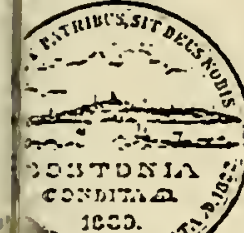

$16=0$.

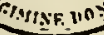

EVIN H. WHITE

Mayor
CITY OF BOSTON

OFFICE OF FEDERAL RELATIONS

ONE CITY HALL SOUARE

BOSTON, MASSACHUSETTS 02201
JOHN E. DREW

Director

$725-4224$

September 19,1977

Department of Commerce

Ecoironic Develomment Administration

600 Arch Sireet

Phieadelphia, PA.

Gensiemen:

As coordinator of Boston's major economic planning dociment, The Boston Plan, I would like to extend my wholeheshted support $=0$ Massport's application for Title I funding to renovate the Ecston Fish pier.

The Boston Fiain sepresents the most thorough and compienensive cojotis on the part of the City of Boston to integrate all ic zoston's physical and economic planning Efisots and Federii sinancial assistance into one exhaustive dockment. The sevitilization of the fishing industry in Boston is an integral part of our waterbront redevelopment planning; the renovation of the Boston Fish Pier is the first major step toward this goal. The $\$ 100$ million fishing industry cirrently provides employment for 1300 blue-collar workers, and is expected to cheate an additional 1000 jobs primarily for. low-s'silled and minority workers within the next decade.

Boston also has the potential for becoming the principle bish processing center for New England due to its location within the regional transportation network. The recently passed 200 -mile bishirg limit is expected to double fish catching within the next decade. Boston can capture this increased activity, and the resulting business investment in bish processing, wholesaling and related industries, with proper facilities at an expanded Fish Pier.

The renovation of the Fish pier is a significant step toward revitalizing Boston's economy, job base, and importance to the New England region. The Economic Development Administration will be making a major contribution to both Boston and the New Engtai region through the funding of this project.

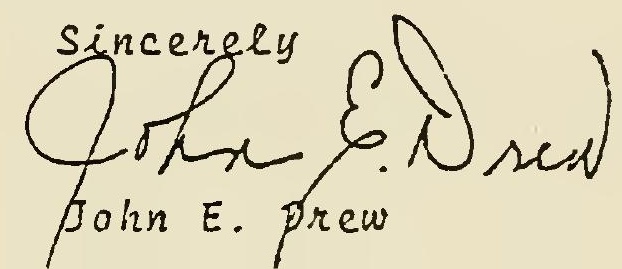


Fish Pier Rahabilitation

$$
[\because-39
$$




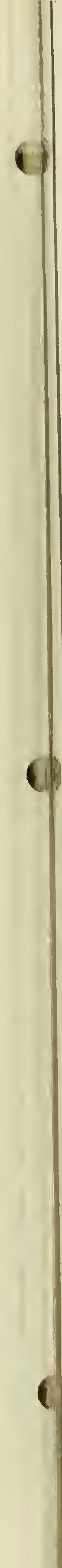




\section{Rahabilitation of the Fish Pier}

The Beston Fish Pier is the center of all fishing trensactions for the Boston metropolitan area. Fish are sold in the New England Fisi Exchange on the pier and filleted or frozen by processors located on the pier or on Northern Avenue. The Fish Piar was constructed in 1912 by the Commonweslth of Massachuserts. It was operated privately by the Boston Fish Markat Corporation until 1972 when Massport took over its operation.

During :-a last 30 years the condition of the pier and the is $=21$ fis-ing industry have declined. In 1965 there were 5? fising vessels operating from the Fish Pier; now there are 15.

Nevertheless the coming of the 200 mile limit and new financiai :-:erest in modern fishing boat acquisition has prcduzed naty hope for the revitalization of the fishing industry. Tr.z $i 300$ jobs eurrently at the pier ean be stablized and nisw : $=5 s$ sreated. The renewal of the Fishing Fleet nould rainitise ship repair activity at the nearby industrial park en: $=-$ : I in time generate new demand for refrigerated eontzinar $\equiv=0 \mathrm{i}$ wity.

\section{Sozejifi= =raigat}

This =rez=sal calls for reinvestment of 10-12 million in the puibisty Ewned Fish Pier ( 3.4 to $10.5 \mathrm{~m}$ EDA, 3.6 to 4.5 $m$ friesspori: . Recent studies of the pier have indicated serious probiens with the strustural integrity of the pier, the utility systen, structurss, and a need for new and more efficient lasting facilities.

Firs: phase rehabilitation will include:

- Rehabilitation of buildings 1 and 2 for use by Iish dealers and processors. The third floor of these buildings will be renovated for other compatible rent-producing uses, either residential or offics spacs;

- Rehabilitation of building 3 for eompatible incoms produce uses;

- Rehabilitation of the powser plant building to house centrar freezer cold storage, and heating facilities." It is also proposed that a naw fish unloading and auction facility be located here and that it would be an appropriate relocation site for an enlarged ics piant. These facilities are badly needed for growth of the pier's operations as well as for reasons of sanitation and effieiency. 
e 
- Rehabilitation of the pier iself is proposed and would include resurfacing tha apron and ragrading and paving the central street. The traffic and loading patterns would be revised to eliminate the present problems of congestion.

This rehajilitation would be phased to allow minimum disiuption of zier operatiens.

A secend major component of this project would involve c-edit assistzice for the Fishing Fleet. A new trawler now costs an svaraja of $\$ 1.6$ miliion and most of the existing Fleet is over 30 yeses old. As an undercapitalized high risk industry tra Fisn:- Fleet has been chronically unable to renew

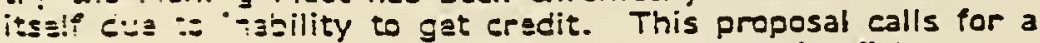
Feserally indied loan guarentee program to assist fishermen. Wo-king wit- lesal banks and the proposed guarantee program, ine City : Es Eston will offer technical assistance to fishermen io gain finstaing for new fishing boats.

\section{iimi:-}

Tha Fisi piar upgrading and loan guarantee program

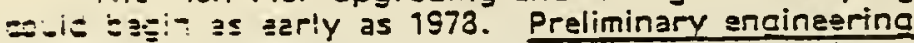

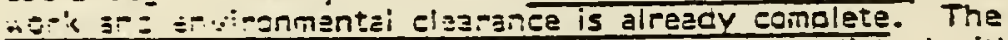
anire 2 yะz:-3

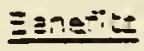

investant in the fish Fiar and the Fishing Fleet will nave a riajz- efiect on a major New England industry. Fish cresessinj winish traditionally employs a resident blue collar, grten mino-: $\because ;$, labor for $=3$ will be stabilized in Boston with a potantial :=- aesing 1000 new jobs to the present base of 1300. Bestre. has the potential for becoming the principle rish prosessing center for New England due to its location within the rosional transps-tation network. With the growth of the incustry because of the 200 mile limit, fishing could - couble its ieval of activity within the next decade. 
(1) 
THE BOSIOK

OVERALL ECONOMIC DEVELORMENT RROGRAM

13 amended

JANUARY, 1977

Mlebael Hesegaee, Chatzman

Ihe OEDP Coumitese
Haros, Kav12. I. Thise CIET of Boseon 


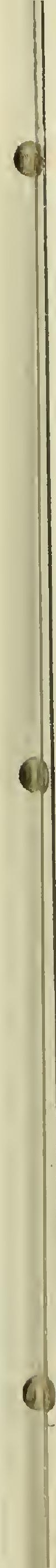


The Comittee is mandatad by the Economic Development saministration to develop an overall develogment plan for the City of Boston and to insure that the plans and projects of various organizations are in confornance with that plan. In addition, the OEDP Conmittee is comprised of a brode bassd aivisory group, which freols the bayor and the ivyor's Isvelogment and Industial Cemuission of comnunity and businesses' views on tise economy of the City: The comittee provides an outreach finction to assist comanity development corporations, and other ecsromic developant oriected groups, and to encouraga them to work is closer consort with the City of boston to the nutual benesit of all.

The OED? Connittee consisits of representatives of cemeinitiy organizations from several neighieoribods of the City, muricipe: levelopment agencies, local barks and businesses, as iell as political leaders. Working together, this group has foined many local talents and resources with City and Economic Development hiainistratior funds to meet the challenge of creating new fobs and Inproving the econonic basa of the city.

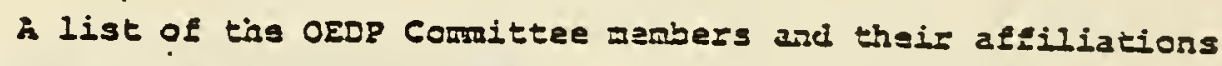
is attachod on the followirg page. 
To fulsill area goals, the strategy for economic development z:st Eocus on tije crsation of lfgit menufacturing and riarine-related

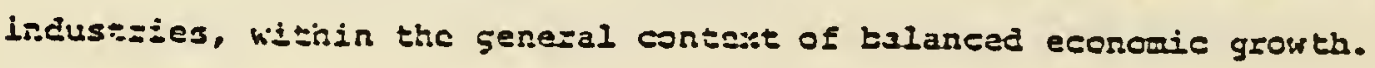
Tise prite nover in this cfiort will be the Esoromic Development: ind Injustrial ccaporation of eoston, but othar. zelated projects

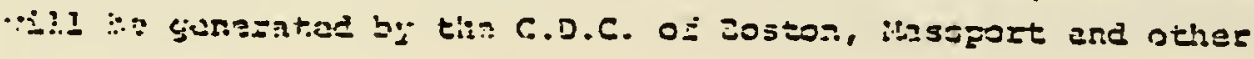

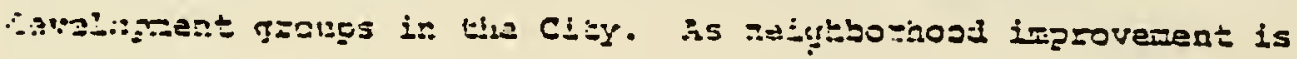

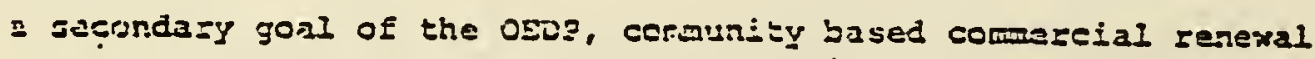
grojerso will also ba ensurzaged and supsortad.

ECIC is a quasi-pucic non-ozolit estooration created 33 =i:a action azm of the Developnert and Irjugtial cocuission, a City egency. 'sia corgoration has minent cemain powers in azeas

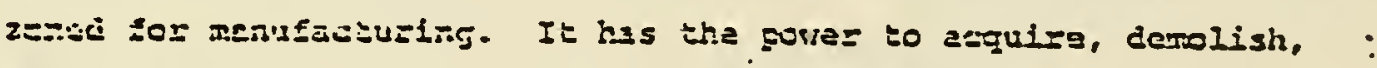
Ser.o:-1:a ard.or bufld lnciustial structares for sale or lease.

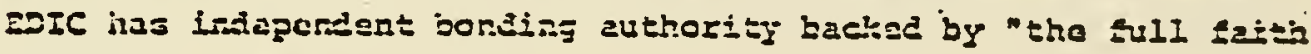
erd crasit of the City".

The projects that the OID? Comittas envisions coming en linss ovar tise next year are detaifed below.

\section{Crosetorn Ir:iustrial gara}

Phase I develcpirant of the sito, encompassing live acres of lard, is scieduled for implementution in 1977. The site is located in the Roxkury section of BO3ton and adjacent to the sourheast Expressway. Over 100,000 square feet of new lndustrinl spacs and 200 jobs are aptlcipated tron this phase of the develooment. The project will be cerrfed forwarc by EDIC in conjusction 


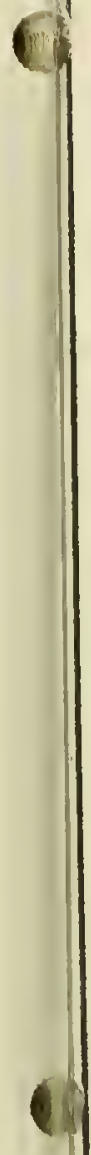


with the COC of goston and isvolva a $\$ 2$ million eagital investment eur açuisition site preparation and nes coistruction.

Eoston Eish Piez Uciesnization

Massport has Legun prelinirary Cissussioss vith EDA and OEgP represuntatives relative to codarnizing the Roston Eish Pies, wi:dit was originally constuctec in 1915. The moderzization progran

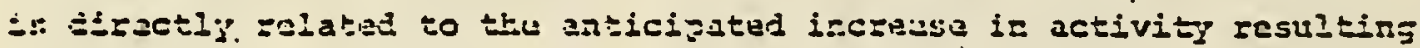

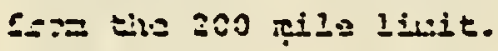

Tha Fish Pier is lscated in the heart of South Boston's

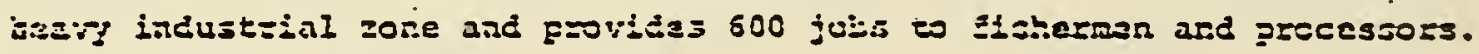
:i.: site has suffared f=or long naglect, as is tire case with nast

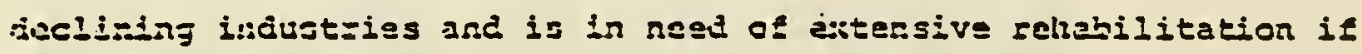
it's to raet the nmecis of insreased: orociltetzon. 
c)

6 
T: 


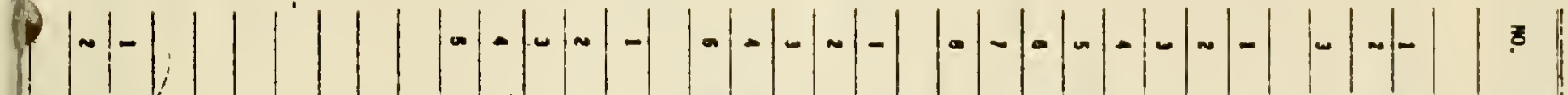

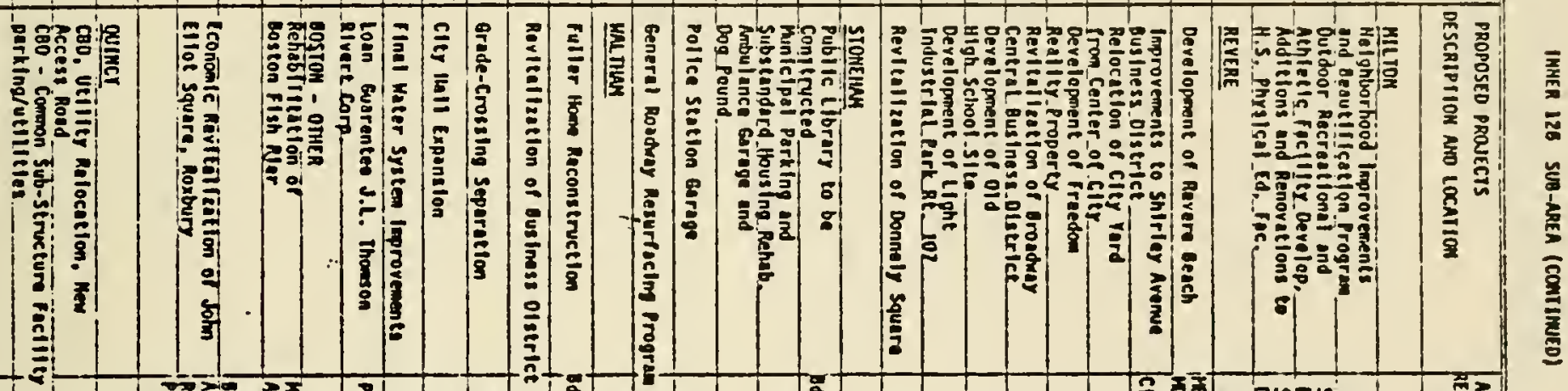

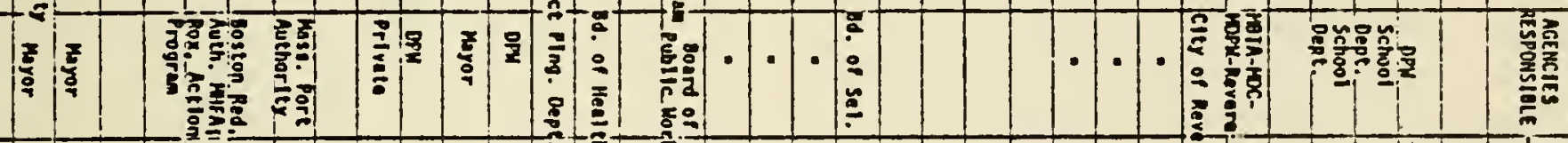

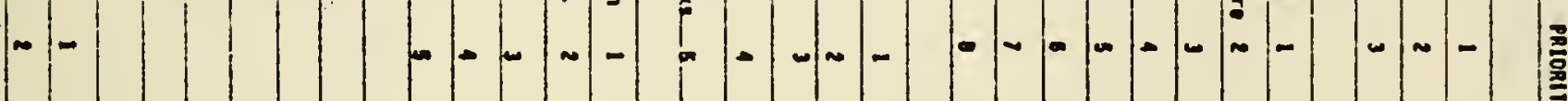
总 .

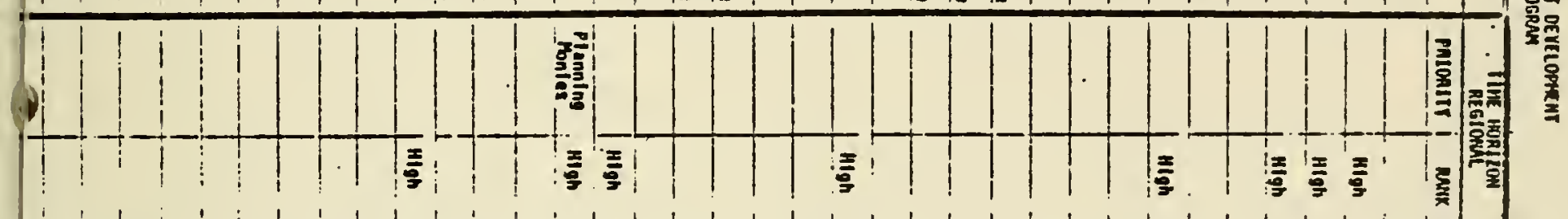

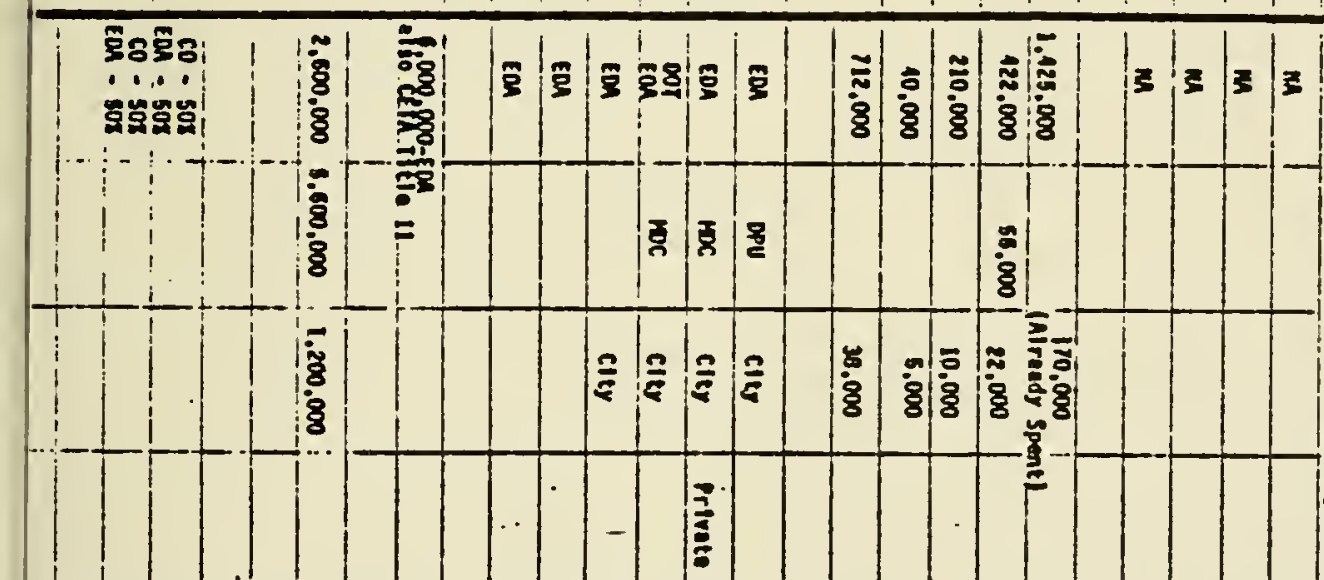

8 क

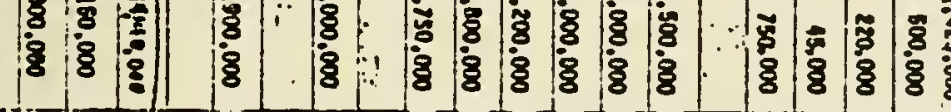

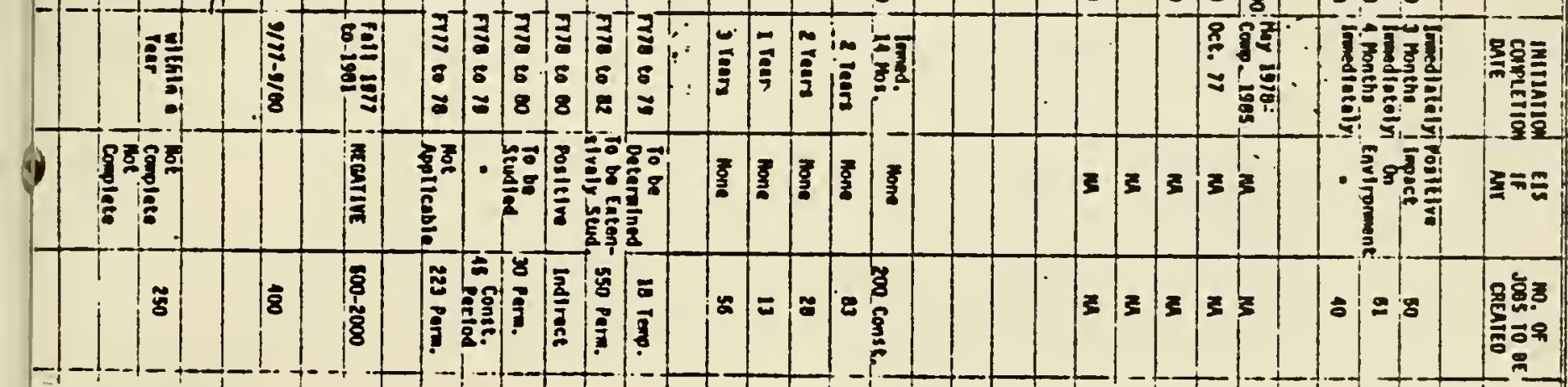

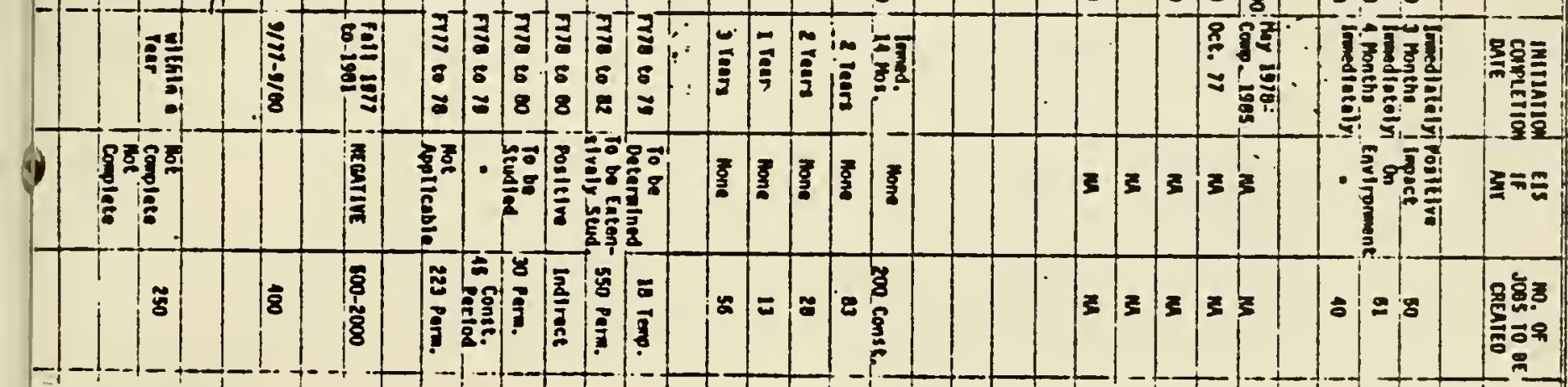

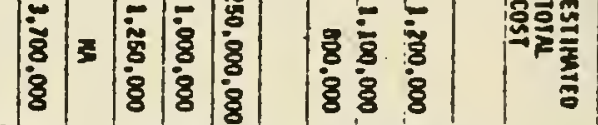




\section{THE COMMONWEALTH OF MASSACHUSETTS}

\section{EXECUTIVE DEPARTMENT}

STATE HOUSE - BOSTON 02133

Dear Fellow Citizen:

I an pleased to present you with this Econcmic Develooment Presrem for Miesszetinusetts.

The purpose of tis is document is to establish a common fremework in whicin to view the Ca-moniveal th's economic problems, and to encourace understanding of and support for the policies and prograns which best respand to these problems.

It is importznt to point out that this progren focuses on what stete sovernment can and -.ist te to spur economic grovith. f.s such, it does not dasl extensiveiy with ine important roles of the F $E$ deral Governient ard th tiel?

Federal reguiatery desisions end federal fasility investments prcfoundly iniiuence the level of economic activity in Massachusetes. He need look only to the powers of the ?Ecaral Reserve System and the white iouse in controlling monetary and fiscal policies, and of the Department of Defense in closing military bases and channelling research and development dollars, to appreciate the need for strongly supportive federal policies and programs. Moreover, mejer changes in federal policies with regard to full employment, netional health insurance, and welfare reform would dranatically improve the prospects for eccnomic growth in Massachusetts. In this light, Lieutenant Eovernor O'lleili's Office of Federal-state Relations takes on critical importance in its already successful effort to influence national decision-making as it relates to the Commonivealth's economic interests.

Assuming complementary federal actions and a state government which is sensfitive to the need for economic development, little can be zchieved without the leadership of the private sector. New, well-paying joes will almost exclusively depend upon the ability and willingness of private entrepreneurs and institutions to invest in Massachusetts.

Everyone has a stake in the economy of Massachusetts--business, iabor, and government. Consequently, in the weeks and months ahead, we must progress from drelling on the syraptoms and causes of the state's economic probiems to coliaborative ventures to strengthen the foundation on which economic prosperity can be achieved in the future. 
This program is primarily the work of my Development Cabinet, consisting of Lieutenant Governor D'Heill, Secretaries Smith, Salvucci, iurphy, Flynn, and Sullivan, and State Planning Director Keefe, serving as Chaiman.

Many individuals outside state government have assisted the Deveiopment Cabinet in the revision of earlier. drafts of this program, including members of the Local Government Advisory Comittee, the Task Force on Capital Fomation, and meny proninent business and labor leaders.

Ėzause pollaies should always change with new information and better icess; I urge you to consider this a working document-a document that will assis: you in censidering the state's economic predicament and in partici02tis with us in init fatives to stimulate new esonomic vitality. Please

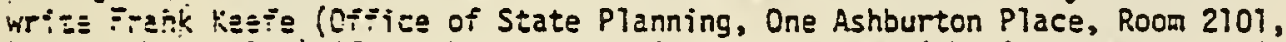
S2stef, iff 02103) it you have suggestions on how we might improve upon this F. eFisr:id thrugin an on-soing seriff of economic development conferences

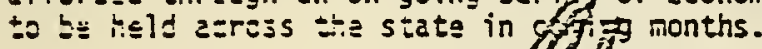

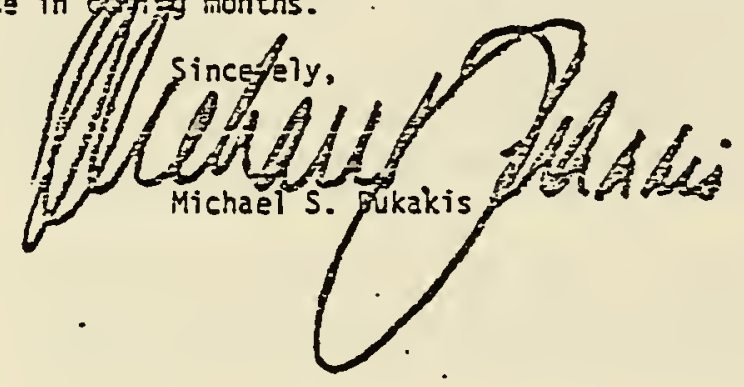


Priusties

Tre costs of doing business in Massachusetts linit the expansion of zin industries, particularly those in manufacturing wisich depend heavily a erergy or access to new materials. Nevertheless, aany other incustrias - Eptible witi and, in fact, often depend upon the special charactertes of our stete's economy and enviranment. The in-rigration or expansion F Hese fidustries often is linited by a particuler tax or regulation, or by =ayai?ajility of spacial hinds of labor or venture capital. These inwith growth poisntia? fal? into five categcries:

Thisse which raijta di-actiy to our technology base and to the ingrkets thoy seria such as computers, medical instrumentation, and soler enargy. The establishment of a loss carryFrore-d provisica in our corporate income tax can help to spein and retain irro:ative technology-based firms in Massachiserts. Such a crar.g would bring about symetry between the Massachus at:s tax eode and the tax codes of the Federali Government and neny other states. Service sector i.:ust-ies, such as trade, finance, insurama,
natical, edusat: hezdquerters in jarticular, which can be well-served in ass. by the oroxi-i $\because$ of many high-quality residential neightor $=$

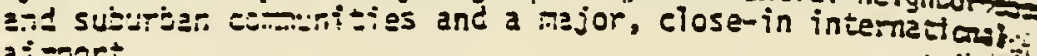
e? iport. $\therefore-\cdots$

$\therefore$ itural resourse-szsed industries such as the fishing and wood preduct indistries, which have access to the natural. ræsources upon which they depend end the markets they serre. inis weuid also inelude the tourist industry, which is deFen:ent on the preservation of our unique natural resoures. ent his toric sites. 
- Industries which are under-represented in New England, resulting in the import of goods and services which could be:= produced in Massachusetts. Among the industries with intorssubstitution potantial are a number of wood product, food:precessing, metal fabrication, and machinery production iridus Łries.

- Industries which can capitalize on available federal re-. saurces. These industries include:

- Pesearch and development, inciuding research on 21sernative enersy resources and medical research

- Heising, antzijing the use of MMFA and MHMFR to capi-. ta!iza sn z:ailable federa? rent and mortgage subsidies -

- Pollution costrol equipment.

These E:Forss to rea!i:e the growth potential of industries which are compatible with zur state's ecoromy and environmant provide an essential co-

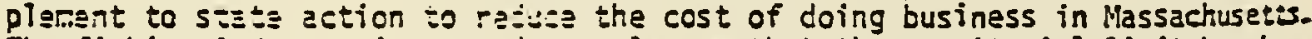

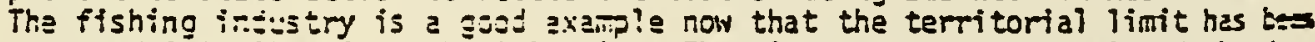

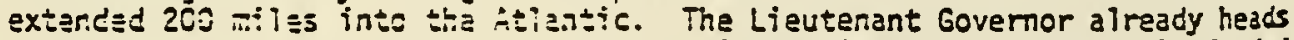
a "200 Ey. the Kew E.

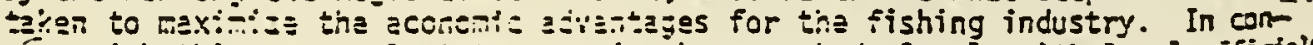
7 iftitis, saveral state a

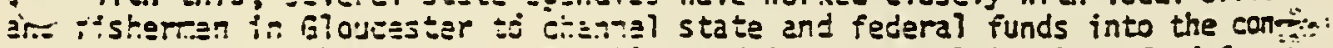

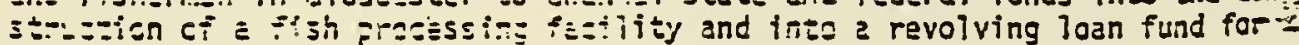

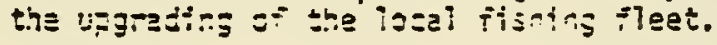




\section{INOUSTRIES}

PRIORITY: To Encourace the Maximum Frouth of Mew Jobs in Those Industri? which are Best Able to Take Advantare of "lassachusetts Ecsnomic Assets

All of the initiatives advanced in this orogram to constrain the costs and increase the convenience of doing business in Hassachusetts will serve to encourace the creation of new jobs, especiaily in those industries that have natural qrexth potential. State goverment cannot create these ne jobs diraetly. Instead, it must proceed by fostering an imoroved seneral climate for operating bus inesses and undertaking inles:-an:s. More directly, the state can attract new corporz:a haadquarters and encourage the expansion of technologr and ratura? resource-based industries, as well as the exp!oitation of import-substitution opportunities, by pursuino th.e steps set forth below.

NEXT STEYS: A. Enact a loss carry-forward tax provision for all new and expanding companies in Massachusetts.

3. Imolement the Capital Formation Task Force financing mechansins that receive Gubernaturial and legislative aporoval.

C. Evaluate the cost-effectiveress of a variety of tax incentive proposals for such new grovth potential industries as solar energy and fishino.

KD. Continue the work of the "2nn-inile 'Vorth Froup" in assessing specific ways to expand the Massachusetts fishing industry.

E. Improve the capacity of state governaent to identify industrial development ouportunities and to orovide information and assistance to prosoective entrepreneurs and investors, with soecific regard to taking advantaqe of import-substitution opportunities. State covernment will work with private sector and acedemic economists to identify those products that are heavily inoorted to Massachusetts and to assess the opoortunities for local production of these products and the potential consumer savings resulting from such local production. Host imortant, state government will distribute this information and provide follow-up assistence to those who might want to take advantage of these import-substitution opportunities. 
Fisting is the oldest Industry in Massachusetts and has played a pronireat -ole in New Englant's history. Unforturatel $;$, as a Iesult of improper mangeEant, an excess of foreign 5 ish 28 off the Geosges $32 n k$, and the exploynent of destructive sishing practices, the industzy is now on the briak of destruction If.

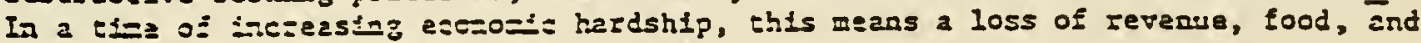

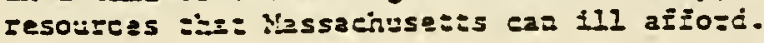

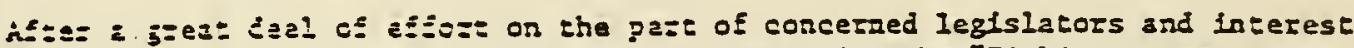

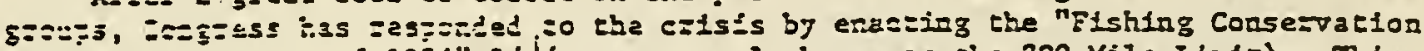
a.d

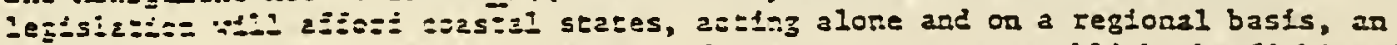

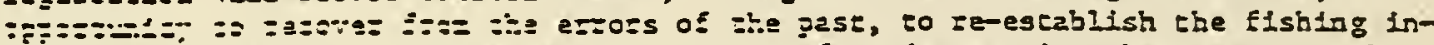

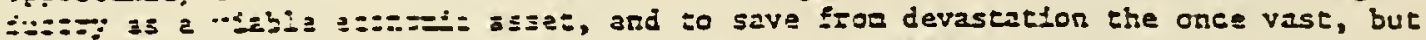
"C:

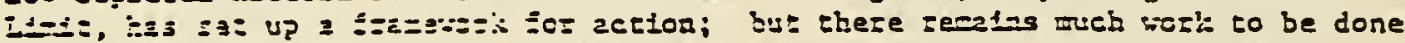

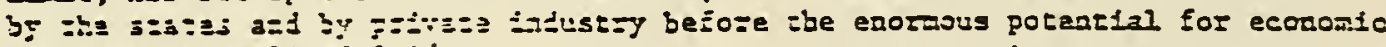

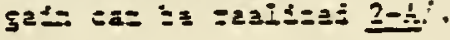

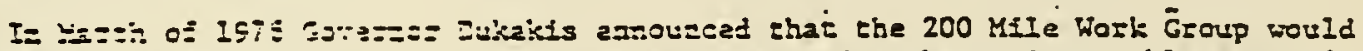

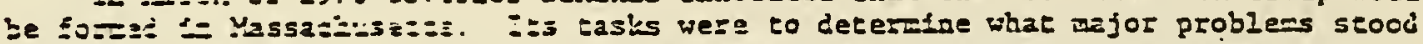

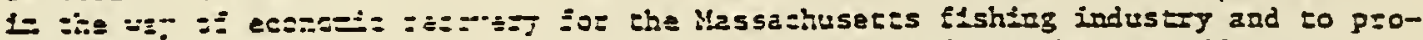

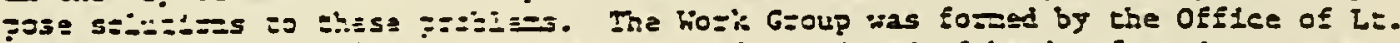

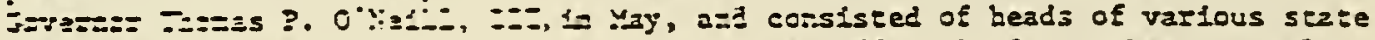

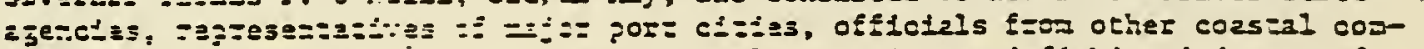

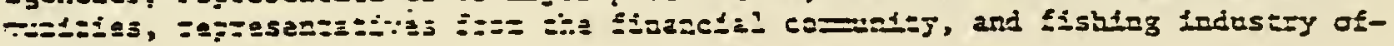
1cí2is.

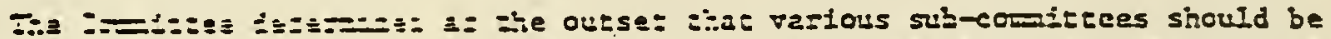

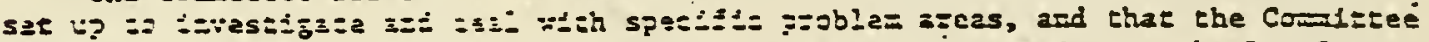

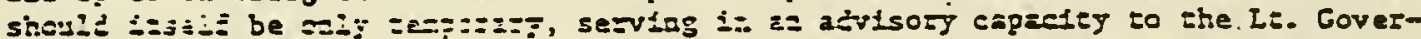

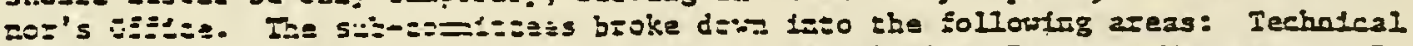

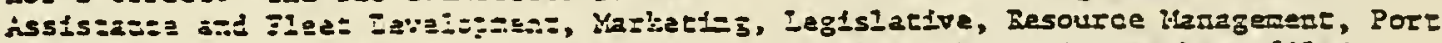

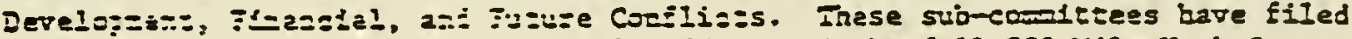

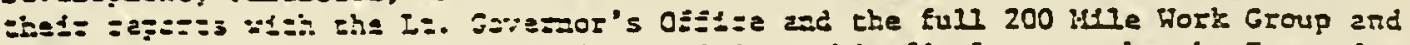

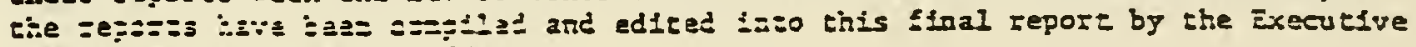

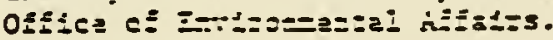

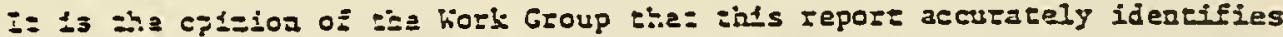

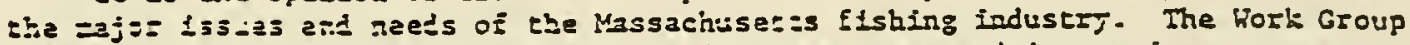

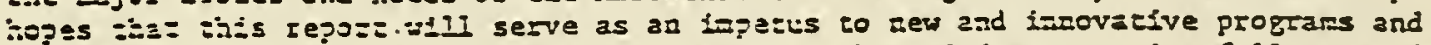

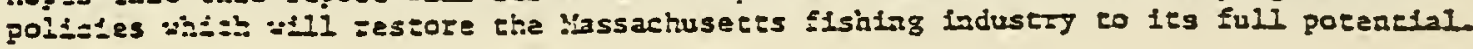




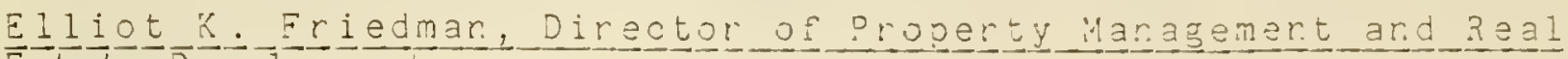
Estate Deve10pment

Mr. Friedmar is resporsible for the directior. of Massport's special developmert projects. He was previously tha ?roject Director for the Bostor Redevelopmert Autiority's South Cove Urpar. Rerewal Project, and Director of Developinert for tne Bostor. University Admiristration.

Mr. Eriedmar has nany years of planning and developmert exprierce. He recieved a Master's Degree ir Public Administration from Northeastern University and an A. 3 . from the University of Perrsylvaria.

\section{Qobert S. Parks, Prooerty Manager}

Mr. Parks is responsible for the inairtenarce and marazenent of the Fish Pier area. Prior to working at Massport Mr. Parks was owner and inanager of $\exists$ business responsible for the sales and service of oil and gasolire equipment; he is irvolved in numerous community organizations ard is currently president of Roxbury terarts of Harvard, Director of the 30 ard of Mission Park Corporation, Vice President of the Consumer Advisory Courcil, Presidert of Mission iill Health Movements, member of the Area Plarring Action Courcil Parker Hill/Eenway area, nember of the Board of Directors of Parker Hill Medical Certer and of tine Harvard Community Health Plar. In the past he has been a Trustee of the Affiliated Hospital Center, menber of the Board of the Health Planring Council of Greater Boston, Chairnan of the Policy Board of the Mission Hill Outreach for tise Harvard Community Health Plar and fourder and menber of the Mission Hill Planring Commission.

Mr. Parks has had a great deal experience ir entrepreneurial managemert ard policy formation. He has a 3.S. ir Business Administration from Bostor. Collage.

Joseph J. Rarda11, Project Ergireer

Mr. Rardall is resporsible for review of the Architectural/Engineerirg work for the project and for technical advice to Massport's Department of Property Yanagement and Real Estate Developmert.

Following Mr. Randall's graduation from college he held many positions ir Civil and Architectural Engireering; begirning as ar. Engireer ard up to Presidert of an Engineerirg Consulting firm. te has worked or $\exists$ variety of projects inciuding jridges, commercial and industrial buildings ard building modifications. His experience in the public sector includes work as a Siructural 

Mr. Randall attended Northeastern University and has a B.S. in Civil Engineering. He is currently a Registered Professional Engineer in Massachusetts, Rhode Island, and Maine, and is a member of the American Society of Civil Engineers.

\section{David B. Weiner, Director of Engineering}

As Director of Engineering, Mr. Weiner oversees all construction projects in the Authority.

Prior to coming to the Port Authority, Mr. Weiner worked at the Boston Redevelopment Authority, for fifteen years as project engineer, assistant chief engineer, and project director. He has worked on Government Center, the Boston Waterfront, the Charlestown Navy Yard and Copley Square. of particular note here is the waterfront project which involved the rehabilitation of existing historical buildings; the Faneuil Hall Markets, the Mercantile Wharf Building, and the piers along Atlantic Avenue. He has also worked at William A. Fisher Co. and at Edwards and Kelcey.

Mr. Weiner holds a B.S. in Civil Engineering from Northeastern University and is a Registered Professional Engineer in Massachusetts. 


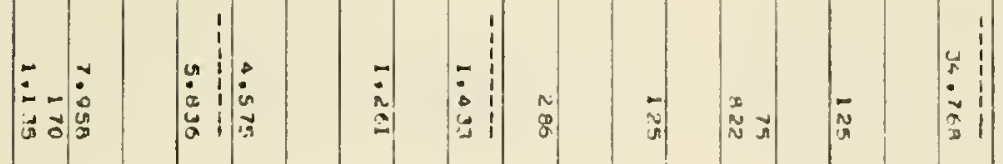

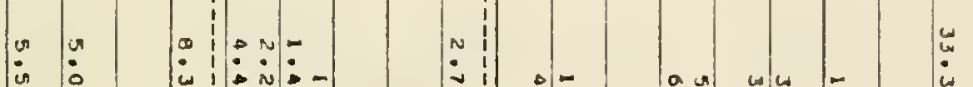

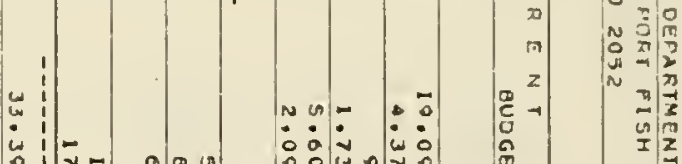

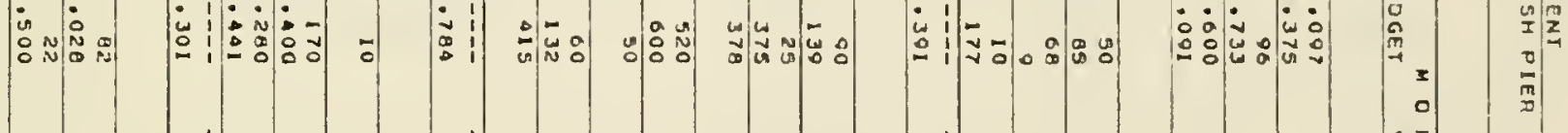

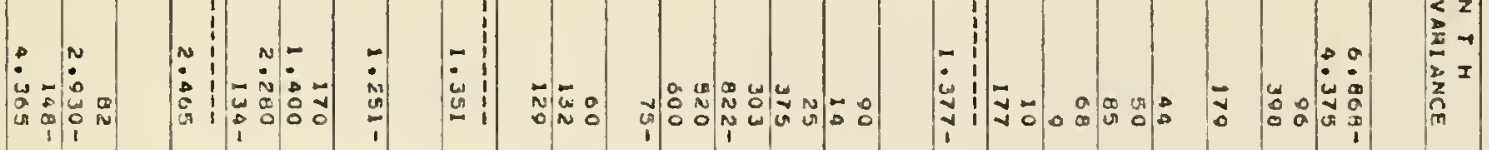

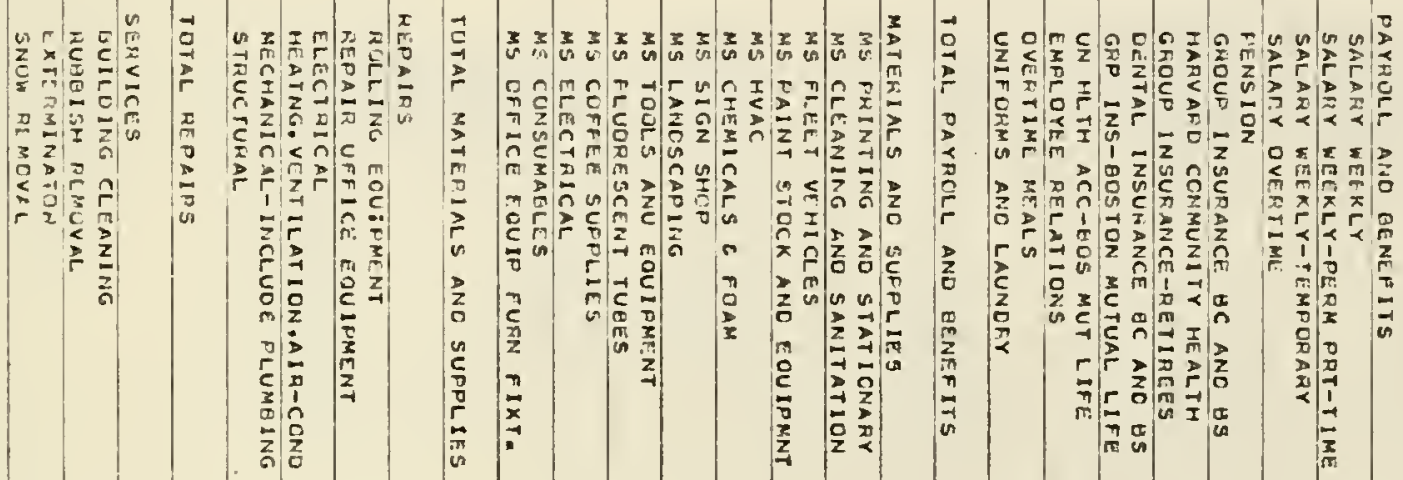

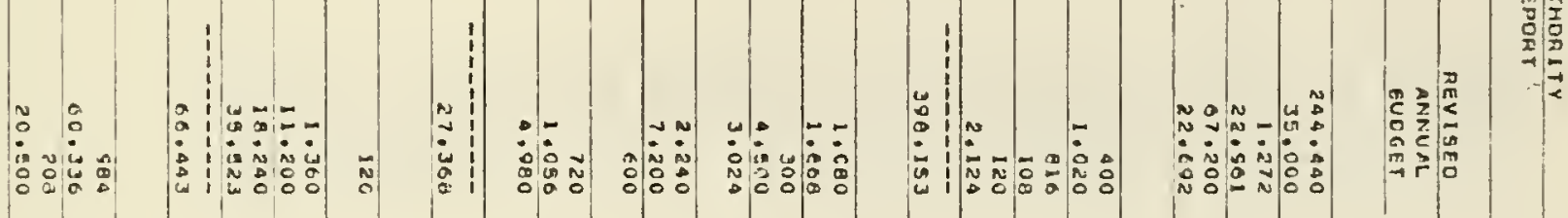

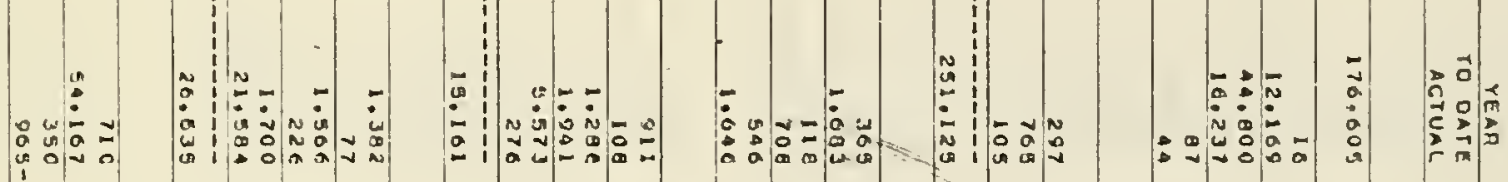

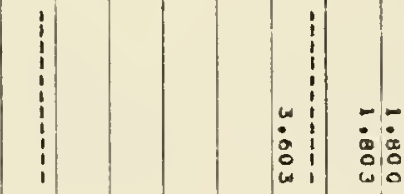

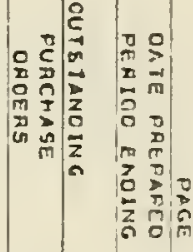

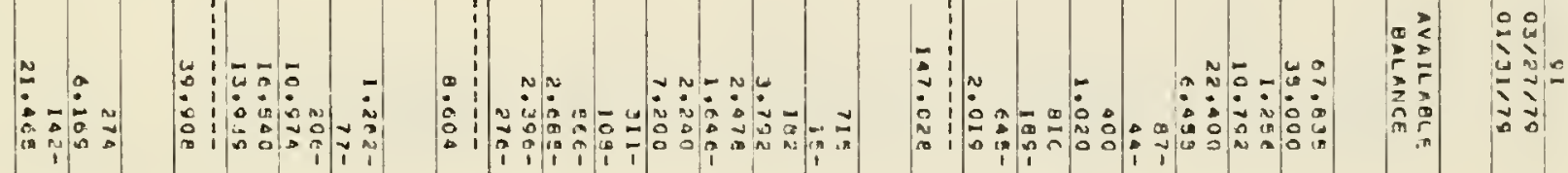




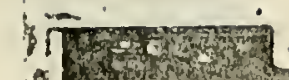

* o 6 -

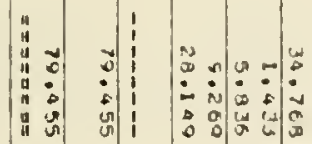

Z

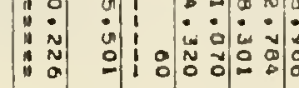

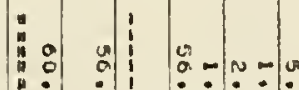

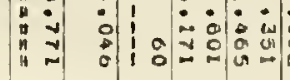

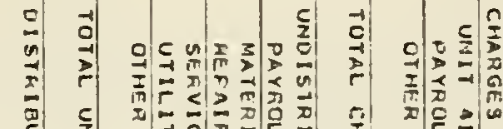

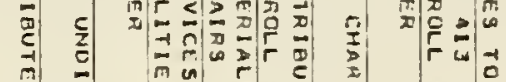

贻

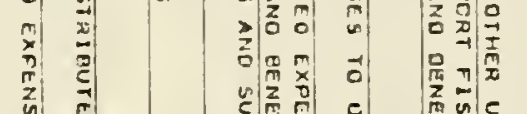

(n)

$(4)$

ํ.

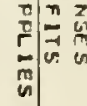

곡

$\frac{c}{\mathfrak{s}}$

:

a

垈

:

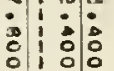

(

2

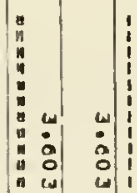

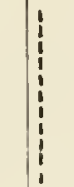

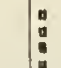

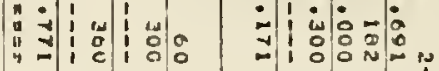

:

$=$

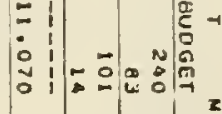

$\bar{a}$

[]

in

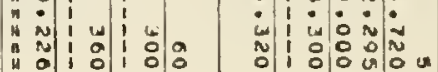

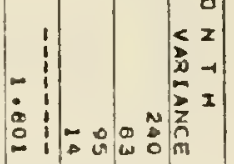

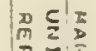

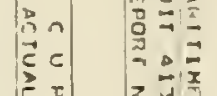

$z=\frac{\pi}{4}$

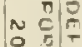

$\operatorname{lic}_{0 \rightarrow 2}$

证

$2: \frac{2}{4}$

i 


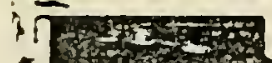

c

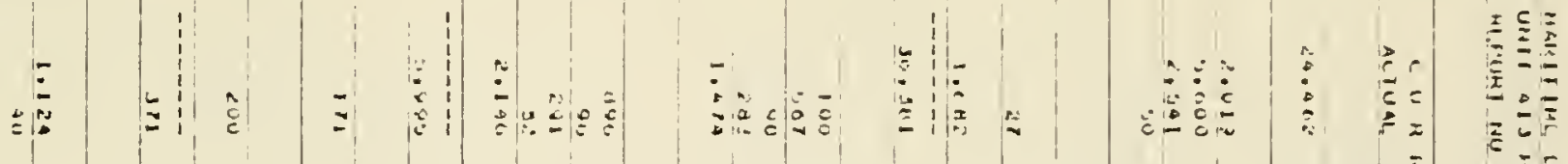

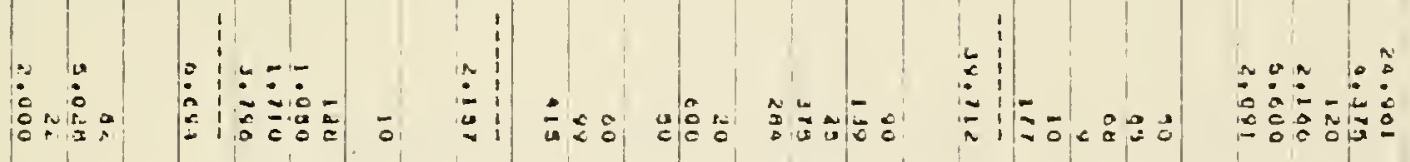

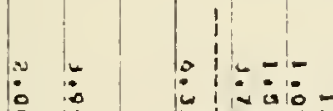

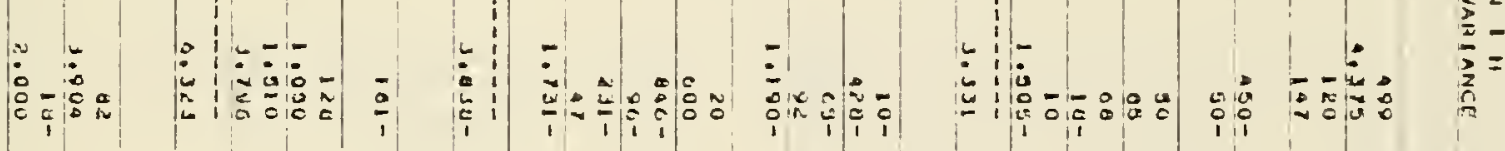

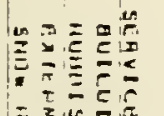

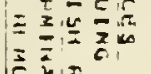

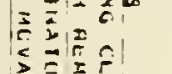

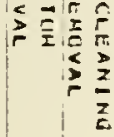
है:

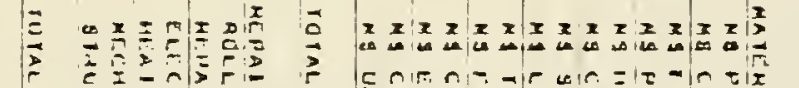

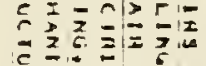

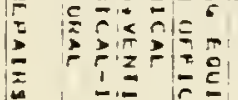

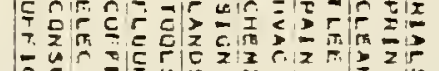

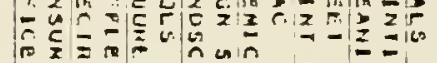

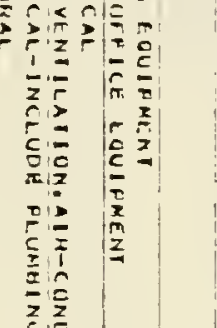

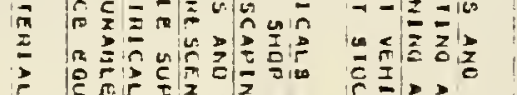

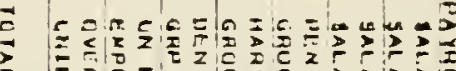

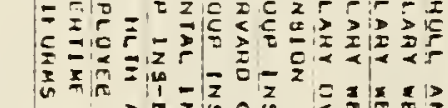

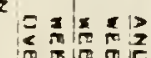

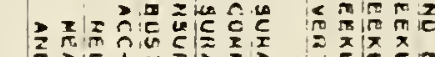

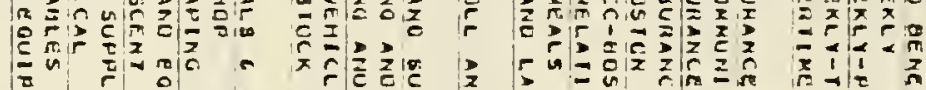

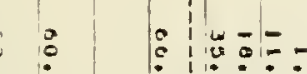

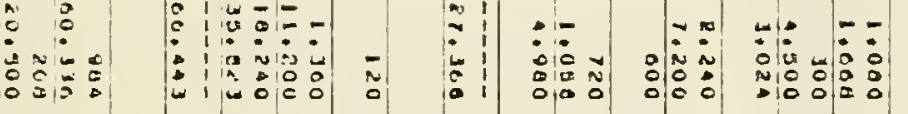

(a)

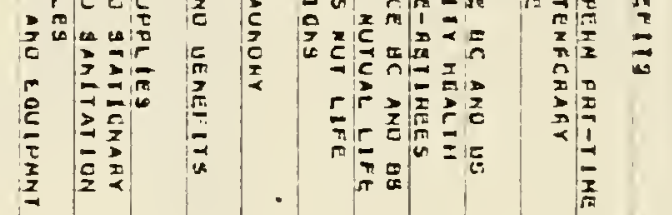

舟

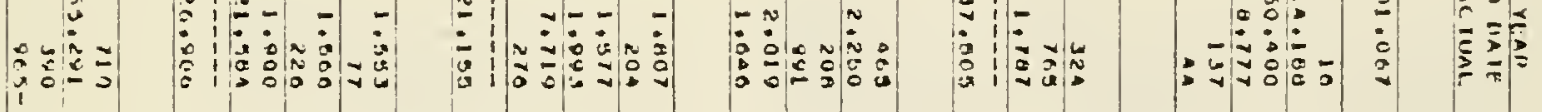
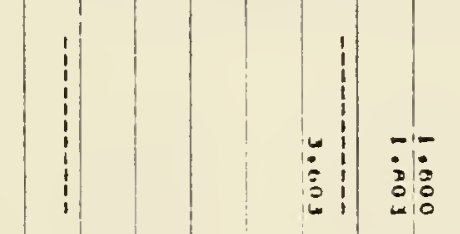

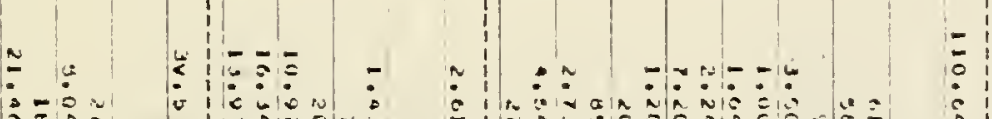

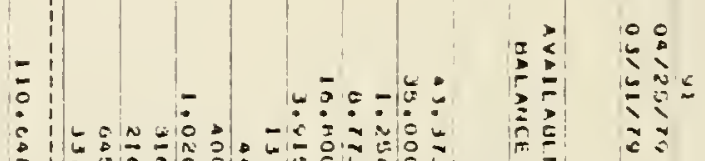

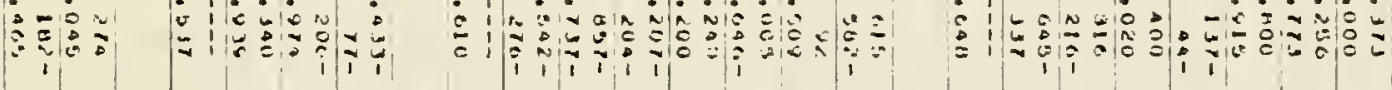




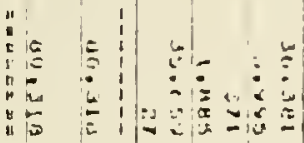

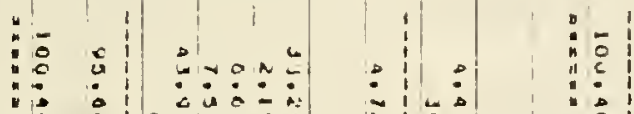

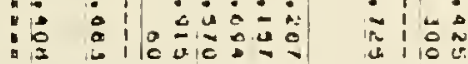

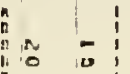

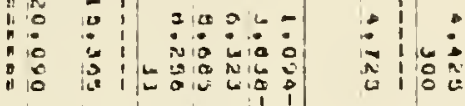

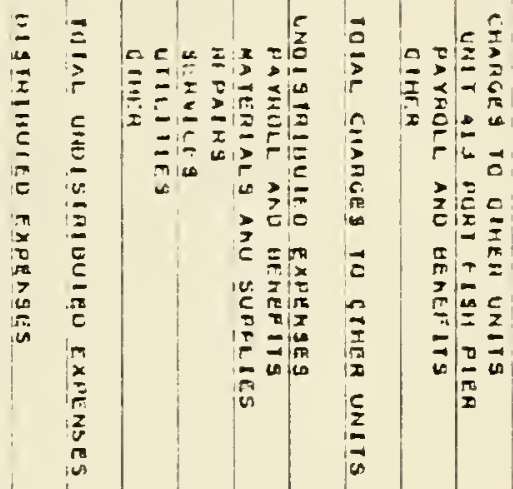

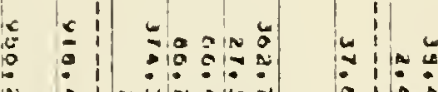
焉

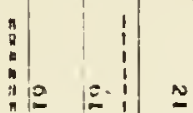

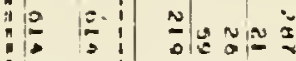

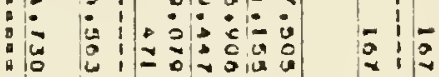

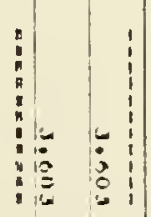

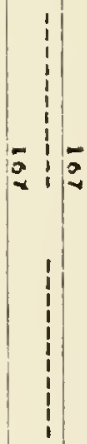

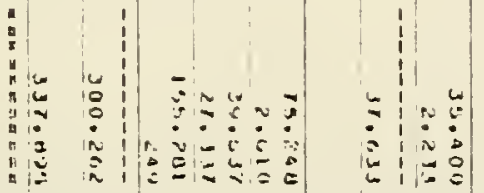

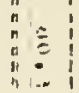

$:$

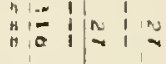

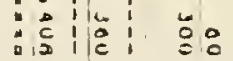

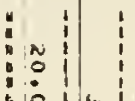

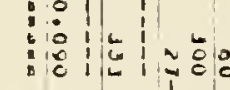

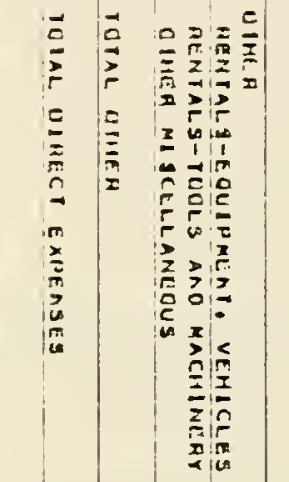

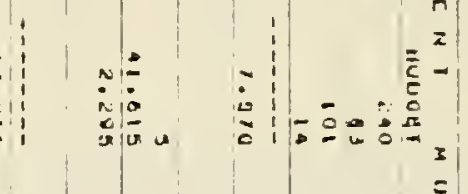

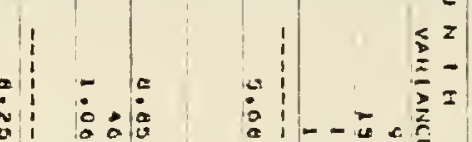

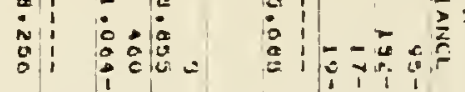

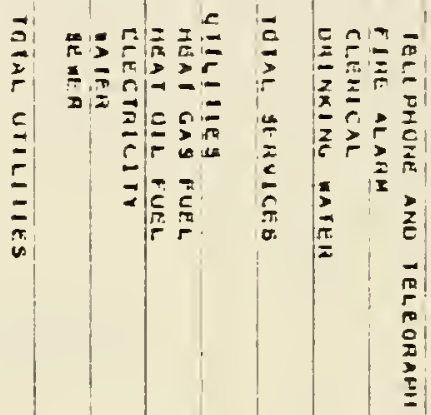

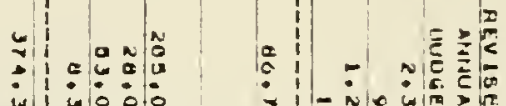

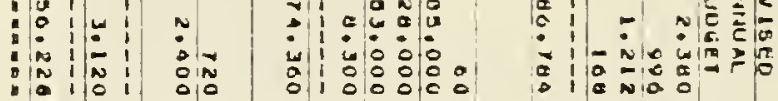

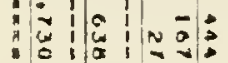

:

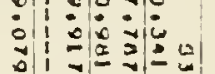

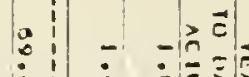

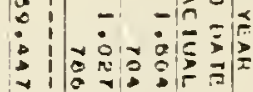

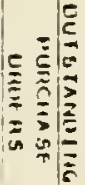

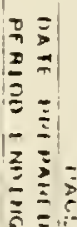

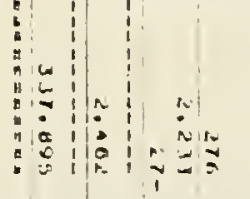

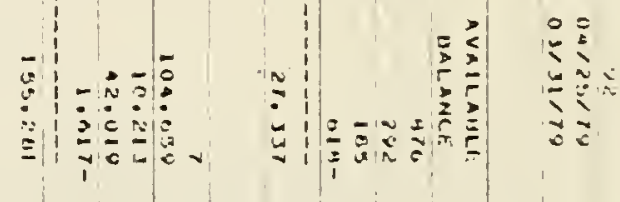
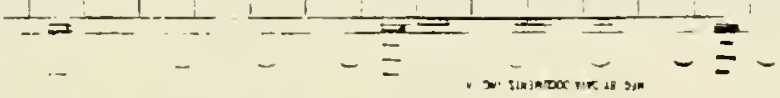

- 


\section{ENVIRONMENTAL INFORMATION}

Item lo. Has a Federal, State, or Local Environmental Impact Statement or Analysis been prepared for this project?
$\square$ Yes
[xo
Copy attached as EXHIBIT II-A-8(1)(a)

b. If "No," provide the information requested in Instructions as EXIIIBIT II-A-8(1)(b)

[X] EXHIBIT II-A-8(I)(b) altached

Item 2. The State Historic Preservation Officer (SHPO) has been provided a detailed project description and has been requested to submit comments to the appropriate EDA Regional Office. $X$ Yes $\square$ No

Date description submitted to SHPO April 6, 1978

Item 3. Are any of the following land uses or environmental resources either to be affected by the proposal or located within or adjacent to the project site(s)? Check appropriate box for every item of the following checklist.

YES NO UNKNOWN

1. Industrial

2. Commercial........

3. Residential........ $\square$ $\mathrm{X}$

4. Agricultural ....... $[\square] \mathrm{X}$

5. Grazing.......... $\square$ X

6. Mining, Quarrying .... $\square \square$

7. Forests

8. Recreational

9. Transportation........

10. Parks

11. Hospitals

12. Schools

13. Open spaces

14. Aquifer Recharge

Area

15. Steep Slopes........

16. Wildlife Refuge.......

17. Shoreline

18. Beaches............
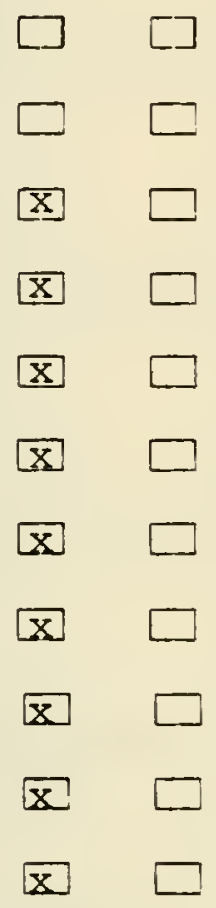

$\mathrm{x}$

$\mathbf{x}$
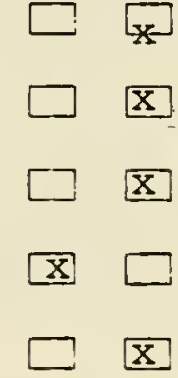

19. Dunes ..............

20. Estuary .............

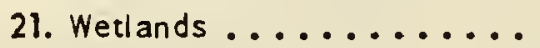

22. Floodplain ...........

23. Wilderness /designated or proposed under the Wilderness $A c t$ ).

24. Wild or scenic river (proprosed or designated under the Wild and Scenic Rivers Act)......

\section{YES NO UNKNOWN}

\section{$\square$}

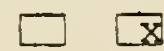

$\square \quad x$
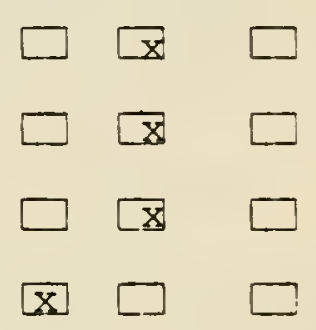
Federal Agencies are required by law to independently assess the expected environmental impacts associated with proposed Federal actions. It is extremely important that the information provided be in sufficient detail to permit EDA to perform its evaluation. The information requested must be submitted with the preapplication. Failure to provide sufficient data will delay agency review and a decision to formally authorize an application.

This information request is designed to obtain an understanding of the area's present environmental condition and the project's elements that will affect the environment. Should you believe that an item does not apply to the project, consult with EDA's Economic Development Representative (EDR) before responding. In all cases when it is believed that an item is not applicable, explain the reasons for this belief.

It is important to understand the comprehensive nature of the information requested. Information must be provided for a) the site(s) where the project facilities will be constructed and the surrounding areas to be affected by its operation and b) the areas affected by any primary beneficiaries of the project. The amount of detail should be commensurate with the complexity and size of the project, and the magnitude of the expected impact. Some examples:

A small community center project may not require detailed information on air emissions, meteorological conditions and solid waste management.

A water resource or industrial development project will require detailed information.

Item 1a - Compare the Environmental Impact Statement or Analysis with the information requested in the instructions for ltem ib below to be sure that every point is covered. Reference the location of that information in the Statement for each item covered. Correct any deficiencies/omissions in the information supplied and attach to the document.

Item Ib - Provide responses to the following items in the order listed and attach as EXHIBIT II-A-8(1)(b):

\section{(1) Primary beneflciarles}

Identify any existing businesses or major developments that will benefit from the proposal, and those which will expand or locate in the area because of the project. These businesses or major developments hereafter will be referred to as primary beneficiaries.

\section{(2) Area Descriptlon}

(a) Describe the size, terrain, and present land uses as well as the adjacent land uses of the areas to be affected. These areas include the site(s) of construction activities, adjacent areas, and areas affected by the primary beneficiaries.

(b) For each box checked "Yes" in item 3, describe the nature of the effect on the resource. If one or more of boxes 17 through 21 is checked "Yes" or "Unknown." contact the EDR for instructions relating to the requirements imposed by the Floodplain Management and Wetland Protection Executive Orders.

(c) Attach as Exhibit II-A-8(1)(b)(2)(c) the following: 1) a U.S. Geological Survey "15 minute" ("7-1/2 minute" if available) topographic map which clearly delineates the area and the location of the project elements; 2 ) the Department of Housing and Urban Development's floodplain $\mathrm{map}(\mathrm{s})$ for the project area; 3 ) site photos; and 4) if available, an aerial photograph of the site. If a floodplain map is not available, contact the EDR for additional instructions relating to the requirements imposed by the Floodplain Management Executive Order.
(3) Alr Quality

(a) Provide available air quality data from the monitg station(s) either within the project area or, exist, nearest the project area.

(b) Indicate the types and quantities of air emissions be produced by the project facilities and its prim beneficiaries. If odors will occur, indicate who be affected.

(c) Indicate if topographical or meteorological conditio hinder the dispersal of air emissions.

(d) Indicate the measures to be taken to control emissions.

(4) Waler Quality

(a) Provide available data on the water quality of sur or underground water in or near the project area.

(b) Indicate the source, quality, and available supply raw water and the amount of water which the projec designed to utilize.

(c) Describe all of the effluents or discharges associ with the project facilities and its primary beneficiar Indicate the expected composition and quantities these discharges prior to any treatment processes they undergo and also prior to their release into environment.

(d) Describe any treatment systems which will be us for these effluents and indicate their capacities their adequacy in terms of the degree and type of $t r$ ment provided. Indicate all discharges which will no treated. Describe the receiving waters and their 4 (e.g., recreational) for any sources of treated untreated discharge.

(e) If the treatment systems are or will be inadequ overloaded, describe the steps being taken for nec ary improvements and their completion dates.

(f) Describe how surface runoff will be handled discussed in (3) above.

(5) Solid Waste Management

(a) Indicate the types and quantities of solid wastes $t$ produced by the project facilities and its pri beneficiaries.

(b) Describe the methods for disposing of these : wastes plus the useful life of such methods.

(c) Indicate if recycling or resource recovery programs or will be used.

\section{(6) Transportatlon}

(a) Briefly describe the available transportation facil serving the project area.

(b) Describe any new transportation patterns which arise because of the project.

(c) Indicate if any land uses, such as residential, hospi schools or recreational, will be affected by these patterns.

(d) Indicate if any existing capacities of these transp tion facilities will be exceeded. If so, indicate increased loads which the project will place upon t facilities, particularly in terms of car and truck tra 


\section{INSTRUCTIONS}

(7) Noise

(a) Indicate the major source of noise associated with the project facilities and its primary beneficiaries.

(b) Indicate the land uses to be affected by this noise.

\section{(8) Historic/Archeologlcal Properties}

(a) Identify any known historic/archeological resources within the project area that are either listed on the National Register of Historic Places or considered to be of local and state significance and perhaps eligible for listing in the National Register.

(b) Attach as EXHIBIT [I-A-8b(1)(b)(8)(b) any historical/ archeological survey that has been conducted for the project area.

\section{(9) Wlidllfe and Endangered Specles}

(a) Identify wildlife resources located in the project area or $i$ ts immediate vicinity.

(b) Indicate whether any endangered or threatened species have been identified in the project area or its immediate vicinity.

(10) Energy

(a) Describe the energy supplies available to the project facilities and the primary beneficiaries.

(b) Indicate what portion of the remaining capacities of these supplies will be utilized.

\section{(11) Coostruction}

Describe the methods which will be employed to reduce adverse impacts from construction, such as noise, soil erosion and siltation.

\section{(12) Toxic Substances}

(a) Describe any coxic, hazardous, or radioactive substances which will be utilized or produced by the project facilities and its primary beneficiaries.

(b) Describe the manner in which these substances will be stored, used, and disposed.

\section{(13) Public Reaction}

(a) Describe any objections which have been made to the project.

(b) If a public hearing has been held, attach a copy of the transcript as EXHIBIT Il-A-8(1)(b)(13)(b). If not, certify that a hearing was not held

(c) Indicate any other evidence of the community's awareness of the project such as through newspaper articles or public notification.

\section{(14) Aiternatives to the Proposed Praject}

Provide a description of any of the following types of alternatives which were considered:

(a) Alternative locations.

(b) Alternative designs.

(c) Alternative projects having similar benefits.

\section{(15) Mltigatlon Measures}

Describe any measures which will be taken to avoid or mitigate any adverse environmental impacts associated with the project.

\section{(16) Permlts}

(a) Identify any permits of an environmental nature which are needed for the project.

(b) Indicate the status of obtaining each such permit and attach as EXHIBIT [I-A-8(I)(b)(16)(b) any that have been received.

Item 2 - Applicants are required to provide the State Historic Preservation Officer (SHPO) with a) a narrative description of the project's elements and its location, b) a map of the area surrounding the project which identifies the project site, adjacent streets and other identifiable objects, c) line drawings or sketches of the project and d) photographs of the affected properties if building demolition or renovation is involved. This material must be submitted to the SHPO no later than the date of the preapplication. Additionally, the SHPO must be requested to submit comments on the proposed project to the appropriate EDA Regional Office.

Item 3 - Self-explanatory.

Item 4 - Self-explanatory. 


\section{SUMMARY}

Institution of the 200-mile limit has provided a major opportunity for the U.S. fishing industry - so critically Impacted by subsidized foreign competition in the past - by protecting U.S. fishermen's rights to fish caught off the nation's shores.

Between 1960 and 1965 , more than 100 million pounds of fish were landed at the Boston Fish Pier which served as the ceater of a flourisbing industry. On Georges Bank, $88 \%$ of the fish caught in 1960 were brought in by U.S. fishermen. 17 years later, bowever, this percentage had dropped to 10. Competition by subsidized foreign fleet decimated the formerly fruitful tadustry.

The Boston Fish Pier, located at the center of New. England's regional truck routes and only minutes from logan Alrport, is the logical center for processing the increased U.S. catches expected from Georges Bank. As the quantity of frest flsh shipped by air grows, this logistical advantage wIl become even more important.

To accommodate the needs of modern processing plants, the Boston Fish Pier must undergo rebabilitation. This redevelopmeat wil bring more than 825 new jobs to an laner-ctty area suffering from bigh blue-collar unemployment and an additional 2060 new jobs to tbe region, due to a multiplier effect.

Private businesses are ready to invest almost two 
million dollars immediately, and substantially more in tie future, in new capital equipment at the pier as soon as rehabilitation is completed. The momentum for growth exists. The industry is simply awaiting a catalyst. Economic Development Administration and Masport funding of Boston Fish Pier rehabilitation would provide the spark needed to begin fundamental revitalization of the Boston fishing industry. 
ENVIRONMENTAL ASSESSMENT

Exhibit II $-A-8(1)(b)$

(1) Primary Beneficiaries The planned project is a rehabilitation of four existing structures and a pier for use by the fishing industry for the landing, unloading processing and transporting of fish. The primary beneficiaries therefore will be the fishermen, fish processors and brokers in the Boston area and the New England region.

Also, because of Boston's importance in the New England region as a transportation center, many New England fish firms have expressed an interest in opening a sales and distribution center in Boston, in addition to their stores/plants in other ports. The Port Authority has had three formal requests and numerous informal requests for space on the Boston Fish Pier. [see attachment 1, Exhibit IV $1-a]$

(2a) Area Description The Fish Pier (Pier No.6) is located on Northern Avenue in Boston south of the Fort Point Channel. To the south lies the residential community which stretches from Dorchester Avenue in the west to the Inner Harbor on the east and south. 
The pier was built on landfill, at the beginning of this century. The area itself is one of Boston's largest industrial sections. Predominant uses in the area are transportation related, as the area offers good access to the Central Artery and downtown Boston via Summer Street and Northern Avenue.

Waterfront and marine industrial and commercial uses, fish processing, seafood packaging and distribution, boat repairing, and navigation equipment sales, related office uses, freight depots and seafood resturants exist on both sides of Northern Avenue. There is a large, but now predominantly inactive railroad switch yard which is owned by Massport and used for new car storage, parking for the convention center, and other open area activities.

Northern Avenue is a wide (equivalant to eight operating lanes) thoroughfare that allows for adequate traffic flow.

The primary zoned land use in the area is waterfront industrial and general manufacturing. Waterfront industrial as a zoning classification also allows for office uses and wholesale business and storage.

Population of South Boston totals 38,488 (City of Boston 641,071). The Fort Point Channel share of this population is negligible (see Table 1 and Map of area).

2b1 Industrial uses: The fishing industry is the primary user of land in the immediate area, and is centered on the Boston Fish Pier and in several buildings near the pier 
[Buildings 4 and 5, for example, are also owned by Massport and used by fish processors and other fishing support industries]. Over the years, the Fish Pier has fallen into a state of disrepair. The proposed project is a repair, rehabilitation and renovation effort to assist in the revitalization of the fishing industry.

2b2 Commercial uses in the area consist of a few retail stores and restuarants. The present establishments exist in the area because of the fishing industry. This rehabilitation, since it will enhance the Boston Fish Pier will improve the environment for these commercial establishments.

2.b17 This project is a rehabilitation of an existing shoreside facility. The shoreline will not be altered in any way.

2b22 Flood plain: The Fish Pier lies within the special Flood Hazard Area map by the Flood Insurance Administration for Boston. (Community 250-286)

Massport is in the process of filing for Flood Insurance for the Fish Pier buildings, including numbers 1, 2 and 3 and the Power Plant. 
2 b29 see ( 5 ) below

(3) Air Quality

Existing Air Quality is measured by the Commonwealth of Massachusetts Department of Environmental Quality Engineering in two locations, Kenmore Square and the East Boston Callahan Tunnel. (see attached) Neither of these sites is near the project site.

It is very unlikely that the air quality background concentrations in the vicinity of the Fish Pier project are as high as shown at the monitoring locations due to greater amounts of open space available at the Fish Pier, the influence of sea breezes and the presence of substantially less traffic at the Fish Pier than at Kenmore Square or the East Boston Callahan Tunnel. Hence monitoring sites shown worst case conditions. Furthermore of the two pollutants that could be expected to increase very slightly from the project area, carbon monoxide and photo chemical oxidants (ozone), the former has been decreasing throughout the region and the latter cannot be considered a local pollutant; that is, the ozone present at the Fish Pier is not formed at the site. The hydrocarbons emmitted will contribute in a small degree to the ozone formation that will be measured elsewhere. Increase in nitrogen dioxides will be imperceptible. 
The small amounts of dust generated during the renovation period should cause insignificant air pollution problems in that area.

The project is expected to have little adverse impact on air quality. Due to increased use of freezer storage, truck traffic will not increase over present levels even if the fish volume handled does increase. (that is, the trucks will operate at higher load factors). Hence the air pollutants from trucks will not increase.

The air pollutants from increased automotive travel will be minimal, and will not degrade the air quality. (See item 6)

The fish processing that will take place on the renovated pier will not emit additional air emissions or odors than are now occuring. In fact, the odors should be substantially reduced as the processing techniques are improved.

(4) Water Quality

The Fish Pier receives its water from the City of Boston. Small quantities are used in fish processing. The proposed project will increase the amounts of process water used, but the increase will be minimal.

The Fish Pier is already tied in with the sewer system of the City of Boston. The additional sewage emanating from increased Fish Pier activity will not be significant enough to have an impact on this system. 
Sewer lines will be redone and adequate effluent controls will be installed to block the entry of fish scales and other wastes into the waterways. Hence, the rehabilitation of the Fish Pier will improve both sanitary conditions and water quality. The Commonwealth of Massachusetts, Division of Water Pollution Control has been informed of the rehabilitation of the Boston Fish Pier, when engineering designs of sewer lines and efficient controls are prepared the designs will be submitted to the Division of Water Pollution Control.

For a description of existing harbor water quality within the vicinity of the Fish Pier see the attached maps. As can be seen, water quality in this particular area of Boston Harbor is quite poor. Although modernization of the Fish Pier would not add to the already high levels of water pollution, any water quality improvement brought about by the project would be imperceptible.

\section{(5) Solid Waste}

The solid waste from the renovation project will be salvaged where possible, and where not possible, it will be carted away to a suitable disposal site approved by the state and municipal governments. The on-going refuse from the operation is and will be removed by regular trash collection and transported to a suitable and approved disposal site. Gurry from the fish processing is transported and sold for cat food. 


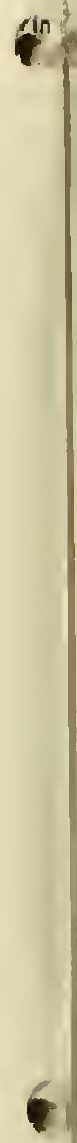


The Northern Avenue area, because of its proximity to downtown Boston, has many modes of transportation available to it.

Most transporting is now done by truck down Northern Avenue. Truck and automobile traffic on Northern Avenue is now around $14-15,000$ daily trips. Total rehabilitation of (including Phases $I$ and II) the pier will result in the addition of 200 more vehicles (for employees) in 1982 plus additional business travel which Northern Avenue can easily handle. There will also be an addition of $100-200$ employees along Northern Avenue (other than at the Fish Pier) as a result of the revitalization project. In order to expedite traffic flows in the area parking for Fish Pier employees, customers, and clients will be relocated to Commonwealth Pier and/or Commonwealth Flats.

A parking plan for the Fish Pier area is in the process of being developed and will be implemented in the near future by Massport. Crucial elements of the plan include installation of meters for cars parked on Northern Avenue and fencing around a lot in Commonwealth Flats.

\section{(7) Noise}

Additional noise generated during the renovation will be minimal. Noise generated by truck and automobile traffic, which exists notwithstanding reconstruction on the Fish Pier and which will continue throughout reconstruction, is greater than the noise anticipated to be generated by the 
construction. Also, the additional noise generated by new traffic after renovation will be insignificant.

Adjacent land uses will not be impacted by any noise generated by construction. As mentioned elsewhere land uses in the area are predominantly industrial and commercial, including warehousing, distribution and institutional. The nearest residential area is practically a mile away from the Fish Pier.

\section{Other Environmental Impacts}

There are no glare problems anticipated either during the renovation state or resulting from the ongoing operation.

There will be no unusual vibrations generated during the new operations at the Fish Pier. The vibrational effects during the renovation period will be minimal and sporadic.

There will be a major change in the visual appearance of the Fish Pier, as it changes from a dilapidated to a modern commercial structure.

(8) Historical/Archaeological Preservation

The Fish Pier is built on land created by a land fill project and hence has no archaelogical or historical significance. Northern Avenue is a fully commercially developed area with no noteworthy historical sites nearby. The environmental assessment done by Massport to comply with the Massachusetts Environmental Policy Act was shared with 
the State's Historical Commission. The Commission supported the Fish Pier renovation project.

(9) Natural and Recreational Effects

The Fish Pier is located in a commercially developed area. Its renovation, therefore, will have no effect on scenic or recreational areas, beaches, wetlands, or any wildlife. Since the current structure is dilapidated, its renovation will be an aesthetic benefit for the whole area.

(10) Energy

electricity - purchased from local utility, future plans will not alter this service.

heat - generated from high pressure steam-generating boilers. Boilers are filled with No. $6 \times 1 / 2 \%$ sulphur fuel oil. Total concept for the renovation of the Fish Pier includes replacement of these boilers with a low pressure steam system or indivudal heating units.

gas - supplied directly form local utilties, as required by tenants. No change expected in the future.

\section{(11) Construction}

For information on mitigation of noise generated by construction see (7) above.

Since this project is a rehabilitation of existing structures in a well developed site and area, soil erosion and siltation are not expected. 


\section{(12) Toxic substances}

Radioactive substances - none of the present or proposed activities at the Fish Pier will result in radiation emissions.

No toxic or hazardous substances will be produced by the Fish Pier or by the Fish Pier processors.

\section{(13) Public Reaction}

(a) No objections have been made to the project.

(b) Massport and Mintz Associates have been holding Program Committee meetings approximately monthly to discuss various aspects of the rehabilitation. Notes on these meetings are included as Exhibit II-A-8(1)(b)(13)(b)

(c) See Exhibit II $-A-8(1)(b)(13)(c)$

(14) Alternatives to the Proposed Project

(a) Alternative Locations

The fishing industry has been centered at Pier No. 6 in South Boston since 1914. Prior to 1914 fishing vessels landed at $T$ Whar $f$ in Boston. The present location suits the fishing industry well. The fresh fish industry must be located near the water so vessels can be unloaded. The pier's proximity to downtown facilities provides access to major interstate transportation networks, as well as to local city outlets. Relocation of the facility elsewhere in the city would entail building a new pier or rebuilding another waterfont facility. The same difficulty would arise if the fishing industry were moved to another city. 
(b) Alternative Designs

Renovating the Boston Fish Pier is by far the least expensive alternative available. Since purchasing the lease from the Boston Fish Market Corporation in 1972 Massport has considered several schemes entailing new construction. These schemes have been abandoned primarily because the capital costs of new construction are too great and can not be covered by the limited resources of the fishing industry.

\section{(c) Alternative Projects Having Similar Benefits}

The renovated Fish Pier will clearly improve the aesthetic and human environment along Northern Avenue. A revitalized fishing industry will stabilize the 1100 jobs that exist at the Fish Pier and will foster an additional 3000 jobs by direct and indirect impact at the pier and along Northern Avenue. Renovation of the Boston Fish Pier will provide facilities for the fishing industry at an ideal location at a manageable cost.

No scheme or project involving new construction can claim the low cost figures of this project. No other location can claim the convenience of the Boston Fish Pier.

(15) Mitigation measures.

Measures will be taken to insure that debris does not enter waterways. 


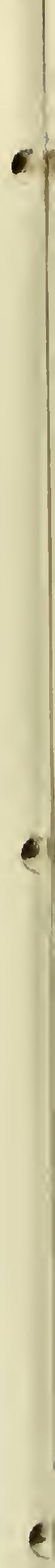


A parking plan will be implemented in the Northern Avenue Area. Included in the plans for the rehabilitation of the fish pier are measures for regulating truck traffic circulation and limiting parking on the Boston Fish Pier.

The modernization of fish processing facilities will reduce odors emitted substantially.

A gurry retrieval system will probably be installed on the pier during phase II of the renovation.

(16) Permits: for those received see EXHIBIT $11-A-8(1)(16)(b)$. 


\section{Population}

1970 U.S. Census Data

City Point

Telegraph Hill

Columbus Park

Andrew Square

West Broadway

D Street

Total: South Boston

City of Boston Total
11,378

10,144

5,750

2,222

5,455

3,539

38,488

641,071 


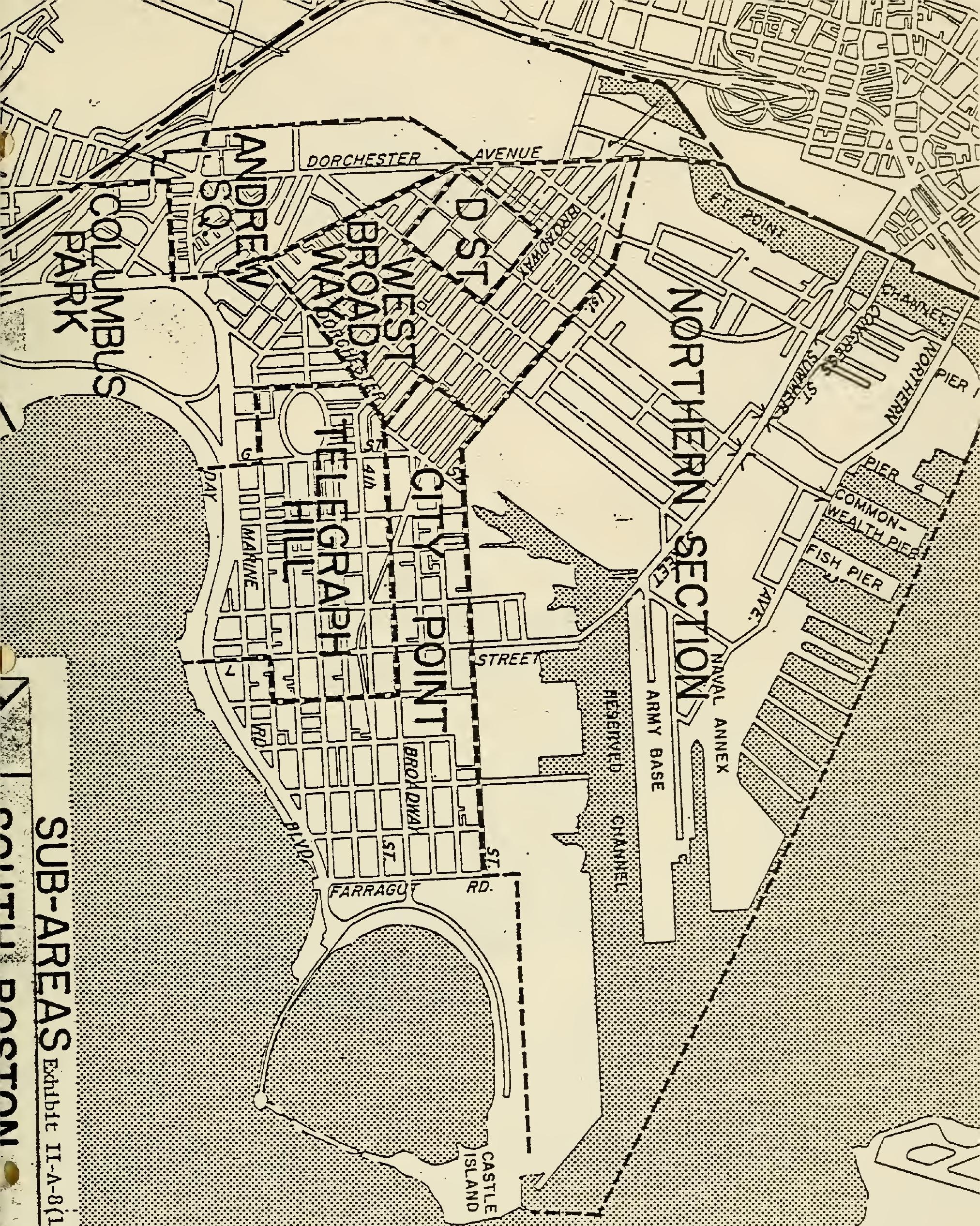


Exhibit II-A-8 (1) (b) 3(a)

SULFUR DIOXIDE (SO2)

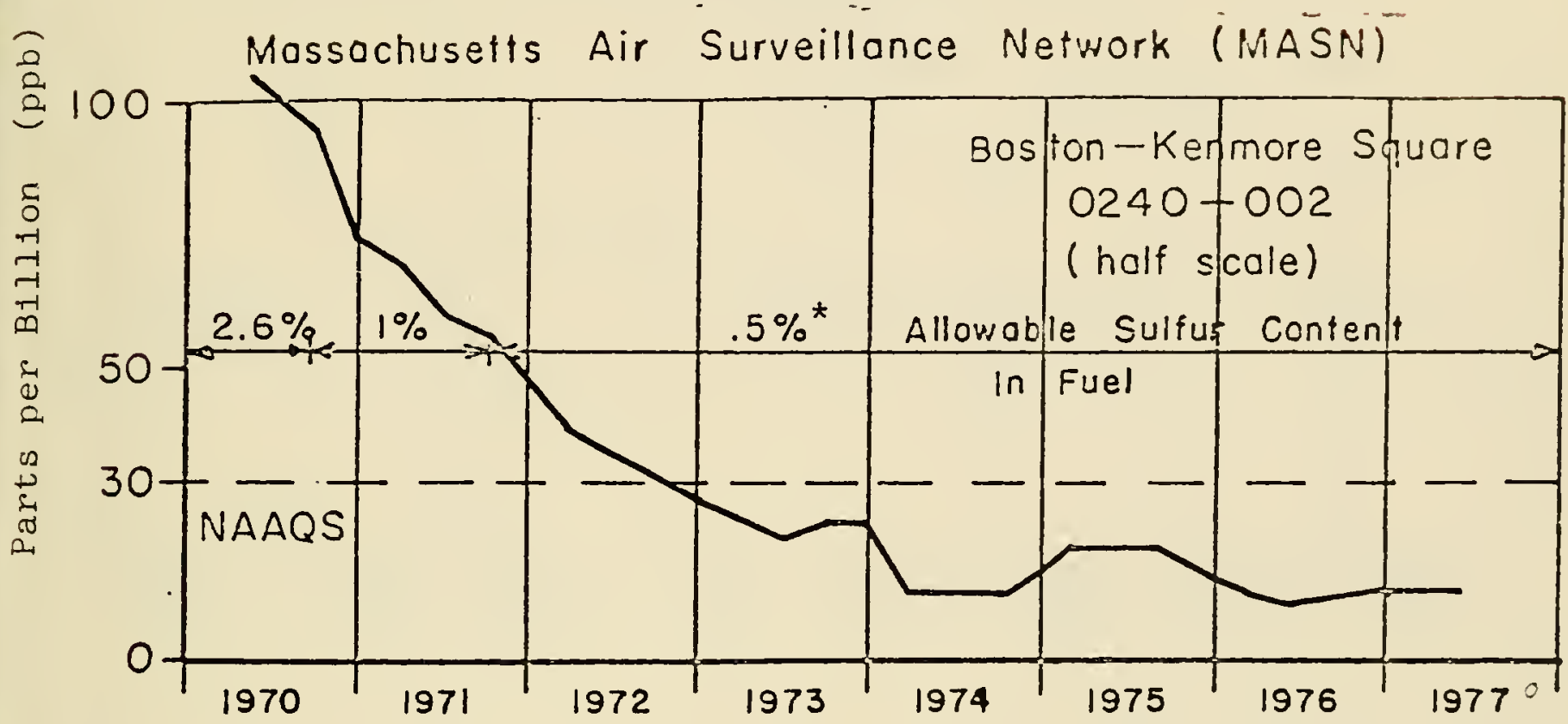

* Chapt. 494 started in July 1975

** Summary data for 1978 not available as of $4 / 9 / 79$.

WITHOGEN DIOXIDE $\left(\mathrm{MO}_{2}\right)$

ANNLAL ARITHRETIC PEANS - RUNIING AVERAGES

Massachusetts Air Surveillance Network (MASN)

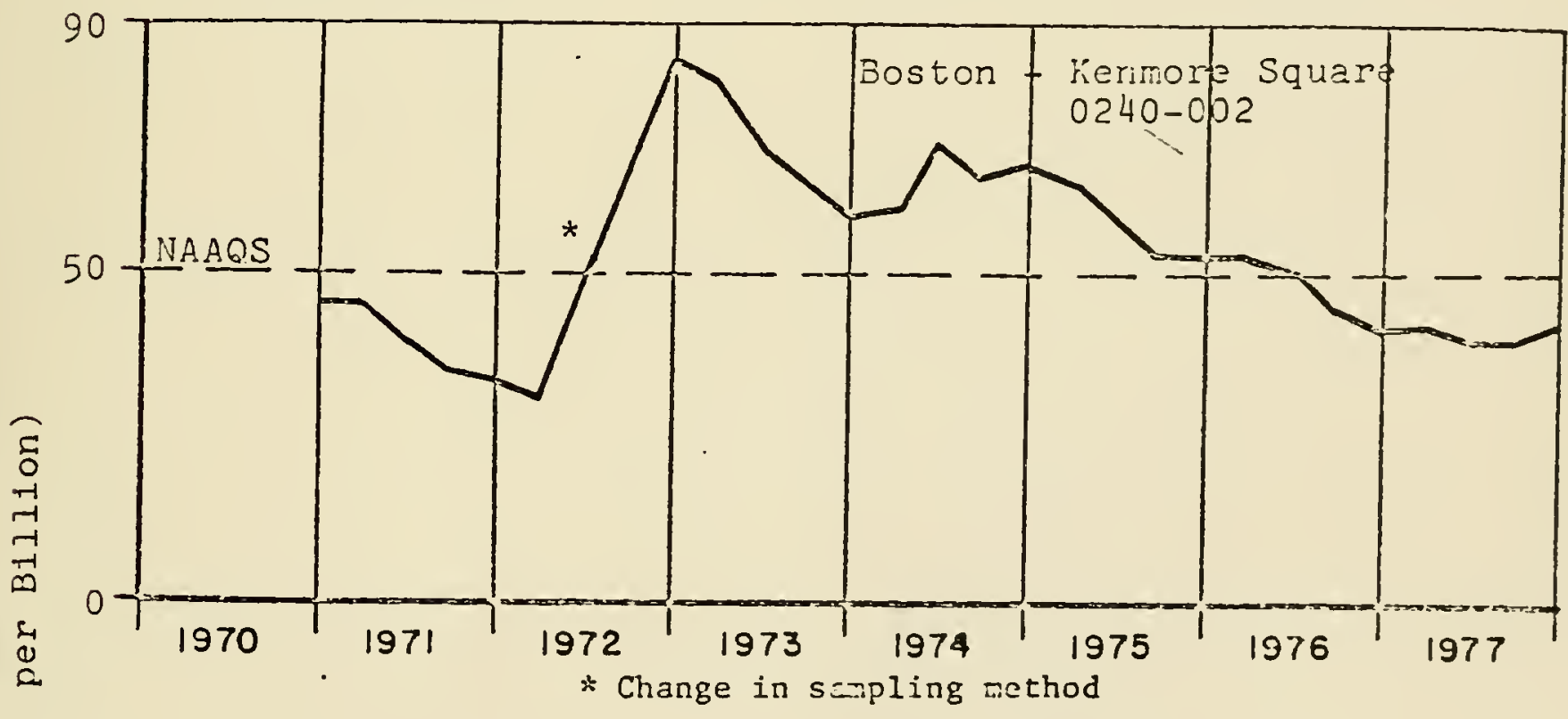


TOTAL SUSPENDED PARTICULATES (TSP)

ANNUAL GEOMETRIC MEANS - RUNNING AVERAGES

Massachusetts Air Surveillance Network (MASN)

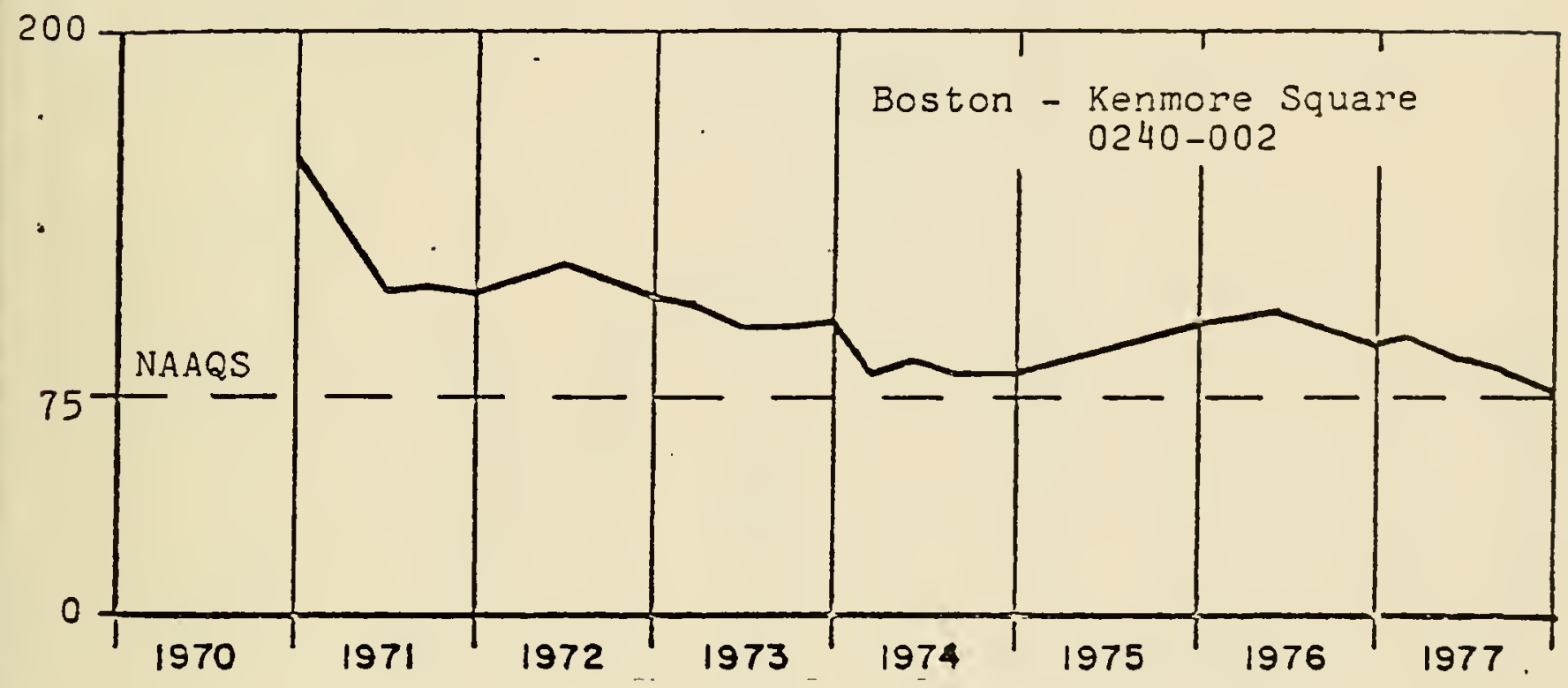




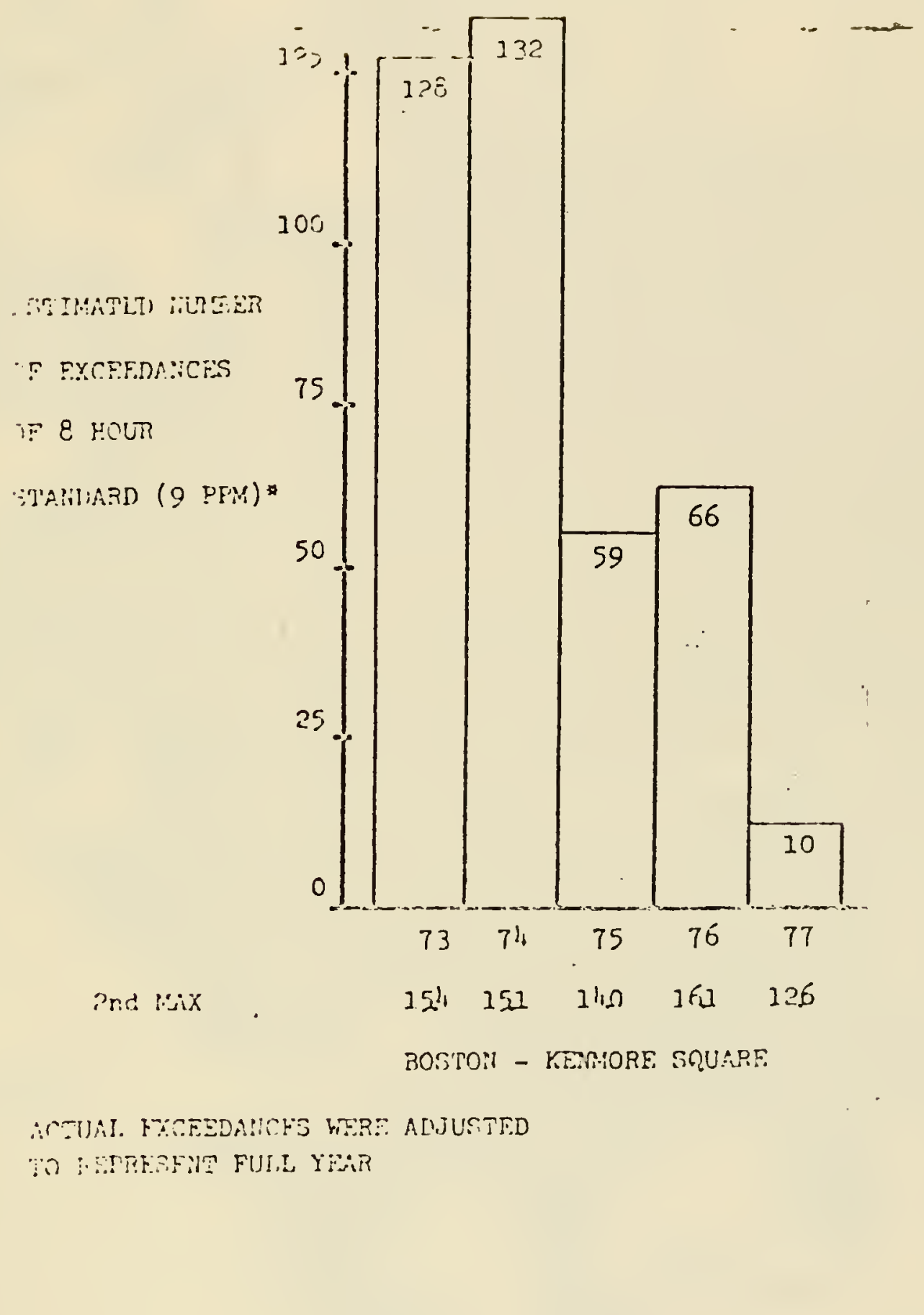




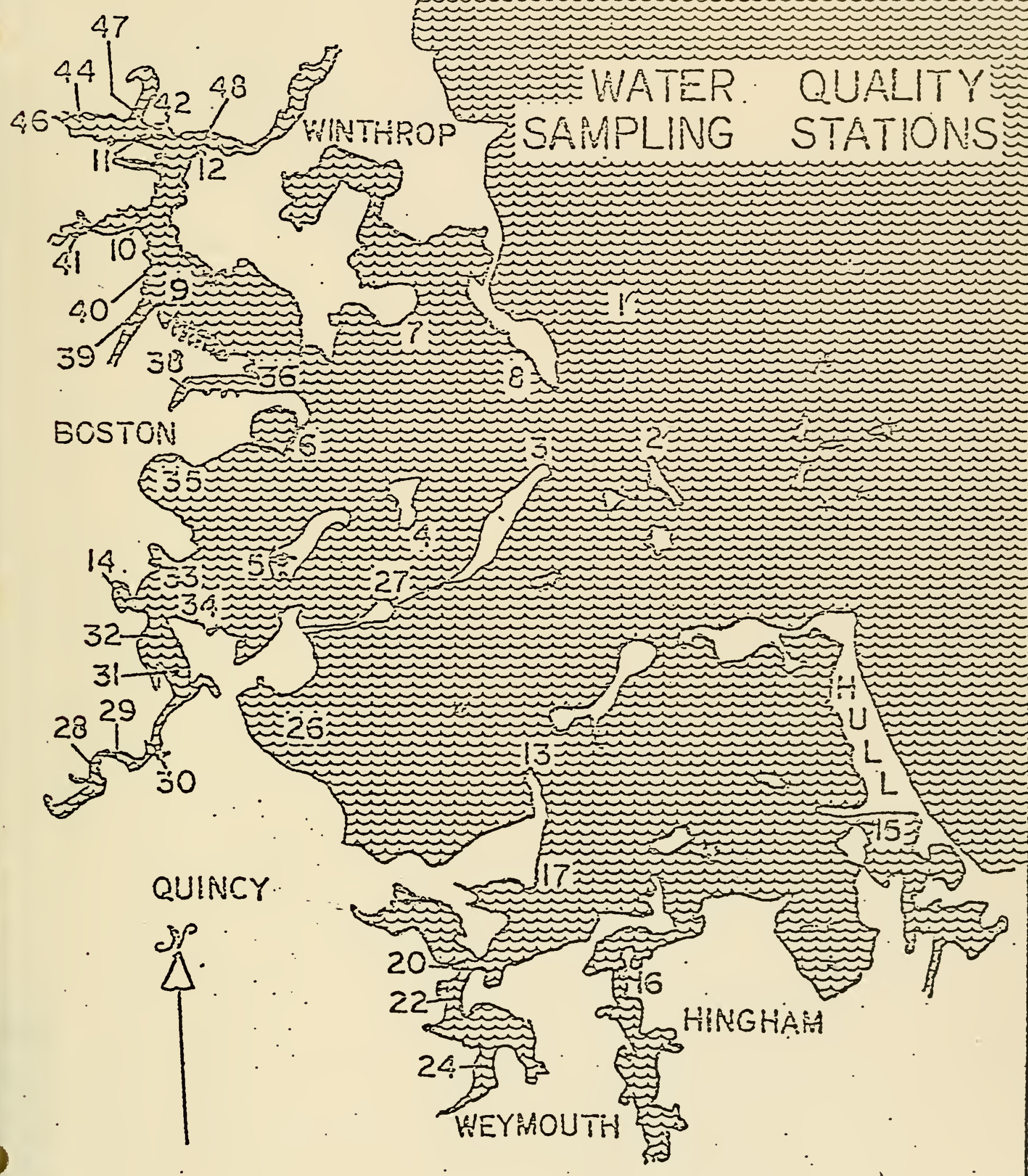


DIVISIOH OE HAIER POLIULIOA COHIROL

HETROPOLITFİ REGIOARL OEEICE

BOSEOY HAREOR SURYEY - 1972

STfTIOK No. 9 - Central hisef - 500 yerds off Aquarlum

\begin{tabular}{|c|c|c|c|c|c|c|}
\hline Secole tio. & R54781 & 855075 & $\mathrm{R} 55171$ & 555207 & E.55982 & R55994 \\
\hline Date of Collection & $6 / 5 / 72$ & $7 / 14 / 72$ & $7 / 20 / 72$ & $7 / 26 / 72$ & $11 / 2 / 72$ & $11 / 3 / 72$ \\
\hline Iinn of Collection & 1:00 PES & $10: 05$ A. & 1:35 Pis & $12: 47 \mathrm{PE}$ & 2:30 므뇩 & $12: 17 \mathrm{PH}$ \\
\hline Teuneratuze $\left(F^{\circ}\right)$ & $55^{\circ}$ & $59^{\circ}$ & $68^{\circ}$ & $63^{\circ}$ & $54^{\circ}$ & $45^{\circ}$ \\
\hline Lo: Tide & $12: 11 \mathrm{PrI}$ & $8: 31 \mathrm{AH}$ & 1:22 P: & 6:01 A: & $2: 39 \quad P 21$ & $3: 24 \mathrm{PH}$ \\
\hline$B C D$ & 3.0 & 2.5 & 6.7 & 2.5 & 3.2 & 0.9 \\
\hline $\mathrm{DH}$ & 7.4 & 7.7 & 8.1 & 7.9 & 7.1 & 7.6 \\
\hline Alicelinity-Totsl & 70 & 162 & 120 & 102 & 112 & 124 \\
\hline 9.0. & 2.8 & - & 7.0 & - & 3.6 & 4.3 \\
\hline Chlorties & 9400 & 14,600 & 13,400 & 15,400 & 14,000 & 17,400 \\
\hline Totel Solfds & - & - & - & - & $\vdots$ & $=$ \\
\hline SusD. Solfds-Total & 6 & - & - & - & $=$ & - \\
\hline Loss & $=$ & - & $=$ & $=$ & $\therefore$ & - \\
\hline Total ? & 0.22 & 0.24 & 0.24 & 0.14 & 0.36 & 0.12 \\
\hline Colifora-Totsl & 240,000 & 930,000 & $24,000^{\circ}$ & 93,000 & 240.000 & 43.000 \\
\hline Fecal & 24,000 & $230,000^{\circ}$ & 24,000 & 15,000 & 93,000 & -4300 \\
\hline Color & 55 & 25 & 45 & 28 & 18 & 20 \\
\hline Iuzbidity & $i$ & 0.0 & 1 & 0 & 1 & 0 \\
\hline ToLEI-KI-K & 0.8 & 1.0 & 1.4 & 0.7 & $=$ & $=$ \\
\hline$\hat{s}=0 \pi 1_{2}-N$ & 0.18 & 0.28 & 0.05 & 0.26 & 0.60 & 0.24 \\
\hline Aitrite-N & - & - & - & - & $\therefore$ & - \\
\hline Mitrete-H & 0.0 & 0.0 & 0.0 & 0.0 & 0.0 & 0.0 \\
\hline & & & & & & \\
\hline
\end{tabular}


DIVISLCH OE HUIER FOLIUIOU COH:AOL

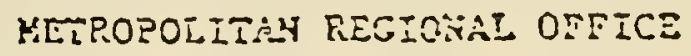

DOSTOL HASEOR SERTE: - 1972

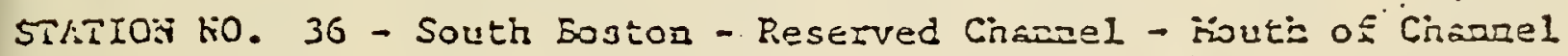

Servie kio.

iete of Collection

Tin:e of Coilection

Iempersinge $\left(F^{\circ}\right)$

intisie

BOD

$\mathrm{pH}$

AliknInity-Totsl

.0.

Colorices

Totel Solids

Susd. Solfás-Total

Losis

Total ?

Colifor=-Tatal

Fecal

Color

Terbidity

TOL=L-RI-H

Asmonic-H

Kitrite-s

Kltcate-4

(

(n)

(2)

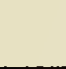

\begin{tabular}{|l|l|l|l|l|}
\hline 55480! & E54937 & 855109 & E55563 & R55714 \\
\hline
\end{tabular} \begin{tabular}{l|l|l|l|l|}
$0 / 6 / 72$ & $0 / 20 / 72$ & $7 / 15 / 72$ & $8 / 15 / 72$ & $9 / 12 / 72$
\end{tabular}

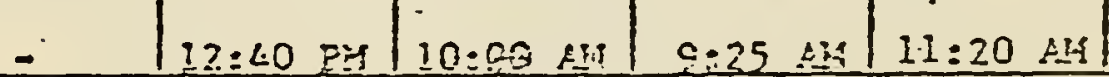

$\therefore 65^{\circ}$

\begin{tabular}{l|l}
$1: 07 \mathrm{FH}$ & $1.15 \mathrm{PH}$ \\
\hline
\end{tabular}

24.48

$a_{2}$

2.0

7.8

7.9

\begin{tabular}{l|l|l}
7.4 & 7.8 & 7.1 \\
\hline
\end{tabular}

108

Ias

93

6.3

7.6

8.1

6.8

6.9

9000

12.400

15.000

16.600

15.400

.

4.0

3.0

-

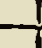

$\because$

0,12

0.20

0.14

0.08

0.10

1.

75.000

240,000

24.000

4320

23.000

$<400$

1

.

48

1

1

1

0.8

c. 30

0.25

요

4390

$\because 23$

$\left|\begin{array}{l}0 \\ 4.5 \\ -\therefore\end{array}\right|$ 


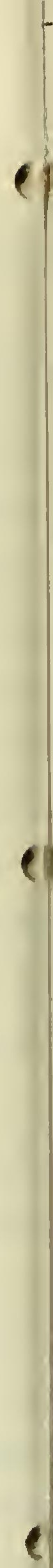




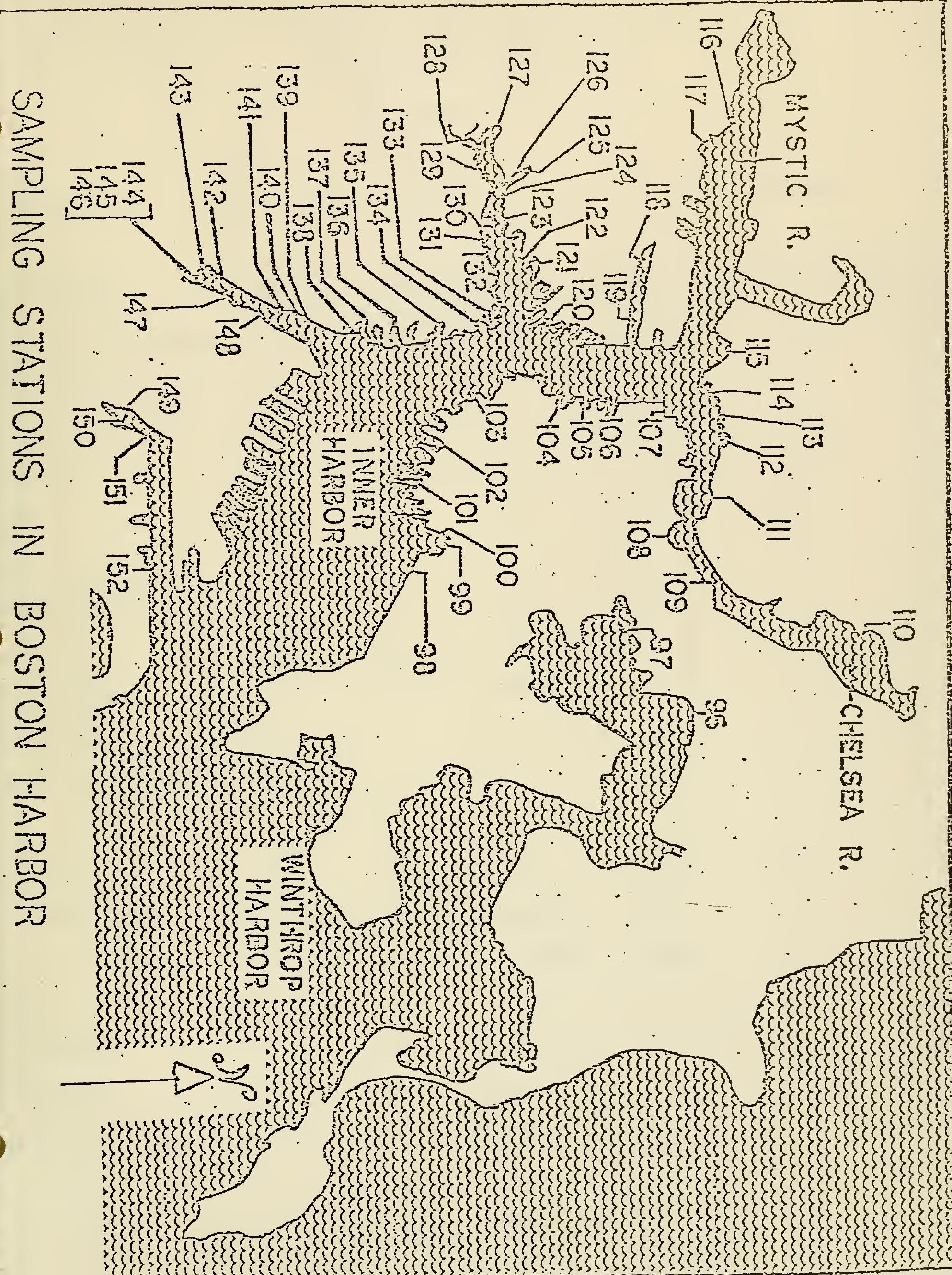


DIVISIGY OF UAIER YOLILIIORI CONTROL

KETROPOLITA: REGIC:HI OEEICE

BOSTON FNRTOR SURVEL - 1972

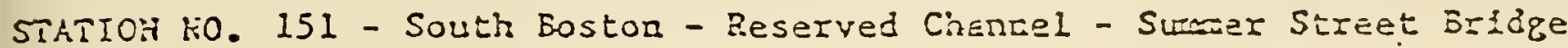

\begin{tabular}{|c|c|c|c|c|c|c|}
\hline SEGile lio. & 854813 & 254950 & R55121 & 255486 & & \\
\hline Date of Collectica & $6 / 6 / 72$ & $6 / 20 / 72$ & $7 / 18 / 72$ & $8 / 15 / 72$ & & \\
\hline Time of collection & $12: 15$ fis & $1: 05 \mathrm{PH}$ & $10: 13 \mathrm{RI}$ & $10: 15 \mathrm{~A}=1$ & & \\
\hline Tecoezatuze $\left(F^{\circ}\right)$ & $60^{\circ}$ & - & - & - & : & \\
\hline Low Tice & 1.:07 Pif & $1=15 \mathrm{PK}$ & $11: 37$ ANS & 10:07 RIS & . & \\
\hline$B O D$ & 3.0 & 2.4 & 2.3 & 2.2 & - & \\
\hline $\mathrm{pH}$ & 7.3 & 7.5 & $7 . .7$ & 7.6 & $:$ & \\
\hline Alkalinity-Total & 74 & 96 & 102 & 104 & & \\
\hline 7.0. & 7.1 & 6.4 & 7.2 & 6.8 & & \\
\hline Crilozides & 10,000 & 14,800 & 15,400 & 16,400 & & \\
\hline Totel Solids & - & - & - & - & . & \\
\hline Susp. Solfds-Tosal & 4.0 & 4.0 & - & 3.0 & & \\
\hline Loss & - & $=$ & - & - & & \\
\hline Totel P & .18 & .20 & .16 & .12 & & \\
\hline Collfora-Total & 240,000 & 24,000 & 43,000 & 430 & & \\
\hline Fecal & 15,000 & 4300 & 43,000 & $\cdot 36$ & $\cdot$ & \\
\hline Color & 43 & 0 & 20 & 10 & - & \\
\hline Iurbidity & 1 & 20 & 1 & 1 & - & \\
\hline Tctel-Ki-!I & 1.5 & 0.4 & 0.4 & 0.4 & & \\
\hline$\therefore \operatorname{con} 1 \varepsilon-N$ & .21 & .23 & .25 & $\therefore .16$ & & \\
\hline Derite-k & - & $=$ & $=$ & - & & \\
\hline Pitrate- & 0.0 & 0.0 & 0.0 & 0.0 & & \\
\hline
\end{tabular}


EOS:ON FHEOR SUSYEY

SEDTMETT RHAEYSIS

$\mathrm{Hp} \quad \mathrm{Cd} \quad \mathrm{Pb} \quad \mathrm{Zn} \quad$ iri.

Cus

$C_{I}$

As 7 Vo?.

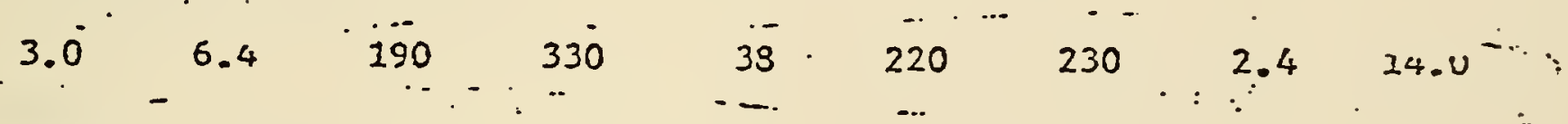

$\begin{array}{rrrrrrrrrr}20.5 & 15.0 & 740 & 1400 & 110 & 550 & 180 & 3.6 & 25.0 \\ 4.0 & 13.0 & 850 & 950 & 77 & 590 & 180 & 5.4 & 29.0 \\ 2.9 & 9.1 & 440 & 750 & 100 & 440 & 84 & 9.2 & 13.0 \\ 3.0 & 5.7 & 460 & 1550 & 80 & 550 & 58 & 6.0 & 14.0 \\ 2.0 & 6.6 & 110 & 170 & 73 & 140 & 100 & 8.0 & 20.0 \\ 1.6 & 4.0 & . & 140 & 250 & 40 & 150 & 180 & 5.0 & 9.6\end{array}$

OTE: Concentrations reported es mg/kg dIy weight passirg io. 30 sleve. 
6 
MINTZ ASSOCIATES ARCHITECTS/PLANNERS, INC. One Dock Square Building Boston, Massachusetts 02109(617)523-3705

\section{MEETING SUMMARY}

Fish Pier Program Committee

Meeting \#1

26 September 1978

At Mintz Associates; 1:30 PM

\section{Present:}

Committee: Frank Byrnes: F.E. Harding Co.

Vito Corseli: Great Atlantic Co.

Frank Foley: F. J. Foley Co.

Russ Nagle: John Nagle Co.

Hugh O'Rourke:Boston Fisheries Assoc.

Bill Stride: Turner Fish Co.

John Stride: Turner Fish Co.

Massport: Elliot Friedman

Gail Monahan

Bob Parks

Debbie Kaplan

Mintz Assoc:Sy Mintz

Bi17 Yuhas

\section{SUMMARY:}

Elliot and Sy outlined some objectives of the Committee including the following:

Input for programing of Fish Pier Rehabilitation;

Open discussion of all alternatives and issues;

Best possible solutions considering individual needs and overal1 needs;

Bring all ideas -old and new- to the Comittee for discussion; 
Inform other Fish Pier tenants of activities of the Committee;

Discuss one key issue or designs question at each meeting.

The issue discussed was that of traffic circulation on the Pier including loading and unloading of trucks, circulation plans, restricted access areas, autos on the pier and a central shipping area.

Conclusions:

The following outlines those areas where the Committee reached a concensus on specific issues:

1. Automobiles -all automobiles- should not be allowed on Pier. Autos were identified as the major cause of conjestion.

2. Straight (perpeudicular) unloading at the sheet truck docks should be continued. Angled unloading does not allow for adequate dock frontage.

3. Trucks must be allowed access onto the apron area of the Pier (backs of stores). This area might be limited to the unloading of fish only.

4. A Pier traffic circulation plan is needed. It should consider advantages/disadvantages of one way traffic, off-pier parking for dealers trucks, and a clearly marked roadway (perhaps $12 \mathrm{ft}$. wide) on the apron to separate traffic from dealer work areas.

5. A central shipping area is not practical at this time.

Next Meeting:

A circulation plan of the Pier including a roadway and work area dimensions on the apron will be prepared for the next meeting.

Bob Parks will notify members of the next meeting. Wednesday or Thursday afternoons were agreed upon as the best meeting time. 
MASSACHUSETTS PORT AUTHORITY - BOSTON FISH PIER TENANTS

DEVELOPMENT COMMITTEE

Attendance at the september 26, 1978 meeting is as follows:

Sy Mintz

Joe Guerino
Frank Byrnes

Russell Nagle

Hugh O'Rourke

Bill Stride

John Turner

Frank Foley

Vito Corsile
Elliot Frledman

Bob Parks

Debbie Kaplan

Gale Monahan

Th1s Committee was formed at the suggestion of the Massachusetts Port Authority to discuss items that relate to the rebuliding of the Boston Fish Pier, some of which are immediate and others pertain to the future.

The principle parties attending this meeting are representatives of the Massachusetts Port Authority, The Boston Fish Pier Tenants, and Mintz Associates Architects/Planners, Inc. It was suggested that meetings be held periodically as subject matter develops that requires implementation.

The meeting held at the office of Mintz Assoclates, Tuesday, September 26, 1978, was concerned with truck loading and unloadIng procedures, regulating traffic, and the need for eliminating passenger automobiles on the Fish Pler excepting in emergencies. The Fish Pler was constructed in 1910-1914 during the era of the horsedrawn teams and provided adequate space for maneuvering. Today, the Fish Pier is clogged with semi-trailers on two different times of the day. In the morning fish arrives over the road from various New England Ports and Canada, and in mid-afternoon to early evening trucks arrive to transport the finished product to the Marketplace within a 1,000 mile radius of Boston.

At the beginning of the meeting Sy Mintz had layouts posted on the walls of his meeting room showing physically two plans related to loading and unloading. One plan was designed to back the trucks into loading platforms on a right or left angle based upon which side of the pier they were unloading. The second plan was to back the trucks squarely against the Pier loading facilities in a straight line. It was the concensus of the Tenants Committee that the trucks should not be backed in on an angle. It was decided that the trucks should be unloaded by backing directly into the loading platform. 
The delivery of fresh flsh over the road to the Boston Fish Pier requires that trucks unload at the back of the flsh plants. Several reasons were offered but primarily it is a procedure that has found acceptabllity over the years following trial and error. The advantage $1 \mathrm{~s}$ that the fish can be stored at the back of the Pler temporarily and be close to the process line minimlzing the need for additional space and labor.

Traffic patterns are also being considered that will maintain a good traffic flow thereby minimizing traffic jams on the Pler. It was definitely agreed that no private vehicle can park on the Fish Pier irrespective of time of day. Obviously during reconstruction of the Fish PIer there wiII be construction vehicles, suppliers, and dumping equipment that will require space. This will be a mobile operation relating to the confusion of rebuilding one side of the Pier and moving plants across the Pier. This dictates that the sooner a traffic pattern is established and adhered to by the Fish Pler Tenants it will minimize lost time due to traffic congestion. 


\section{MEETING SUMMARY}

FISH PIER PROGRAM COMMITTEE

MEETING \#2

12 OCTOBER 78

AT MINTZ ASSOCIATES: I:30 P.M.

PRESENT:

COMMITTEE: FRANK BYRNES: F.E. HARDING CO.

RUSS NAGLE: JOHN NAGLE CO.

HUGH O'ROURKE: BOSTON EISHERIES ASSOC.

JOHN TURNER: TURNER FISHERIES

MASSPORT: ELLIOT FRIEDMAN

BOB PARKS

GAIL MONAHAN

MINTZ ASSOC: SY MINTZ

BILL YUHAS

\section{SUMMARY}

Elliot informed the Committee that Massport is meeting with No Name Restaurant owner, Nick Contos regarding their lease. It was suggested that when we are further along technically, and better understand the implications of rehabilitation of the buildings, Nick should be involved in matters affecting the No Name.

As a follow-up to the last meeting, Bill Yuhas presented a sketch of the apron area showing an $18 \mathrm{ft}$. wide truck roadway and a 28$30 \mathrm{ft}$. wide work area.

Questions: -Should the truck roadway be set back from the cap log? -How will this effect the proposed new canopy?

-What uses will be continued on the apron?

Suggestions: -Pier tractors should operate two-ways.

-Trucks should be Iimited to one-way.

-Traffic pattern should be flexible to respond to future needs. 
MINTZ ASSOCIATES ARCHITECTS/PLANNERS, INC.

\section{MEETING SUMMARY}

PAGE TWO

\section{Conclusion}

It is necessary to look at the apron area in more detail, to survey user needs, develope canopy design alternatives, paving alternatives and discuss in more detail at a future meeting.

The central issue discussed was that of dealer layouts at the first and second floors of buildings 1 and 2. Mintz Associates presented sketches generally showing the following:

Floor 1:

All processing

Cold storage

Small office (shipping \& receiving)

Toilet

Floor 2: Offices

Locker Room w/showers \& toilets

lunch room

storage area

Mechanical equipment area

Also shown was an open area in the second floor allowing for visual surveillance and verbal contact from the second floor to the first floor. General comments are as follows:

Coolers: Flexibility could be important but cost will be an important factor.

- Major concern is heat transfer.

-Coil coolers are more efficient, fan coolers melt ice to quickly.

-Access door directly off the apron may be desirable in larger coolers.

-Temperatures: 36 degrees to 38 degrees ( 34 degrees ideal) = Coolers; -10 degrees $=$ freezer

2nd Floor

Access:

-Floor opening will depend on individual need and a function of needed floor area.

- Access through a canopy hatchway should be considered further along with an interior hoist through a floor hatchway.

Processing: -Processing lines do not have to be front-to-back but could also be across the store area. A need is for adequate space for the temporary holding of fish prior to processing. The canopy will provide a protected area for fish holding. 
MINTZ ASSOCIATES ARCHITECTS/PLANNERS, INC.

MEETING SUMMARY

PAGE THREE

\section{Conculsions}

General layout as shown in the sketches is $0 . K$. Specific design layouts will be worked out with individual dealers in Phase II.

Most if not all dealers need more space or at least more efficient space, particularly cold storage.

The smallest dealer bay would be $30 \mathrm{ft}$. wide.

The issue of dealer: layouts will be discussed at subsequent meetings as this phase of the project is developed.

\section{Next Meeting:}

A detailed evaluation of apron uses, needs and canopy design alternatives as well as truck circulation and surface treatment will be presented at the next meeting.

Bob Parks will notify committee members of the next meeting and any additional issues to be discussed.

Submitted by:

Bill Yuhas

copies to all present 
MINTZ ASSOCIATES ARCHITECTS/PLANNERS, INC.

MEETING SUMMARY

FISH PIER PROGRAM COMMITTEE

I.EETING \#3

AT MINTZ ASSOCIATES @ 1:00 P.M., December 6,1978

PRESENT: FPPC: Vito Corseli

Frank Byrnes

Frank Shinney

Russ Nagle

Bill Stride

John Turner

MPA: Elliot Friedman

Gail Monahan $\checkmark$

Debbie Kaplan

Bob Parks

BFA: IJugh O'Rourke
MA: Sy Mintz

Bill Yuhas

\section{Sumary}

As concluded at the last meeting, Mintz Associates have evaluated apron uses and canopy design alternatives. The purpose of meeting was to review alternative canopy, truck dock and apron uses and design. Alternatives included the following:

Truck dock side: Suspended canopy with options for the width of the loading platform from the existing width of approximately $4 \frac{1}{2}$ feet to 8 feet.

Apron side: Suspended canopy - 12 feet to 16 feet chain link fence enclosure, 8 feet high, 22 feet out fran building.

Three, column supported canopies.

1. One story, partially covered, enclosed with chairn link fence.

2. One story covered and enclosed with overhead doors.

3. Two story, covered and enclosed, overhead doors and storage loft.

Since canopy treatment directly effects design and treatment of exterior rehabilitation, it is necessary to decide on a canopy design so that work can proceed on exterior rehab that allows for future improvements.

1. Sy Mintz presented alternatives.

a. Truck Dock Side: Dock width and canopy.

Coments: Could use a wider platform width.

Most want to be able to maneuver a fork lift along the platform.

Also, must be able to open truck doors after the truck has backed in.

Regarding street width, dealers and truckers can control circulation - self patrolled. It was restated that cars, not trucks, creat the traffic problem on the Pier.

The canopy is necessary for protection from weather.

Two foot overhang beyond truck dock should be adequate. 
MINTZ ASSOCIATES ARCHITECTS/PLANNERS, INC.

MEETING SUM:IARY

FISH PIER PROGRAM COMMITTFE

MEETING \#3

PAGE TWO

Conclusions: Set truck dock to accarmodate fork lift maneuvering on the platform, likely 6 to 7 feet.

Ideal truck dock height would be 48 inches.

Canopy to extend 2 feet beyond truck dock.

b. Apron Side: Canopies and layouts.

The apron survey and evaluation findings showed that all dealers, no matter how large or small, utilize approximately 22 feet of apron out from their store (the apron is 48 feet wide) for fish unloading, weighing and holding, box storage, gurry, etc. The rest of the apron is used primarily for vehicular circulation (trucks and warf trailers), dumpsters and boat access. Based on these findings all canopies or enclosures included this 22 foot area.

Comments:

Initial reaction was in favor of 2-story canopy.

Major concern was regarding additional costs to tenants in terms of rents and operating costs.

Loft space was considered as optional.

Still stronger response in favor of 2-story canopy.

General approval of apron uses: truck circulation, dealer uses (unloading, weighing, storage, etc.) covered area.

Two story is as valuable to a one-baystore as it is to a four bay store.

It would allow the processors to take in new products such as squid and whiting.

Two lines are very beneficial to cost of operation in tems of changed over to different species. If more species could be cut, more boats would come to Boston.

New enclosed space under canopy is rentable and could be an alternative to expanding to an additional bay. 
MINTZ ASSOCIATES ARCHITECTS/PLANNERS, INC.

MEETING SUMMARY

FISH PIER PROGRAM COMMITIEE

MEETING \#3

PAGE THREE

Conclusion: Two story canopy solution was chosen as the alternative to be developed further. More accurate costs will be developed regarding the econamic feasibility.

2. General

Special consultant: Sy discussed the hiring of Johan Koppernaes and his eventual start to evaluate fish unloading, gurry handling, freezing, cold storage and ice making. We will be meeting with him soon and these meetings will include the Fish Pier Program Conmittee.

3. Next Meeting

Massport and MA will address questions raised at this meeting regarding the selected canopy design.

Bob Parks will inform the Camittee of the next meeting and agenda items.

Submitted by:

Bill Yuhas

/mtf

copies to all present 


\section{Exhibit II-A-8(1)(b)(13)(c)}

Boston Globe

\section{$9 / 15 / 78$}

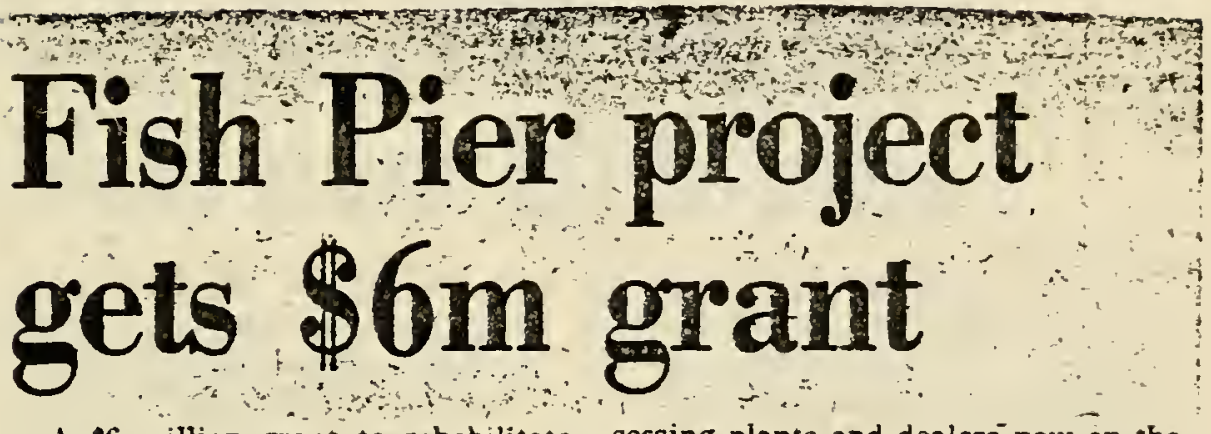

A $\$ 6$ million grant to rehabilitate Boston's dilapidatect, 65-year-old Fish Pier was approved yesterday by the US Commerce Department's Economic Development Administration.

Rep John J: Moakley (D-Mass.) who has been pressing for the federal fund for more than a year, announced Is Wrohington that $\$ 2$ miltion has been committed for the current fiscal year and $\$ 4$ million more for 1979 and 1980

$\therefore$ Modkley estimated the Fish Pier re novation will create 2790 constriction and fiabing-relate jobs in Bosten He cilled the projeet vital Iints in the urban renewal effort already under cessing plants and dealers now on the pier. "and provide room for new-busi.. nesses to handle the increased supplies. of fish: we expect because of, the 200 . mile limit" in sucto on Lt Gov-Thomas P O'Neill 3d said the project will bring the Boston fishing industry out of the dark ages ${ }^{-} \mathrm{He}$ said the Fish. Pier desperately jeeds updating NAr official in O' Neill's office said canstruction is expected to start it the spring and last two years, He said the Wree majos buildiggs on the pies and the power plant will Ge restored way throughout Boston's wateriont of area. ETh unloading and rce facilities wili

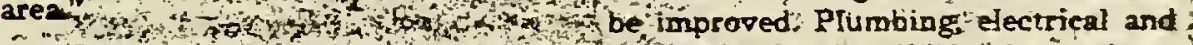
a Apokesman for the Bóston Ir her-" sewage gystems will also be modernies Assn Hugh ORourke sad whis -ized or or will be a real shot in the arm for the

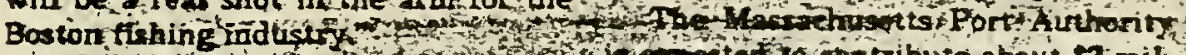

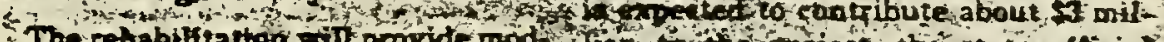
The retabitization win provide mod ton to the project the state afticial

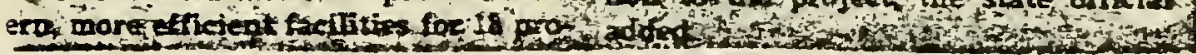




\section{Exhibit II-A-8(1) (b) (13) \\ Boston Herald American}

$9 / 15 / 73$

\section{Fish chief forecasts 2,800 new Hub jobs}

The presiderit of the Boston Fisheries Association said yesterday that a recently-approved $\$ 6.5$ millior federal grant for renovation of the Boston Fisher Pter will pump new life into the city's fishing industry, resulting in 2300 new jobs.

The 20 tenants occupying the withering Massachusetts Port Autharity facility on Northern Avenue were in danger of having their fish processing and wholesale firms closed down, said Francis M. Bytnes, president of the Fisheries Association.

Byrnes predicted that the grant, which will be used to make interior and exterior improvements, will create a more vibrant atmosphere at the pier.

"I would say that in five years, you'll see anywhere from three to five times as many employees here," said Bymes, who oums a company on the pier.

Massport Executive Director David W. Davis said improvements on the 65-year-old facility will enable Boston to focus on "bigger and better" markets by parjayiug a bealthier fishing industry with the transportation eapabilities of nearby Logan Airport.

Davis said site improvements would begin next month with a $\$ 2$ million allocation for fiscal 1978. The remaining $\$ 4.5$ million would be used during the later phases of construction, which will be completed by 1980 .

"What we're trying to do is attract more boats to bring their catches to Boston, and with a decadent fish pier, you can't do that," said Bymes.

He added that the fish pier would probably have been closed down by the state's Food and Drug Administration if the rehabilitation grant from the Economic Development Administration had not been awarded.

Byrnes credited U.S. Rep. J. Jo seph Moakley, House-Speaker Thomas P. O'Neill Ir, Massport, the Boston Fisheries Association and Boston Fish Pier Tenants Group ior convincing the federal government that the pier is in grave net of renovation work- 
11-A-8 (1)(14)(6) Permits Received

Department of the Army, New England Division, Corps of Engineers

Commonwealth of Massachusetts Historical Commission

Commonwealth of Massachusetts: Executive Office of

Environmental Affairs: Approval of decision not to prepare an environmental impact report (Negative Assessment) for Rehabilitation of Boston Fish Pier

Notification of Massport's digibility to purchase flood insurance for Boston Fish Pier 


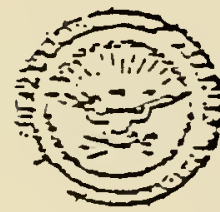

DE.А.Т.MENT OF THE ARMY

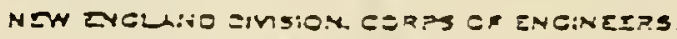

LETRAPED PCAO

WALTHA.M. MASSACHLYSTS S2:24

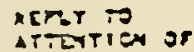

$\lambda=0-3-20$

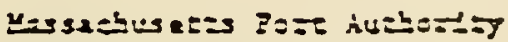

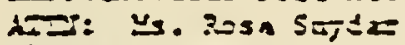

99 टिक्ष 5 =eet

pos=s, vessaciuseres 02110

Ger-10:

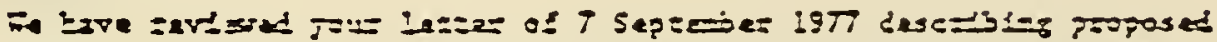

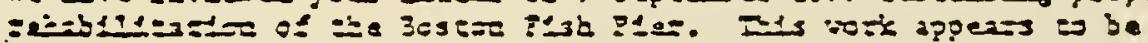

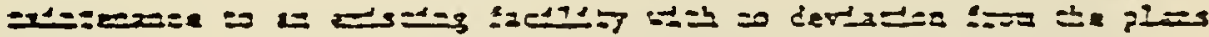
=- use of the off z=20.1.

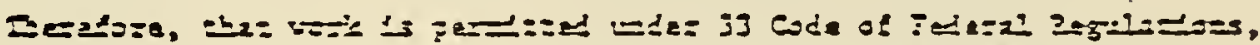

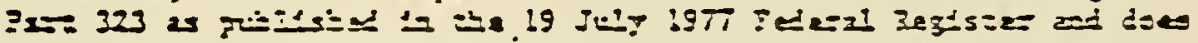

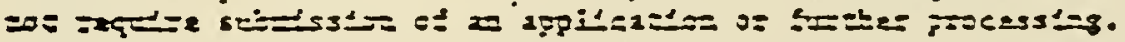

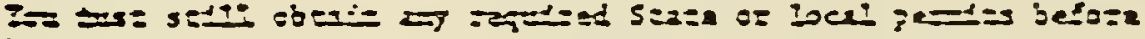

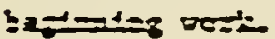

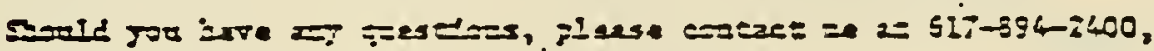
Cexice 333.

Sisereit gots,
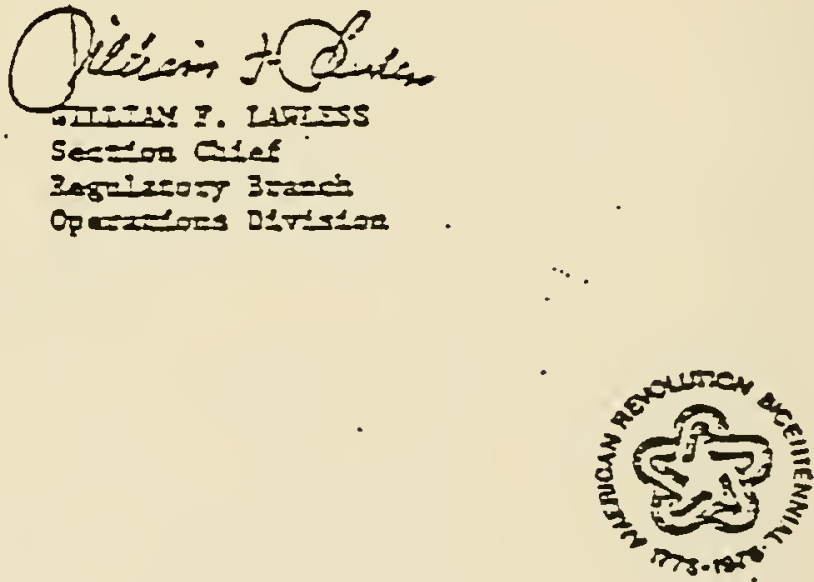
April 6, 1978

Mr. Elliot Friedman

Massachusetts port Authority

99 High Street

Boston, Massachusetts 02110

Dear Mr. Friedman:

The Massachusetts Fistorical Commission has reviewed the proposal for renovations to the Boston $F$ ish pier and has determined that the proposed action hill have no effect on historic properties listed or eligible for listing in the National Register of Historic Places.

Thank you for the opportunity to review and comment. We encourage you in your endeavors to revitalize a property associated with such an important aspect of Boston's history and hope that you will continue to consider historic properties during planning for your agencies' developments and act ivities.
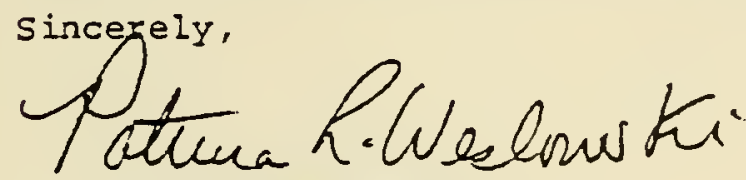

Patricia I. Weslowski

Acting Executive Director Massachusetts Historical Commission

Deputy State Historic Preservation Officer

$\mathrm{PLW} / \mathrm{JRO} / \mathrm{Pg}$

xc: Frank Barnes 


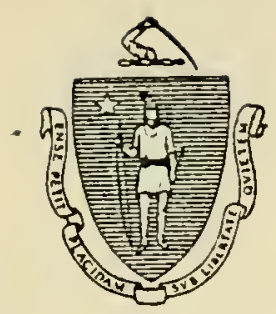

EVELYN F. MURPHY SECRETARY
The bommonwealth of Massachusetis

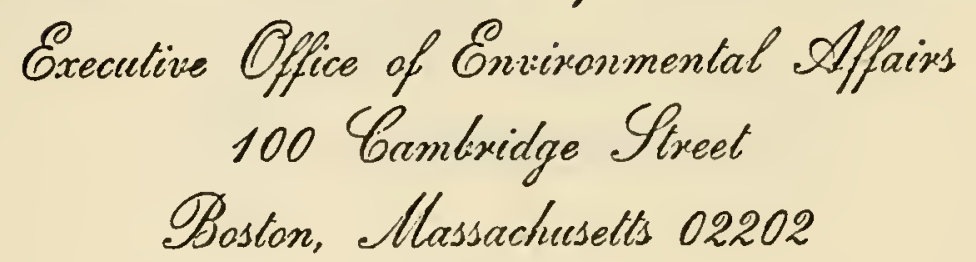

$\underline{M} \underline{E} \underline{M} \underline{O} \underline{R} \underline{A} \underline{N} \underline{D} \underline{U} \underline{M}$

TO: Norman Farame11i, Massport

FROM: Evelyn F. Murphy, secretary Ef Ohy

DATE: March 14, 1978

SUBJECT: EOEA $\equiv_{02}$ 2879, Northern Ave. Fish Pier Modernization

In my judgement this activity does not require the preparation of an Environmental Impact Report. However, there is an issue that applies to all projects in the Northern Avenue area-traffic. The BMIP, the Fish Pier Modernization, and all the development schemes for the area will each have substantial traffic generation impacts. While each:seems of a minor degree, they add up to major traffic levels through the area with project completions. I therefore urge Massport to coordinate their efforts with other related developments in the area, and to initiate discussions with other agencies aimed at provision for mass transit services and roadway improvements.

REG: jmdi

cc: Jeff Simon, Land Bank

John Carroll, DPW

Richard Mertens, BRA

Secretary Salvucci, EOTC 


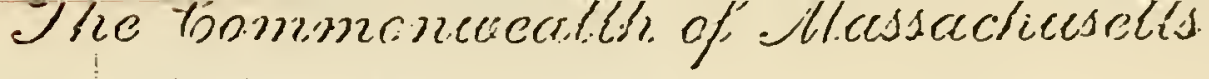

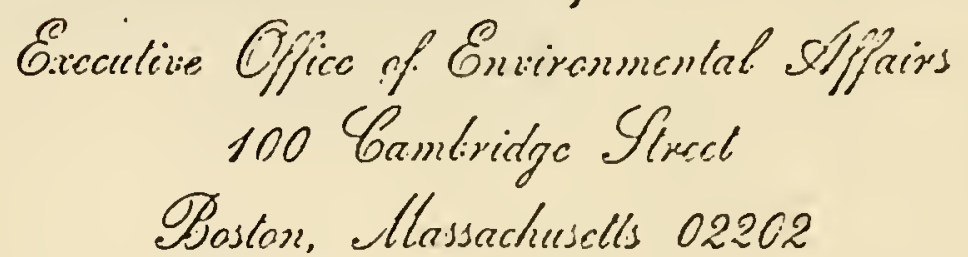

EVELYN F. MURPHY SECRETARY

\section{STATEIEITT OF SECRETAPY OI ERVIROITEITAL - ASSESSMENT FOR:1}

Pursuant to M.G.L., Ch. 30, S. 62, and the rezulations gorerning preparation of environmental impact reports, the Secretary of Enrironmental Affairs herein issues the following statement with respect to the Environmental Assessment Form submitted on the following project.

Environmental Assessment Form No. 02879

Submitted By: Massachusetts Port Authority

Date Received: February 14, 1978

Project Identification: Modernization of the Fish Pier on Northern Ave. STATEP.EITT:

$(V)$ 1. The decision not to prepare an environmental impact report (llegative Assessment) adequately and properly compiies with the provisions of the regulations.

( ) 2. The decision not to prepare an environmental impact report (Negative Assessment) does not adequately and propirly comply with the provisions of the regulations. See attached statement of reasons.

( ) 3. The decision to prepare a draft Standard Environmental Impact Report adequately and properly complies with the provisions of the Regulatjons.

( ) 4. The decision to prepare a draft Standard Environmental Impact Report does not adequately and properly comply with the provisions of the Regulations. See attached statement of reasons.

( ) 5. The decision to prepare a draft Extensive Environmental Impact Report adequately and properly complies with the provisions of the Regulations.

( ) 6. The decision to prepare a draft Extensive Environmental Impact Report does not adequately and properly conply. ith the provisions of the Regulations. See attached statement of reasons.

$\frac{3-15-78}{\text { DATE }}$

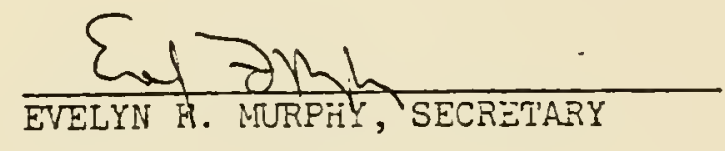




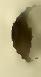

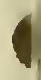




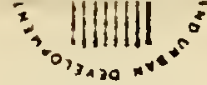

REG:ON I

Room 800

John F. Kennedy Federal Building Boston. Masachusetts 02203
BULFINCH BUILDING, IS NEH CHARDON STREET

BOSTCN, MASSACHUSETTS O2114

April 21, 1978

Norman J. Faramelli

Chief

Environmental Management

MASSPORT

99 High Street

Boston, MA. 02110

Dear Mr. Faramelii:

This is in response to your letter of April 17, 1978, reThis is in response to your
garding the proposed MASSPORT Fish pier renabilitation
project and the National Flood Insurance Program.

At the present time Flood Insurance is available within the City of Boston. As far as we know MASSPOKT is bound by the regulations Boston has adopted to comply with the requirements of the National Flood Insurance Program. If this is not the case please inform us. Flood Insurance may be purchased by anyone in the City of Boston. In order for E.D.A. to allow funds to be used for acquisition or construction purposes in an identified special flood hazard area flood insurance is required for the useful economic life of the project.

If we can be of further assistance, please do not hesitate to write or telephone us at 223-2616.

Sincerely,

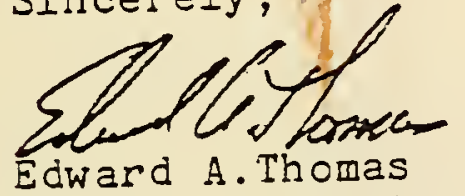

Edward A.Thomas

Regional Director

Federal Insurance Administration 
BOSTON REDEVEL LibraIY 


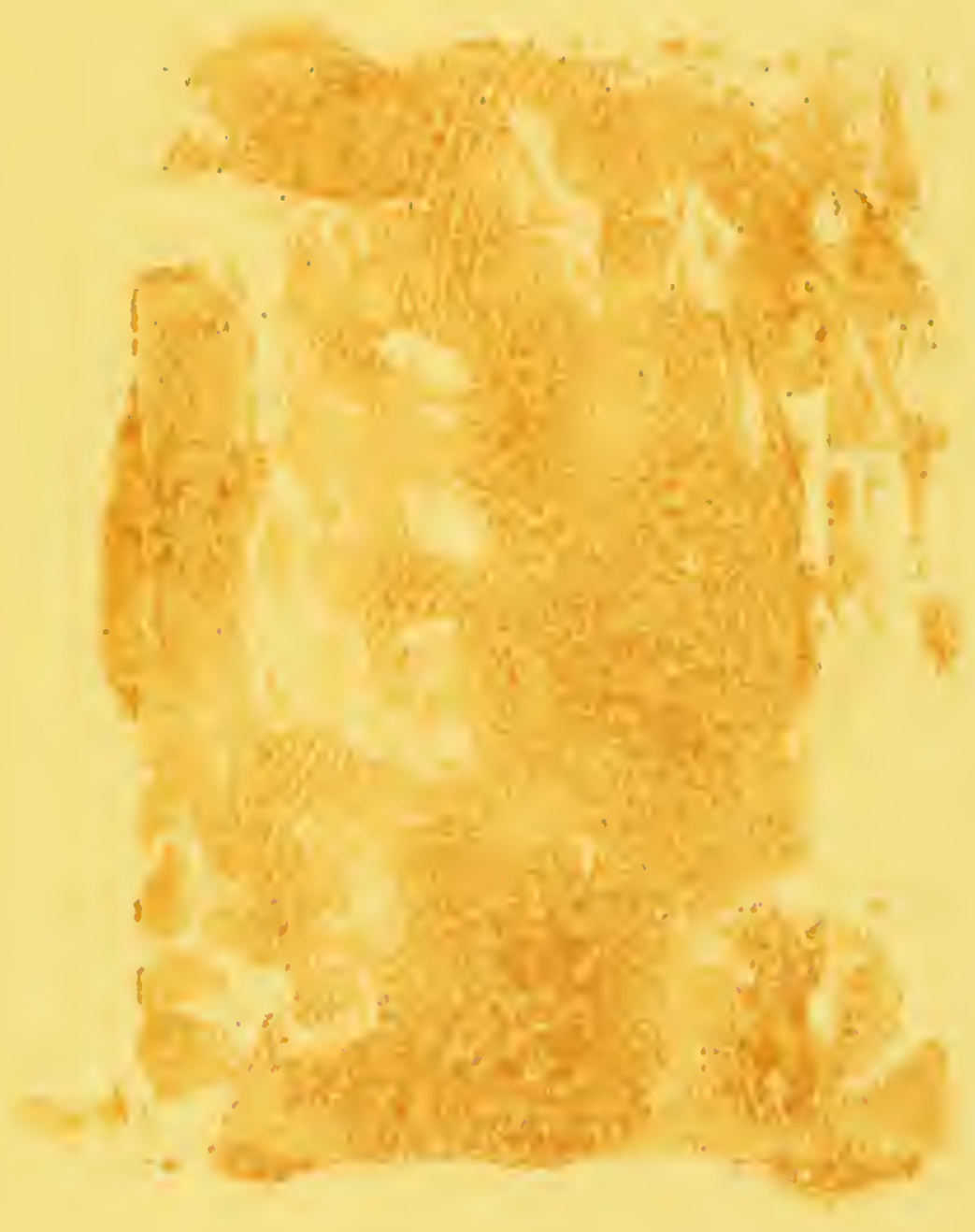

, $053 \quad 18$ 


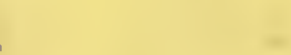





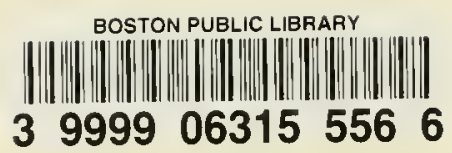



(3)

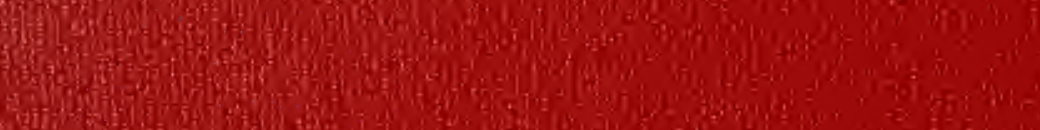
H. 364 . ches How

(4) 4. (6)

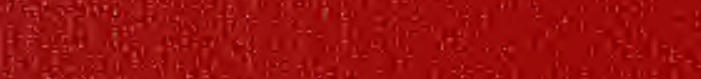

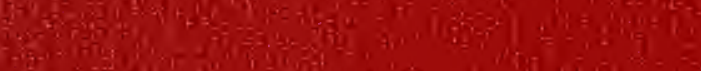
19. is a

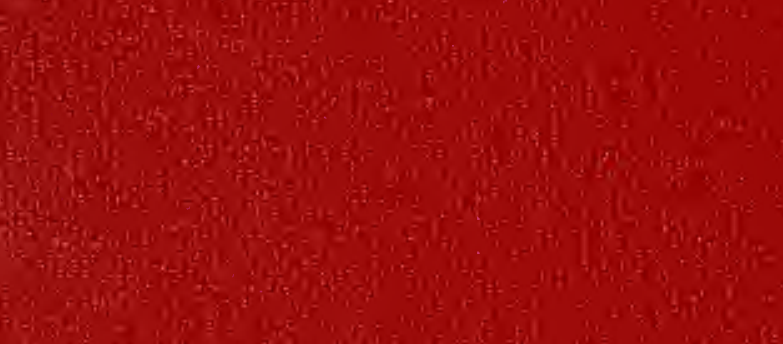

Hige

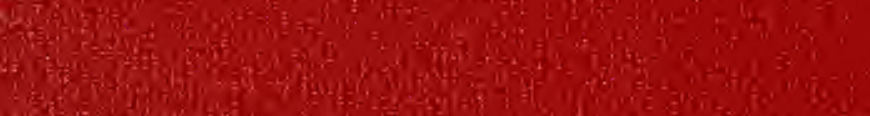

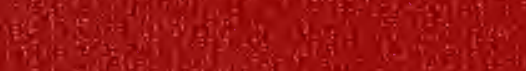
(1) 6. 1. W (5) W 